\author{
Tânia Pantano
}

Orientador: Prof. Dr. Mauro Rodrigues Penteado

\title{
OS LIMITES DA INTERVENÇÃO JUDICIAL NA ADMINISTRAÇÃO DAS SOCIEDADES POR AÇÕES
}

Tese apresentada à banca examinadora da Faculdade de Direito do Largo São Francisco, da Universidade de São Paulo, como exigência parcial para obtenção do título de Doutor.

Área de Concentração: Direito Comercial

Faculdade de Direito do Largo São Francisco

Universidade de São Paulo

São Paulo, 2009 
ÍNDICE

I - Introdução ......................................................................................................... 3

II - A legislação societária como legislação "incompleta"....................................... 31

II.1 - O contrato social como contrato "incompleto"...................................... 54

III - Os diversos interesses envolvidos na

administração das S.A............................................................................................... 61

III.1. -Interesses internos ........................................................................................... 66

III.2. -Interesses externos....................................................................................... 79

III.3. - Interesses sociais ........................................................................................ 90

IV - A intervenção judicial na administração das S.A.............................................. 99

IV.1 - Conflito de interesses ............................................................................127

IV.2 - Abuso do direito de voto.................................................................................135

IV.3 - Abuso do poder de controle .........................................................................141

IV.4 - Inobservância dos deveres dos administradores.....................................156

IV.5 - A regra de julgamento do negócio ("business judgment rule") .........164

IV.6 - Inobservância dos requisitos formais de convocação, realização e publicidade das assembléias gerais ................................................175

IV.7 - Arbitragem ........................................................................................................185

V - Considerações Finais ........................................................................................187

Bibliografia ...............................................................................................................................195 


\section{I - INTRODUÇÃO}

O trabalho ora apresentado tem por objetivo analisar os princípios que estabelecem limites a serem observados pelo Poder Judiciário, na análise de controvérsias versando sobre a administração das Sociedades por Ações.

Diversas situações podem ocorrer durante a existência de uma companhia, que levam os acionistas minoritários e terceiros interessados, afetados pelas atividades dessa companhia, a buscar, por intermédio do Judiciário, uma solução para uma controvérsia já existente ou evitar a ocorrência de situação que pode se tornar prejudicial a seus interesses ou aos próprios interesses da companhia, decorrentes de decisões e atos praticados pelo acionista controlador ou grupo de controle da companhia, que são os administradores de fato da companhia ${ }^{1}$ ou ainda pelos administradores.

Um dos problemas que precisam ser considerados, nessas situações, pelo legislador e pelo Judiciário, é a forma de promover o equilíbrio entre o exercício dos direitos dos minoritários e de terceiros e sua atuação junto aos órgãos de administração, para que esses direitos sejam exercidos sempre no interesse da sociedade e com boa-fé, e que não sejam ultrapassados os limites que levem ao abuso desses direitos, que prejudicam, acima de tudo, a própria companhia.

A observação das decisões judiciais proferidas pelos tribunais brasileiros nesses casos e a existência de um número muito baixo de ações envolvendo essa área do Direito Societário $^{2}$, leva à conclusão de que as partes envolvidas na

\footnotetext{
${ }^{1}$ LAMY FILHO, Alfredo e PEREIRA, José Luiz Bulhões. A lei das S.A.. $3^{a}$ edição. Rio de Janeiro: Renovar, 1997, vol. 1.

2 PRADO, Viviane Muller, BURANELLI, Vinícius Correa. Relatório da pesquisa de jurisprudência sobre Direito Societário e mercado de capitais no Tribunal de justiça de São Paulo (Relatórios de Pesquisa). São Paulo: Cadernos Direito GV, $\mathrm{n}^{\circ}$ 9, janeiro de 2006. Disponível em <http://www.direitogv.com.br/interna. aspx?PagId=HTKCNKWI\&IDCategory=4\&IDSubCategory=68>, acesso em 25.jan.2008.O resultado da pesquisa realizada pelos autores, com relação aos processos envolvendo direito societário, no Tribunal de Justiça do Estado de São Paulo e no Superior Tribunal de
} 
existência e funcionamento das sociedades, têm evitado socorrer-se do Judiciário para resolver as controvérsias surgidas entre eles.

Os profissionais que atuam nessa área atribuem essa situação aos seguintes fatores principais ${ }^{3}$ : (a) a falta de especialização dos juízes e Tribunais ${ }^{4}$ para lidar com os assuntos envolvendo Direito Societário gera insegurança quanto ao conteúdo das decisões que serão proferidas; e (b) o longo tempo de tramitação dos

Justiça, apontou a existência de apenas 50 casos, em que as partes discutiam questões sobre responsabilidade dos administradores ou do acionista controlador, pagamento de dividendos, direito de recesso e valor de valores mobiliários, exibição de documentos, prestação de contas, direito de voto, indicação de membros dos Conselhos de Administração e Fiscal e instalação deste último, fechamento de capital, diluição injustificada de capital, direito de preferência e procedimentos para realização de assembléias e tomada de decisões pelos administradores.

${ }^{3}$ Neste sentido, PRADO, Viviane Muller e BURANELLI, Vinícius Correa, Relatório da Pesquisa...., pág. 4.

${ }^{4}$ A criação de varas especializadas depende do Tribunal de cada Estado. O Estado do Rio de Janeiro, por exemplo, criou em 2001 varas especializadas em Direito Empresarial, através da ampliação da competência das Varas de Falência. Trata-se, na verdade, de um retorno às origens do próprio Direito Comercial, em que as regras eram aplicadas exclusivamente aos comerciantes, que possuíam Tribunais próprios, formados por pessoas envolvidas com o tráfico comercial e que possuíam a expertise necessária para lidar com as características dessa área do Direito e, portanto, poderiam alcançar soluções mais eficazes às controvérsias envolvendo os comerciantes e as relações comerciais. Em entrevista concedida em 03.11.2008, ao Espaço Jurídico BM\&FBovespa (disponível em http://www.bovespa.com.br/Investidor/Juridico/081103NotA.asp), acesso em 21.01.2009, a ex-Diretora da CVM, Norma Jonssem Parente, que participou dos estudos para criação dessas varas especializadas no Estado do Rio de Janeiro, assim avalia o resultado dessa medida: "Hoje, com uma experiência mais consolidada, qual a sua avaliação sobre as Varas Empresariais do Rio de Janeiro? — Para a Economia é muito importante ter um Judiciário eficiente que dê maior segurança às relações e aos participantes do mercado. Ter uma Justiça rápida e atenta para resolver os conflitos dessa área é fundamental para a efetividade da proteção dos direitos das partes envolvidas. Daí as Varas Empresariais se apresentarem como uma garantia não só para os diretamente envolvidos, mas para a sociedade como um todo. Mas de forma prática, como essa especialização ajuda ao Judiciário? - As varas cíveis, principalmente as das capitais, são muito assoberbadas, com questões que não têm um grau de complexidade muito grande, relacionadas a conflitos particulares do cotidiano, que se misturam a discussões mais complexas de aspecto econômico. Esse quadro pode levar o juiz a ter mais dificuldades para enfrentar aquele problema que envolve matérias que são vistas com pouca freqüência, exigem um conhecimento mais específico, mas que, muitas vezes, têm um impacto significativo para a sociedade. Com a especialização, o juiz passa a analisar esse tipo de matéria em seu dia a dia, e o que seria um caso isolado se transforma em mais um dentro daquele seu campo de trabalho habitual, em sua rotina. A percepção dessas questões é mais rápida e eficiente, pois ele está focado e melhor informado nessa área." Também em entrevista concedida em 02.10.2008 ao mesmo espaço (disponível em http://www.bovespa.com.br/Investidor/Juridico/081002NotA.asp), acesso em 21.01.2009, o juiz Marcelo Fortes Barbosa Filho, na $4^{\mathrm{a}}$ Vara Cível do Fórum Central de São Paulo, especializado em Direito Empresarial, comenta a conveniência da criação de varas especializadas em Direito Empresarial no Estado de São Paulo: "E no caso da Justiça Paulista, seria interessante a criação de Varas Empresariais? - Hoje no foro central temos 42 varas, com 84 juízes. Para os juízes, mesmo com a diversidade de assuntos _ de locação à conflitos em Sociedades Anônimas _ não é ruim. O Tribunal de Justiça já cogitou essa possibilidade. A Lei de Organização Judiciária de 2005 criou as varas especializadas em recuperações e falências. Mas é necessário um certo cuidado porque não dá para se ater somente a uma questão de números, de volume. Esses processos não são iguais, são mais trabalhosos, complexos. Há o risco de criar uma vara empresarial e o juiz ficar mais assoberbado porque os seus processos terão uma qualidade mais complexa. Pode criar um embaraço ao invés de criar uma válvula de escape." 
processos nos tribunais brasileiros, que mantém a companhia, seus acionistas e terceiros envolvidos inseguros quanto à definição da situação controvertida, até obtenção do trânsito em julgado de sentença definitiva o que acarreta ainda mais prejuízos às partes envolvidos 5 .

De fato, ao se observar o conteúdo dos acórdãos proferidos por nossos tribunais, verificamos que as decisões nem sempre oferecem uma solução adequada e eficaz à situação apresentada, o que decorre principalmente da desconsideração dos interesses e princípios empresariais envolvidos. Como bem ressaltou Osmar Brina Corrêa-Lima ${ }^{6}$, a legislação que trata das sociedades por ações contém alguns preceitos e expressões que podem desafiar sua correta interpretação, outorgando o legislador, ao Judiciário, um voto de confiança que “...requer uma atuação lúcida, eficiente e corajosa daquele poder [Judiciário].”

A atuação judicial no âmbito da administração das sociedades por ações, deve sempre considerar a liberdade do empresário em determinar os rumos e a orientação geral dos negócios da companhia, garantida pela Constituição Federal de 1988, inciso IV do art. $2^{\circ}$, nos incisos XVII, XVIII e XXII, do art. $5^{\circ}$, e no art. 170 , o qual estabelece ainda o princípio da função social das sociedades em geral, de observância obrigatória dos acionistas controladores e administradores de sociedades.

Desta forma, considerando a liberdade de contratar conferida aos acionistas $^{7}$ no exercício da iniciativa empresarial, se os atos constitutivos e o Estatuto Social não contiverem disposições contrárias à Lei das S.A. (art. 83) e estiverem dentro dos parâmetros e procedimentos que conferem legalidade e validade na forma da legislação em vigor, a companhia terá personalidade jurídica e patrimônio próprios e os termos de seu Estatuto valem perante terceiros e serão de observância

\footnotetext{
${ }^{5}$ A pesquisa realizada por PRADO, Viviane Muller e BURANELLI, Vinícius Correa, objeto do Relatório da Pesquisa de Jurisprudência sobre Direito Societário e Mercado de Capitais no Tribunal de Justiça de São Paulo, considerou o tempo decorrido entre o ajuizamento da ação, em primeira instância, até seu julgamento em segunda instância. Foi apurado que o tempo médio de tramitação de ações versando sobre Direito Societário é de 1.536,80 dias (aproximadamente 4 anos e meio), sendo o tempo mínimo de 233 dias e o máximo de 3.993 dias (mais de 10 anos).

${ }^{6}$ Sociedade Anônima, $2^{a}$ Edição. Belo Horizonte: Del Rey, 2003, pág. 475.

${ }^{7}$ Conforme inciso XVI do artigo $5^{\circ}$ e parágrafo único do artigo 170 da Constituição Federal e artigos 421 e 422 do Código Civil.
} 
obrigatória de todos os acionistas (os fundadores e os que nela ingressarem posteriormente) (arts. 94, 97, 98 e $\S 1^{\circ}$ do art. 135).

A gestão da companhia e o exercício de suas atividades devem ser realizados dentro dos limites do objeto social fixado no Estatuto e sempre visando imediatamente os interesses da sociedade e, mediatamente, o objetivo final dos acionistas que é a apuração e distribuição dos lucros, através da realização das atividades relacionadas ao objeto social, observando-se ainda os interesses institucionais relacionados à existência da sociedade e seu impacto na economia e na coletividade em que atua.

Assim, podem e devem os empreendedores usufruir da liberdade de exercer a atividade econômica a que se propuseram, mas essa liberdade encontra limites nos demais interesses envolvidos na existência da companhia, interesses esses que podem se encontrar dentro ou fora da própria companhia, e que envolvem os acionistas minoritários, os empregados da companhia, a comunidade em que ela atua, e até mesmo, o interesse público ${ }^{8}$.

Para se determinar os interesses relevantes envolvidos na condução de negócios de uma companhia, deve-se considerar que as sociedades por ações, como as sociedades em geral, são constituídas através de contratos plurilaterais, e que, desta forma, existe a necessidade de harmonização dos interesses dos acionistas e a obrigação de colaboração entre si, para que a companhia possa ser constituída e funcionar em harmonia. Certamente esses interesses, antes da formação da sociedade, podem ser (e normalmente são) antagônicos e divergentes, mas é a convergência dos interesses dos acionistas, a aceitação dos riscos econômicos envolvidos no investimento por eles realizado e o dever de colaboração (que configura a affectio societatis), que irá

\footnotetext{
${ }^{8}$ Como ressaltaram os autores do projeto da Lei das S.A., Alfredo Lamy Filho e José Luiz Bulhões Pedreira, em A Lei das S.A.... pág. 197: "O Anteprojeto não elege nem exclui nenhum tipo de organização das companhias, nem tenta impor-lhes esse ou aquele modelo. Companhias pequenas, médias ou grandes, institucionalizadas ou não, poderão nascer, existir e crescer nos quadros do Anteprojeto, porque têm uma função a desempenhar na economia aberta. Mas todos os que de sua direção ou administração - acionistas controladores, administradores profissionais, tecnocratas, maioria ou minoria na assembléia geral, brasileiros, estrangeiros ou multinacionais - estarão sujeitos ao mesmo regime, que só admite o exercício do poder nos limites e para os fins previstos na lei, e que lhes cobra a responsabilidade social que constitui a contrapartida necessária do poder."
} 
caracterizar o contrato de sociedade e o funcionamento regular e existência produtiva e lucrativa da empresa.

A affectio societatis é um dos elementos distintivos dos contratos societários e está sempre presente, em maior ou menor grau, em todas as sociedades, sendo essencial para sua existência. J.X. Carvalho de Mendonça ${ }^{9}$, resume essa característica em uma identidade de interesses, que requer cooperação econômica e vontade de colaboração ativa, conforme expressões utilizadas por Rippert e Thaller, "sempre visando o fim comum, a realização de um enriquecimento pelo concurso dos seus capitais e da sua atividade."

A colaboração entre os sócios para alcançar esse objetivo comum é fundamental para permitir a constituição e existência das sociedades. No caso das sociedades por ações, pode-se constatar diferentes graus de affectio societatis entre os sócios, conforme o relacionamento, interesses e expectativas dos acionistas entre si, com a sociedade e sua natureza, se aberta ou fechada ${ }^{10}$.

Após a constituição da companhia, esta passa a ter patrimônio autônomo e personalidade jurídica própria, distinta de seus sócios. Os interesses dos acionistas organizam-se dentro das regras previstas no Estatuto e deverão permanecer voltados, todos, para a finalidade comum que é a manutenção da existência da companhia, através da realização do objeto social e, em última instância, a obtenção de lucros a serem repartidos entre os sócios ${ }^{11}$.

\footnotetext{
${ }^{9}$ Em Tratado de Direito Comercial Brasileiro, volume III. Revista por Achilles Bevilaqua e Roberto Carvalho de Mendonça. 2a edição. Rio de Janeiro: Livraria Editora Freitas Bastos, 1933, pág. 23: "Melhor e mais exato será dizer que os sócios devem manifestar a vontade de cooperar ativamente para o resultado que procuram obter, reunindo capitais e colocando-se na mesma situação de igualdade. É indispensável à sociedade a identidade de interesses, a cooperação econômica, na frase de Rippert, ou a vontade da colaboração ativa dos sócios, na expressão de Thaller, tendo estes sempre em vista o fim comum, a realização de um enriquecimento pelo concurso dos seus capitais e da sua atividade. Muito bem explicava o nosso João Monteiro, que 'na colaboração está a idéia visceral de toda a sociedade'."

${ }^{10}$ A Lei das S.A. possibilita a existência de companhias abertas e fechadas, com maior ou menor grau de preponderância da affectio societatis, como ressaltou LAMY FILHO, Alfredo, em A Reforma da Lei das Sociedades Anônimas, RDM, vol. 7, Ano XV, Nova Série, 1972, pág. 125: “Com efeito, entre a S/A fechada - mera técnica de estruturar um negócio, que poderia eventualmente revestir qualquer outra forma societária - e a S/A aberta - cujos títulos alimentam o mercado de capitais, que apela para o público em busca do capital de risco de que necessita (como vai à rede bancária obter o financiamento em capital empréstimo), - a diferença não é apenas de tamanho ou de grau, é de natureza."

${ }^{11}$ ASCARELLI, Tullio, em Studi in Tema di Contratti. Milano: Dott. A. Giuffrè Editore. 1952, pág. 152: "...il contratto mira ad organizzare, in relazione ad uno scopo comune, una preesistente comunioni d'interessi, disciplinando in sostanza una formazione di categoria."
} 
No entanto, a constatação de que são os interesses dos sócios que possibilitam a constituição da sociedade não permite concluir que o interesse desta se confunde com o de seus sócios. A sociedade passa a constituir um ente autônomo, titular de direitos, obrigações e patrimônio próprios, distinto dos sócios que a compõem e que assume direitos e obrigações com terceiros. Na realização de sua atividade econômica, protegida por dispositivos constitucionais, o Estado também reconhece limites ao exercício dessa atividade e aos interesses dos sócios, limites estes que resguardam interesses que o Estado protege por sua relevância e em atendimento a valores econômicos e sociais também protegidos pela Constituição Federal e que estão contidos na expressão "função social".

Assim, os interesses e direitos particulares dos acionistas e da companhia encontram limites em princípios institucionais que visam garantir a preservação da empresa e que reconhecem diversos interesses públicos como limitadores do exercício irrestrito de tutela dos interesses e direitos dos sócios, como ensina Modesto Carvalhosa ${ }^{12}$ : "Constituída em virtude de um contrato privado, a companhia, na medida em que atua no meio social como forma de organização jurídica da empresa, acaba por ser considerada uma instituição de interesse público, levando inclusive à ingerência do Estado nos atos de sua formação e atuação."

As características institucionais das sociedades anônimas estão refletidas na definição legal dos direitos e deveres dos sócios, principalmente dos controladores, na forma de seu exercício e nas restrições a esses direitos e deveres. A Lei 6.404 também elege os princípios gerais de preservação da companhia e o atendimento à sua função social, como princípios fundamentais. Tais elementos são considerados fundamentais, e sua observância obrigatória, principalmente no caso de grandes empresas, cuja existência e consecução de atividades possuem grande relevância na economia em geral, enquanto geradoras de tributos e empregos, atuantes do mercado de capitais, adquirentes e fornecedoras de bens e serviços.

\footnotetext{
${ }^{12}$ Comentários à Lei de Sociedades Anônimas, $2^{\text {a }}$ edição. São Paulo: Saraiva, 1998, volume 1, pág. 7.
} 
Por essas razões, os interesses públicos e de terceiros possuem um peso importante na condução dos negócios das companhias, sendo também considerados em seu âmbito interno e no exercício do poder de controle. Tais interesses externos podem, em algumas situações, prevalecer sobre os interesses internos de seus sócios, haja vista a importância da manutenção da produtividade do capital, especialmente em determinados setores estratégicos para a economia.

Nesse sentido, o legislador brasileiro especificou, na Constituição Federal, os interesses e valores públicos, sociais e econômicos, protegidos pelo Estado Brasileiro e relacionados à realização da atividade empresarial, conforme previsto no artigo $1^{\circ}$, incisos III e IV, no artigo $3^{\circ}$, incisos I, II e III e no artigo 219 da Constituição Federal, e estão resumidos, principalmente, no artigo 170, do Capítulo I, do Título VII, que trata "Dos Princípios Gerais da Atividade Econômica”.

Os valores consagrados nos dispositivos acima referidos são determinantes dos limites e deveres atribuídos aos empresários no desenvolvimento de suas atividades e na utilização dos meios de produção, não apenas para obtenção de lucros e atendimento de interesses pessoais, mas também para o desenvolvimento econômico e social, como destaca Eduardo Secchi Munhoz ${ }^{13}$.

Assim, em caso de colisão de interesses dos sócios ou da sociedade, com os interesses públicos, que representam valores protegidos pela Constituição Federal e servem de base para a manutenção do princípios sociais e econômicos de interesse geral, o Judiciário deverá sopesar os interesses envolvidos e aplicar os princípios que estruturam o sistema jurídico Brasileiro, de acordo com o grau de importância dos interesses tutelados pela ordem jurídica.

Em reforço a esta posição, o aspecto institucional das sociedades por ações está contemplado em diversos dispositivos da Lei das S.A., principalmente no parágrafo único do artigo 116 da Lei 6.404, de 15 de dezembro de 1976, o qual

13 Empresa Contemporânea e Direito Societário, São Paulo: Juarez de Oliveira, 2002, pág. 30: "Apreendida a propriedade em seu aspecto dinâmico e funcional, a lei societária deve reconhecer ao empresário um poder funcional (direito-função), no sentido de que é atribuído ao titular, não para atender aos seus interesses egoísticos pessoais, mas para a realização de uma finalidade precisa, no caso, não apenas a produção de lucros, mas o desenvolvimento econômico e social, idéia que está imanente nos valores enunciados pela Constituição Federal, antes referidos." 
estabelece: "O acionista controlador deve usar o poder com o fim de fazer a companhia realizar o seu objeto e cumprir sua função social, e tem deveres e responsabilidades para com os demais acionistas da empresa, os que nela trabalham e para com a comunidade em que atua, cujos direitos e interesses deve lealmente respeitar e atender."

A evolução das teorias contratual e institucional que analisam e explicam os diferentes aspectos e interesses, internos e externos, envolvidos na constituição e funcionamento dos tipos societários existentes, levou ao reconhecimento de que, independentemente da predominância de uma ou outra teoria, vários aspectos considerados por ambas as teorias merecem proteção por sua importância para o sistema jurídico e econômico em geral.

Além disso, outras áreas das ciências humanas, tais como a sociologia, ciência política, economia e antropologia influenciaram tais teorias e serviram para adaptá-las às mudanças econômicas, sociais e políticas ocorridas nos últimos anos.

Desta forma, diversos princípios utilizados para análise de fenômenos econômicos, por exemplo, vêm sendo utilizados para análise de situações jurídicas, para valoração e criação de regras jurídicas positivas, e para análise da construção jurisprudencial, para identificar soluções que melhor se adaptem às necessidades atuais, constituindo um novo ramo de exploração interdisciplinar, como já ocorre nos Estados Unidos com a disciplina "Law and Economics", que exerce influência na doutrina de outros países, inclusive no Brasil ${ }^{15}$.

Cinzia Gamba ${ }^{16}$ reporta o desenvolvimento, na Itália, da "nova economia institucional" ou nova economia política, como resultado da fusão de diversos

${ }^{14}$ SALOMÃO FILHO, Calixto. O Novo Direito Societário. $2^{\mathrm{a}}$ Edição. São Paulo: Malheiros Editores Ltda., 2002, pág. 37, questiona a utilidade dessa regra genérica: "Procurou-se criar um sistema de proteção das minorias acionárias, baseado, entre outras coisas, na institucionalização dos poderes e deveres do sócio controlador e dos administradores. Manifestação dessa tendência é o art. 116, parágrafo único, que estabelece deveres genéricos para o acionista controlador com relação aos demais acionistas da empresa, aos trabalhadores e à comunidade em que atua. Sobre a utilidade desse tipo de declaração genérica, que não encontra tradução em regras organizativas, existem muitas dúvidas. Pode-se questionar se não acaba servindo, como ocorreu na Alemanha, para justificar atuações dos acionistas majoritários e seus representantes no interesse próprio, em nome de um maldefinido interesse social."

${ }^{15}$ GAMBA, Cinzia, Diritto Societário e Ruolo del Giudice. Padova: CEDAM, 2008, pág. 9.

${ }^{16}$ Diritto Societario ..., pág. 7. 
elementos trazidos pelas ciências econômica, jurídica e sociológica, dentre outras, servindo de método de análise interdisciplinar e utilizando linguagem e métodos predominantemente econômicos. Essa teoria teve origem a partir dos ensinamentos de Coase a respeito da natureza da empresa e de suas análises econômicas sobre a propriedade individual. O objetivo da "nova economia institucional" é explicar o significado das instituições políticas, econômicas e sociais ${ }^{17}$ que determinam "as regras do jogo" no campo econômico e empresarial, sua constituição e evolução por um período de tempo, seus objetivos e as formas de existência e de persecução de suas finalidades individuais, possibilitando sugestões de reformas das instituições existentes.

Essa teoria tem por um dos temas principais, a análise do surgimento e da natureza das formas organizadas de coordenação social, interpretadas a partir das escolhas dos indivíduos, considerando que, do ponto de vista econômico, não existe forma de organização isenta de custos, as formas mais eficazes e racionais para existência dessas organizações serão determinadas pelos custos envolvidos ${ }^{18}$.

Sob a perspectiva da análise econômica do direito, Cinzia Gamba pondera que a existência e funcionamento de uma pessoa jurídica privada, com objetivos econômicos particulares, exige do Estado um papel de regulamentação e proteção de suas atividades que, se não realizado de modo adequado, oferece riscos para a tutela da atividade econômica, podendo, até mesmo, frustrar os objetivos para os quais a pessoa jurídica é criada. Para isso, devem ser considerados não apenas os interesses

\footnotetext{
17 A teoria utiliza o termo "instituições" em sentido amplo, incluindo “...as organizações e estruturas privadas, tais como Bolsa de Valores e registro de valores mobiliários, estruturas públicas organizacionais regulatórias do mercado de capitais, tribunais com experiência em Direito Comercial, força policial honesta, um sistema de correios confiável, sociedades de economia mista que criem estruturas autoregulatórias, organizações contábeis e regras de contabilidade financeira sofisticadas”, conforme BLACK, Bernard e KRAAKMAN, Reinier, A Self-Enforcing Model of Corporate Law, pág. 01.

${ }^{18}$ GAMBA, Cinzia, Diritto Societario..., pág. 7: "La 'nuova economia istituzionale' o nuova economia política è una costruzione teorica interdisciplinare nella quale sono fusi elementi di economia, diritto, teoria dell'organizzazione, scienze politiche, sociologia e antropologia. Essa si propone come un metodo di analisi interdisciplinare, che attinge liberalmente dai diversi campi scientifici cui afferisce, utilizzando linguaggio e metodi prevalentemente di carattere economico. In generale, lo scopo della nuova economia istituzionale è quello di spiegare che cosa siano le 'istituizoni' (politiche, economiche e sociali) intese come 'regole del gioco', la loro nascita e la loro evoluzione nel corso del tempo, gli scopi cui servono, le modalità con cui la loro esistenza contrasta o si accorda con il perseguimento delle finalità individuali e, soppratutto, in chiave normativa, le possibilità di indirizzare in modo 'razionale' le riforme degli assetti istituzionale esistenti. In generale, i temi principali trattati dalla teoria in esame riguardano l'emergere e la natura delle forme organizzate di coordinamento sociale, interpretate a partire dalle scelte individuali dei singoli e muovendo dall'ipotesi che non esistano forme di organizzazione sociale prive di costi."
} 
particulares dos sócios que participam da empresa em particular, mas também a "eficiência do sistema econômico em seu conjunto"19.

Nesse sentido, a ausência de instrumentos de tutela adequados ou a ineficácia ou dificuldades em sua aplicação, repercutem negativamente sobre a credibilidade do sistema, diminuindo a confiança na proteção dos agentes envolvidos e na aplicação das regras existentes, com repercussões negativas para o desenvolvimento da atividade econômica e empresarial ${ }^{20}$.

Sob esta perspectiva e especialmente no Direito Societário, o papel do Judiciário assume especial relevo como intérprete final da legislação existente cabendo-lhe a função de interpretar os princípios dessa área do direito para solução de controvérsias empresariais $^{21}$. Nesses casos, especialmente quando as normas existentes não prevêem expressamente essa situação de forma explícita, o Direito Societário estabelece os princípios gerais que regem o ambiente empresarial e, surgindo uma controvérsia, cabe ao Judiciário interpretar esses princípios e aplicá-los ao caso concreto.

Visando conciliar os interesses internos de todos os sócios, controladores e minoritários, da sociedade e dos terceiros envolvidos na atividade social e encontrar soluções satisfatórias para os conflitos daí surgidos, foram desenvolvidos, pela doutrina e jurisprudência, mecanismos de proteção aos interesses relevantes ao sistema jurídico. Alguns desses instrumentos foram incorporados à legislação, tais como o estabelecimento de padrões de conduta em que se enquadram os deveres e responsabilidades dos sócios controladores e administradores na condução dos negócios sociais, como determinam os artigos 116 e 117, e 153 a 159 da Lei das S.A. e a

${ }^{19}$ GAMBA, Cinzia. Diritto Societario..., pág. 10: "Ad essere in gioco, infatti, non sono soltanto gli interessi dei soggetti che partecipano all'impresa societaria bensì l'efficienza del sistema nel suo complesso: l'assenza di strumenti di tutela adeguati si ripercuote pesantemente sulla credibilità dei sistema e sulla fidúcia ispirata dalle sue regole, due motori importantissimi per lo sviluppo dell'attività economica ed imprenditoriale."

${ }^{20}$ GAMBA, Cinzia, Diritto Societario..., pág. 10.

21 Nos Capítulos II e III iremos analisar, sob a perspectiva da análise econômica do direito, a impossibilidade de determinação prévia, tanto na legislação como nos contratos de sociedade, de todos os comportamentos e controvérsias decorrentes da atividade empresarial e o papel que o Judiciário deve assumir para oferecer soluções adequadas e que diminuam os custos empresariais envolvidos na realização de suas atividades. 
possibilidade de desconsideração da personalidade jurídica, constante do art. 50 do Código Civil.

Nessa análise e em se tratando das sociedades por ações, deve-se considerar que este é o tipo societário mais utilizado pelas grandes sociedades e tem seu uso amplamente disseminado, justamente em razão dos princípios que regem esse tipo de sociedade, principalmente a limitação da responsabilidade de seus sócios e a capacidade de captação de recursos no mercado de capitais, que leva à participação popular na capitalização das empresas para realização das atividades que exigem uma grande mobilização de valores.

Como bem ressaltou William T. Allen ${ }^{22}$, que ocupou, durante 12 anos, o cargo de Juiz da Court of Chancery de Delaware, é o investimento privado e o desenvolvimento dos mercados, através da utilização de diversos tipos societários, especialmente as sociedades por ações de capital aberto que possibilitaram a grande maioria das descobertas científicas e tecnológicas que utilizamos atualmente e que revolucionaram nossa forma de viver, tornando nossas vidas mais "seguras, saudáveis, fáceis e agradáveis". O aumento da produtividade e as inovações decorrentes das pesquisas e investimentos realizados pelas sociedades são essenciais para manutenção da competitividade econômica e, de forma reflexa, para o desenvolvimento econômico e social de um país, justificando assim a criação de regras, práticas e técnicas econômicas que servirão de incentivo mas possibilitarão, ao mesmo tempo, controle do comportamento das pessoas que atuam nessa área.

A ampliação da utilização das sociedades por ações, ligado ao crescimento e globalização dos mercados de capitais levou os juristas de cada país a estudar e, por vezes, adotar as soluções, doutrinárias, legislativas e jurisprudenciais

\footnotetext{
${ }^{22}$ Modern Corporate Governance and the Erosion of the Business Judgment Rule in Delaware Corporate Law, Toronto: Law Research Paper Series, Osgood Hall Law School, York University. Disponível em: <http://ssrn.com/abstractid=1105591 >. Acesso em 01.dez.2008. pág. 1: "From railroads to automobiles and airplanes, from aspirin to immuno-suppresssants, from electricity, telephony, and computers, to the internet, WiFi and almost everything else that makes our lives safer, healthier, easier and more pleasant all are produced and distributed by people organized within the publicly financed corporate form. The legal rules and practices and the economic techniques we deploy to incentive and control the various individuals playing roles within these institutions matters to their efficiency and thus matters to our wealth production. (...) Certainly a great deal else matters vitally to our public welfare, but the productivity and innovation that occurs within the business corporations is essential for our welfare."
} 
empregadas por outros países, uniformizando e desenvolvendo institutos relacionados a esse tipo societário, e ajudando a compreender as características e os interesses envolvidos em sua criação, gestão, funcionamento e dissolução, que necessitam de proteção e controle em razão do papel econômico que essas sociedades representam.

Quando se analisam os motivos pelos quais se utilizam as sociedades por ações para organização de capitais voltados à realização de empreendimentos, especialmente de grande porte, verifica-se que dois são os motivos principais: a separação patrimonial, que possibilita a preservação dos bens dos demais sócios, que destinam à realização do empreendimento apenas os ativos necessários e relacionados à realização das atividades sociais e a possibilidade dos sócios, titulares da maioria do capital social, exercerem o controle da sociedade, determinando os rumos de suas atividades.

Ambas as características indicadas acima beneficiam aqueles que decidem iniciar uma atividade empresarial; no entanto, o desvirtuamento dos objetivos para os quais foram desenvolvidos tais princípios, podem acarretar prejuízos, não apenas a seus acionistas mas também a terceiros, direta ou indiretamente afetados por sua existência.

Considerando que a estrutura de poder de controle de uma sociedade por ações permite a separação entre propriedade e poder de controle, a Lei 6.404, a exemplo de outras legislações, estabelece, no artigo 109, os direitos essenciais dos acionistas, independentemente do percentual de sua participação no capital da sociedade e que não podem ser afastados pelo Estatuto Social ou pela Assembléia Geral e nem ter, afastados ou restringidos, os meios, processos ou ações que a lei confere ao acionista para assegurar esses direitos.

Com o mesmo objetivo e a fim de possibilitar a proteção dos interesses de terceiros e dos acionistas, a Lei das S.A. estabelece no parágrafo único do artigo 116, os limites externos ao exercício do poder de controle. A lei possibilita, aos acionistas, especialmente das companhias de capital fechado, determinar, quando de sua constituição, outros parâmetros de conduta aplicáveis aos administradores e acionistas da companhia, complementares aos estabelecidos na lei, e como serão regulados e 
atendidos os interesses de cada um dos sócios, que, neste momento, estão alinhados e voltados para esse objetivo comum que é a constituição da sociedade.

É impossível, no entanto, especificar e regular, na lei ou no Estatuto Social, todas as hipóteses de conflito que poderão surgir envolvendo os interesses dos acionistas, a atuação dos administradores e controladores e os interesses externos, da comunidade e economia, principalmente, decorrentes das atividades da companhia; pode-se apenas estabelecer os parâmetros e os princípios que serão empregados na solução desses conflitos.

Com relação à conduta dos acionistas, a Lei das S.A. estabelece alguns desses princípios nos artigos 115, 116 e 117. No entanto, levando em consideração as características de cada sociedade, especialmente as diferenças entre as companhias de capital aberto e fechado e para que essas características sejam levadas em consideração no futuro, em caso de divergência, é importante que os acionistas determinem de forma complementar a esses dispositivos, situações específicas que poderão ensejar conflitos de interesses ou abuso do poder de controle procurando ainda, se possível, estabelecer as soluções a serem empregadas nesses casos.

Mas ainda que os acionistas ajam com cautela, sejam previdentes e bem assessorados, não será possível regular no Estatuto Social ou no Acordo de Acionistas, de forma exaustiva, todas as situações que poderão ocorrer, tendo em vista o caráter dinâmico da situação dos sócios e a imprevisibilidade de seu comportamento, o ingresso de novos sócios e alterações inesperadas na situação econômica do país ou do setor em que a empresa atua que afetam diretamente seu funcionamento.

Por este motivo e pela própria natureza dinâmica das relações em que a companhia tomará parte ou influenciará, sob este aspecto, o contrato de sociedade pode ser considerado um contrato "incompleto", como será exposto adiante, na medida em que, ao contrário de outros tipos de contratos que estabelecem, de forma exaustiva, as situações que poderão ocorrer no curso de sua execução e o tratamento a ser dado a cada uma delas, não é possível estabelecer, desde o início, todas as situações 
que envolverão a companhia, seus sócios e administradores na condução dos negócios sociais.

Neste panorama, verifica-se que, muitas vezes, a interferência judicial é necessária para assegurar a observância dos direitos individuais essenciais dos acionistas, sanar irregularidades e vícios existentes nos atos constitutivos da companhia, ou na convocação, instalação e realização das Assembléias Gerais, obrigando os controladores e acionistas a observar os limites ao exercício de seus poderes e direitos, evitando, assim, seu exercício abusivo.

A dificuldade de conciliação de todos esses interesses aos interesses da companhia, que podem, em determinados momentos, se tornar antagônicos, é ainda maior nas grandes empresas, como já alertava Alfredo Lamy Filho $^{23}$ : “O objetivo principal a alcançar - propiciar a formação e a gestão eficiente e responsável da grande empresa - requer decisões de várias ordens, e a escolha entre alternativas que, com maior ou menor sucesso, têm sido adotadas pelos legisladores ou defendidas pelos estudiosos. Efetivamente, o alvo a atingir supõe incentivo e estímulo ao investidor para aplicar poupanças no mercado de capitais de risco, e, para tanto, cabe reforçar-lhe os direitos, aumentar a publicidade dos atos dos administradores, defendêlo contra fraude dos gestores, tornar efetiva a posição do acionista como dono e controlador da empresa; correlatamente, cabe proteger a iniciativa do empresário, assegurar-lhe liberdade de ação para decisões que, inclusive, envolvem riscos inerentes à vida empresarial, dar-lhe meios de defender-se e defender a empresa da omissão e incompetência dos acionistas. Do mesmo passo, cabe propiciar à S/A o desempenho da função básica a serviço da atividade privada na realização de grandes empreendimentos, e zelar para que o poder e a força de que dispõe não sejam utilizados contrariamente ao bem público, dando-lhe uma consciência de responsabilidade social, que pode acabar por esterilizar o instrumento à força de publicizá-lo. É mister, por isso, buscar a dificílima linha de conciliação entre o interesse da empresa, cujo êxito deve ser assegurado, do acionista que deve ser protegido contra fraude, do gestor que precisa de liberdade para agir, do credor que faz jus à segurança de seu crédito, e do próprio

\footnotetext{
${ }^{23}$ A Reforma..., pág. 137.
} 
Estado, fiscal do interesse público em jogo. Os caminhos trilhados ou propostos para alcançar esse objetivo são vários, e, muitas vezes, opostos."

Assim, na proteção dos interesses públicos envolvidos na realização da atividade empresarial e dos interesses dos minoritários que se sintam prejudicados, deve o magistrado estar atento à necessidade de garantir ao empresário autonomia e liberdade na condução de seus negócios, voltados para a finalidade última que é a obtenção de lucros mediante realização do objeto social.

Para isso, a Lei das S.A. estabelece parâmetros para análise e avaliação das condições em que o acionista controlador exerce o poder de controle e para verificação da existência de interesses particulares que podem interferir no exercício desse poder, em prejuízo do interesse da companhia ou de seus sócios minoritários, através da indicação de situações de exercício abusivo do poder de controle ou do abuso do direito de voto ou ainda em caso de conflito de interesses, conforme artigos 115 e 117.

A função social a que deve o empresário se subordinar, nos termos do parágrafo único do art. 116, que tem por fundamento o inciso XXIII do art. $5^{\circ}$ da Constituição Federal, tem nuances diferentes daquela atendida pela propriedade e os contratos em geral, considerando a amplitude de indivíduos e interesses envolvidos.

Neste sentido, Fábio Konder Comparato ${ }^{24}$ distingue os reflexos da função social da propriedade, e da função social dos meios de produção: "Se se quiser lograr algum avanço na regulação constitucional da propriedade, é preciso estabelecer as distinções e precisões fundamentais. Algumas delas já foram mencionadas nesta exposição: a função social da propriedade não se confunde com as restrições legais ao uso e gozo dos bens próprios; em se tratando de bens de produção, o poder-dever do proprietário de dar à coisa uma destinação compatível com o interesse da coletividade transmuda-se, quando tais bens são incorporados a uma exploração empresarial, em poder-dever do titular do controle de dirigir a empresa para a realização dos interesses coletivos."

\footnotetext{
${ }^{24}$ Direito Empresarial - Estudos e Pareceres. São Paulo: Saraiva. 1990, pág. 34.
} 
Trata-se do enquadramento da titularidade da participação societária, em um conceito diferente de propriedade, conforme tese defendida por Adolf A. Berle e Gardiner C. Means ${ }^{25}$. A propriedade de ações ou quotas de uma sociedade constituiria a "propriedade produtiva - propriedade dedicada à produção, manufaturas, serviços ou comércio, com a finalidade de oferecer, por certo preço, bens ou serviços ao público, com os quais seu possuidor espera obter lucro.” E em razão do interesse social envolvido na administração das sociedades, os autores distinguem a forma de tratamento que um e outro tipo de propriedade recebem: "A propriedade dedicada a outros usos que não o comercial ou produtivo é tratada de outra maneira. Uma pessoa pode recusar-se a hospedar qualquer pessoa em sua casa ou permitir que alguém dirija o seu carro. O consumo de uso pessoal é uma expressão da personalidade, protegida contra a invasão. A propriedade (no sentido específico em que temos usado o termo) dedicada à produção não o é; nem no emprego do trabalho, nem na venda de bens e serviços pode o antigo direito absoluto de soberania da propriedade - poder de decisão, na fase atual - ser ilimitado. (...) O fato significativo é que a lei procura assegurar que a propriedade produtiva não seja usada para impedir a produção segundo as diretrizes do processo competitivo da forma concebida pela ciência econômica clássica e que se sujeite às suas condições."

A necessidade de atender à função social que a organização dos meios de produção cria para o empresário, traduz-se em uma obrigação de conduta ética do empresário, de respeitar interesses que, dependendo de sua origem, podem se revelar superiores ao seu próprio ou da sociedade. Esse interesse social orientador dos atos dos controladores e administradores de uma sociedade, abrange os interesses dos empregados, credores, fornecedores, consumidores, do meio ambiente e do próprio Estado $^{26}$.

$\mathrm{O}$ interesse social a que se subordinam as sociedades, seus administradores e os acionistas, nos dizeres de Maurice Cozian e Alain Viandier ${ }^{27}$, é a

${ }^{25}$ A Moderna Sociedade Anônima e a Propriedade Privada. São Paulo: Abril Cultural. 1984, pág. 06.

${ }^{26}$ Droit des Sociétés. 9a Edição. Paris: Libraire de la Cour de Cassation, 1996, pág. 176.

${ }^{27}$ Droit..., pág. 175: "L'intérêt social est la "boussole" qui indique la conduite à suivre et permet de détecter les déviations, notamment les abus de majorité ou de minorité. (...) C'est un impératif de 
bússola que orienta a conduta a ser seguida e permite detectar os desvios ocorridos, notadamente os abusos da maioria ou da minoria; sendo um imperativo de conduta, uma regra deontológica, mesmo moral, impondo o respeito a um interesse superior aos interesses pessoais.

É importante ressaltar, no entanto, que o conceito de função social defendido pelos legisladores e doutrinadores, como limitador da liberdade individual dos empresários, não está vinculado à realização de fins de interesse público, como entendia inicialmente a doutrina institucionalista, mas serve como limite externo à atuação da sociedade e seus administradores.

Luiz Gastão Paes de Barros Leães ${ }^{28}$ assim resume sua posição quanto a este tema: "Em atenção ao princípio da liberdade da iniciativa econômica (art. 157, inc. I da Constituição Federal de 1967) [correspondente ao art. 170 da atual Constituição Federal], o interesse público somente poderá impor-se à empresa privada como um limite externo à sua autonomia. Com efeito, dispondo a sociedade anônima de uma incontrastável natureza convencional, curial que reflita a evolução contemporânea do direito contratual, influenciado pela política solidarista e pelas normas de economia dirigida que envolvem os vários ramos de direito moderno. Essas restrições, porém, são de ordem externa, e refletem a atual situação sócio-econômica, mas não subverte a natureza contratual da sociedade a ponto de se conceber um interesse social superior e distinto dos interesses dos acionistas."

Considerando assim todos os interesses envolvidos na existência e funcionamento das sociedades por ações, podemos vislumbrar diversas situações que levam à intervenção judicial no âmbito interno das sociedades. A mais comum consiste na análise da regularidade e legalidade dos atos praticados pelos órgãos da administração, gestão e fiscalização das sociedades por ações (Assembléia Geral, Conselho de Administração, Diretoria e Conselho Fiscal) os quais, quando da ocorrência de desentendimentos graves entre seus integrantes, podem levar à sua paralisação e até mesmo impossibilidade de atingir os fins a que se destina a companhia.

conduite, une règle déontologique, voire morale, qui impose de respecter un intérêt supérieur à son intérêt personnel."

${ }_{28}^{28}$ Do Direito do Acionista ao Dividendo. São Paulo: Oficinas da Editora Obelisco, 1969, pág. 29. 
A paralisação dos órgãos sociais envolve situações nas quais os sócios e administradores da companhia não conseguem chegar a um consenso para tomar as decisões necessárias para o andamento dos negócios sociais, ocasionando prejuízos por vezes irreversíveis à sociedade e justificando a intervenção do Judiciário para solução do impasse e para possibilitar à companhia a continuidade de suas atividades.

Como dito anteriormente, numa situação de desentendimento e impasse entre os sócios, em que estes colocam seus interesses particulares acima dos interesses da companhia, deve o Judiciário levar em consideração os princípios envolvidos na atividade empresarial e que garantem autonomia de atuação ao controlador, dentro dos limites impostos por lei e pelo Estatuto. Neste sentido, o Ministro Sálvio de Figueiredo, no julgamento do Recurso Especial no 35.230-0/SP, de 20.11.1995: "Com efeito, a relação entre acionistas e sociedade, em razão das peculiaridades de que se reveste, exige tratamento diferenciado. A atividade empresarial, dada a dinâmica dos negócios que constituem a sua essência, realizados diuturnamente, envolvendo inúmeros compromissos e obrigações, requer, para que não reste ameaçada a sua viabilidade, uma certa estabilidade, uma situação definida que possibilite um mínimo de segurança na tomada de decisões. Ciente dessa realidade, o legislador pátrio atribuiu aos sócios prazos exíguos para impugnarem as deliberações assembleares, exatamente porque com esteio nelas é que atuam os órgãos diretores da empresa, internamente e nas relações contratuais com terceiros. Mesmo as deliberações contrárias aos ditames legais ou estatutários convalescem após o transcurso do lapso prescricional. E há uma razão para tanto. É que a deliberação encerra a vontade da maioria, sendo de pressupor-se que, não obstante infringente das disposições normativas, foi concebida por ser benéfica à sociedade e, de forma indireta e reflexa, também aos sócios."

Também como proteção aos interesses dos acionistas, a lei determina procedimentos para a legalidade e eficácia das deliberações, devendo o Judiciário ater-se ao controle da legalidade desses atos e não ao mérito da deliberação, conforme será exposto adiante neste trabalho. A interferência judicial, neste aspecto, deve servir para preservar o equilíbrio de interesses e a observância dos preceitos legais 
envolvidos sem, no entanto, substituir o empresário na tomada de decisões atinentes à gestão da sociedade ou substituir o controlador ou os administradores nas questões envolvendo a discricionariedade empresarial de desenvolvimento de suas atividades e no julgamento de conveniência e oportunidade nos negócios dos acionistas e administradores ${ }^{29}$.

Mário Slerca $\mathrm{Jr}^{30}$, analisando essa situação, conclui: "Nessa linha de pensamento, a intervenção judicial limitar-se-á apenas ao controle da legalidade, não podendo tratar o magistrado do mérito propriamente dito da orientação empresarial adotada. Essa pode, até, hipoteticamente, estar, em termos comerciais, errada. No entanto, se proferida dentro dos limites impostos pela lei, o Judiciário não poderá atender às reclamações da minoria acionária e adentrar a verificação do acerto ou erro." 31

O presente trabalho objetiva analisar os princípios gerais que regem a administração e funcionamento das sociedades por ações, e que se encontram refletidos na Constituição Federal de 1988, na Lei 6.404/76 e demais legislação em vigor, e que determinam os limites da intervenção judicial, na análise e controle dos atos praticados pelos acionistas controladores e administradores, para garantia da

\footnotetext{
29 Neste sentido, o Voto do Desembargador Ernani de Paiva, proferido nos autos dos Embargos Infringentes $n^{\circ}$ 107.084-4/9-01, julgados em 04.04.2002, pela 6 Câmara de Direito Privado do Tribunal de Justiça do Estado de São Paulo: "Vale observar que o indigitado dispositivo estatutário e outros pretensamente ilegais constituem assunto da economia interna da sociedade, insuscetível de apreciação pelo Poder Judiciário, consoante anotado no v. voto vencido na apelação (fls. 4.021). Por isso, não deve imiscuir-se o Judiciário na organização interna da entidade-ré, a pretexto de corrigir eventual impropriedade nos textos do seu regulamento. A garantia do livre funcionamento das associações obsta essa intromissão estatal (Constituição Federal, art. 5, XVII e XVIII). O direito de associação é daqueles que podem ser tidos nitidamente como de natureza negativa, é dizer: o Estado o satisfaz, não interferindo na formação das organizações, quer para proibi-las, quer para dificultar o seu funcionamento, quer ainda para determinar a sua dissolução (CELSO RIBEIRO BASTOS e IVES GANDRA MARTINS, Comentários à Constituição do Brasil, $2^{\circ}$ vol., pág. 96). (...) 'A intervenção do Judiciário na vida interna das associações civis não deve exceder os aspectos formais em que se examina a exata aplicação das regras estatutárias' (R.T. 515/223). No mesmo sentido, cf. RJTESP Lex 92/169; R.T. 621/105 e 657/91).”

${ }^{30}$ Controle Judicial dos Atos Empresariais. Atos Relativos à Orientação dos Negócios Sociais e ao Aproveitamento de Oportunidades Comerciais - As Primeiras Decisões da Justiça Brasileira. Revista dos Tribunais, ano 78, volume 640. São Paulo: Revista dos Tribunais, fevereiro, 1989, pág. 58.

${ }^{31}$ E assim prossegue o autor, Controle Judicial..., pág. 58: “12. Definições sobre como melhor perseguir o objetivo social dizem respeito à área privativa do controlador. Nessas escolhas há sempre conhecimentos especializados, sensibilidades, julgamento de risco, que constituem o desafio do empresário. O que se espera dele é o acerto. Todavia, não há, nem pode haver, garantia de que assim suceda. Donde, tal não lhe pode ser judicialmente exigido. Outrossim, é bem de ver que o juiz não tem sequer condições profissionais de se substituir ao controlador, ou à autoridade administrativa, nas escolhas que tratem de julgamentos de oportunidade e conveniências." (Grifo nosso).
} 
manutenção e observância dos interesses próprios da companhia, dos direitos conferidos a seus acionistas e da sua função social, pelo Estatuto Social e pela lei.

Sob esta perspectiva e considerando o resultado das pesquisas realizadas quanto à atuação do Poder Judiciário no Brasil na solução de pendências societárias, também serão analisados os fatores que podem aumentar a eficácia da aplicação da lei e na atuação mais efetiva do Poder Judiciário na interpretação desses princípios gerais para consolidação de sua interpretação, o que irá contribuir para aumentar a segurança das pessoas envolvidas em seu funcionamento, tanto interna, como externamente.

Assim, analisaremos a necessidade de intervenção e os limites da atuação do Judiciário na verificação de ocorrência de abuso de direito de voto, abuso do poder de controle e outros comportamentos de acionistas, minoritários e majoritários, estes últimos observados os deveres e responsabilidades estabelecidos nos artigos $116 \mathrm{e}$ 117 da Lei n $\mathrm{n}^{\circ}$ 6.404/76, sob a perspectiva do princípio do controle majoritário da S.A. como condição necessária para a própria existência dessa sociedade ${ }^{32}$.

Analisaremos também as regras legais para formalização de atos necessários para o regular funcionamento das companhias, especialmente as Assembléias Gerais e Reuniões, bem como as conseqüências de sua inobservância e possibilidade de atuação judiciária para adequação desses atos aos princípios estabelecidos pela Lei 6.404/76.

Para integrar esse quadro e considerando que a jurisprudência brasileira não avançou muito na interpretação dos institutos societários para os quais a Lei das S.A. estabeleceu princípios orientadores, é importante considerar a construção jurisprudencial e doutrinária de outros países, para comparação da evolução e aplicação de institutos utilizados para o controle da administração das sociedades por ações, que

\footnotetext{
${ }^{32}$ Conforme PORZIO, Mario. L'Estinzione della Società per Azioni. Napoli: Cada Editrice Dott. Eugenio Jovene, 1959, pág. 37: "La posizione di possibile contrasto tra il volere del singolo socio e quello della maggioranza espressa nella deliberazione assembleare ha posto il problema, connaturato all'essenza stessa della società e del principio maggioritario, dei limiti entro cui la maggioranza può imporre la sua volontà ai soci dissenzienti."
} 
podem contribuir para o desenvolvimento dessa área do Direito no Brasil, desde que adaptados à realidade social, econômica e jurídica brasileiras.

Dentre os princípios de maior aplicação no exterior, no que se refere à intervenção judiciária e julgamento dos atos praticados por administradores e controladores, a Regra do Julgamento do Negócio ("Business Judgment Rule") ganha destaque por estabelecer regras de análise judicial de atos empresariais, quando esses atos não tragam bons resultados para a companhia, mas foram realizados de boa-fé e os acionistas e administradores tomaram as precauções necessárias para a tomada dessa decisão. Esse instituto, que passou por diversas adaptações decorrentes de alterações econômicas e sociais e da verificação de abusos por parte de acionistas e administradores, visa preservar a liberdade do empresário em tomar decisões e permitir a realização de empreendimentos que, necessariamente, envolverão riscos, mas também considera a necessidade de proteção dos investidores e acionistas minoritários.

Sob essa perspectiva analisaremos no Capítulo IV.5 adiante, os parâmetros de aplicação da Regra do Julgamento do Negócio, que é um princípio central do Direito Empresarial norte-americano, e que garante aos empresários liberdade na condução de seus negócios, considerando que são eles, empresários, e não os tribunais, os detentores da expertise, das informações e técnicas necessárias para condução das atividades da empresa, ao estabelecer limites ao questionamento das decisões tomadas, ainda que prejudiciais, mas de boa-fé, pelos tribunais.

Assim, como ressaltou Mauro Rodrigues Penteado ${ }^{33}$, com fundamento em Ferro-Luzzi, na análise dos casos envolvendo deliberações societárias, devem os tribunais se ater à discussão da "...conveniência e oportunidade da deliberação, mas apenas examinar a sua legitimidade, sob a ótica do bom uso do poder legalmente reconhecido à maioria."

A Regra do Julgamento do Negócio, de início absoluta, passou por um processo de revisão pelos tribunais, especialmente de Delaware, onde estão reconhecidamente os tribunais com maior especialização na área de Direito

\footnotetext{
${ }^{33}$ Aumentos de Capital das Sociedades Anônimas. São Paulo: Saraiva, 1988, pág. 259.
} 
Empresarial, adaptando-a às novas práticas e procedimentos utilizados pelo mercado, a fim de criar limites mais claros e objetivos que determinam a correção das decisões atacadas, coibindo a ocorrência de atos abusivos e contrários aos interesses dos acionistas minoritários e da própria sociedade.

A decisão que é apontada pelos doutrinadores norte-americanos como a mais importante para essa mudança de postura dos tribunais, no sentido de estabelecer limites mais claros e objetivos para atuação dos controladores e administradores foi tomada no julgamento do caso Smith vs Van Gorkon, em janeiro de $1985^{34}$ e provocou reações por parte dos administradores das companhias, em razão do aumento do risco de vierem a ser pessoalmente responsabilizados por decisões empresariais que se revelem prejudiciais à companhia.

A partir desse julgamento, a Corte de Delaware passou a verificar os fatos e procedimentos que levaram à tomada de determinada decisão empresarial e o comportamento dos agentes que tomaram aquela decisão. $\mathrm{O}$ mérito em si da decisão empresarial, ainda que tenha sido prejudicial à sociedade ou aos demais acionistas, não é o objeto principal da análise. O Tribunal se dedica a investigar e determinar se a decisão tomada é legítima, com base em princípios de cautela, boa-fé e informação adequadas que os administradores e acionistas controladores deveriam observar na condução dos negócios sociais.

Desta forma, na análise de um caso concreto em que acionistas minoritários, a própria sociedade ou a comunidade em geral aleguem a ocorrência de prejuízo a seus interesses, em razão de uma decisão empresarial, o juiz, com base nesses princípios, deve verificar se foram tomadas as precauções e observados os deveres legais, a que os controladores e administradores estão obrigados, para, somente então, determinar se foi cometida alguma ilegalidade e se a decisão proferida é passível de anulação.

${ }^{34}$ BLACK, Bernard e KRAAKMAN, Reinier, em Self-Enforcing Model..., pág. 59: "Unlimited director liability for violation of the duty of care can cause outside directors to act too timidly - a threat that became real after the Delaware Supreme Court, in 1985, found a duty of care violation in Smith v. Van Gorkon." 
A aplicação da Regra do Julgamento do Negócio pelos tribunais norte-americanos, é considerada pelos doutrinadores fundamental para garantia da segurança dos fundamentos empresariais e em grande parte contribui para o desenvolvimento do mercado, da economia e para realização de investimentos privados, garantindo aos empresários liberdade para determinar os rumos da empresa, ao mesmo tempo que garante aos investidores externos ao controle das sociedades, proteção contra os abusos da maioria ou da administração.

Sem a existência dos parâmetros contidos nessa Regra, não seria possível proteger os interesses dos acionistas minoritários sem prejudicar o processo de tomada de decisões necessárias para o desenvolvimento das atividades sociais, as quais sempre envolvem um grau de risco e incerteza, sob pena de estes últimos se responsabilizarem pessoalmente por qualquer prejuízo decorrente de uma decisão empresarial, o que, por si só, desestimularia a realização de investimentos empresariais.

Estudos demonstram que em países onde a lei societária oferece maior proteção aos acionistas minoritários, não apenas através de sua legislação, mas também em razão da eficácia dos meios assegurados à legislação, existe um fortalecimento na realização de investimentos diretos em empresas e, consequentemente, no mercado de capitais. Assim, em países onde existe deficiência no sistema que dificultam a eficácia e aplicação das normas ${ }^{35}$, não é apenas a mudança nas leis que possibilitará o desseenvolvimento nessas áreas, é fundamental que a aplicação das leis seja eficiente, que o sistema judiciário consiga, de forma eficaz, criar um ambiente de segurança para o investidor ${ }^{36}$.

35 BLACK, Bernard. Strenghtening Brazil's Securities Markets. Stanford Law School, Out.2000. Working Paper No. 205. Disponível em: 〈http://ssrn.com/abstract_id=247673〉. Acesso em 27.dez.2008. ${ }^{36}$ Luca Enriques, Off the Books, But on the Record: Evidence from Italy on the Relevance of Judges to the Quality of Corporate Law. Bolonha. Disponível em 〈http://ssrn.com/abstractid=300573〉, acesso em 27.nov.2008, pág. 1: "Participants in the debate on law and finance unanimously agree on at least two points. First, law does matter, as a necessary condition or, at the very least, a useful tool for the development of financial markets (...) Second, the relevant factor is not 'law on the books' as much as the combination of law and its enforcement mechanisms. (...) Also La Porta, Lopez-de-Silanes, Shleifer and Vishny (...) are well aware of the need to take enforcement into account in their off-cited statistical analysis. The hypothesis they test is whether in countries with bad law on the books as gauged by their shareholder rights indexes, 'active and well-functioning courts... step in and rescue investors abused by the management', finding that 'legal families with investor-friendlier laws are also the ones with stronger enforcement of the laws. Poor enforcement aggravates, rather than cures, the difficulties faced by investors in the French-civil-law countries", 
Luca Enriques, professor da Universidade de Bolonha, ao comparar os sistemas jurídicos norte-americano e italiano e avaliar as vantagens e desvantagens de cada um, ao lidar com os problemas empresariais, especialmente no caso de abuso do poder de controle, conclui que, independentemente do sistema jurídico e da qualidade da legislação positiva em vigor ("law on the books"), os juízes que atuam nessa área do direito devem ter uma preocupação maior no resultado prático de suas decisões, as quais influenciarão o comportamento daqueles que atuam na área empresarial e serão fundamentais para determinar a qualidade do ambiente empresarial e, de forma reflexa, contribuirão para o desenvolvimento da economia e do mercado daquele país.

Para que o Judiciário assuma essa atitude mais ativa, este autor ${ }^{37}$ defende que os juízes, além do pressuposto de agirem com honestidade e possuírem os conhecimentos técnicos necessários para atuar nessa área, deverão (a) não apresentar atitudes deferenciais com relação às partes envolvidas; (b) ter a sensibilidade para descobrir qual é realmente o problema existente entre as partes litigantes e as causas reais da disputa que levaram ao ajuizamento da ação; (c) se afastar da cultura legal formalista; (d) se preocupar com o impacto de suas decisões no futuro comportamento das pessoas envolvidas no ambiente empresarial, em geral.

Acima de tudo, ainda que a legislação de um país seja avançada e em conformidade com as necessidades empresariais e da economia, a má aplicação da lei, a desconfiança quanto à isenção dos juízes ou a ineficácia das decisões judiciais, especialmente em razão da demora na solução de um processo envolvendo decisões empresariais $^{38}$, aumenta o clima de insegurança e incerteza entre os investidores,

37 Off the Books..., pág. 2: "I argue that, in order to provide a good corporate law landscape, a country must have honest and sophisticated judges who: (1) show no deferential attitude towards insiders when conflict-of-interest situations are involved; (2) are endowed with the 'nose' to sense what really is at stake among the litigants and the real causes of the dispute that has led the plaintiff to bring suit; (3) do not partake of a formalistic legal culture; (4) are concerned with the impact of their decisions on the future behavior of corporate actors in general."

${ }^{38}$ A rapidez exigida para realização de operações empresariais, exige uma atuação mais eficaz por parte do judiciário. Como apontaram Bernard Black e Reinier Kraakman, em A Self-Enforcing Model..., pág. 02, em países que possuem economia e o mercado de capitais mais desenvolvidos e juízes especializados nessa matéria, é possível que uma decisão bem fundamentada e em consonância com os objetivos e princípios empresariais seja tomada, de um dia para o outro, para garantir a realização de uma operação que está sendo questionada. Em países de economia emergente, dentre elas os autores incluíram em sua pesquisa o Brasil, a rapidez e confiança nas decisões judiciais está, simplesmente, "fora de questão", 
reduzindo o grau de confiança, especialmente de investidores estrangeiros e, consequentemente, reduzindo os investimentos diretos no país ${ }^{39}$.

Muitas críticas são feitas quanto à eficácia do sistema jurídico de tradição romano-germânica, como o Brasileiro, e sua capacidade de acompanhar a evolução da economia e encontrar soluções para as controvérsias surgidas de situações inéditas e muitas vezes ainda não regradas expressamente pelo sistema jurídico, havendo até aqueles que defendem que, nessa área, o direito da common law teria mais flexibilidade para atender prontamente a essas situações, na medida em que os juízes possuiriam maior liberdade para decidir e não dependeriam de alterações legislativas as quais, muitas vezes, resultam de articulações e vontade políticas.

No entanto, entendemos, assim como concluiu Luca Enriques em sua comparação entre os sistemas jurídicos norte-americanos e italiano e a atuação dos tribunais de Delaware e Milão, que a resposta para essa questão não está diretamente relacionada com o sistema jurídico adotado por um país mas sim com o tratamento às controvérsias surgidas dado por seus tribunais, e o preparo dos juízes ao compreender e interpretar o universo empresarial e promover o equilíbrio dos interesses econômicos e sociais envolvendo as S.A., através da compreensão dos princípios que regem esses interesses, de forma a alcançar decisões eficazes para os problemas enfrentados pelos empresários na condução de seus negócios.

Pesquisas recentes conduzidas por Pierre-Henri Conac, Luca Enriques e Martn Gelter ${ }^{40}$ demonstram que países como a França, Itália e Alemanha, que também seguem a tradição romano-germânica, possuem legislação avançada que contempla e regulamenta os principais problemas surgidos na administração das sociedades por ações, oferecendo soluções, muitas vezes até mais eficazes do que as

contribuindo para o pouco desenvolvimento do mercado em razão da insegurança trazida àqueles que atuam na área, quanto à ineficácia de decisões judiciais.

${ }^{39}$ Off the Books..., pág. 3: "At the most basic level, there is widespread agreement that a certain degree of judicial honesty and effectiveness (in terms of speed and practical enforceability of court decisions) are necessary elements of a sound corporate law system (La Porta et at. 1998: 1140, Black 2001a: 790-91 and 807). Their absence is a real problem today mainly in developing countries."

${ }^{40}$ Constraining Dominant Shareholders' Self Dealing: The Legal Framework in France, Germany and Italy. Cambridge: Harvard Law School. John M. Olin Center for Law, Economics and Business. Fellows' Discussion Paper Series No. 18, Julho de 2008. <Disponível em http://www.law.harvard.edu/programs/olin_center>, acesso em 18.nov.2008. 
determinadas pela Corte de Delaware. Assim, na opinião desses autores, o problema, não estaria no conteúdo da legislação, mas em sua interpretação e aplicação eficaz pelos tribunais.

A Lei 6.404/76, editada há mais de 30 anos, oferece os mecanismos necessários para enfrentar as controvérsias surgidas nos dias de hoje. A compreensão, pelos tribunais Brasileiros dos princípios por ela estabelecidos, e sua aplicação eficaz, dentro do contexto que envolve o Direito Empresarial no Brasil, é de fundamental importância para que oferecer maior segurança aos empresários e investidores e para determinar os parâmetros de comportamento ético deles exigido, possibilitando, assim, o desenvolvimento não apenas do mercado de capitais como da própria economia do país.

Essa interpretação integrada garante efetividade à lei e aumenta a segurança do ambiente empresarial, definindo os padrões de comportamento e limites ao poder dos controladores e administradores, o que reforça a proteção dos minoritários e terceiros, diminuindo a percepção de que estes não possuem meios de defesa contra os desmandos e abusos dos controladores, e que seus investimentos e o patrimônio da sociedade ficarão sujeitos à vontade e interesses pessoais dos controladores e administradores.

Como já anotava Waldemar Ferreira ${ }^{41}$, ainda sob a égide do Decreto $\mathrm{n}^{\mathrm{o}}$ 434, de 04.07.1891: "Murmura-se no mundo dos negócios, afirma-se

${ }^{41}$ O Direito Insurrecional do Acionista. São Paulo: Revista dos Tribunais, 1939, págs. 5 e 6. Nesse livro o autor apresenta apelação interposta contra sentença proferida nos autos de ação proposta por acionistas minoritários da Companhia Agrícola Pedro João, contra esta última e o Coronel Vicente Soares de Barros, tendo por objetivo a decretação de nulidade da venda, pela Companhia, de imóveis de sua propriedade, ao Coronel. O Autor assim descreve os atos que fundamentaram a ação, pág. 17: "Caso foi que, convocada assembléia extraordinária dos acionistas da Companhia Agrícola Pedro João e realizada, em 1 de maio de 1930, com o objetivo de tratar de 'negócios do interesse social', mudou-se-lhe a finalidade colocando-se na ordem do dia matéria estranha ao interesse social, mas do só e único interesse do seu diretor presidente e maior acionista, Pedro Izar. Nela, com efeito, se conheceu de proposta 'sobre a alienação dos prédios ns. 32, 34, 36 e 38 da rua Santo André, em São Paulo, com outorga da escritura definitiva ou de compromisso'. Era ela, com efeito indispensável ao interesse social? Destinava-se, acaso a ministrar recursos à sociedade, para que, por exemplo, cumprisse ela obrigações presentes e inadiáveis? Impunha-se a necessidade de obter numerário para suprir sua falta e, dessarte, realizar negócios que a desafogassem? Não. O negócio, submetido ao conhecimento da assembléia geral extraordinária, não era, de modo algum, do interesse social. Dizia, exclusivamente, do interesse particular do seu diretorpresidente e maior acionista, Pedro Izar. Nada tinha a sociedade que ver com o negócio, para que a asembléia geral de seus acionistas foi convocada extraordinariamente. Abertos os trabalhos daquela asssembléia, fez-lhe saber seu presidente que o diretor-presidente efetivo da sociedade, Pedro Izar, lhe 
também no cosmos jurídico, com certa persistência, nada poderem os acionistas de sociedades anônimas ou comanditárias por ações reclamar contra o deliberado pelas assembléias gerais daquelas ou destas. Prevalece em tudo e por tudo a vontade da maioria. (...) A predominância da vontade majoritária dos acionistas, em regra, forma a vontade social, inteiramente capaz de adquirir direitos e contrair obrigações, responsabilizando, dessarte, todo o patrimônio social. Quem validamente se obriga, por todo o seu patrimônio responde. (...) Não é, pois, absoluta a maioria dos acionistas. O seu poder deliberatório, em alguns casos, é substituído pelo da minoria. Em casos outros, ao acionista pertence invocar a ação judiciária para a decretação da nulidade ou para a anulação dos atos e contratos celebrados em virtude de deliberação da maioria. Está ela, portanto, submetida ao controle judiciário."

Finalmente, um aspecto de extrema importância que deve ser observado na análise das situações trazidas a julgamento pelo Judiciário e que será analisado ao longo deste trabalho, envolve as características da companhia envolvida na demanda. Uma companhia de capital aberto, com capital diluído no mercado, exige determinados procedimentos, por parte dos administradores, para atender às necessidades de transparência tomada e controle das decisões, e a grande maioria de

havia prestado 'inúmeros serviços extraordinários, e valiosos, sem remuneração alguma'. Era o intróito da proposição. Consistia esta em afirmar que tendo aquele se constituído, pessoalmente, devedor a Vicente Soares de Barros do preço de fazenda, que lhe havia comprado, devia a sociedade assumir 'a responsabilidade de parte do débito no valor total de 1.050:000\$000'. Lembrou-se, então, que a sociedade desse ao credor particular de seu diretor-presidente os prédios da rua Santo André em hipoteca ou em pagamento ou se comprometesse a vende-los por aquele preço. A proposta em que a sugestão se consubstanciou, foi aprovada. Tudo isso consta, pormenorizadamente, da ata da assembléia referida, que se encontra na fotografia de fls. 156 e 157. Nela não se ocultou, porém, que o negócio não interessava, diretamente, à sociedade e sim ao seu diretor-presidente. 'Tratando-se', nela se lê, 'tratando-se de CONTRATOS QUE INTERESSAM O PRESIDENTE EFETIVO DIRETAMENTE...', proposto ainda foi que 'as respectivas escrituras fossem assinadas pelo acionista Alfredo Salim Izar, como representante da companhia, com poderes expressos para todos aqueles negócios'. Ficou, pois, indisfarçavelmente consignado na própria ata da assembléia geral, em termos inequívocos, não ser o negócio, sobre que ela deliberou, de modo nenhum, direto ou indireto, do interesse da sociedade, tratando-se nela de "contratos que interessam o presidente efetivo diretamente". (Grifos no original). Assim, não obstante o fato de constar da própria ata da assembléia na qual se deliberou a alienação dos imóveis da companhia para pagamento de dívida particular de seu principal acionista e diretor-presidente, o histórico dos fatos que envolvem o conflito de interesses entre este e a companhia e a declaração de que a alienação desses imóveis era de interesse exclusivo do acionista majoritário, não havendo referência ou justificativa para prática dos atos em benefício da sociedade, a sentença de primeiro grau julgou os autores carecedores da ação em relação ao Coronel (adquirente dos imóveis da Companhia) e a ação improcedente quanto à Companhia. O Autor defende a nulidade das deliberações tomadas na assembléia geral da companhia, sob o fundamento de que o interesse da companhia não norteou a aprovação das deliberações tomadas e que esta não foi beneficiada pela venda dos imóveis, pelo contrário. Da mesma forma, considerando que o Coronel tinha conhecimento das manobras societárias realizadas para permitir a venda dos imóveis da companhia, para saldar a dívida do seu devedor, não se poderia alegar sua boa-fé e, portanto, a preservação dos atos praticados em cumprimento às deliberações tomadas em assembléia. 
seus acionistas atua como investidores capitalistas que investem sob a expectativa de retorno de seu capital, na forma de dividendos ou aumento do valor de suas ações. Nas companhias fechadas, muitas vezes familiares, que constituem a grande maioria das S.A. no Brasil, com poucos acionistas e entraves para circulação de ações, os acionistas possuem outros interesses além do retorno do seu capital e os procedimentos decisórios e de controle são de menor complexidade. O Judiciário deve considerar essas características, para interpretação dos princípios e interesses que regem cada um desses tipos societários, procurando compreender a situação envolvendo a companhia e os interesses nela envolvidos, para somente então determinar as medidas de proteção aos direitos e interesses daqueles que buscam a proteção jurisdicional, sob pena de inadequação e ineficácia da medida determinada ${ }^{42}$.

\footnotetext{
${ }^{42}$ Nos Estados Unidos, a diferenciação entre sociedades por ações de capital aberto e de capital fechado, e o número de sócios que compõem o quadro social, determinam procedimentos de proteção dos acionsitas, específicos para cada um desses tipos, como ressaltam Bernard BLACK e Reinier KRAAKMAN, A SelfEnforcing Model..., pág. 07: "The procedural protections that are appropriate for a company with 10,000 shareholders would be ludicrous and crippling for a tiny company with five shareholders who all work in the business.
} 


\title{
II - A LEGISLAÇÃO SOCIETÁRIA COMO LEGISLAÇÃo "INCOMPLETA"
}

\begin{abstract}
Nos países que adotam o sistema jurídico de tradição romanogermânica na ocorrência de um conflito de interesses juridicamente relevante, as leis existentes necessariamente deverão ser interpretadas pelo órgão destinatário competente, para que, identificada a norma aplicável, gere os efeitos pretendidos no caso concreto. Conforme lição de Kelsen, a identificação da norma positiva aplicável ao caso concreto e sua interpretação pelo órgão competente finaliza o processo de criação jurídica e gera a norma jurídica individual ${ }^{43}$.
\end{abstract}

$\mathrm{Na}$ interpretação de uma lei deve-se considerar não apenas o momento econômico e social em que estava inserido aquele país e dentro do qual a lei foi promulgada, como também as modificações ocorridas nesse cenário, quando de sua aplicação concreta.

Para que as leis possuam essa capacidade de adaptação às mudanças sociais e econômicas que ocorrerão durante todo o período em que permanecerem em vigor, muitas das disposições nelas contidas deverão conter termos abertos que não especifiquem exaustivamente as situações por elas disciplinadas.

Essa "incompletude" das normas, além de ser uma característica necessária, está longe de ser um problema, na medida em que é justamente ao analisar essas normas abertas e procurar encontrar-lhes o significado, interpretando-as, que os operadores de direito poderão adaptá-las aos casos concretos e aplicá-las de forma mais eficaz.

${ }^{43}$ Teoria Pura do Direito. $2^{\text {a }}$ edição. São Paulo: Livraria Martins Fontes Editora, 1987, pág. 272: “Os tribunais criam o Direito, a saber - em regra - Direito Individual; mas, dentro de uma ordem jurídica que institui um órgão legislativo ou reconhece o costume como fato produtor de Direito, fazem-no aplicando o Direito geral já de antemão criado pela lei ou pelo costume. A decisão judicial é a continuação, não o começo, do processo de criação jurídica." 
Os sistemas jurídicos, através de normas específicas aplicáveis a determinado comportamento ou através dos princípios gerais que o regem, contém os elementos necessários para que os tribunais, como destinatários e intérpretes legítimos da norma, possam enquadrar a situação em litígio e determinar o interesse jurídico que deve ser protegido, conforme propõe Kelsen ${ }^{44}$ : "A norma jurídica geral é sempre uma simples moldura dentro da qual há de ser produzida a norma jurídica individual. Mas esta moldura pode ser mais larga ou mais estreita. Ela é o mais larga possível quando a norma jurídica geral positiva apenas contém a atribuição de poder ou competência para a produção da norma jurídica individual, sem preestabelecer seu conteúdo."

E essa moldura, representada pela norma jurídica positiva, deve ser preenchida através da interpretação dos tribunais, que determinarão as hipóteses que estão nela contidas, finalizando o processo de criação da norma ${ }^{45}$.

O poder conferido aos tribunais para interpretar a norma e identificar seu conteúdo através da determinação das hipóteses a ela aplicáveis, dentre aquelas que são levadas a seu conhecimento, possibilita a adaptação das normas às novas situações decorrentes das constantes mudanças econômicas e sociais que alteram os costumes e práticas.

Para isso, a legislação estabelece conceitos gerais e abertos que determinam princípios a serem analisados e identificados de acordo com as demais regras que compõem o sistema jurídico e que terão seu significado concreto determinado de acordo com a situação real apresentada à análise.

\footnotetext{
${ }^{44}$ Teoria Pura..., pág. 262.

${ }^{45}$ Teoria Pura...., pág. 366: "Se por 'interpretação' se entende a fixação por via cognoscitiva do sentido do objeto a interpretar, o resultado de uma interpretação jurídica somente pode ser a fixação da moldura que representa o Direito a interpretar e, consequentemente, o conhecimento das várias possibilidades que dentro desta moldura existem."
} 
Para essa análise, ressaltamos a posição de Eros $\mathrm{Grau}^{46}$, que defende que a referência a "conceitos jurídicos indeterminados", traz em si um erro grave: "A exposição assim desenvolvida voltava-se ao desnudamento da falácia dos conceitos jurídicos indeterminados. É que a indeterminação a que nos referimos, na hipótese, não é dos conceitos jurídicos (idéias universais), mas de suas expressões (termos); logo, mais adequado será referirmo-nos a termos indeterminados de conceitos, e não a conceitos (jurídicos ou não indeterminados).(...) Se é indeterminado o conceito, não é conceito. O mínimo que se exige de uma suma de idéias, abstrata, para que seja um conceito, é que seja determinada. (...) Se o conceito não for, em si, uma suma determinada de idéias, não chega a ser conceito. Assim, a reiteradamente referida indeterminação dos conceitos não é deles, mas sim dos termos que os expressam." (Grifos no original)

Desta forma, ao nos referimos daqui em diante a normas abertas, que exigem a interpretação do órgão legítimo e competente para determinação de seu conteúdo e sua aplicação ao caso concreto, estamos, na verdade, afirmando que essas normas contem termos abertos, abstratos, que especificam um conceito jurídico e possibilitam a interpretação e complementação da norma de forma mais ampla e flexível. O conceito está determinado na norma (boa-fé, má-fé, conflito de interesses, abuso de poder etc.), mas os termos contidos na norma é que foram intencionalmente incluídos pelo legislador para conferir à lei a abertura e maleabilidade necessária para que os tribunais interpretem tais termos e determinem seu(s) significado(s) através de sua aplicação concreta.

Essa maleabilidade na interpretação das normas, ao mesmo tempo em que é fundamental em áreas como o Direito Societário, que é diretamente

${ }^{46}$ O Direito Posto e o Direito Pressuposto. $5^{\text {a }}$ edição. São Paulo: Malheiros Editores, 2003, pág. 196. Para essa conclusão, Eros Grau sistematiza da seguinte forma sua opinião: “(i) a cada conceito corresponde um termo; este - o termo, é o signo lingüístico do conceito; assim, o conceito, expressado no seu termo, é coisa (signo) que representa outra coisa (seu objeto); o conceito, na concepção aristotélica, está referido, pela mediação do termo (signo do conceito), a um objeto; (ii) os conceitos jurídicos não são referidos a objetos, mas sim a significações; não são conceitos essencialistas; (iii) o conceito essencialista ou não- é produto da reflexão, expressando uma suma de idéias; (iv) o conceito essencialista, expressado, é o signo de uma coisa; seu objeto é a coisa; está no lugar da coisa; é o primeiro signo do objeto; (v) o conceito jurídico, expressado, é o segundo signo de um primeiro signo: a significação da coisa (coisa, estado ou situação); está no lugar não da coisa (coisa, estado ou situação) mas da significação atribuível - ou não atribuível - à coisa (coisa, estado ou situação); (vi) assim, os conceitos jurídicos são signos, ou seja, signos de significações atribuíveis - ou não atribuíveis - a coisas, estados ou situações." (Grifos no original) 
influenciado pelas mudanças sociais, econômicas e tecnológicas ${ }^{47}$, confere maior liberdade e, ao mesmo tempo, responsabilidade, aos tribunais, encarregados de analisar e atribuir significado ao conceito abstrato da norma ${ }^{48}$.

Cinzia $\mathrm{Gamba}^{49}$ ao se referir às normas que contém esses termos abertos, utiliza a expressão "norma elástica",50, e conclui que a compreensão e aplicação, pelo juiz, ao interpretar e aplicar uma norma que contém uma fattispecie legal incompleta, que remeta a cláusulas gerais ou a standards, exige dele uma verdadeira e própria atividade de integração do texto normativo ${ }^{51}$. E conclui que, na aplicação dessas normas elásticas, a posição do juiz é diversa daquela normalmente exercida para tutela de direitos expressamente regulados por normas jurídicas completas, na medida em que será dele exigido não apenas determinar a existência e o conteúdo de um título constitutivo do direito, mas sim avaliar um conflito de interesses em seu conjunto, servindo como mediador dos interesses envolvidos. Desta forma, a decisão da controvérsia exigirá a análise, em perspectiva, dos interesses em jogo que não estão ainda definitivamente regulados no plano do direito positivo e que serão compostos mediante intervenção regulativa ${ }^{52}$.

\footnotetext{
${ }^{47}$ Neste sentido, GRAU, Eros, Direito Posto..., pág. 202: "Deveras, a questão da indeterminação dos conceitos se resolve na historicidade das noções - lá onde a doutrina brasileira erroneamente pensa que há conceito indeterminado, há, na verdade, noção. E a noção jurídica deve ser definida como idéia que se desenvolve a si mesma por contradições e superações sucessivas e que é, pois, homogênea ao desenvolvimento das coisas (Sartre)." (Grifos no original).

${ }^{48}$ PRADO, Viviane Muller, analisando a teoria da incompletude da legislação, em Reflexões sobre Enforcement de Normas Societárias, em Poder Judiciário e Desenvolvimento do Mercado de Valores Mobiliários Brasileiro. São Paulo: Saraiva, 2008, assim conclui na pág. 119: "O que pretendemos trazer dessa teoria é a seguinte idéia: a partir do momento que se têm regras abertas, tais como, conceitos indeterminados e cláusulas gerais, deve-se ter preocupação diversa com a efetividade e preenchimento do significado da norma quando da sua aplicação ao caso concreto."

${ }^{49}$ Diritto Societario..., pág. 104.

${ }^{50}$ Termo também utilizado por WALD, Arnoldo, Direito Civil, Introdução e Parte Geral, $11^{\mathrm{a}}$ edição. São Paulo: Saraiva, 2009, pág. 42: "Podemos ainda distinguir as normas rígidas e as normas elásticas. A norma é rígida quando o preceito nela contido não deixa nenhum arbítrio ao órgão encarregado de sua aplicação. São elásticas as normas cujo sentido depende de apreciação individual e subjetiva do juiz." e REALE, Miguel, Fontes e Modelos do Direito: para um Novo Paradigma Hermenêutico. São Paulo: Saraiva, 2002, pág. 32: "Podemos dizer com Pontes de Miranda - cuja obra principal se liga fundamentalmente à dos pandectistas, só que numa perspectiva neopositivas - que a norma jurídica é, via de regra, dotada de certa elasticidade, de tal modo que o intérprete pode adaptá-la ou adequá-la a imprevistas circunstâncias, graças a um processo hermenêutico histórico-evolutivo e onmi-compreensivo, ou, por melhor dizer, inserido concretamente na dialeticidade da experiência social."

${ }^{51}$ Diritto Societario..., pág. 105: "Nelle riscostruzioni più evolute, si è tentato di delineare i confini dogmatici di una tutela 'determinativa' con proprie peculiarità sistematiche, da configurare nelle ipotesi in cui (come accade in relazione alle norme che contengono clausole generali o il rinvio a standards) le fattispecie legali non sono complete in tutti i loro elementi ma presentano una componente elástica, che richiede all'interprete una vera e propria atività di integrazione del texto normativo."

${ }^{52}$ Diritto Societario..., pág. 106.
} 
Para solução do conflito de interesses sujeito àquela norma, o juiz deverá realizar um trabalho de integração no qual se sobressaem dois aspectos principais: (a) a individualização dos fatos relevantes que compõem o cenário no qual se desenvolveu o conflito; e (b) a avaliação dos interesses envolvidos ${ }^{53}$.

O primeiro aspecto, diz respeito à individualização dos fatos relevantes para a solução do conflito. Com efeito, a hipótese jurídica regulada por esse tipo de norma é composta de uma série de fatos não especificamente definidos ou mesmo por situações de fato indeterminadas. Assim, a lei não individualiza com precisão os fatos constitutivos mas se limita a definir genericamente uma situação, delegando ao juiz a tarefa de individualizar os fatos constitutivos relevantes contidos naquela norma. Para isso, é fundamental que o juiz tenha acesso à situação real que originou aquele conflito e não apenas aos fatos imediatos que fundamentam o pedido do autor. A necessidade de análise dos fatos que cercam o conflito abre espaço para a evolução da interpretação da norma e permite a introdução, no mundo jurídico, de fatos que permitem uma nova interpretação da norma, o que leva à evolução do próprio Direito $^{54}$.

O segundo aspecto relacionado à solução da controvérsia enquadrada em uma norma elástica, revela que a análise individual do conflito apresentado pelo juiz não indica isoladamente qual o tipo de interesse relevante que a norma procura proteger. A norma reenvia o juiz a parâmetros valutativos que devem ser a ela integrados para interpretação de seu significado no caso concreto. Assim, é exigido do juiz realizar "delicados juízos de valores" ampliando sua margem de

${ }^{53}$ Diritto Societario..., págs. 108 a 110.

${ }^{54}$ Diritto Societario..., págs. 108 e 109: "...si trascura completamente che il giudice deve individuare quali siano i fatti rilevanti, determinati in modo vago dalla norma elastica. (...) In realtà, lo schema strutturale delle norme elastiche è riconducibile alla struttura condizionale che caratterizza tutte le norme: è composto cioè da una protasi, ossia da una descrizione di fatti o di una classe di fatti, i quali costituiscono la condizione per il verificarsi degli effetti giuridici e quindi sono costitutivi del diritto. La particolarità consiste nel fatto che, in questi casi, la protasi è particolarmente vaga ed indeterminata, in quanto rinvia a classi di fatti non specificamente definite ovvero a situazioni di fatto indeterminate. (...) Il giudice è pertanto chiamato a farsi parte attiva nel processo di concretizzazione delle fattispecie, avendo come diretto riferimento le circostanze reali della controversia. (..) Il riferimento alla realtà porta in primo piano i fatti che fondano la posizione soggettiva. (...) In questo senso, l'ingresso della realtà nel suo divenire e nelle sue nuove forme significa che attraverso le norme elastiche il diritto recepisce anche la complessità della realtà: atraverso l'apertura delle fattispecie si crea il passaggio attraverso il quale possono penetrare nel diritto le nuove situazioni che la realtà nel suo divenire propone." 
discricionariedade. Desta forma, não obstante deva ser considerado pelo juiz a necessidade de proteção de interesses mais fracos em relação aos interesses da companhia, isso não significa que os primeiros devam prevalecer sempre em relação aos segundos. O juiz, especialmente nesses casos, deve considerar a situação fática concreta e sopesar os interesses em jogo a fim de se determinar aquele que, naquela situação controversa, é protegido pela norma e deverá prevalecer sobre os demais ${ }^{55}$.

Dalmo de Abreu Dallari ${ }^{56}$, examinando a evolução da jurisprudência da Suprema Corte dos Estados Unidos, ressalta que no século XIX "...houve o reconhecimento de que não é possível julgar com justiça aplicando a lei em seu estrito sentido literal, ignorando a mudança do sentido das palavras, das circunstâncias sociais, dos costumes e da própria escala de valores dos povos, influenciados por novas condições de vida e de convivências. Assim é que, partindo da interpretação exclusivamente literal das leis, no momento de sua aprovação, os juízes da Suprema Corte americana reconheceram a necessidade de levar em conta a atualização do sentido das palavras."

Os autores do Código Civil Brasileiro atualmente em vigor (Lei 10.406) também foram sensíveis à necessidade de adoção de um sistema aberto, com normas com conteúdo adaptável às mudanças sociais e econômicas que influenciam a aplicação concreta dos conceitos nelas contidos, ao contrário do sistema adotado no Código Civil de 1916, considerado mais fechado e estático e que formava "um corpo fechado de normas", em que a solução para o caso concreto deveria ser indicada pela lei, assim como suas conseqüências (conceitos determinados)" ${ }^{, 57}$. Por esse motivo, o

\footnotetext{
${ }^{55}$ Diritto Societario..., págs. 109 e 110: "Sotto un ulteriore profilo, la figura del conflitto di interessi non è idonea, di per sé, a dare indicazioni su quale tipo di interessi debba essere perseguito dal soggetto che detene il potere, ovvero quale criterio debba utilizzare il giudice per dirimere il conflitto di interessi da cui è sorta la controversia. In questo senso, il riferimento al conflitto di interessi si risolve in una formula 'vuota' - in quanto se non vi fosse conflitto tra interessi contrastanti non vi sarebbe controvérsia - ed autoreferenziale, poiché è incapace di fornire al giudice i parametri di scelta tra i vari interessi in contrasto. (...) Il problema, in realtà, risiede nel fatto che la formula del conflitto di interessi non è capace di mettere in evidenza il secondo livello di apertura delle norme 'elastiche', consistente nel fatto che lo standard in essa contenuto rinvia a parametri valutativi da ricavare da sistemi di valori o complessi di regole esterni al diritto. (...) Come si è affermato in dottrina, al giudice vengono demandati delicati giudizi di valore che fanno si che egli svolga un compito particolarmente delicato. Emerge la figura del giudice policy-maker, che formula la decisione con ampio margine di discrezionalità... (...) La riscostruzione veritiera dei fatti costituisce una condizione imprescindibile affinché il giudice possa compiere una corretta individuazione dei parametri di valutazione in base ai quali integrare lo standard."

${ }^{56}$ O Poder dos Juízes. $3^{\text {a }}$ edição. São Paulo: Saraiva, 2007, pág. 100.

${ }^{57}$ WALD, Arnoldo, Direito Civil..., pág. 89.
} 
sistema atual do Código Civil difere do anterior, justamente por utilizar fórmulas e conceitos abertos, o que lhe confere mobilidade e capacidade de rápida adaptação às mudanças sociais, evitando alterações legislativas constantes e aumentando, por outro lado, a responsabilidade do Judiciário em adaptar essas normas abertas ao caso concreto, as quais devem ser aplicadas em consonância com os princípios gerais que regem o sistem do Código Civil ${ }^{58}$.

O sistema da Lei das S.A., assim entendido como o conjunto formado pelas normas jurídicas nela previstas, integrado aos institutos e princípios que regem a matéria, constitui um sistema autônomo dentro do sistema que abrange todos os campos do Direito Privado e evidencia os princípios específicos que regem as sociedades por ações, construídos com base na experiência prática dos empresários e dos tribunais, os princípios gerais de conduta do Direito Privado e, principalmente os princípios constitucionais que, conforme referido anteriormente, estabelecem os limites para exercício da livre iniciativa.

Como ressaltou Miguel Reale ${ }^{59}$, os princípios que orientam um determinado sistema legal, podem ser entendidos como os "enunciados lógicos admitidos como condição ou base de validade das demais asserções que compõem um dado campo do saber", que constituem “"verdades fundantes' de um sistema de conhecimento, como tais admitidas, por serem evidentes ou por terem sido comprovadas, mas também por motivos de ordem prática de caráter operacional, isto é, como pressupostos exigidos pelas necessidades de pesquisa e da praxis.”.

\footnotetext{
${ }^{58}$ WALD, Arnoldo, Direito Civil..., pág. 89: “O Código Civil de 2002, diferentemente do Código de 1916, adotou um sistema aberto (dinâmico). Na legislação anterior, o sistema era fechado (estático). Sistema, segundo Savigny, é a 'conexão interna que liga todos os institutos jurídicos e as normas jurídicas numa grande unidade'. Assim, o Código anterior seguia o sistema estático, formando um corpo fechado de normas, isto é, a solução para o caso concreto deveria ser indicada pela lei, bem como suas consequiências (conceitos determinados). O atual Código Civil, por possuir as denominadas cláusulas gerais e conceitos indeterminados, adotou um sistema aberto, que lhe dá mobilidade, o que possibilita uma solução para os conflitos de interesses, mesmo quando não haja uma norma específica. Evita-se, assim, a criação constante de leis diante das rápidas transformações sociais, econômicas e tecnológicas. As cláusulas gerais permitem ao magistrado criar direitos e obrigações, como se verifica nos arts. 421 (função social do contrato) e 422 (boa-fé objetiva), dentre outros. O sistema atual é dinâmico e, portanto, dotado de mobilidade, permitindo ao juiz criar uma solução para o caso concreto."

${ }^{59}$ Lições Preliminares de Direito. $27^{\mathrm{a}}$ Edição, $7^{\mathrm{a}}$ Tiragem. São Paulo: Saraiva, 2007, págs. 303, 316 e 317.
} 
Determinados princípios, por sua relevância e generalidade, estruturam o sistema jurídico nacional como um todo e orientam a elaboração e interpretação das normas de cada sistema específico por ele abrangido, estabelecendo preceitos fundamentais, que determinam princípios que protegem "a intangibilidade dos valores da pessoa humana (...)à boa fé como pressuposto de conduta jurídica; à proibição de locupletamentos ilícitos; ao equilíbrio dos contratos, com a condenação de todas as formas de onerosidade excessiva para um dos contratantes; a preservação da autonomia da instituição familiar; à função social da propriedade, à economia das formas e dos atos de procedimento; a subordinação da atividade administrativa aos ditames legais; à proteção da rápida circulação das riquezas e à crescente formalização de crédito; à exigência de justa causa nos negócios jurídicos; aos pressupostos da responsabilidade civil ou penal etc." ${ }^{60}$

Cada ramo de um sistema jurídico, por outro lado, possui princípios e diretrizes próprios, correspondentes às características da área por ele abrangida. Desta forma, os princípios específicos que regem o Direito do Trabalho, o Direito Penal, o Direito Civil, o Direito de Família e o Direito Empresarial, dentre outras áreas, foram definidos e desenvolvidos ao longo do tempo, de acordo com as modificações ocorridas nessas áreas da sociedade e, consequentemente, das situações por eles reguladas, mas que devem obedecer aos princípios teóricos básicos que regem o sistema jurídico nacional e que expressam os valores econômicos e sociais da sociedade em um determinado momento histórico.

Dentre os princípios definidores da ordem econômica e jurídica brasileira estão os previstos no inciso IV do artigo $1^{\circ}$, no inciso XVII do artigo $5^{\circ}$ e no artigo 170 da Constituição Federal ${ }^{61}$, que refletem as diretrizes gerais do sistema

${ }^{60}$ REALE, Miguel. Lições Preliminares..., pág. 305 e 306.

61 “Art. $1^{\mathbf{0}}$ A República Federativa do Brasil, formada pela união indissolúvel dos Estados e Municípios e do Distrito Federal, constitui-se em Estado Democrático de Direito e tem como fundamentos: (...) IV - os valores sociais do trabalho e da livre iniciativa;" "Art. 5'. (...) XVII - é plena a liberdade de associação para fins lícitos, vedada a de caráter paramilitar;" "Art. 170. A ordem econômica, fundada na valorização do trabalho humano e na livre iniciativa, tem por fim assegurar a todos existência digna, conforme os ditames da justiça social, observados os seguintes princípios: I - soberania nacional; II - propriedade privada; III - função social da propriedade; IV - livre concorrência; V - defesa do consumidor; VI defesa do meio ambiente, inclusive mediante tratamento diferenciado conforme o impacto ambiental dos produtos e serviços e de seus processos de elaboração e prestação; VII - redução das desigualdades regionais e sociais; VIII - busca do pleno emprego; IX - tratamento favorecido para as empresas de pequeno porte constituídas sob as leis brasileiras e que tenham sua sede e administração no País. 
ecômico brasileiro, de orientação capitalista liberal, dentre elas: (a) a proteção à propriedade privada; (b) a liberdade de empresa e de escolha; (c) o interesse próprio como móvel dominante; (d) a competição; (e) a confiança no sistema de preços; e (f) a função limitada do governo nas atividades empresariais ${ }^{62}$.

Em contrapartida à liberdade conferida à iniciativa privada e, sendo o Estado responsável pela organização da economia e o desenvolvimento nacional, voltados para a construção de uma sociedade livre, justa e solidária e erradicação da pobreza e da marginalização e redução das desigualdades sociais e regionais ${ }^{63}$, cabe ao Estado “...orientar e controlar a atividade dos particulares, máxime quando a estes se delega, num aspecto principal ou subsidiário, total ou parcial, executar uma parte desse mister. Para tanto, serve-se o Estado do planejamento (indicativo ou flexível), da política tributária e do poder de política, instrumentos oficiais que servem de contrapartida à livre iniciativa dos partiulares no setor econômico.”, como analisa Paulo Salvador Frontini ${ }^{64}$.

O Direito Comercial, tem ainda como uma de suas características marcantes, desde o início de sua criação como um conjunto de regras aplicáveis apenas aos comerciantes para facilitar o tráfico comercial, a grande capacidade de adaptação às novas práticas do mercado e ao universalismo quanto às formas e ao objeto normatizados ${ }^{65}$. Essa característica assume maior importância nos dias de hoje, quando a globalização dos mercados, a troca contínua de informações e tecnologia exige uma maior uniformização de regras e práticas, para facilitar o comércio entre as nações.

A importância que as atividades das empresas privadas e o comércio possuem para produção de riquezas para um país é analisada por Cinzia

Parágrafo único. É assegurado a todos o livre exercício de qualquer atividade econômica, independentemente de autorização de órgãos públicos, salvo nos casos previstos em lei."

${ }^{62}$ FRONTINI, Paulo Salvador. A Atividade Negocial e seus Pressupostos Econômicos e Políticos, Revista de Direito Mercantil, Industrial, Econômico e Financeiro, vol. 18. São Paulo: Revista dos Tribunais, Ano XIV, Nova Série, 1975, pág. 33.

${ }^{63}$ Art. $3^{\circ}$ da Constituição Federal de 1988.

${ }^{64}$ A Atividade Negocial..., págs. 34 e 35.

${ }^{65}$ REALE, Miguel. Lições Preliminares..., pág. 308. 
Gamba $^{66}$ sob a perspectiva econômica do Direito Societário, que ressalta que os Poderes Legislativos e Judiciário deveriam ainda ter por escopo principal a criação de um sistema de regras que contenham termos abertos e que possibilitem às partes envolvidas nas operações econômicas, diminuir os custos de transação envolvidos na solução de controvérsias.

Com relação às sociedades por ações, diversos princípios estão refletidos na Lei 6.404, que estabelecem os preceitos fundamentais que regem esse tipo de sociedade e que servem de fundamento e guia para a interpretação de seus dispositivos. Dentre eles, os princípios da separação patrimonial entre a sociedade e seus acionistas, o poder atribuído aos majoritários para tomada de decisões e orientação da companhia para atingir os fins previstos em seu Estatuto Social e o reconhecimento da função social da empresa. Desses princípios decorrem outros que os complementam e regulam, como a criação de direitos fundamentais dos acionistas que não podem ser afastados pelo Estatuto Social ou a Assembléia Geral, os limites, internos e externos, para exercício do poder de controle, a exigência de que os acionistas e administradores devem agir, uns com os outros com boa-fé e lealdade, a intangibilidade do capital social como garantia dos terceiros e credores e a publicidade dos atos societários. Cada um desses princípios sofre desdobramentos e criam regras específicas de conduta para os acionistas controladores, os acionistas em geral e os administradores da companhia. Desta forma, se exige que o acionista controlador não abuse do poder de que é titular em prejuízo dos demais acionistas, dos trabalhadores e da comunidade em que a companhia atua; os acionistas também não podem abusar de seu direito de voto ou exercê-lo para obtenção de um fim ilegítimo, os acionistas e administradores não podem votar ou atuar em conflito de interesses com a companhia para obtenção de benefícios pessoais, estando esses princípios expressos no texto da Lei. No entanto, como discorreremos em seguida, o conteúdo das normas que concretizam tais princípios, é aberto ou "incompleto", justamente para possibilitar sua adaptação aos casos concretos, não estabelecendo hipóteses exaustivas justamente para que o julgador leve em consideração os conceitos e princípios aplicáveis as sociedades por ações.

${ }^{66}$ Diritto Societario..., pág. 29: "Alla luce di questa prospettiva, è possibile altresì comprendere quale dovrebbe essere il ruolo del diritto societario, sai di formazione legislativa che di matrice giurisprudenziale. Secondo la teoria della rete di contratti, le norme prodotte dal legislatore e le regole adottate dalle corti dovrebbero avere come unico scopo quello di creare un sistema de regole-standard che le parti possono utilizzare riducendo drasticamente i costi che richiederebbe una contrattazione specifica sui vari punti dell'accordo." 
Assim, o artigo 115 da Lei das S.A. determina como abusivo o voto proferido por um acionista, independentemente de sua participação no capital social, que tenha por fim causar dano à companhia ou a outros acionistas ou obter para si ou para outrem, vantagem a que não faz jus e de que resulte ou possa resultar, prejuízo para a companhia ou para outros acionistas. Nessas hipóteses, o acionista responde pelos danos causados pelo exercício abusivo do direito de voto, ainda que seu voto não tenha prevalecido ( $\$ 3^{\circ}$ do artigo 115). A análise desse artigo, como será discutido posteriormente, deve ser feita de forma integrada com o disposto no artigo 187 do Código Civil que determina que o exercício de um direito não pode exceder “...manifestamente os limites impostos pelo seu fim econômico ou social, pela boa-fé ou pelos bons costumes."

$\mathrm{O} \S 1^{\circ}$ deste artigo trata da existência de conflito de interesses entre o acionista e a companhia e determina o impedimento do acionista votar nas deliberações relativas ao laudo de avaliação de bens conferidos pelo acionista à sociedade e nas deliberações relativas à aprovação de suas contas como administrador. Nessas hipóteses, o voto do acionista que tiver interesse conflitante, sequer deverá ser computado.

A parte final do $\S 1^{\circ}$ do artigo 115 prevê, de modo genérico, que um acionista também estará impedido de votar em quaisquer outras deliberações que possam beneficiá-lo de modo particular ou em que tiver interesse conflitante com a companhia. Como nem sempre será possível identificar o benefício particular que o acionista pretende ao pronunciar seu voto ou o interesse conflitante, se a situação não for identificada antes da deliberação, e o acionista participar da votação da matéria em questão, contribuindo para sua aprovação ou rejeição, a deliberação será anulável e o acionista responderá pelos danos causados e será obrigado a transferir para a companhia as vantagens que tiver auferido, nos termos do $\S 4^{\circ}$ do artigo $115^{67}$.

\footnotetext{
${ }^{67}$ Adiante desenvolveremos a análise das situações que envolvem o exercício de voto abusivo ou em conflito de interesses entre o acionista e a companhia e as conseqüências, para a administração da sociedade, das decisões tomadas por acionistas nestas situações.
} 
$\mathrm{O}$ artigo 116, em conjunto com o art. 117, estabelecem que o poder de controle deve ser exercido pelo controlador com o fim de fazer a companhia buscar seu objeto e cumprir sua função social, observando os deveres e responsabilidades que possui para com os demais acionistas da companhia, os que nela trabalham e para com a comunidade em que atua, cujos direitos e interesses deve lealmente respeitar e atender, respondendo pelos danos causados por atos praticados com abuso de poder de controle. O art. 117 prevê também, de forma exemplificativa, hipóteses de exercício abusivo do poder de controle.

Os artigos 153 a 157 tratam dos deveres e responsabilidades dos administradores, estabelecendo os princípios que norteiam sua atuação e comportamento o exercício de suas funções. Esses princípios estabelecem guias para o comportamento dos administradores, que refletem as expectativas e a confiança depositadas pelos acionistas nos administradores eleitos para gerir o patrimônio social. Devem os administradores, portanto, nos termos desses artigos, "empregar no exercício de suas funções, o cuidado e diligência que todo homem ativo e probo costuma empregar na administração de seus próprios negócios", "exercer as atribuições que a lei e o estatuto the conferem para lograr os fins e no interesse da companhia, satisfeitas as exigências do bem público e da função social da empresa", "servir com lealdade à companhia e manter reserva sobre os seus negócios", não "intervir em qualquer operação social em que tiver interesse conflitante com o da companhia”, cientificar os demais administradores do seu impedimento e fazer consignar na ata da reunião do órgão a que pertence, "a natureza e extensão de seus interesses" e, nos casos de administradores de companhias abertas, devem estes declarar, ao firmar o termo de posse, os valores mobiliários da companhia de que sejam titulares.

Assim, os artigos 115 a 117 e 153 a 157 estabelecem princípios gerais que norteiam e limitam o comportamento dos acionistas em geral, dos controladores e dos administradores da companhia. Algumas das situações em que a conduta prejudicial à companhia torna-se mais evidente, estão exemplificadas nesses artigos e servem como parâmetro para análise e identificação de outras situações que possam acarretar prejuízos àqueles que a lei procura proteger (a própria companhia, os demais acionistas, os acionistas minoritários, os trabalhadores, terceiros envolvidos e a comunidade em que a companhia atua). 
A identificação de alguma das situações previstas nos artigos acima citados e a aplicação de penalidades pela conduta vedada pela lei, depende da análise do comportamento daquele que praticou o ato e dos fatos que envolvem a situação analisada para que se possa determinar se, de fato, foi praticado algum ato contrário aos interesses da companhia ou no qual ocorreu abuso do direito ou de poder. A lei não define expressa e exaustivamente todas as hipóteses de ocorrência desses casos, justamente para que aquele que vai analisar a situação, seja ele o juiz ou autoridade administrativa, árbitro ou mediador, possa apreciar a situação concreta e determinar se ocorreu a inobservância de algum dever ou abuso de um direito ou poder e, portanto, houve transgressão do princípio geral de conduta.

Desta forma, como ressaltado pelos autores do projeto da Lei das S.A. ${ }^{68}$, a definição dos parâmetros de conduta e dos princípios, sem procurar exaurir as hipóteses contidas na norma, é intencional e oferece a flexibilidade necessária para que os juízes possam analisar cada caso e oferecer a melhor solução para a situação apresentada, conferindo assim, ao mesmo tempo, flexibilidade às normas para que elas possam se adaptar às mudanças de comportamento, práticas de mercado e operações negociais que interferem na administração das S.A., e maior responsabilidade àqueles que vão analisar a situação apresentada e interpretar aquele conceito, dando-lhe significado e, aplicando, se for o caso a penalidade ao caso concreto.

Por esse motivo, o papel do Judiciário e dos órgãos reguladores é fundamental para oferecer segurança àqueles que atuam nessa área. A falta de uma linha interpretativa clara por parte dos tribunais causa insegurança, principalmente aos acionistas minoritários e investidores afastados do poder de controle da companhia e abre espaço para comportamentos oportunísticos dos controladores e administradores.

Esse problema é ainda maior nas jurisdições em que o mercado de capitais e as condições empresariais ainda estão se desenvolvendo, o que leva as instituições que atuam nessas áreas a exercer papel fundamental na evolução do direito empresarial. Como apontaram Bernard Black e Reinier Kraakman ${ }^{69}$, em países que

\footnotetext{
${ }^{68}$ A Lei das S.A.,..., pág. 213.

${ }^{69}$ A Self-Enforcing Model..., pág. 02.
} 
possuem um sistema de direito empresarial mais desenvolvido, a legislação empresarial é combinada com outras forças, legais, mercadológicas e culturais, que constrangem as ações dos administradores e dos acionistas controladores, buscando alcançar um equilíbrio sensível entre a necessidade de flexibilidade dos administradores da companhia, para atender rapidamente as mudanças negociais do mercado, a necessidade das companhias em diminuir o custo de transação para acesso ao mercado de capitais, a necessidade dos grandes investidores de monitorar os atos dos administradores e a necessidade dos pequenos investidores de proteção contra atos praticados em conflito de interesses por administradores e acionistas controladores. Quanto mais eficaz for o sistema, maior será a segurança dos investidores na correta condução dos negócios sociais, o que irá contribuir para diminuição do custo de captação de recursos da empresa no mercado. Os autores defendem que, nesse sistema, a legislação positiva possui um papel reduzido na regulação do mercado ${ }^{70}$.

Em países de economia emergente, a inexistência ou pouca expressão desses componentes extra-jurídicos que exercem influência no meio empresarial, exige que a legislação societária exerça um papel fundamental na regulação desse mercado e, portanto, a eficácia de sua aplicação é central na avaliação da eficiência do sistema. No entanto, a demora e pouca especialização na matéria dos tribunais desses países diminui a confiança do mercado e impede seu desenvolvimento e atração de recursos ${ }^{71}$.

Katharina Pistor e Chenggang $\mathrm{Xu}^{72}$ propõem uma abordagem econômica para a análise da interpretação e cumprimento das regras contidas nesses princípios e padrões gerais de comportamento existentes na legislação societária e do

${ }^{70}$ A Self-Enforcing Model..., pág. 02: "In developed countries, corporate law combines with other legal, market and cultural constraints on the actions of corporate managers and controlling shareholders to achieve a sensible balance among these sometimes competing needs. Corporate law plays a relatively small, even 'trivial' role."

${ }^{71}$ A Self-Enforcing Model..., pág. 09: "Corporate law in an emerging economy must address a broader set of goals, and operate within a far less evolved market and legal infrastructure, than corporate law in a developed economy. The paradoxical consequence is that the protective function of corporate law becomes more important precisely when fewer other resources are available to support that function."

${ }^{72}$ Os autores são professores, respectivamente, da Columbia Law School e London School of Economics \& Political Science e escreveram uma série de artigos desenvolvendo uma análise jurídica e econômica das conseqüências resultantes da "incompletude" da lei. Vários desses artigos estão disponíveis no site http://ssrn.com, dentre eles "Incomplete Law - A Conceptual and Analytical Framework - and its Application to the Evolution of Financial Market Regulation", "Fiduciary Duty in Transition Civil Law Jurisdictions - Lessons from the Incomplete Law Theory" e "Law Enforcement under Incomplete Law: Theory and Evidence from Financial Market Regulation", citados neste trabalho. 
mercado de capitais e seu impacto no desenvolvimento empresarial e do mercado de capitais em países em diferentes estágios de desenvolvimento.

Os autores entendem que uma lei pode ser considerada incompleta quando nela faltam aplicações legais relevantes ou se essas aplicações estiverem nela estipuladas de forma ambígua. Nessas hipóteses, nem as pessoas para quem são dirigidas tais normas e nem aqueles que devem aplicar a norma podem prédeterminar se um ato ou ação em particular está abrangido pelo escopo da lei e, portanto, deve sofrer suas sanções ${ }^{73}$.

Nas leis consideradas completas, todas as ações potencialmente danosas estão nela previstas e mediante interpretação simples da norma, as pessoas envolvidas podem concordar com o seu significado e se a situação em questão está ou não enquadrada dentre as hipóteses legais. Assim, mediante apresentação das evidências de um determinado comportamento ou ação, a lei é aplicável. Nesses casos, o sistema legal tem como principal problema determinar quais são as sanções adequadas para a situação enquadrada na lei e o grau de esforço, inclusive financeiro, que deverá ser despendido para garantir o cumprimento da lei de forma a impedir sua violação ${ }^{74}$.

Em determinadas áreas do direito, como o Direito Penal e o Direito Tributário, é fundamental que existam essas normas completas, que prevêem de forma restrita a fattispecie que regulam e especificam as sanções para o caso de descumprimento dos deveres impostos. Nesses casos, a determinação exaustiva das hipóteses abrangidas pela norma serve como proteção dos direitos individuais face ao Poder normativo do Estado.

Essa determinação exaustiva da lei também gera um grau maior de segurança jurídica, na medida em que todas as pessoas envolvidas na situação regulada têm certeza quanto ao conteúdo da norma, sua interpretação e aplicação pelos

\footnotetext{
${ }^{73}$ Law Enforcement under Incomplete Law: Theory and Evidence from Financial Market Regulation. Londres: Suntory and Toyota Internacional Centres for Economics and Related Disciplines - Theoretical Economics Discussion Paper, dezembro de 2002. Disponível em: 〈http://ssrn.com/abstract=396141〉, acesso em 12.dez.2008, pág. 02.

${ }^{74}$ Law Enforcement..., pág. 05.
} 
tribunais. Kelsen ${ }^{75}$, analisando o grau de poder conferido aos tribunais para criar normas individuais através de decisões judiciais e normas gerais, conclui que, nos sistemas em que a "...produção de normas jurídicas gerais está completamente centralizada, quer dizer, é reservada a um órgão legislativo central os tribunais limitam-se a aplicar aos casos concretos, nas normas individuais a produzir por eles, as normas gerais produzidas por esse órgão administrativo.". Assim, não obstante conferirem um grau de flexibilidade menor ao judiciário do que no caso das normas gerais, as normas específicas oferecem, "...em contrapartida, a vantagem da segurança jurídica, que consiste no fato de a decisão dos tribunais ser até certo ponto previsível e calculável, de os indivíduos submetidos ao Direito poderem orientar-se na sua conduta pelas previsíveis decisões dos tribunais."

Por outro lado, as normas entendidas como completas possuem uma flexibilidade menor para se adequar às alterações sociais e econômicas que influenciam as hipóteses nelas contidas. Qualquer alteração em seu conteúdo depende de um ato legislativo que amplie ou restrinja sua abrangência para que não haja dúvidas quanto à aplicação dessa norma às hipóteses e às pessoas que se pretende sejam por ela reguladas ${ }^{76}$.

No caso das responsabilidades e obrigações a que estão sujeitos os acionistas, controladores e administradores, isto significaria que os legisladores

\footnotetext{
${ }^{75}$ Teoria Pura..., pág. 268.

${ }^{76}$ PISTOR, Katharina e XU, Chenggang. Incomplete Law - A Conceptual and Analytical Framework and its Application to the Evolution of Financial Market Regulation. Journal of International Law and Politics, Vol. 35, No. 4, pp. 931-1013, 2003. <Disponível em: http://ssrn.com/abstract_id=310588>, acesso em 25.jan.2008, pág. 12, narram o processo e dificuldades porque passaram os tribunais alemães, ingleses e norte-americanos para adequação e interpretação de normas, que a princípio seriam completas, às mudanças tecnológicas, tomando por exemplo a disseminação do uso da energia elétrica e o início da ocorrência de roubo de energia elétrica, quando não existia expressamente essa previsão na lei: "Most legal systems prohibit theft. Theft is usually defined as the appropriation of an asset that is owned by another person by breaching his or her possession. When electricity was invented and some people simply hooked their households up to the electricity lines instead of connecting officially and paying their bills, the question arose, whether this constituted a theft. For the German Supreme Court (Reichsgericht), which had to decide this issue in the late nineteenth century, the key question was whether electricity was an 'asset' (eine Sache) as defined by law. It acquitted, because it denied the asset quality of electricity and argued that the extension of the existing theft provision would amount to lawmaking by analogy, which would be in violation of the nulla poena sine lege principle. The legislative response was to insert a new provision in the code that dealt specifically with appropriating energy. When confronted with similar cases, English and U.S. courts argued that the key issue was not the asset quality of whatever is appropriated, but the fact that something can be appropriated. But the matter remained sufficiently incomplete to bring a case to the NY Supreme Court as late as 1978. By that time, New York had adopted a provision that made 'theft of services' a punishable offense, which covers actions from using public transport without pay to appropriation of energy or other sources."
} 
deveriam antever absolutamente todas as situações violadoras de tais responsabilidades e obrigações e determinar as sanções e nível de punição aplicáveis para cada situação. O Poder Judiciário deveria então verificar se a situação trazida a seu conhecimento está expressamente prevista na lei e aplicar a penalidade nela prevista.

Nas leis incompletas, a interpretação e aplicação para o caso concreto requer um trabalho mais elaborado, cabendo ao aplicador da lei verificar, mediante análise dos fatos trazidos a seu conhecimento, se uma determinada situação enquadra-se dentro de seus objetivos econômicos e sociais ${ }^{77}$.

Em se tratando de normas que regulam o Direito e o mercado de capitais, é essencial que haja flexibilidade na interpretação das normas aplicáveis, para que a legislação possa adaptar-se às mudanças sociais, econômicas e tecnológicas que influenciam diretamente o comportamento dos agentes nessas áreas.

Por outro lado, dependendo da dificuldade de determinação de seu conteúdo, a existência de normas incompletas pode causar insegurança, abrindo espaço para discussão quanto à sua aplicação e conteúdo. Nesses casos, o legislador, os destinatários da norma e até mesmo os juízes podem discordar quanto à interpretação e aplicação correta da norma ao caso concreto, o que diminui a eficácia de sua $\operatorname{aplicação~}^{78}$.

${ }^{77}$ Law Enforcement..., pág. 04

${ }^{78}$ Law Enforcement.... Pág. 8 e seguintes, os autores relatam o caso Peak vs. Overand and Gurney and al, ocorrido na Inglaterra de que envolvia a interpretação da regra de informação ao mercado na emissão de valores mobiliários, vigente à época, no qual os administradores e controladores da empresa Overand and Gurney, após alguns anos de prejuízo, constituíram a O\&G Co., uma joint stock company (em que os acionistas têm responsabilidade ilimitada pelas obrigações da empresa), atraindo investidores no mercado de capitais. O prospecto através do qual fizeram o lançamento das ações no mercado informava que a nova empresa O\&G Co. iria conduzir os negócios da Overand and Gurney, pagando £500,000 pelo good will desta última. No entanto, os diretores da $\mathrm{O} \& \mathrm{G}$ Co. não informaram a existência de um contrato no qual se determinava a manutenção da Overand and Gurney até o pagamento de seus débitos, ficando reservado o direito, aos diretores, de liquidar a primeira empresa quando entendessem conveniente. Após captar recursos no mercado, os administradores depositaram £500,000 em uma conta da Overand and Gurney em pagamento do good will desta empresa. Cerca de um ano após sua constituição a O\&G Co. tornou-se insolvente e foi liquidada. No processo movido pelos acionistas da O\&G Co. lesados, estes defendiam que os diretores da Overand and Gurney, que eram os mesmos da O\&G Co., tinham a obrigação de revelar ao mercado a existência do contrato que lhes permitia dissolver essa empresa e, em razão disso, a operação de emissão de ações da O\&G Co. foi fraudulenta, devendo os administradores da Overand and Gurney ser pessoalmente responsabilizados e arcar com as perdas sofridas pelos acionistas da O\&G Co. Como as regras vigentes à época determinavam que os administradores tinham o dever de apresentar informações relevantes da companhia, relativas à emissão realizada, mas não explicitavam que os agentes envolvidos na emissão de valores mobiliários tinham a obrigação de levar a conhecimento do 
Aqueles que atuam no mundo jurídico reconhecem a existência de princípios e conceitos gerais como necessária à flexibilização do conteúdo das normas às mudanças sociais e econômicas. A aplicação concreta de tais princípios e padrões, assim como as conseqüências, para aplicação da lei, em razão da existência de normas amplas há muito tempo tem sido estudada pela doutrina ${ }^{79}$. No entanto, ao estudarmos especificamente a interpretação e aplicação prática de tais princípios e conceitos gerais no campo do Direito Societário, verificamos que a ausência de jurisprudência sólida e coerente e a pouca especialização dos juízes nessa área, não permite conceber, ainda, no Direito Brasileiro, as linhas de interpretação aplicáveis a cada um desses princípios e conceitos, de forma a servir de guia de conduta aos controladores e administradores e para facilitar a fiscalização da administração da companhia pelos minoritários e terceiros afetados.

Um dos meios que o sistema legal possui para garantir o cumprimento e alcance dos objetivos de uma lei incompleta, é aumentando o nível de punição aplicável para aqueles que praticam os atos que a lei incompleta quer impedir que ocorram. Katharina Pistor e Chenggang Xu alertam que o aumento do nível de punição para esse tipo de norma, ao invés de prevenir a ocorrência de tais atos e comportamentos, pode acarretar punições excessivas, desproporcionais ao prejuízo causado $^{80}$.

O Poder Judiciário é o destinatário que irá interpretar as normas e aplicá-las a um caso concreto, constituindo um verdadeiro poder normativo residual.

mercado todos os contratos celebrados que pudessem afetar a decisão dos investidores adquirir valores mobiliários daquela companhia, o ponto principal da controvérsia versou sobre a obrigatoriedade de os administradores da O\&G Co. revelarem a existência do contrato secreto ao mercado. E concluem: "Thus, O\&G Co. may not face liability even when harm has been done (investors lost their money) and evidence has been established (the secret agreement was not disclosed), because they may not be liable for failing to disclose certain information. If lawmakers and law enforces cannot agree on the precise meaning of the law, issuers - or in this case, the directors of O\&G Co. - have a strong case arguing that directors did not have any obligations to disclose the secret agreement and therefore could not have violated them (this is precisely what the attorneys of Overand and Gurney argued and the court held for them)."

${ }^{79}$ FERRAZ JR., Tercio Sampaio, Introdução ao Estudo do Direito: Técnica, Decisão, Dominação. São Paulo: Atlas, 1990, pág. 121 estabelece como um dos critérios para determinação do tipo da norma, o grau de abstração de sua matéria (fattispecie): "A descrição da hipótese da situação de fato, sobre a qual incide a consequiência, pode ser abstrata, na forma de um tipo ou categoria genérica, ou pode ser singular, na forma de um conteúdo excepcionado. A distância entre o genérico e o singular, tomados como termos mutuamente relativos, admite gradações. Dependendo do grau de abstração podemos então distinguir entre normas gerais-abstratas (isto é, gerais pela matéria), normas especiais e normas excepcionais."

${ }^{80}$ Law Enforcement..., pág. 02. 
Como conclui Eros Grau ${ }^{81}$, são os juízes que determinam os conteúdos normativos das disposições, dando significado às normas: "Por isso as normas resultam da interpretação e podemos dizer que elas, enquanto disposições, não dizem nada - elas dizem o que os intérpretes dizem que elas dizem. O intérprete dotado de poder suficiente para criar as normas, a partir delas construindo, em cada caso, a norma de decisão, é o "intérprete autêntico", no sentido conferido a essa expressão por Kelsen (1979/469 e ss.) - isto é, fundamentalmente o juiz."

Sob a perspectiva da análise econômica do direito, ganha destaque o problema da atuação coerente e eficaz do Judiciário como meio de fortalecimento do mercado de capitais e realização de investimentos no país. A interpretação e aplicação das leis pelos tribunais desenvolve e completa o conteúdo das normas positivadas existentes, conferindo-lhes eficácia ${ }^{82}$. A solução do conflito real envolvendo a companhia e seus sócios ou terceiros e a aplicação de sanções práticas adequadas, preserva a eficiência da iniciativa empresarial privada e influencia o comportamento dos indivíduos envolvidos na administração das sociedades por ações, desestimulando o comportamento oportunístico e incentivando a boa-fé e a cooperação entre as partes o que diminui os custos envolvidos na contratação e realização de investimentos nas sociedades por ações e no mercado de capitais ${ }^{83}$.

No entanto, como ressaltamos acima, esse poder normativo somente pode ser exercido pelo Poder Judiciário, na grande maioria das vezes, após ocorrência do dano e mediante provocação de uma das partes, para manter isenção de julgamento em relação às partes envolvidas.

Os autores concluem assim que, além da atuação dos tribunais, necessária para atribuir significado para as situações que não estejam expressamente previstas na lei mas que fazem parte do seu escopo, uma forma institucional de garantir o cumprimento das leis incompletas, dentro do Direito empresarial e do mercado de capitais, é através da introdução de um agente regulador, com competência para atuar de

${ }^{81}$ O Direito Posto..., pág. 95.

${ }^{82}$ BLACK, Bernard e KRAAKMAN, Reinier, A Self-Enforcing Model..., pág. 14: "Just as the criminal law deters as long as the police catch some criminals, the corporate law can deter misbehavior as long as some misdeeds are remedied in the courts."

${ }^{83}$ GAMBA,Cinzia. Diritto Societario..., pág. 195. 
forma pró-ativa e iniciar um procedimento administrativo para aplicação da lei ao caso concreto. Ao contrário dos tribunais, que somente se manifestam quando e se provocados, na grande maioria das vezes, após a ocorrência do dano, tais agentes teriam a capacidade de iniciar de forma independente um procedimento para apuração ou para impedir a ocorrência dos fatos que a lei procura impedir ${ }^{84}$.

Os órgãos administrativos reguladores, por outro lado, têm competência para, não apenas interpretar a norma dentro de sua área de atuação, exercendo um poder legislativo residual interpretativo, como também iniciar um processo investigativo, independentemente de provocação de uma das partes, fiscalizando os agentes do mercado e intervindo, quando necessário, para apuração da ocorrência de um ato ou conduta contrário às normas aplicáveis. Além disso, a especialização das pessoas que trabalham nesses órgãos, facilitaria a identificação de tais situações e a imposição de penalidades, permitindo a adaptação das regras positivas a novas situações decorrentes das práticas de mercado mais rapidamente ${ }^{85}$.

A análise quanto à conveniência e necessidade de criação de um órgão regulador administrativo, na opinião desses autores, deve levar em consideração os custos envolvidos com sua criação e funcionamento, comparativamente ao tamanho do mercado fiscalizado, a segurança trazida àqueles que atuam naquela área do Direito e aos benefícios que essa fiscalização trará ao impedir ou ao menos diminuir a ocorrência de prejuízos ao mercado em que atua.

Katharina Pistor e Chenggang $\mathrm{Xu}^{86}$ defendem ainda que, do ponto de vista econômico, a criação de um órgão administrativo regulador poderá ser benéfico para aquela área do Direito que necessita de fiscalização, ao exercer de forma

${ }^{84}$ Law Enforcement..., pág. 02.

${ }^{85}$ Neste sentido, PISTOR, Katharina e XU, Chenggang, Law Enforcement..., pág. 32: "The foregoing analysis has shown that regulators emerged in response to deterrence failure caused by incompleteness of law. Regulators hold both residual lawmaking and law enforcement power. Their residual lawmaking power enable them to adjust rules in response to changes in market practice or otherwise result in extensive litigation. Their residual law enforcement power enable them to enforce the law proactively, i.e. to intervene independent of whether or not others, such as the injured party, or a party that is likely to be injured if an action is not enjoined, has taken any action. Unlike courts that are passive and purely reactive enforcers, regulators can act on their own action."

${ }^{86}$ Law Enforcement..., pág. 33: "Our model predicts that given that law is incomplete, regulators as proactive law enforcers are superior to courts when undeterred action can cause substantial negative consequences and when these consequences outweigh the cost of mistakes in regulation". 
pró-ativa a fiscalização e regulação de uma área do Direito, quando as condutas ilícitas dos agentes envolvidos causam prejuízos e conseqüências negativas substanciais em relação ao controle puramente jurisdicional daquela área, justificando os custos envolvidos na criação desse órgão.

Um exemplo dessa agilidade de atuação de órgãos administrativos reguladores quando da ocorrência de uma situação potencialmente prejudicial a acionistas e investidores, verificado no Brasil, no final do ano 2008, ocorreu com a aprovação, pelo Colegiado da CVM, em 17.10.2008, da Deliberação $n^{\circ}$ 550, dispondo sobre a sobre a apresentação de informações dos instrumentos financeiros derivativos utilizados por companhias de capital aberto, em nota explicativa às informações trimestrais divulgadas ${ }^{87}, \operatorname{logo}$ em seguida à divulgação de enormes

${ }^{87} \mathrm{O}$ art. $1^{\text {o }}$ dessa Deliberação prevê: "Art. $1^{\mathbf{0}}$ As companhias abertas devem divulgar, em nota explicativa específica, informações qualitativas e quantitativas sobre todos os seus instrumentos financeiros derivativos, reconhecidos ou não como ativo ou passivo em seu balanço patrimonial." Em razão das notícias divulgadas informando a existência de outras companhias de capital aberto que teriam sofridos grandes prejuízos pela contratação de instrumentos financeiros de alto risco, o Colegiado da CVM

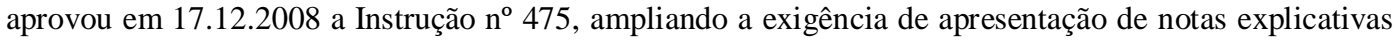
detalhando todos os instrumentos financeiros de alto risco contratos pela empresa, incluindo "os contratos a termo, swaps, opções, futuros, swaptions, swaps com opção de arrependimento, opções flexíveis, derivativos embutidos em outros produtos, operações estruturadas com derivativos, derivativos exóticos e todas as demais operações com derivativos, independente da forma como sejam contratados". Nessa exigência, as companhias devem obedecer às seguintes instruções: "Art. 10 As companhias abertas devem divulgar, em nota explicativa específica, informações qualitativas e quantitativas sobre todos os seus instrumentos financeiros, reconhecidos ou não como ativo ou passivo em seu balanço patrimonial. $\S 1^{\circ}$ As notas explicativas de que trata o caput devem ser verdadeiras, completas e consistentes. $\S 2^{\circ}$ As notas explicativas de que trata o caput devem ser escritas em linguagem clara, objetiva e concisa. $\S 3^{\circ}$ As notas explicativas de que trata o caput devem permitir aos usuários avaliarem a relevância dos instrumentos financeiros, especialmente os instrumentos financeiros derivativos para a posição financeira e os resultados da companhia, bem como a natureza e extensão dos riscos associados a tais instrumentos. $\S 4^{\circ}$ As informações quantitativas da nota explicativa de que trata o caput devem ser apresentadas em forma de tabela observando, no que for aplicável, o exemplo constante do Anexo I. $\S 5^{\circ}$ A tabela de apresentação das informações quantitativas de que trata o $\S 4^{\circ}$ deve segregar instrumentos financeiros derivativos especulativos daqueles destinados à proteção de exposição a riscos (hedge). $§ 6^{\circ}$ Devem ser divulgados quaisquer outros dados necessários para que os usuários das demonstrações financeiras tenham condições de avaliar as informações quantitativas." Além disso, devem ser publicados quadros demonstrativos de análise de sensibilidade, para cada tipo de risco de mercado considerado relevante pela administração, originado por instrumentos financeiros, ao qual a entidade esteja exposta na data de encerramento de cada período, incluídas todas as operações com instrumentos financeiros derivativos. Nos termos dos parágrafos $1^{\circ}$ e $2^{\circ}$ do artigo $3^{\circ}$ dessa Instrução, constam as informações que deverão constar desses quadros demonstrativos: " $\$ 1^{\circ} \mathrm{O}$ quadro demonstrativo de análise de sensibilidade de que trata o caput deve ser- divulgado e elaborado da seguinte forma: I - identificar os tipos de risco que podem gerar prejuízos materiais para a companhia, incluídas as operações com instrumentos financeiros derivativos originadoras desses riscos; II - discriminar os métodos e premissas usadas na preparação da análise de sensibilidade; III - definir o cenário mais provável, na avaliação da administração, além de 2 (dois) cenários que, caso ocorram, possam gerar resultados adversos para a companhia; IV - estimar o impacto dos cenários definidos no valor justo dos instrumentos financeiros operados pela companhia; e V - elaborar o demonstrativo de análise de sensibilidade em forma de tabela, considerando os instrumentos financeiros relevantes, inclusive os derivativos, e os riscos selecionados, em linhas, e os cenários definidos, em colunas. $\S 2^{\circ} \mathrm{Na}$ definição dos cenários de que trata o inciso III do $\S 1^{\circ}$ devem ser, 
prejuízos causados a duas grandes companhias de capital aberto nacional, pela utilização de instrumentos financeiros derivativos de alto risco, em razão da inversão brusca no mercado de ações de cambial.

Ainda considerando a necessidade de complementação e finalização da norma jurídica e do tímido desenvolvimento doutrinário e jurisprudencial da matéria no Brasil, que pouco contribuiu até o momento para a criação de linhas de interpretação e definição dos termos e parâmetros aplicáveis, é importante considerar a experiência estrangeira com o desenvolvimento de institutos e linhas de interpretação que podem auxiliar na compreensão do problema no Brasil. Os diferentes contextos culturais, econômicos e sociais de cada país devem ser ponderadas para aplicação desses institutos e adoção de linhas de interpretação. Como concluíram Bernard Black e Reinier Kraakman ${ }^{88}$ nos estudos versando sobre a eficácia e aplicabilidade de normas jurídicas societárias e de mercado de capitais, em países em diferentes estágios de desenvolvimento econômico e social, cinco aspectos do contexto de um país são essenciais para determinar os princípios que deverão ser adotados para regrar essas áreas do Direito: (a) os objetivos da legislação societária; (b) a sofisticação do mercado de capitais e instituições relacionadas; (c) a sofisticação e confiança das instituições legais; (d) a estrutura de propriedade do capital das companhias abertas; e (e) as expectativas culturais dos participantes das atividades empresariais.

No entanto, independentemente do contexto social, econômico e cultural de um país, os problemas enfrentados nas sociedades anônimas, envolvendo a necessidade de proteção dos acionistas e terceiros relacionados, em face da necessidade de garantir aos administradores e controladores autonomia para tomada de decisões, observados os deveres a que devem obedecer, como administradores de patrimônio

necessariamente, utilizadas: I - uma situação considerada provável pela administração e referenciada por fonte externa independente (ex.: preços de contratos futuros negociados em bolsas de valores e ou mercadorias e futuros); II - uma situação, com deterioração de, pelo menos, $25 \%$ (vinte e cinco por cento) na variável de risco considerada; e III - uma situação, com deterioração de, pelo menos, $50 \%$ na variável de risco considerada." Essas medidas foram necessárias para permitir aos acionistas e terceiros tomar conhecimento e obter informações detalhadas sobre a utilização desses instrumentos e seu impacto nos resultados da companhia, para que estes possam fazer a análise de risco de seus investimentos e da situação da sociedade, e tomar decisões conscientes e informados da situação da companhia com que se relacionam. Antes da aplicação dessas normas, muitos acionistas foram prejudicados em razão das perdas sofridas pelas companhias, decorrentes da alteração abrupta do mercado de câmbio.

${ }^{88}$ A Self-Enforcing Model..., pág. 07 e BLACK, Bernard, Strenghtening Brazil's Securities Markets. Stanford Law School, Out.2000. Working Paper No. 205. Disponível em: <http://ssrn.com/abstract_id=247673>. Acesso em 27.dez.2008. 
alheio, são muito semelhantes ${ }^{89}$. Desta forma, não obstante a diferença entre os sistemas jurídicos continental europeu e da common $\operatorname{law}^{90}$, a análise das soluções e institutos criados e das fontes de direito de países estrangeiros oferece contribuição importante para o desenvolvimento do Direito Empresarial em geral, acrescentando experiências que contribuem para uma abordagem mais completa do problema envolvendo a intervenção judicial das sociedades por ações.

${ }^{89}$ Como aponta ZANINI, Carlos Klein, A Doutrina dos "Fiduciary Duties" no Direito Norte-Americano e a Tutela das Sociedades e Acionistas Minoritários frente aos Administradores das Sociedades Anônimas. RDM, vol. 109. São Paulo: Revista dos Tribunais, jan/mar 1998, págs. 138 e 140, analisando os deveres impostos aos administradores (duties of management) nos sistemas norte-americano e brasileiro, a diferença entre esses dois sistemas, quanto ao enquadramento e regulação desses deveres: "O problema lá experimentado - consistente na identificação do dever especificamente inatendido reproduz-se, portanto, entre nós, observadas, contudo, as diferenças decorrentes da diversidade dos sistemas jurídicos, que fazem com que a identificação seja, aqui, um problema de subsunção do caso concreto à previsão normativa, e não uma tentativa de assemelhar a situação sub examine a outras versadas em precedentes anteriores. (...) Assim, a riqueza do desenvolvimento do tema dos fiduciary duties no direito norte-americano, aliado à parca elaboração entre nós experimentada, justifica sua escolha para merecer exame destacado, tendo-se presente, aqui, que a existência de previsão legal dentre nós atribui à análise da matéria interesse que vai além da curiosidade acadêmica, servindo o estudo do direito comparado de instrumento para uma melhor compreensão e efetiva aplicação prática do instituto pelo operador do direito."

${ }^{90}$ ASCARELLI, Tulio. A Idéia do Código no Direito Privado e a Tarefa da Interpretação, em Problemas das Sociedades Anônimas e Direito Comparado. Campinas: Bookseller, 2001, pág. 143, aponta a aproximação cada vez maior entre os dois sistemas: "Será útil, talvez, uma última observação relativa ao progressivo avizinhamento entre sistemas condificados e sistemas não-codificados, decorrente da maior importância que adquiriu, nos primeiros, a jurisprudência, a legislação, nos segundos. Os 'precedentes' jurisprudenciais, com efeito, adquiriram, na Europa continental, uma importância, muitas vezes, praticamente decisiva, o que foi também uma conseqüência da unidade jurisprudencial devida à instituição da Cassação francesa e de tribunais semelhantes nos demais paíes. Com isso o sistema da Europa continental aproximou-se, nesse ponto, do sistema inglês. Neste, foi progressivamente aumentando a importância da legislação, paralelamente às profundas transformações do direito privado, nos séculos XIX e XX, e à progressiva transformação democrática da sociedade. Quanto ao sistema norte-americano, neste é menor que no inglês a importância do precedente jurisprudencial e comparativamente maior a da legislação e a tendência à 'consolidação' das leis e até da condificação. Por seu turno, foi-se frisando, no direito anglo-norte-americano, a tendência em encarar sistematicamente a common law e em evidenciar os princípios fundamentais desta. Verificamos, assim, que há, malgrado a subsistência de profundas diferenças, uma aproximação, quanto à técnica jurídica, entre os sistemas codificados e os não-codificados." 


\title{
II.1 - O CONTRATO SOCIAL COMO CONTRATO "INCOMPLETO"
}

\begin{abstract}
Conforme já exposto anteriormente, o contrato social é um contrato plurilateral, que agrega os interesses das diversas partes (os sócios) por ele envolvidos, harmonizando e regulando esses interesses para possibilitar a constituição de um novo ente (a sociedade).
\end{abstract}

O Estatuto Social de uma companhia estabelece as regras principais do relacionamento entre os acionistas, da administração e funcionamento da sociedade e para exercício do poder de controle, dentro da liberdade conferida aos acionistas para criar as regras que entendam aplicáveis àquela sociedade e os princípios determinados pela Lei 6.404/76.

No entanto, no momento de constituição da companhia, não se poderá prever e regrar todas as situações envolvendo os acionistas, o comportamento dos controladores e os rumos das atividades sociais, tendo em vista, inclusive, que estes serão fortemente influenciados pelas alterações do mercado, da economia, da sociedade e pelo cenário político.

A impossibilidade de se prever de forma exaustiva e detalhada, desde o momento da constituição da sociedade, todas as situações que irão ocorrer que a envolverão, e também a seus sócios e administradores, e, ao mesmo tempo, estabelecer as soluções que deverão ser aplicadas a cada caso, torna o contrato social um contrato "incompleto", em comparação com outros tipos de contratos que contém todas as hipóteses que poderão ocorrer e o tratamento a ser aplicado a cada uma delas.

O contrato social estabelece as regras e condições vigentes entre os sócios quando da contratação da sociedade, revelando assim as motivações e interesses de cada um. Essas disposições oferecem as bases sobre as quais deverão ser solucionados os conflitos e sanadas as dúvidas de interpretação das regras do próprio 
contrato social e de condução dos negócios sociais. Como negócio jurídico privado, os sócios têm liberdade para determinar as regras que entendam devam reger as relações internas da sociedade e entre eles, observados os princípios que regem esse tipo de negócio jurídico e a atividade que será desenvolvida pela empresa ${ }^{91}$.

Assim, ainda que se procure pré-determinar todas as consequiências e regras aplicáveis para solução dos conflitos que surgirão, não é possível que essa previsão seja exaustiva, o que vai exigir dos acionistas e daqueles encarregados da solução da controvérsia, seja o Poder Judiciário ou um tribunal arbitral, a interpretação dos princípios contidos no contrato social e na Lei, mediante análise da controvérsia e dos fatos em que ela surgiu, determinando ou não seu enquadramento nos comportamentos vedados em lei ou no Estatuto. Essas "lacunas" do contrato social são inevitáveis. O comportamento das pessoas envolvidas na existência da sociedade e determinantes de sua administração, durante toda a existência da sociedade, é imprevisível e pode ser contrário às regras inicialmente pactuadas.

Cabe aos sócios e administradores da sociedade, e aos juízes, quando não for possível solucionar amigavelmente os conflitos surgidos, interpretar as regras contidas no contrato social, em conjunto com as regras de Direito Societário vigentes, considerando, nessa interpretação, tanto as regras explícitas, que seriam as expressamente contidas no contrato social, como as regras implícitas, que podem ser deduzidas da situação existente à época da elaboração do contrato social e que condicionaram a constituição da sociedade.

Além disso, faz parte da atividade empresarial, a assunção dos riscos inerentes à atividade da empresa, que levarão ao seu sucesso ou insucesso. As taxas de retorno dos investimentos, muitas vezes estão diretamente vinculadas aos riscos empresariais assumidos pelos controladores e administradores o que motiva os acionistas minoritários a aceitar que seus investimentos sejam conduzidos por outras

\footnotetext{
${ }^{91}$ FERRAZ JR., Tercio Sampaio. Introdução..., pág. 134, discorre sobre o princípio da autonomia privada nos negócios sociais, nos seguintes termos: "No direito privado vige, supremamente, o princípio da autonomia privada. Os entes privados gozam desta capacidade de estabelecer normas conforme os seus interesses. Este princípio está na base dos acordos de vontade (como os contratos), mas também dos atos de vontade unilaterais (como a doação). Também eles, contudo, submetem-se à legalidade. Mas não à estrita legalidade: se a lei não lhes proíbe nem lhes obriga a agir, eles podem agir. Há, contudo, outros princípios que limitam essa permissão como o da boa-fé, que protege a confiança e exige a lealdade nos negócios jurídicos."
} 
pessoas, os controladores, que se presumem as mais interessadas no sucesso do empreendimento, por deterem uma participação maior no capital social.

Assim, o que se discute, em um primeiro momento, não é o resultado das decisões tomadas pelos controladores e administradores das companhias mas sim se estes agiram de boa-fé e foram observados os princípios e procedimentos estabelecidos, tanto na Lei 6.404/76, quando no Estatuto Social, que devem nortear a tomada de decisões empresariais para realização do objeto social, voltados sempre para assegurar os interesses da companhia ${ }^{92}$.

O fato do Estatuto Social e a própria Lei das S.A. não preverem todas as situações envolvendo o inobservância desses princípios na condução dos negócios sociais ou um desvirtuamento do comportamento do controlador ou do administrador, ao mesmo tempo que condiz com os princípios gerais envolvendo a atividade empresarial, cria, para os acionistas, especialmente os minoritários, um "constante risco estrutural", como observa Cinzia Gamba ${ }^{93}$, inerente ao princípio majoritário de tomada de decisões.

92 Neste mesmo sentido, reproduzimos trecho de decisão proferida pela Corte de Cassação Italiana, analisada por TERRUSI, Francesco. L'Invalidità delle Delibere Assembleari Della SPA. Giuffrè Editore. Milão: 2007, pág. 150: "Il vizio della deliberazione assembleare, costituito dal cosiddetto eccesso di potere, deve riconoscersi, sendo la giurisprudnza di questa Corte di legittimità, laddove la delibera sia stata adottata a proprio esclusivo vantaggio dai soci di maggioranza di una società di capitali in danno di quelli di minoranza, essendo applicabile in materia l'art. 1375 cod. Civ., in base al quale il contratto deve essere eseguito secondo buona fede, atteso che le determinazioni dei soci durante lo svolgimento del rapporto associativo debbono essere considerate, a tutti gli effetti, come veri e propri atti di esecuzione, perché preordinati alla migliore attuazione del contratto sociale (set. 26 ottobre $1995 \mathrm{n}$. 11151). Nel caso sottoposto all'esame della Corte, la ratio decidendi posta a base dell'annullamento della delibera non è quella appena ricordata, vale a dire la violazione del principio di buona fede nell'esecuzione del contratto sociale, indanno della minoranza dei soci, ma la supposta irrazionalità della determinazione dell'assemblea, per avere la maggioranza agito per finalità contrarie a quelle per le quali era stata costituita. Ora, un vizio di questo tipo non è compreso tra quelli per i quali, a norma dell'art. 2377, il sócio dissenziente può domandare l'annullamento della deliberazione."

${ }^{93}$ Diritto Societário..., pág. 39: "All'interno della compagine sociale, sono infatti attribuiti poteri agli ammnistratori nella direzione dell'ativitá d'impresa e nella scelta delle strategie di gestione; del pari, poteri discrezionali ha anche la maggioranza all'interno dell'assemblea, che assume le deliberazioni sulla base del principio di maggioranza, uno 'strumento consensuale' che permette la ridefinizione e l'integrazione continue del contenuto dell'acordo iniziale. Queste peculiaritá conferiscono alla relazione contrattuale societária uma particolare 'incompletezza', in quanto l'impossibilitá di regolare compiutamente i comportamenti dei soggetti depositari dei poteri espone i contraenti/finanziatori al rischio di subire le conseguenze di comportamenti opportunistici, rivolti cioè al perseguimento di interessi egoistici a danno degli altri contraenti in dispregio degli accordi assunti. In questa prospettiva, il contratto di società reca in sé il 'costante rischio struturale' che il controllo dell'impresa da parte degli impreditori possa essere esercitato in modi che confliggono com l'interesse dei proprietari: puó infatti accadere che gli organi dotati di poteri discrezionali, violando le regole e gli obbiettivi inizialmente stabiliti, pongano in essere comportamenti 'abusivi' che ledono gli interessi dei singoli soci e delle minoranze." 
Para solução dos impasses surgidos na vida societária, envolvendo tanto os interesses internos como os externos à companhia, e para que se possa aplicar a decisão mais justa para o caso, é fundamental que o juiz tenha acesso à situação completa, ao panorama geral, envolvendo a companhia e seus acionistas, o que implica necessariamente que seja levado ao seu conhecimento, não apenas o problema específico e imediato que envolve as partes, mas também, e principalmente, a situação geral da companhia e o cenário que envolve os acionistas, a constituição da sociedade e as condições de sua existência.

O que se verifica na análise dos casos levados à apreciação do Judiciário, é que, na maior parte das vezes, o conflito surgido e levado a conhecimento do juiz é apenas uma face da situação real, que é muito mais complexa do que as partes expõem no processo.

Desta forma, quando um acionista minoritário impugna determinada decisão tomada em Assembléia ou ato praticado por um administrador, com base na inobservância de algum dispositivo legal ou estatutário, uma análise retrospectiva dos fatos ocorridos envolvendo o acionista e a sociedade e seus controladores, pode demonstrar que o conflito real não é apenas a determinação da validade ou não da decisão impugnada, o que existe, na grande maioria dos casos, é uma situação mais ampla, envolvendo conflitos de interesses entre os sócios, controladores e minoritários, que, por não terem sido solucionados, levaram ao ajuizamento da ação.

A solução do conflito real existente, envolvendo os acionistas e a sociedade, requer não apenas a solução dessa situação imediata, que não se apresenta isolada $^{94}$, mas depende da compreensão do contexto que envolve a companhia e seus

${ }^{94}$ GAMBA, Cinzia, Dirito Societário...., pág. 176, assim expõe sua opinião: "La conseguenza di questo stato di cose (a ocultação, para o juiz, da situação real envolvendo os conflitos societários) - ha rilevato Enriques - è che al giudice viene sottoposta soltanto uma porzione dei fatti che hanno originato la lite, ovvero i fatti vengono presentati nelllo spetro di uma fattispecie giuridica che permette ai soci dissenzienti di avvalersi dello strumento di tutela giurisdizionale prescelto: com il che si profila il pericolo concreto che il giudice, rimanendo vincolato al núcleo delle prospettazioni offerto dalle parti, non colga l'essenza del contrasto insorto tra i soci e si arresti ad uma soluzione 'rispettosa soltanto del dato formale della legge"”. 
acionistas, sob pena de a solução oferecida não possibilitar a composição completa dos interesses em conflito e o retorno da companhia à normalidade.

No entanto, se não for trazido ao conhecimento do juiz a situação completa que envolve as partes e a companhia, a decisão proferida solucionará apenas o problema imediato, mas certamente não será eficaz para a solução do conflito maior, o que poderá levar ao ajuizamento de outras ações, permanecendo o conflito inicial.

No sistema jurídico brasileiro, devem as partes fornecer ao juiz todos os elementos necessários para que ele tome conhecimento da situação fática e considere, em sua análise, não apenas a controvérsia imediata trazida aos autos, mas também todos os demais elementos e fatos que podem influenciar sua decisão informando todos os conflitos que levaram ao ajuizamento da ação.

Já no sistema da Common Law, os juizes têm maior liberdade para apreciar e considerar outros elementos além dos inicialmente trazidos aos autos pelo Autor e pelo Réu e, somente com a apresentação do quadro completo, formará sua convicção, que sob este aspecto, tende a ser mais eficaz do que as decisões proferidas no sistema romano-germânico ${ }^{95}$.

\footnotetext{
${ }^{95}$ GAMBA, Cinzia. Diritto Societario..., pág. 201, compara as formas de atuação do Tribunal de Milão e da Corte de Delaware, que são, segundo a autora e diversos estudos por ela citados relacionados à análise do sistema jurídico norte-americano e italiano (inclusive os citados neste trabalho elaborados por ENRIQUES, Luca), os tribunais mais atuantes na solução de conflitos empresariais nos Estados Unidos e na Itália, no que se refere à atuação do juiz para determinação dos fatos que serão levados a seu conhecimento e que determina a eficácia das decisões tomadas para solução definitiva dos conflitos envolvendo as sociedades por ações: "Al modello di determinazione dei fatti riscontrabile nei provvedimenti del Tribunale di Milano, nei quali spesso rimangono in ombra il 'conflito reale' e le effettive ragioni di contrapposizione del caso delle decisioni rese in materia societaria dalle Corti dello Stato americano del Delaware. Si è rilevato che nelle pronunce dei giudici americani la narrazione dei fatti della controvérsia societária prende le mosse dalla constituzione della società, fornisce l'indicazione dell'identità dei soci fondatori, dei rapporti che intercorrono tra i soci e tra i soci e la società (rapporti di parentela, rapporti di impiego, etc.), dà una descrizione particolarreggiata degli antefatti in cui si inquadra la controvérsia, dai quali spesso scaturiscono le ragioni reali della lite, e, infini, ricomprende i fatti specifici posti a fondamento della controversia, i quali vengono riletti alla luce del loro inquadramento nel più ampio contesto considerato. Contrariamente a quanto è dato riscontrare nelle pronunce italiane, dunque, le opinions delle Corti del Delaware si basano su di una individuazione dei fatti idonea a fornire al giudice un inquadramento tendenzialmente completo della complessità del conflitto reale, individuato alla luce del contesto contrattuale in cui si è originata e definita la lite, e tenendo altresi conto dello specifico ambiente economico-impeditoriale in cui opera la società coinvolta o teatro della lite."
} 
É essencial que os juízes tenham acesso a todas essas informações, que serão necessárias para que possam formar sua convicção e determinar o papel de cada parte, as relações de interesses, os atos praticados e os comportamentos de cada um, que levaram à ocorrência da situação que atinge a empresa e que motivou o ajuizamento da ação.

Cinzia Gamba ${ }^{96}$ conclui, neste contexto, que é necessário que o juiz fundamente sua decisão sobre uma investigação dos fatos que seja o mais próxima possível da realidade da situação concreta que tenha dado origem à controvérsia. Para isso, ele deve compreender as possíveis motivações, tanto legítimas quanto ilegítimas das pessoas envolvidas na vida societária ${ }^{97}$. Essa ponderação ganha maior relevo quando se trata dos votos proferidos em conflito de interesses. Muitas vezes, a caracterização do conflito não é fácil e objetiva, requer a análise da situação de fundo envolvendo o acionista, a empresa e os demais sócios para que o juiz forme sua convicção.

Desta forma, a decisão proferida terá maior eficácia quanto mais próxima estiver de solucionar os problemas envolvendo a companhia, pondo fim às controvérsias envolvendo as partes afetadas e evitando assim o ajuizamento de outras ações e continuidade dos conflitos.

Por outro lado, como pondera Cinzia $\mathrm{Gamba}^{98}$, a aplicação meramente formal e passiva da lei, sem que o juiz tenha a preocupação de verificar e procurar solucionar o conflito real, pode legitimar a lesão sofrida pelo minoritário e agravar a situação envolvendo a empresa o que pode estimula o comportamento oportunístico e abusivo daqueles que agiram com intenção de prejudicar a sociedade ou os minoritários.

${ }^{96}$ Diritto Societario..., pág. 177.

${ }^{97}$ Diritto Societario..., pág. 177.

${ }^{98}$ Diritto Societario..., pág. 71: "Per converso, l'applicazione formale e passivo del dato normativo, non accompagnata da um approccio sostanzialistico - sostenuto da un'analisis che investa i risvolti e le implicazioni economico-finanziarie dei fatti che hanno originato la controvérsia - al caso di specie, può condurre alla pronuncia di sentenze che, fermandosi all'apparenza e non penetrando la sostanza dei rapporti coinvolti, di fatto, 'legittimano' lesioni delle posizioni soggettive dei soci 'di minoranza'." 
Nas companhias fechadas, familiares em sua maioria, os interesses dos sócios ganham maior relevância na determinação das relações e do papel de cada um na sociedade, e qualquer decisão tomada quanto à administração da companhia deverá considerar essa característica e os parâmetros que os sócios ajustaram entre si ao contratar a sociedade.

Nessas sociedades, é comum que um problema pessoal ou familiar afete a vida da sociedade e as disputas entre os familiares reflitam nas decisões tomadas em Assembléia Geral.

Para evitar essa situação, além do conhecimento dos fatos envolvendo a controvérsia trazida a conhecimento do juiz, é importante também que ele tenha conhecimento das operações e consequiências econômicas relacionadas a essa controvérsia, para que a situação seja não apenas juridicamente, mas economicamente eficaz $^{99}$.

A necessidade oferecer soluções para as situações ocorridas durante a vida da sociedade, em razão da impossibilidade de o contrato social prever todas essas situações, deve, portanto, ser analisada sob a perspectiva dos princípios gerais que regem as sociedades por ações e das características da Lei, que estabelece padrões e conceitos abertos, a serem supridos pelo intérprete.

\footnotetext{
${ }^{99}$ GAMBA, Cinzia. Diritto Societário..., pág. 71.
} 


\section{III - OS DIVERSOS INTERESSES ENVOLVIDOS NA ADMINISTRAÇÃO DAS S.A.}

Interesse é a relação que existe entre uma pessoa que, ao avaliar uma situação, exprime um julgamento de valor com relação à situação em si e aos bens nela envolvidos. Para que exista interesse, é necessário que seja atribuído, por aquela pessoa, importância, valor, utilidade ou relevância, para a situação apresentada a ela, ainda que esse interesse seja apenas íntimo e pessoal e não reflita ou afete outros interesses ou tenha relevância para o Direito. Por outro lado, o interesse de uma pessoa pode ser, perante o Direito, juridicamente relevante e, portanto, merecer proteção jurídica.

Rodrigo Ferraz Pimenta da Cunha ${ }^{100}$ faz a seguinte distinção ao tratar dos diversos tipos de interesses que um indivíduo pode ter: "A doutrina, em distinção clássica, alude a interesse subjetivo e objetivo. No primeiro caso, a conceituação parte de uma avaliação pessoal, interna, tendo o vocábulo, sobretudo, o sentido de juízo de valor. No segundo, o interesse possui caráter externo e se encontra intimamente ligado à idéia de necessidade, exprimindo uma aspiração da pessoa, física ou jurídica, aos bens capazes de satisfazer suas exigências individuais.”

O conceito de Jhering de direito subjetivo como o interesse juridicamente protegido é o mais adotado pela doutrina para fins de definição, ainda que com críticas ${ }^{101}$.

${ }^{100}$ Estrutura de Interesses nas Sociedades Anônimas. São Paulo: Quartier Latin, 2007, pág. 33.

${ }^{101}$ FERRAZ JR., Tercio Sampaio. Introdução..., pág. 142: "Uma outra concepção nos traz von Ihering (1864: 60): a teoria do interesse. O convívio humano revela conflitos de interesses. Alguns destes tornam-se juridicamente protegidos pelo ordenamento. A teoria cobre os casos em que as outras tinham dificuldade: loucos, crianças e nascituros têm interesses que antecedem ao próprio ordenamento, o qual, para permitir a convivência da liberdade de um com a de outro, os harmoniza. Em regra o interesse, por exemplo, do credor em receber seu crédito, está protegido em face da obrigação do devedor de pagar. A concepção, no entanto, é demasiado privatista, isto é, vê o problema apenas do ângulo do direito privado em que rege o princípio da autonomia da vontade. Como fica, por exemplo, a situação do Direito Penal, em que o Estado pune o comportamento do delinqüiente? Se atribuirmos à comunidade como um todo um interesse que é protegido em face do ato delituoso, a palavra interesse tem aqui um outro sentido, posto que não se trata de proteger um interesse (o da comunidade) contra outro interesse (o do delinqüiente), 
A partir desse conceito, pode-se concluir pela existência de dois tipos de interesse, os que são relevantes para fins jurídicos e, portanto, geram direitos que são regulados e protegidos pela lei e aqueles que não geram efeitos jurídicos por não envolverem uma situação tida como juridicamente relevante.

Quando determinadas pessoas unem seus interesses pessoais e parte de seu patrimônio, em busca de um objetivo comum a ser atingido através de um ente autônomo que realizará uma ou mais atividades pré-determinadas, que têm o potencial de atribuir, a essas pessoas, resultados financeiros, com a remuneração do patrimônio e dos conhecimentos pessoais por elas investidos na realização dessas atividades, verifica-se a constituição de uma sociedade.

Os sócios fundadores de uma sociedade têm, todos eles, um interesse comum que é a criação desse ente, que será dotado de personalidade jurídica própria e, em consequiência, terá um patrimônio autônomo, se cumpridos todos os requisitos estabelecidos em lei. Em razão da coincidência desse interesse fundamental, é possível constituir a sociedade, como afirmou Tullio Ascarelli ${ }^{102}$ : “Que acontece, pois, na sociedade? Por um lado, parece-me inegável que, na constituição da sociedade, as várias partes têm interesses antagônicos, exatamente como nos contratos de escambo; por exemplo, no que respeita à avaliação das respectivas contribuições; à determinação da respectiva ingerência na administração; à distribuição dos lucros e das perdas. Cada sócio visa a tirar da própria contribuição o máximo lucro, pondo-se, destarte, em conflito com os demais. No contrato de sociedade o direito é tão consciente desse contraste que intervém (com as normas sobre a sociedade leonina) para limitar equitativamente as possíveis desproporções entre os sócios. De outro lado, no entanto, a constituição de uma sociedade representa apenas um primeiro passo: a sociedade, uma

como é o caso do credor e do devedor. A dogmática não confere nem pode conferir ao 'interesse' do criminoso nenhuma qualidade jurídica; falar de um 'interesse' ao crime, que se contrapõe ao interesse da comunidade é torcer o sentido das palavras. Ademais, mesmo o interesse da comunidade, ainda que protegido, não dá margem para se falar em direito subjetivo no mesmo sentido que se fala em direito subjetivo do credor, salvo em termos de uma imprecisa metáfora. Além disso, a expressão direito subjetivo deve cobrir situações, como a dos direitos políticos, que não se enquadra também na concepção privatista de von Jhering: o direito de votar e ser eleito não contrapõe interesses, pois embora se pudesse dizer que o eleitor tem o direito de ver seu voto recebido e acatado pelos órgãos do Estado, é de se convir que não é essa sua função principal." (Grifos no original).

102 O Contrato Plurilateral, em Problemas..., pág. 376. 
vez constituída, visa a uma finalidade comum a todos os sócios, todos interessados na melhor realização dela; constitui um instrumento que, uma vez constituído, favorece a todos os sócios.”

Desta forma, no momento da realização da Assembléia Geral ou assinatura da escritura pública de constituição, os interesses e objetivos particulares dos sócios estão atendidos e harmonizados para permitir a consecução do interesse comum de todos e a constituição da sociedade, através da qual se obterão os resultados dos esforços e investimentos por eles realizados.

Porém, nem todos os interesses dos sócios fundadores coincidem no momento imediatamente anterior ao de sua constituição. Um ou mais dos sócios, podem pretender atuar no dia-a-dia da sociedade, acompanhar o andamento de suas atividades, representá-la ou determinar seus rumos gerais enquanto outros podem apenas procurar retorno financeiro de seus investimentos. Podem também alguns sócios pretender ocupar cargos da administração e, através da sociedade, exercer sua atividade profissional, recebendo com isso remuneração suficiente para seu sustento, independentemente dos dividendos a serem distribuídos aos demais sócios.

Nesse cenário, é muito comum deparar-se com situações em que vários dos interesses dos sócios fundadores são opostos e a grande dificuldade de constituição de uma nova sociedade consiste justamente na harmonização e regramento desses interesses, permitindo a constituição desse novo ente e evitando que esses interesses opostos surjam durante a vida da sociedade e dificultem ou impeçam sua continuidade.

Quando tratamos da constituição de uma sociedade, com personalidade jurídica própria, patrimônio separado e que tem por escopo realizar as atividades constantes no Estatuto Social para, através delas, garantir sua continuidade e a apuração de resultados econômicos para os investimentos realizados por seus sócios, poderíamos imaginar que os interesses dos sócios permaneceriam, durante toda a existência da sociedade, alinhados e voltados para que esse objetivo fosse alcançado. 
O que se verifica, no entanto, é que no momento seguinte à constituição da sociedade, os interesses dos sócios podem se tornar antagônicos entre si e, por vezes, contrários até mesmo aos da sociedade o que pode dificultar sua própria existência.

$\mathrm{Na}$ medida em que o Direito busca regrar os interesses relevantes para a vida em sociedade e estabelecer procedimentos e conseqüências para os conflitos que possam surgir da convivência dentro de um sistema de normas que permita a vida em comunidade, não poderia passar despercebida a existência de conflitos entre os interesses envolvidos na vida societária, considerando inclusive a importância da existência das pessoas jurídicas para a economia capitalista e até mesmo para o equilíbrio de forças econômicas mundial. Por esse motivo, existe a necessidade de se criarem institutos e regras que previnam e solucionem tais conflitos. Em setores estratégicos para a economia de uma país, o Estado pode ter interesse em favorecer o aporte de recursos para garantir a realização de sua função social, ou ainda, adquirir participação societária que permita participar das decisões assembleares e garantir que os interesses internos dos sócios não afetem sua existência.

O reconhecimento da relevância do papel das companhias para o desenvolvimento de economias e mercados, ao mesmo tempo que é benéfica para os países fez surgir problemas que antes não eram tidos como relevantes, em razão do grande individualismo que permeou a legislação e doutrina dos séculos XIX e XX que serviu para estimular a indústria e o comércio. Atualmente, o impacto social, econômico e ambiental que as atividades empresariais causam aumentou a preocupação de que os empresários, na condução de seus negócios, se responsabilizem em observar esses interesses externos e utilizem a estrutura societária, não apenas para obtenção de lucros, mas também em cumprimento à "função social" relacionada à propriedade dos meios de produção e que serve de limite ao exercício do poder de controle do acionista controlador e, portanto, da sociedade.

A importância da manutenção da existência de sociedades estratégicas para a economia de uma país e da proteção a esses interesses externos fica ainda mais evidente em momentos de crise econômica e financeira como a que atingiu os mercados internacionais em setembro de 2008. A necessidade de intervenção estatal 
para garantir o funcionamento de sociedades consideradas essenciais para o equilíbrio dos mercados financeiros levou os governos de diversos países, principalmente norteamericano, inglês e até mesmo brasileiro, a criar linhas de crédito e injetar recursos para tentar evitar o aprofundamento um cenário de recessão que se apresenta nesses países.

Várias críticas foram feitas às formas as aplicações desses recursos foram estruturadas mas é praticamente unânime a concordância quanto à necessidade de intervenção estatal para se evitar o aumento da crise e que as perdas sofridas pelas empresas, por má gestão ou em decorrência da própria crise, levam a uma crise semelhante à Grande Depressão que atingiu principalmente os Estados Unidos na década de 1930 que levou milhares de empresas e bancos à falência e causou aumento brutal nas taxas de desemprego. 


\section{III.1. - INTERESSES INTERNOS}

Um acionista, ao ingressar em uma sociedade por ações, possui interesses próprios e tem em vista as vantagens que obterá com a participação na companhia, através do recebimento de dividendos ou em sua atuação direta como administrador da companhia. Para isso, na negociação dos termos do Estatuto Social, os acionistas buscam preservar esses interesses, para que o Estatuto reflita as condições iniciais nas quais os acionistas concordaram com a constituição da sociedade e a conferência de recursos e esforços na realização do objeto social.

A partir de sua constituição, os interesses pessoais dos acionistas ficam subordinados aos da companhia e os acionistas precisam cooperar entre si para que os objetivos da companhia sejam alcançados. Independentemente do percentual de participação do acionista no capital social e do poder decisório que essa participação lhe atribua, o acionista, durante toda a vida da sociedade, deverá agir de boa-fé e com lealdade para com os demais acionistas e procurar sempre alcançar os objetivos da sociedade e atender a seus interesses, que é fundamental existência e funcionamento da companhia.

A evolução da estrutura de organização dos poderes internos de administração das sociedades por ações, culminou com a consagração do princípio majoritário para tomada de decisões quanto aos rumos da atividade social e para alterações estatutárias. Como ponderou Waldemar Ferreira ${ }^{103}$ "A submissão da minoria à maioria é essencial no regime do anonimato e sem ela impossível seria o funcionamento das sociedades anônimas ou comanditárias por ações. Não poderiam elas celebrar negócios de nenhuma espécie se carecessem, para a segurança dos com que contratassem, do assentimento, sem discrepância, de todos os acionistas. A vontade

${ }^{103}$ O Direito Insurrecional..., pág. 8. 
social seria sempre plural, nunca única, como se inexistisse a personalidade jurídica societária, íntegra e una, como sujeito ativo e passivo de direitos e de obrigações."

O reconhecimento de que, para melhor funcionamento da companhia, os acionistas titulares da maioria do capital social devem deter os poderes para aprovar as deliberações sociais e que os demais acionistas vencidos ou ausentes das deliberações devem acatar as decisões regularmente tomadas e que tenham obedecido aos requisitos legais, levou à criação de mecanismos de proteção dos acionistas minoritários em face de atos praticados com abuso desse poder de direção, pela maioria e/ou pelos administradores.

Assim, para evitar a ocorrência de abuso do poder de controle da sociedade, em prejuízo dos acionistas minoritários ou para atribuição de vantagem ilícita ao controlador, foram desenvolvidos, pela doutrina e jurisprudência, mecanismos de controle do poder de controle. De outro lado, a lei também procurou especificar os direitos que cabem a todos os acionistas e que são irrenunciáveis e protegidos por lei e os direitos que cabem especialmente aos acionistas minoritários, enquanto permanecerem como tal, conferindo caráter essencial à proteção desses direitos, como forma de manter a estrutura de controle da companhia e os incentivos aos investimentos dos acionistas, na sociedade.

Para isso, é importante delimitar quais são os interesses e direitos dos acionistas, especialmente os minoritários, que, por definição, encontram-se afastados da esfera de poder decisório da companhia, e merecem proteção para evitar que sejam prejudicados pelos atos e decisões tomadas pelos controladores e administradores, quando tais decisões e atos sejam contrários não apenas aos deveres expressamente definidos por lei, mas também em face dos princípios gerais estabelecidos no nosso ordenamento para exercício dos poderes dos controladores e administradores. Esses direitos individuais, como analisou Tullio Ascarelli ${ }^{104}$, podem

${ }^{104}$ Em Vícios das Deliberações Assembleares. Direitos Individuais dos Acionsitas. Prescrição, em Problemas..., pág. 543: "Os direitos individuais dos acionistas, vimos, podem relacionar-se apenas aos limites dos poderes da maioria; ou podem relacionar-se aos limites dos poderes da sociedade. No primeiro caso pode o estatuto originário, que assenta no consentimento unânime dos subscritores, estabelecer, a seu respeito, uma disciplina diversa da legal ou até derroga-los, embora não o possa uma deliberação por maioria que altere os estatutos; no segundo caso, ao contrário, nem sequer o estatuto originário (e, a 
ser divididos em duas categorias, a primeira estabelece limites aos poderes da maioria e o Estatuto, aprovado pela unanimidade dos acionistas, pode estabelecer uma disciplina própria desse poder de controle, a segunda categoria de direitos estabelece limites aos poderes da sociedade em relação aos acionistas e, nesse caso, nem o Estatuto ou Assembléia dos sócios, ainda que por unanimidade, podem afastar ou alterar a disciplina legal.

Tullio Ascarelli prossegue ainda distinguindo três categorias de direitos individuais dos acionistas: (a) os direitos privilegiados que cabem a uma categoria de acionistas; (b) direitos direitos que cabem a cada acionista ou a cada acionista ordinário, que não podem ser afastados, ainda que por deliberação unânime; e (c) direitos que cabem a cada acionista ou cada acionista ordinário que podem ser afastados por deliberação unânime dos acionistas ${ }^{105}$.

Como pondera Cinzia Gamba ${ }^{106}$, se o controlador fosse livre para exercer o controle da companhia e pudesse reduzir os direitos dos minoritários em relação aos inicialmente contratados ou pudesse colocá-los em situação pior do que se eles não tivessem ingressado na sociedade, a participação de sócios numa companhia seria totalmente irracional.

O equilíbrio entre a proteção dos direitos dos acionistas e de seus investimentos na companhia, em face da necessidade de assegurar aos controladores e administradores liberdade para decidir quanto ao melhor rumo dos negócios e a forma de atuação da empresa, desde que estes tenham agido de acordo com as regras e princípios gerais do Direito Societário, ainda que as decisões por eles tomadas acarretem prejuízos à companhia é um dos problemas principais enfrentados pelo Direito Societário e pelos tribunais ${ }^{107}$.

fortiori, ao menos em princípio, a deliberação unânime da maioria), embora assentando no consentimento unânime, pode estabelecer uma disciplina diversa da legal."

${ }^{105}$ Vícios das Deliberações... em Problemas..., pág. 547.

${ }^{106}$ Diritto Societario...., pág. 42: "...di qui la necessità di garantire alcune esigenze minimali di tutela, in assenza delle quali non avrebbe ragione d'essere da parte dei soggetti interessati agli utili e al valore del suo patrimonio l'adesione al contratto di società."

107 ALLEN, William T. Modern Corporate Governance..., pág. 13: "Thus, the business judgment rule deals with one of the core problems of corporate governance: how can we offer to directors protection from liability for claims of insufficient attention (and thus encourage them to authorize risky transaction), while still offering sufficient incentives to assure investors that directors act in an engage, monitoring rule." 
O sistema jurídico de cada país estabelece mecanismos e regras que regulam a atividade empresarial e protegem os interesses dos acionistas minoritários contra atitudes oportunistas e abusivas, da parte dos administradores e acionistas controladores, com o objetivo de garantir que todos os acionistas sejam tratados de forma igualitária e não tenham benefícios particulares ${ }^{108}$.

Quando da apresentação de um caso concreto, para apreciação do Judiciário, envolvendo prejuízo a direitos e interesses de acionistas minoritários, deverá o juiz averiguar, mediante análise da situação fática envolvendo a empresa e o teor do Estatuto Social em vigor e do Acordo de Acionistas, caso existente, quais são os interesses que norteiam os acionistas e que são essenciais para a manutenção do equilíbrio de poderes e interesses internos que permitam à empresa realizar suas atividades, cumprindo sua função social.

Em se tratando de companhias fechadas, é provável que dessa análise fiquem evidentes outros interesses relevantes para os acionistas, que foram determinantes para sua participação na empresa, tais como, por exemplo, a ocupação de cargos na administração da empresa, a distribuição de determinada participação nos lucros da empresa, a atuação em certos mercados e a manutenção do controle na forma inicialmente determinada.

O que se verifica na prática é que quando esses interesses deixam de ser atendidos, o conflito se instala e a continuidade da companhia fica ameaçada, levando as partes ao Judiciário, a quem caberá a avaliação de cada um dos interesses envolvidos e a determinação quanto à ocorrência, ou não, de atos contrários aos interesses, não apenas dos sócios, mas também da sociedade, que contrariem os princípios gerais que estabelecem os limites para administração e controle da companhia.

\footnotetext{
${ }^{108}$ Neste sentido, CONAC, Pierre-Henri, ENRIQUES, Luca e GELTER, Martin. Constraining Dominant Shareholders'..., pág. 13, ao analisar os mecanismos constantes na legislação e utilizados pelos tribunais na Alemanha, Itália e França, constatam que "...whether implicity or explicity, the three countries grant shareholders a right to be treated equally by the corporation, which might prevent it from granting unjustified benefits to its dominant shareholders."
} 
Nos Estados Unidos, a constatação da ocorrência dessas situações e a necessidade de se aplicarem soluções adequadas, de acordo com as características da companhia, desenvolveu disciplina específica aplicável às sociedades por ações de capital fechado (close corporations) ${ }^{109}$, nas quais o fato de os acionistas minoritários não poderem alienar livremente suas ações no mercado, justificou a adoção de soluções específicas para se impedir o abuso do poder de controle pelo acionista controlador e os administradores.

O sistema jurídico norte-americano desenvolveu padrões de conduta aplicáveis aos administradores de companhias, independentemente de serem do tipo aberto ou fechado, denominados fiduciary duties. A definição e análise doutrinárias da extensão desses standards de conduta e a ocorrência de abuso por parte dos administradores e acionistas controladores, possuem conteúdo semelhante aos deveres dos acionistas controladores e administradores de sociedades por ações no Brasil.

No entanto, se a companhia em questão for uma close corporation, os juristas norte-americanos entendem que a extensão desses deveres abrange outros fatores relacionados às expectativas e interesses dos acionistas, principalmente os minoritários, desde que avaliados como expectativas e interesses "razoáveis" (reasonable expectations), e que os controladores e administradores devem atender a essas expectativas não podendo provocar situações excessivamente prejudiciais aos minoritários, que alterem substancialmente as regras e condições ajustadas quando de seu ingresso na companhia e que os levaram a realizar o

109 O'NEAL, F. Hodge e THOMPSON, Robert B. O'Neal's Close Corporations. $3^{\text {a }}$ Edição. Illinois: Callaghan \& Company, 1986 e 1989, Vols. 1 e 2., vol. 1, Capítulo 1, pág. 2: “The term 'close corporation' has been defined in various ways. It is often used to distinguish and set apart the corporation with only a few shareholders from the 'public issue' or publicly held corporation. Thus, a definition frequently encountered describes the close corporation simply as a corporation which has relatively few shareholders. (...) Participants in an enterprise with few shareholders usually know each other personally and are more likely to reach decisions by a 'genuine interchange and pooling of views'. (...) An economic approach, somewhat akin to the incorporated partnership notion, focuses on one of the most significant characteristics of many corporations with a small number of shareholders by defining the close corporation as one in which "management and ownership are substantially identical." MOLL, Douglas K. Shareholder Oppression \& Dividend Policy in the Close Corporation. Washington: Washington \& Lee Law Review, 2003. Disponível em: 〈http: //ssrn.com/abstract=437162>. Acesso em 20.out.2008, pág. 07: "A close corporation is a business organization typified by a small number of stockholders, the absence of a market for the corporation's stock, and substantial shareholder participation in the management of the corporation. (...) Moreover, close corporation investors are often linked by family or other personal relationships that result in a familiarity between the participants. (...) In a close corporation, the board is ordinarily controlled 'by the shareholder or shareholders holding a majority of the voting power'." 
investimento na empresa. A análise dessas situações levou à construção da teoria da Opressão dos Acionistas Minoritários (Oppression of the Minority Shareholder)

A ocorrência de violação a esses deveres e a existência de atos coordenados para opressão dos minoritários dependerá da verificação, no caso concreto, de ocorrência de abuso do poder de controle ou de realização de atos não condizentes com os deveres que os administradores e acionistas controladores que oprimam o minoritário, mantendo-o preso à companhia em situação prejudicial a seus interesses e patrimônio $^{110}$.

No Brasil, os acionistas controladores detém o poder para controlar as deliberações tomadas na Assembléia Geral, como órgão máximo de administração da companhia. Esse poder de controle não pode ser exercido, como discorremos acima, de forma totalmente livre. A liberdade do acionista controlador encontra seus limites nos interesses tanto da companhia quanto nos interesses externos à companhia, relacionados à sua função social.

Independentemente dos limites específicos estabelecidos por lei e pelo Estatuto Social, para o exercício do poder de controle, como princípio geral aplicável às relações contratuais, deve o controlador e o administrador agir de boa-fé e com lealdade para os demais acionistas.

O princípio da boa-fé nas relações negociais permeia todo o sistema jurídico do Direito Privado e possui um peso importante na constituição e condução dos negócios sociais, em razão do dever de colaboração e de união de esforços para realização do fim comum (que nas sociedades caracteriza a existência da affectio societatis).

\footnotetext{
${ }^{110}$ MOLL, Douglas K. Shareholder Oppression..., pág. 15, sintetiza os três aspectos considerados na avaliação da ocorrência de opressão de acionistas minoritários: "The development of a shareholder's cause of action for oppression requires courts to determine when 'oppressive' conduct has occurred. In wrestling with this issue, the courts have developed three principal approaches to defining oppression. First, some courts define oppression as 'burdensome, harsh and wrongful conduct... a visible departure from the standarts of fair dealing and a violation of fair play on which every shareholder who entrusts his money to a corporation is entitled to rely.' Second, some courts link oppression to breach of an enhanced fiduciary duty owed from one close corporation shareholder to another. Third, a number of courts tie oppression to the 'frustration of the reasonable expectations of the shareholders'."
} 
Além disso, o exercício dos poderes do controlador encontra limites na preservação dos demais interesses e direitos envolvidos na sociedade, que podem ser analisados sob dois aspectos: o primeiro, diz respeito ao interesse substancial do controlador de tomar as decisões que entenda pertinentes para a companhia; o segundo aspecto trata do interesse instrumental para o exercício do poder de controle, que deve obedecer a certas formalidades e que exige que o controlador considere, em suas decisões, os demais interesses, internos e externos, vinculados à sociedade, agindo de boa-fé e lealmente ${ }^{111}$.

O reconhecimento de que os interesses do acionista controlador podem, em determinadas situações, ser conflitantes com o da sociedade, e que as decisões por ele tomadas poderão ser contrárias ao interesse social, possibilita a impugnação das decisões por ele tomadas em conflito de interesses, assunto que será discutido no Capítulo IV.3 abaixo. Por este motivo, a maioria, seja ela ocasional ou não, que determina a aprovação de matérias relacionadas à companhia, pode não traduzir o interesse social com relação àquelas matérias.

Como ressaltaram Isaac Halperin e Julio C. Otaegui ${ }^{112}$, com base em Mengoni, uma maioria que decide em benefício próprio, em prejuízo da companhia, não é uma "verdadeira maioria, mas apenas um grupo que degradou a votação a uma prova de força, de que saiu vitoriosa". Nessa situação, o princípio majoritário não foi estabelecido por lei "como sanção da prevalência do interesse da maioria enquanto interesse mais forte", esse critério foi introduzido como forma de “organização dos sócios e por isso, como meio de proteção do interesse comum dos sócios."

${ }^{111}$ GAMBA, Cinzia. Diritto Societario..., págs. 98 e 99: “.... nell' ambito dei rapporti privati ciò che rileva nel concetto di funzione e che caratterizza la discrezionalità del potere è il fatto che esso sai esercitato dal suo titolare per um interesse non proprio dell'agente, o comunque non solo proprio, ma per un interesse oggettivo o di altri soggetti. (...) I limiti al potere discrezionale permettono di ricostruire il contenuto della posizione soggettiva che si contrappone al potere privato, nella quale convivono due aspetti strettamente correlati ma pur sempre distinti: l'interesse strumentale a che il potere stesso sai esercitato secondo certe modalità, ossia in base a principi di corretezza che impongano al soggetto titolare del potere di prendere doverosamente in considerazione l'interesse altrui."

${ }_{112}^{112}$ Sociedades Anônimas. 2a edição. Buenos Aires: Ediciones Depalma, 1998, pág. 224.

${ }^{113}$ No mesmo sentido, SIMIONATO, Frederico Augusto Monte Sociedades Anônimas \& Interesse Social. Curitiba: Juruá, 2004, pág. 126: "A colocação do interesse social como interesse do sócio que tem na comunhão de interesses objetivos a serem perseguidos, não permite que a empresa, vista como um interesse próprio, possa cumprir sua função. A decisão majoritária é método de decisão, e não forma de 
O surgimento de Grupos societários, de direito ou de fato, e a existência de relações entre várias empresas, que possuem acionistas e administradores comuns altera a perspectiva quanto à atuação dos controladores na condução dos negócios sociais. Nos Grupos de direito, que se constituem na forma dos arts. 265 e seguintes da Lei das S.A., através de Convenção de Grupo arquivada no órgão competente do Registro do Comércio, as sociedades mantém sua personalidade e patrimônio jurídico próprios, o que significa que, ainda que combinem recursos e esforços para realização dos respectivos objetos, atividades ou empreendimentos comuns (art. 265), possuem interesses individuais próprios mas subordinados aos interesses do Grupo. Os administradores e acionistas das sociedades do Grupo devem, portanto, zelar pela preservação desses interesses, especialmente no caso de existirem minoritários, mas como a constituição do Grupo pressupõe a união de forças das sociedades para realização de objetivos comuns, podem ocorrer situações em que o interesse de uma sociedade seja subordinado ao de outra sociedade do Grupo, para potencializar o resultado do Grupo como um todo.

$\mathrm{O}$ art. 237 da Lei 6.404 prevê que os administradores das sociedades filiadas devem observar a orientação geral estabelecida na Convenção e as instruções dos administradores do Grupo que não importem violação da Lei ou da Convenção do Grupo, sem prejuízo de suas atribuições, poderes e responsabilidades, de acordo com os respectivos estatutos ou contratos sociais. Esta disposição decorre do fato de que, quando uma companhia ingressa em um Grupo, através da aprovação, por seus acionistas dos termos da Convenção, a estrutura administrativa da sociedade é alterada, o que dá direito aos acionistas dissidentes de exercer direito de recesso da companhia. A alteração da estrutura administrativa da sociedade acarreta a subordinação dos administradores às regras da Convenção e às determinações dos administradores do Grupo e também afeta diretamente a apuração de resultados da companhia, que poderão ser distribuídos entre as sociedades do Grupo, nos termos previstos na Convenção (art. 276), desde que isso não signifique a transferência total dos resultados de uma companhia para outra, havendo acionistas minoritários ${ }^{114}$. Os minoritários das companhias prejudicadas pelos atos praticados contrariamente ao

encontrar o interesse social. Se a decisão é contrária ao interesse social da companhia, ela deve ser considerada nula, mesmo que isto provoque efeitos drásticos, e a surpresa da doutrina clássica."

${ }^{114}$ CARVALHOSA, Modesto. Comentários...., vol. 4, Tomo II, pág. 300. 
disposto na Convenção poderão ajuizar ação contra os administradores da companhia de que participem e a sociedade de comando do Grupo para reparação dos prejuízos resultantes dos atos praticados com infração ao disposto no art. 276 ( $\left(3^{\circ}\right.$ do art. 276).

Não havendo Convenção de Grupo formalizada, os administradores de empresas coligadas ou sob controle comum subordinam-se ao disposto no art. 245, na realização de operações entre empresas coligadas, controladoras ou controladas. Além dos deveres gerais de conduta, previstos nos arts. 153 e seguintes da Lei 6.404, deverão ainda zelar para que as operações entre as sociedades observem condições estritamente comutativas, ou com pagamento compensatório adequado, sob pena de responderem perante a companhia pelas perdas e danos resultantes dos atos praticados com infração ao disposto neste artigo.

Modesto Carvalhosa, comentando esse artigo com base na experiência norte-americana e nos ensinamentos de Robert Clark, comenta os critérios para aferição da legitimidade da conduta dos administradores e controladores nas operações realizadas entre coligadas, controladoras ou controladas os quais partem do conceito de equidade (fairness) do comportamento e das operações analisadas. Nessa análise, a doutrina norte-americana escolhe entre dois testes de avaliação da operação: (a) comparação do negócio realizado com outro, hipotético; ou (b) comparação do negócio com outros similares, realizados no mercado ${ }^{115}$.

Ainda para análise dessas situações, prossegue o autor ${ }^{116}$ : “Assim, na prática, a pergunta que se deve fazer é a seguinte: se a companhia não fosse

\footnotetext{
${ }^{115}$ Comentários..., vol. 4, Tomo II, pág. 32: "De acordo com o primeiro teste, a decisão do controlador ou do administrador será unfair se o resultado da operação para a companhia controlada, coligada ou controladora for menos vantajoso do que seria caso a decisão tivesse de ser tomada por uma pessoa independente, não envolvida em qualquer conflito de interesses. Trata-se, tal teste, da conhecida armslength bargain comparison. De acordo com o segundo teste, a operação seria considerada legítima ou ilegítima, tendo em vista a sua comparação com operações similares efetivas pela companhia com terceiros."

116 CARVAlhosA, Modesto. Comentários..., pág. 33: "Entra aí, fundamentalmente a conduta do administrador: um administrador neutro, ou seja, de sociedade não pertecente ao grupo não convencional, celebraria o contrato daquela maneira e naquele momento? Ou, ainda: as exigências de crédito ou a disponibilidade compatível de recursos também aconselhariam o neegócio daquela forma e naquele momento? Poderiam ser procurados outros compradores ou vendedores que oferecessem condições de preço, de pagamento ou de financiamento mais vantajosos? Finalmente: as responsabilidades contratuais, cláusula penal, prefixação de perdas e danos e demais cláusulas de salvaguarda de direitos e modalidades de execução foram convencionadas de maneira geralmente adotada em negócios com terceiros e, assim, de acordo com a prática dos negócios comerciais?"
} 
controladora, controlada ou coligada, o negócio em tela seria firmado no mesmo valor, prazo, forma, financiamento etc.? (...) Deve-se indagar se o momento, ou a época, em que foi firmado o contrato teria sido o mais propício. (...) Daí decorre outra pergunta, para verificação do grau de comutatividade: um terceiro faria a transação com o produto, no momento ou na época em que tal negócio foi celebrado entre as sociedades pertencentes ao grupo de fato?"

As regras de conduta impostas pela lei e pelos Estatutos Sociais aos acionistas controladores e administradores, servem como incentivo para que estes se comportem de forma ética e leal, mas não são as únicas que exercem influência sobre o comportamento desses indivíduos.

Existem também sanções sociais, que pressionam os administradores e acionistas a agir de boa-fé e realizar um bom trabalho na condução dos negócios sociais. Assim, uma reputação abalada ou a desconfiança de negligência por parte de um administrador causa, além das conseqüências legais, conseqüências no seu círculo profissional e social, dificultando sua recolocação no mercado de trabalho e obtenção de parceiros e investidores para novos negócios ${ }^{117}$.

É fundamental que o sistema existente seja eficaz, para que a pessoa para quem a norma é endereçada permaneça motivada ${ }^{118}$ a agir corretamente e em benefício da sociedade. Independentemente dos motivos, jurídicos, morais ou sociais, que levam o controlador ou administrador a manter-se leal à sociedade e seus

\footnotetext{
${ }^{117}$ A análise da influência que as sanções "extra-jurídicas" possuem com relação ao comportamento dos administradores e acionistas, na condução dos negócios sociais, vem atraindo a atenção daqueles que estudam as motivações e formas de aumento da eficácia das regras que determinam os padrões de comportamento dos administradores e acionistas, conforme anota STOUT, Lynn A. In Praise of Procedure: an Economic and Behavioral Defense of Smith v. Van Gorkom and the Business Judgment Rule. Los Angeles: University of California School of Law. Research Paper Series. Research Paper No. 01-21. <Disponível em http://papers.ssrn.com/abstract_id=290938>, acesso em 28.nov.2008, pág. 12: "One potential answer may be that corporate directors want to do a good job because they fear not legal sanctions but 'social sanctions' - loss of reputation, disapproving remarks, hostile glances, even social shunning. This possibility has attracted much attention from corporate scholars in recent years."

${ }^{118}$ GAMBA, Cinzia. Diritto Societário..., pág. 62, pondera que "Le regole trasmettono inoltre incentivi, influenzando il comportamento degli operatori economici. Pertanto, um sistema istituzionale incapace di tutelare i diritti e gli accordi contrattuali è economicamente inefficiente, in quanto i soggetti che in esso operano non sono incentivati ad impegnarsi in attività economiche; per contro, l'impegno nelle attività di mercado ed imprenditoriali è massimo se le regole di um ordinamento 'funzionano' in modo efficace, riducendo i costi di transazione ed aumentano gli incentivi per i soggetti che le devono applicare."
} 
acionistas, as sanções previstas pelo sistema devem cumprir sua função e ser aplicadas de forma eficiente.

Outro aspecto que deve ser considerado na análise e interpretação das situações envolvendo conflitos entre os interesses internos nas companhias é a boa-fé e a lealdade dos acionistas entre si, como princípios que regem não apenas o contrato de sociedade mas os negócios jurídicos em geral. A doutrina e jurisprudência estrangeiras, especialmente a norte-americana, tratam especificamente dos casos em que um acionista se comporta de forma desleal com os demais sócios ${ }^{119}$ como hipótese em que o acionista desleal pode ser pessoalmente responsabilizado, ainda que a companhia não tenha sofrido prejuízos.

Em reconhecimento à existência de interesses internos dos acionistas, especialmente os minoritários, que devem ser preservados em face de atos abusivos praticados pelos demais acionistas, Waldemar Ferreira ${ }^{120}$ reproduziu trecho de acórdão proferido pelo Tribunal do Comércio de Siena, em 03.04.1911, em que se concluiu: "Quaisquer que sejam as circunstâncias (...), não deve a sociedade anônima, e não pode, converter-se em coisa particular de algumas pessoas, que acabariam por usar dela segundo sua própria vontade e como se de bens deles se tratasse: ela precisa subsistir no patrimônio do conjunto dos acionistas, patrimônio que deve ser gerido com as perspectivas da propriedade geral, não sendo permitido aos administradores substituir

119 RAMSEYER, J. Mark. Not-so-ordinary Judges in Ordinary Courts: Teaching Jordan v. Duff \& Phelps. Cambridge: Harvard Law School. John M. Olin Center for Law, Economics and Business, 08/2006. Disponível em: http://ssrn.com/abstract_id=927862, acesso em 01.dez.2008, pág. 5 ao analisar o caso Wilkes v. Springside Nursing Home, julgado pela Suprema Corte de Massachusetts, no qual se discutiu a suposta violação de deveres de lealdade, entre sócios detentores de $75 \%$ do capital social e o sócio minoritário, ao destituírem o sócio minoritário do cargo por ele ocupado na empresa, que era uma companhia de capital fechado, ressaltou que a escolha dessa forma societária foi o fator determinante para o resultado do julgamento desse caso: "Shareholders traditionally hold no fiduciary duties toward each other, it explained, but partners do. Yet close corporations are much like partnerships. As a result, shareholders in close corporations should hold duties similar to those of partners. Granted, the four

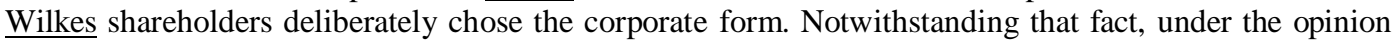
they incurred fiduciary duties close to those they would have owed had they chosen a partnership instead. In effect, the Wilkes court faced investors who could have selected strict fiduciary duties but opted for laxer duties instead, and then imposed on them rigid an demanding duties anyway. It faced investors who deliberately tried to waive fiduciary duties, in other words, and refused to let them. This is not just Massachussets. Both the Indiana and Illinois courts have explicitly adopted the Wilkes formula as well." (Grifos no original). CONAC, Pierre-Henri, ENRIQUES, Luca e GELTER, Martin. Constraining Dominant Shareholders'..., pág. 13, apontam que os tribunais alemães também reconhecem que os acionistas possuem dever de lealdade uns com os outros e podem ser responsabilizados se agirem deslealmente com os demais acionistas.

${ }^{120}$ O Direito Insurrecional..., pág. 11. 
por sua política pessoal a do anonimato que necessita constituir a base da sociedade. As resoluções propostas ao voto da assembléia hão de ser concordes com o espírito do pacto social e preceder de noção de utilidade para a sociedade."

Não poderia, por outro lado, o ordenamento reconhecer a relevância dos direitos internos dos acionistas, sem lhes conferir instrumentos que confiram eficácia a esses direitos.

Para isso, a Lei das S.A., considerando que a proteção dos interesses próprios dos acionistas se dá através da proteção dos interesses da companhia, prevê, no artigo 246, que a sociedade controladora deverá reparar os danos que causar à companhia por atos praticados com infração ao disposto nos artigos 116 e $117^{121}$, podendo a ação para reparação dos danos ser ajuizada por acionistas representantes de $5 \%$ (cinco por cento) ou mais do capital social; ou por qualquer acionista, desde que preste caução pelas custas e honorários de advogado devidos no caso da ação ser julgada improcedente.

Trajano de Miranda Valverde pondera que o objetivo da ação ajuizada em face do controlador que causou prejuízos à companhia é "restabelecer o equilíbrio e a hamornia dentro da organização."122 Assim, prossegue o autor, “...a sociedade é quem colhe, diretamente, os benefícios da ação, as indenizações porventura devidas pelos prejuízos sofridos por atos ilícitos, violadores da lei ou dos estatutos, praticados por seus órgãos de direção ou de fiscalização. Nas ações individuais, ainda

${ }^{121}$ A Ministra Nancy Andrighi, no Voto-Vista (vencido) proferido nos autos do REspecial $\mathrm{n}^{\circ}$ 633.338DF, julgado em 05.09.2006, DJ 04.12.2006, entende “...que, não obstante o art. 246 faça referência aos arts. 116 e 117, ele não esgota as hipóteses em que esses dispositivos têm aplicação. As demandas da sociedade, representada pelos minoritários (como bem observado pelo i. Relator), exercem-se da forma disposta no art. 246. As demais pretensões que nascem do descumprimento dos princípios estabelecidos nos arts. 116 e 117, a serem propostas por terceiros prejudicados, não se regulam por essa norma." "Na hipótese dos autos, claramente não estamos diante de uma das hipóteses contempladas no art. 246 da Lei das S.A. Os recorridos exerceram seu direito de retirada e, portanto, não são mais sócios da companhia. Assim, eles naturalmente não têm legitimidade para, com base no art. 246, pleitear, em nome da sociedade, o ressarcimento dos prejuízos causados pelo controlador. São, portanto, terceiros que, na qualidade de credores da companhia, foram prejudicados por atos praticados por ele, com abuso de poder."

${ }^{122}$ Sociedades por Ações. $3^{\text {a }}$ Edição. Rio de Janeiro: Editora Forense, 1959, vol. 3, pág. 328. 
quando o seu resultado aproveite ou prejudique à coletividade dos membros da sociedade, propondo-a, não tem o acionista senão em vista o seu próprio interesse."123

${ }^{123}$ No mesmo sentido, FERREIRA, Waldemar. O Direito Insurrecional..., pág. 52: “Ao acionista delegou-se essa importante missão, pelo direito de oposição às deliberações das assembléias gerais. Promovendo a anulação das deliberações irregulares ou ilegais, o acionista, ao mesmo tempo que salvaguarda os seus interesses individuais, protege a própria sociedade, para que se lhe não deturpe a finalidade, se lhe não desvirtuem os objetivos, assegurando-lhe existência regular e profícua." 


\section{III.2. - INTERESSES EXTERNOS}

Não há dúvidas hoje em dia do impacto que o funcionamento ou o encerramento de uma sociedade, principalmente de grande porte, como as grandes corporações dos dias de hoje, exercem sobre a comunidade local, para a geração de impostos e na economia regional, nacional e até mesmo mundial.

A apuração de resultados positivos ou negativos por uma sociedade pode gerar impactos de diferentes graus dependendo do tamanho e do volume de seus negócios, que afetam diretamente seus trabalhadores, consumidores, fornecedores e também o Estado, afetado pela arrecadação ou sonegação de impostos.

Considerando esta realidade, o art. 116 da Lei das S.A. estabeleceu, ao acionista controlador, limites ao exercício do poder de controle, o qual deve ter por objetivo "...fazer a companhia realizar o seu objeto e cumprir sua função social", mas encontra limites nas "...responsabilidades para com os demais acionistas da empresa, os que nela trabalham e para com a comunidade em que atua, cujos direitos e interesses deve lealmente respeitar e atender."

No que se refere aos demais acionistas da companhia, o legislador se preocupou em especificar os direitos, que o acionista controlador deve respeitar no exercício do poder de controle e que, nem mesmo o Estatuto Social poderá afastar (art. 109 da LSA) e estabeleceu os meiso através dos quais poderá responsabilizar o controlador pelos prejuízos causados (arts. 246, 28 e 287 da Lei $6.404)$.

O mesmo não ocorreu com os interesses externos à sociedade, os quais estão previstos de forma genérica neste artigo, cabendo à doutrina e à jurisprudência especificar e delimitar não apenas quais seriam esses interesses tutelados, 
mas também as pessoas legitimadas a exigir sua observância e as consequiências da interferência ou desrespeito a esses direitos e interesses.

Dentre os interesses externos diretamente vinculados aos da companhia e que, portanto, merecem proteção e devem ser observados pelo acionista controlador se compreendem, os trabalhadores da própria companhia, os quais poderão, inclusive, nos termos do parágrafo único do artigo 140, eleger um membro do Conselho de Administração, caso assim o preveja o Estatuto Social, os consumidores dos produtos e serviços por ela fornecidos, os credores, outras sociedades que sejam afetadas por suas atividades, empresas concorrentes, o meio ambiente, dentre outros.

Além desses interesses externos relacionados à companhia, outros poderão surgir e merecerão proteção, no caso concreto, servindo como limites à atuação da companhia e seus controladores e administradores, tais como, exemplificativamente, a proteção ao meio-ambiente, interesses sociais ou econômicos locais ou regionais da comunidade em que atua a companhia.

A valoração da relevância desses interesses externos, deve ser feita, em um primeiro momento, pelo acionista controlador, nos termos do artigo 116, em razão da necessidade de observar a função social da companhia na determinação de seus rumos.

Podem ocorrer situações em que a importância à proteção desses interesses externos à companhia, quando representem interesses importantes para a economia e a sociedade, justifiquem que o Estado, em casos excepcionais, intervenha, através de disponibilização de crédito ou aquisição de participação societária, naquela sociedade, para garantir que esses interesses sejam atendidos.

Por este motivo, e com base no disposto no inciso XXXV do artigo $5^{\circ}$, inciso II do artigo 170 da Constituição Federal e no artigo 116 da Lei das S.A., o Poder Judiciário poderá determinar medidas que afetarão a administração da sociedade, desde que comprovado o abuso por parte dos acionistas na condução dos 
negócios sociais que justifiquem essa intervenção e a necessidade de preservação de bens maiores $^{124}$.

Esses dispositivos não autorizam a interferência nas atividades de uma empresa, para que esta passe a atender a um interesse público com a superação dos demais interesses internos e da companhia, que também são relevantes para o direito e merecem proteção no sistema econômico capitalista brasileiro. A realização, pelo empresário, das atividades previstas no Estatuto Social da companhia, respeitando os interesses internos dos demais sócios e externos à sociedade, agindo de boa-fé e com lealdade, é garantida na Constituição Federal e é um dos fundamentos do capitalismo e que incentivam a iniciativa privada, impulsionando a economia. Frederico Augusto Monte Simionato $^{125}$ propõe que a fiscalização do Estado, sobre a a administração das sociedades, para verificação da observância de sua função social e o respeito aos interesses externos vinculados às suas atividades, deve se dar sob a perspectiva ética, considerando o todo da atuação empresarial, em razão da influência que as grandes empresas possuem sobre o coletividade e a economia, que reflete seu caráter institucional.

Deve-se buscar um equilíbrio para que esses interesses coexistam $^{126}$ e o julgador deverá, na avaliação dos elementos apresentados, levar em consideração todos os interesses envolvidos, sob pena de, ao ignorar algum deles,

\footnotetext{
${ }^{124}$ Como, por exemplo, no caso da empresa exercer atividade poluidora. O Estado pode intervir através da aplicação de multas, mas o Ministério Público também poderá ajuizar ação para que a companhia deixe de realizar aquela atividade ou utilizem meios menos poluentes, ainda que a utilização desses procedimentos acarrete prejuízos à companhia.

${ }^{125}$ Sociedades Anônimas..., pág. 23: "Não resta dúvida de que a empresa consagra o surgimento de um novo ente, que pode ser traduzido na sua perpetuação institucional, no aumento de produtividade e na redução de custos. Os administradores das sociedades por ações atuam sob o comando dos controladores, quase sempre despreocupados com o todo social. Mesmo que as legislações de países como França, Alemanha e dos EUA estabeleçam meios para o exercício do controle social sob a conduta dos administradores, a principal forma de controle deve ser realizada sobre o todo da atuação empresarial, impondo revisão do fenômeno administrativo e da própria empresa . É de adiantar que esse controle é uma resultante clássica do próprio sistema e possui no elemento ético sua maior transcendência valorativa, constituindo nova perspectiva para o trato das questões societárias da empresa, quer sejam internas ou externas.

${ }^{126}$ MUNHOZ, Eduardo Secchi. Empresa Contemporânea..., pág. 36: "A observação de que determinado interesse ligado à atividade empresarial (no caso, a livre concorrência) é alvo de preocupação central de outro ramo do direito (o concorrencial) põe em destaque a definição dos limites que o direito societário deve observar na abordagem dos chamados interesses extra-societários. Em outros termos, se parece unânime a idéia de que o direito societário deve preocupar-se com a consecução dos valores fundamentais da ordem econômica, expressos na Constituição, cumpre verificar de que forma poderá exercer melhor essa função, estabelecendo um equilíbrio adequado entre os interesses intra e extra-societários."
} 
permitir que a proteção de interesses externos prejudique o empresário que está atuando de forma legítima e merece proteção de seu investimento ou, caso contrário, autorizar a continuidade de uma prática da companhia que afeta, por vezes de forma irremediável, a comunidade, seus trabalhadores, o mercado de capitais e o meio ambiente.

Os credores da companhia são os mais diretamente afetados pelas alterações em seu patrimônio e portanto, possuem interesse em acompanhar a condução de suas atividades e resultados financeiros. Eventuais decisões que se revelem prejudiciais à companhia refletirão em seus resultados e na avaliação de seu crédito, influenciando diretamente a cotação dos valores negociados no mercado de capitais. Por esse motivo, a decisão de um credor, em reduzir o crédito de uma companhia ou requerer mais garantias, quando aparecem sinais de problemas em sua administração ou no equilíbrio financeiro, influenciará a decisão de outros credores, podendo, até mesmo, produzir uma seqüência de eventos que prejudicará a credibilidade da empresa no mercado.

Para proteção de seus créditos, os credores devem estar atentos às informações que circulam no mercado e acompanhar as decisões tomadas pelos acionistas e administradores de seus devedores, verificando o andamento dos negócios da companhia e a existência de problemas internos ou desvios na condução de suas atividades que possam influenciar a avaliação da empresa devedora e alterar as condições de seu relacionamento, se prevenindo de prejuízos em casos de devedores em dificuldades financeiras ou em situação pré-falimentar.

Grandes credores e as instituições financeiras possuem poder de barganha para obter garantias fortes, muitas vezes em valor superior ao de seu crédito e que, muitas vezes, envolvem a fiscalização direta da administração da companhia, através de um representante, restrições para distribuição de dividendos por determinado período ou montante e obtenção de garantias reais e/ou pessoais dos acionistas. Pequenos credores, por outro lado, não possuem poder de negociação e acabam mais expostos ao risco do devedor.

Nesse cenário, assume maior importância, para proteção dos credores, a atuação das instituições que auxiliam no controle e monitoramento da 
situação financeira e patrimonial das companhias, especialmente as empresas de auditoria e de avaliação de risco e de informações ao comércio, como, por exemplo, no Brasil, o SERASA, SEGAM, as Associações Comerciais, dentre outras ${ }^{127}$. O monitoramento das decisões tomadas pela companhia, pode ser feito através das publicações das atas das Assembléias Gerais e das Reuniões do Conselho de Administração ou até mesmo diretamente na Junta Comercial do Estado da sede da companhia. O acompanhamento das deliberações tomadas pelos acionistas e administradores fornece um termômetro do relacionamento interno entre os acionistas e entre estes e os administradores, dos projetos em andamento, resultados da companhia e eventuais distribuições de resultados aos acionistas.

Algumas das formas mais utilizadas pelas companhias, para distribuição de receitas e bens aos seus acionistas, em prejuízo aos credores da companhia, é através da realização de mútuos para os acionistas, distribuição de dividendos, resgate de ações, redução de capital, aquisição das ações da própria sociedade $^{128}$ e alienação de ativos para empresas controladoras, coligadas ou

127 A atuação dessas empresas, para atribuir segurança aos investidores e as falhas verificadas nos controles e prestação de informações ao mercado, para os quais são contratadas, especialmente as empresas de auditoria externa, levou à criação de normas mais rígidas de conduta e adoção de sistemas internacionais de controle da atuação dessas entidades na prestação de informações ao mercado quanto aos resultados das companhias por elas analisadas.

${ }^{128}$ BLACK, Bernard e KRAAKMAN, Reinier. A Self-Enforcing Model..., pág. 53, defendo a criação de um modelo jurídico para países emergentes, que crie medidas que possibilitem aos acionistas e terceiros afetados pela atuação da companhia, controlar as deliberações e operações realizadas pela companhia, sem necessariamente exigir a atuação do judiciário (em uma tradução livre, seria um Modelo de AutoAplicação ou Auto-Cumprimento), sugerem que sejam estabelecidos parâmetros que permitam determinar se essas operações diminuíram injustificadamente seu patrimônio e se os valores praticados não condizem com os valores de mercado e, portanto, prejudicam os credores da companhia. Com a aplicação desses parâmetros, que envolvem a determinação dos valores aprovados para essas operações, em comparação com o valor do patrimônio da empresa, valores de mercado e valores contábeis, os credores ou até mesmo os tribunais que vierem a avaliar a validade dessas operações, poderão se certificar que não houve redução na solvência da empresa: "The simplest ways for a company to distribute assets to shareholders at the expense of creditors are through dividends (whether of cash, stock, or other property) and stock repurchases. From a creditors' perspective, these are identical transactions and should be regulated in the same manner. The self-enforcing model permits dividends or repurchases only if, after the payment, (i) the company will have net assets (assets minus liabilities) greater than zero, whether assets and liabilities are measured at book or at market value; and (ii) the company reasonably expects to be able to pay its bills as they come due. The first test is an asset test for the company' solvency; the second test is a liquidity test for solvency. (The requirement that the company repurchase stock at fair market value also provides some creditor requirement that the company repurchase stock at fair market also provides some creditor protection because if the company is close to insolvency, its shares willl have little value.) The market value test for asset-based solvency is familiar from developed coutries. We add the book value test because one cannot rely on courts in emerging markets to apply sensibly a rule that looks to market value to determine whether a company is insolvent after paying a dividend. We keep the market value test because book value may be an unrealistic measure of value. In Russia, for example, 
diretamente aos controladores e administradores, estes últimos através da utilização de terceiros a eles relacionados, para que não fique evidente o vínculo entre eles e se evite a caracterização flagrante do conflito de interesses. Essas operações não apenas afetam o patrimônio da companhia, como a integridade de seu capital que é, em última análise, a garantia dos credores.

Reconhecendo o prejuízo que os credores de uma companhia podem sofrer com reduções do capital realizadas sem justificativa e com intuito de esvaziar o patrimônio da empresa, a Lei das S.A. prevê, no artigo 173, apenas duas hipóteses para redução do capital: se houver perdas, até o montante dos prejuízos acumulados ou se o capital for julgado excessivo em relação às atividades da companhia. A fim de proteger os credores da companhia, o artigo 174 determina que, independentemente da justificativa para redução do capital, a deliberação que aprova esta operação somente se tornará efetiva, após 60 dias contados da publicação da ata da Assembléia Geral que a houver aprovado. Durante esse prazo, os credores quirografários com títulos anteriores à data da publicação da ata poderão notificar a companhia e se opor à redução do capital, dando ciência da notificação à Junta Comercial da sede da companhia. Se houver oposição de algum credor à redução do capital, esta somente se efetivará se comprovado o pagamento do crédito ou realização do depósito judicial dos valores devidos.

Com relação à distribuição de dividendos, o artigo 201 determina que a companhia somente poderá pagar dividendos à conta do lucro líquido do exercício, de lucros acumulados e de reserva de lucros, com exceção do pagamento de dividendos aos preferencialistas, que podem ser pagos à conta de reserva de capital. Desta forma, como a deliberação sobre distribuição de dividendos somente poderá ocorrer quando forem conhecidos os resultados do exercício e o balanço tiver sido levantado. Ainda que o Estatuto Social, nos termos do artigo 204, permita a distribuição de dividendos intermediários, em períodos menores que um exercício social, a companhia deverá, para tanto, levantar balanço intermediário, sobre o qual os administradores deliberarão sendo, neste caso, os dividendos pagos sobre os lucros

many intercompany debts that will never be paid are listed as assets by the company to whom they are nominally owed." 
apurados nesse balanço intermediário ou à conta de lucros acumulados ou de reserva de lucros existentes no último balanço anual ou semestral.

A distribuição de dividendos com inobservância dessas disposições responsabiliza solidariamente os administradores e fiscais que autorizaram a distribuição - no caso dos dividendos intermediários -, ou que a realizaram, em cumprimento à deliberação dos acionistas, devendo repor à companhia os valores distribuídos, que responderão ainda a ação penal que couber no caso ( $§ 1^{\circ}$ do art. 201). A ação para que os acionistas, os administradores ou titulares de partes beneficiárias restituam os dividendos ou participações no lucro recebidas de má-fé, prescreve em 3 anos, iniciando-se da data da publicação da ata da assembléia geral ordinária do exercício em que os dividendos ou participações tenham sido pagas ${ }^{129}$. As ações contra os administradores que aprovaram a distribuição dos dividendos em desacordo com as disposições legais, para que estes reponham ao caixa os valores distribuídos, prescreve no mesmo prazo, mas o prazo inicia-se da data da publicação da ata que aprovou o balanço referente ao exercício em que a distribuição ocorreu ${ }^{130}$.

Outra operação, apontada por Bernard Black e Reinier Kraakman que tem o potencial de prejudicar credores, por diminuir o patrimônio da companhia e alterar artificialmente o valor de negociação das ações no mercado ou transferir, aos acionistas, valores muito superiores aos que valeriam suas ações, é a aquisição de ações da própria companhia. O legislador brasileiro, reconhecendo esse risco, estabeleceu no art. 30 a proibição da companhia negociar as próprias ações, com exceção das seguintes hipóteses: (a) operações de resgate, reembolso ou amortização previstas em lei; (b) aquisições por doação ou para permanência em tesouraria ou cancelamento, até o valor do saldo de lucros ou reservas, com exceção da reserva legal e sem diminuição do capital social; (c) alienações das ações adquiridas nos termos do item "b" acima e mantidas em tesouraria; ou (d) aquisições das ações relativas à parcela do capital reduzido, quando o preço dessas ações adquiridas em bolsa for inferior ou igual à importância que deverá ser restituída em dinheiro.

\footnotetext{
${ }^{129}$ Conforme itens "c" e "d" do inciso II, do artigo 287.

${ }^{130}$ Conforme item "b" do inciso II do artigo 287.
} 
Por fim, com relação à venda substancial de ativos ou de ativos essenciais para realização das atividades da empresa ${ }^{131}$, os credores da companhia deverão permanecer atentos quanto às condições e valores da operação aprovada e o impacto de sua realização para o patrimônio da empresa e para as garantias dos credores. Neste caso também será fundamental que os acionistas e administradores apresentem as justificativas econômicas e os benefícios que a realização dessas operações trarão à companhia, o que auxiliará os credores a avaliar a situação econômica e financeira em que ficará a companhia após essas operações e se essas operações estão de acordo com as práticas e condições do mercado, à época em que foram aprovadas.

Não obstante as operações de mútuo para acionistas, distribuição de dividendos, recompra de ações, reduções de capital e alienação de ativos sejam as formas mais freqüentes com que os credores e até mesmo acionistas são prejudicados pela diminuição do patrimônio da sociedade, quando essas deliberações não visam atender aos interesses da companhia, é necessário estabelecer limites e não simples impedimentos para que sejam realizadas, pois são necessárias para a condução ordinária dos negócios sociais. O grande problema enfrentado para averiguar a legitimidade dessas operações é a comprovação de que visam o interesse da companhia. Essa análise exige a avalição se os termos e condições negociadas são condizentes com as práticas de mercado e se os administradores e acionistas que as aprovaram agiram de boa-fé e com lealdade para com a companhia e os demais acionistas e estavam munidos das informações necessárias. Se a decisão tomada trouxe prejuízos à companhia, poderá ser atacada caso comprovado que os valores e condições da operação estavam em desacordo com os valores e condições praticados pelo mercado e que os administradores e acionistas não foram diligentes em verificar as melhores condições para sua realização no interesse da companhia, e ainda se sua realização acarretou prejuízo à companhia ou a terceiros, por acarretar uma diminuição injustificada e

\footnotetext{
${ }^{131}$ Essas operações também podem vir a ser anuladas se comprovado que foram aprovadas por acionistas ou praticada por administradores que possuam interesse conflitante com o da companhia e que sejam favorecidos, em detrimento da empresa, pela aprovação da deliberação. As conseqüências, para a companhia e seus acionistas, da aprovação de deliberações e prática de atos, em conflito de interesses, será analisada adiante, no Capítulo IV.1.
} 
excessiva de seu patrimônio que comprometa sua solvência e o pagamento das obrigações assumidas pela empresa ${ }^{132}$.

Caso comprovado que os acionistas e administradores agiram no melhor interesse da companhia, estavam informados e tomaram as cautelas necessárias para que o negócio fosse realizado nas melhores condições de mercado à época da sua aprovação, ainda que a companhia venha a sofrer prejuízos ou diminuição de patrimônio, os credores não poderão atacar a validade da operação. Poderão sim, se precaver de prejuízos e requerer reforços de garantias e rever as condições para realização de negócios com essa empresa, mas a decisão tomada será legítima e não poderá ser atacada para tentar obter sua anulação e eventual responsabilização dos acionistas ou administradores que a aprovaram.

Outro aspecto, expressamente previsto no parágrafo único do artigo 116 da Lei das S.A. a ser considerado como interesse limitador ao exercício do poder de controle e às atividades da empresa, diz respeito aos empregados da companhia. As decisões administrativas da companhia afetam diretamente seus trabalhadores e, reconhecendo a necessidade de preservação dos seus interesses, diretamente relacionados aos interesses da comunidade em que a empresa atua, a Lei 10.303 de 2001, introduziu o parágrafo único do artigo 140, prevendo a posibilidade de o Estatuto Social conter previsão de eleição, para o Conselho de Administração, de representantes dos empregados, escolhidos pelo voto destes, em eleição direta, organizada pela empresa, em conjunto com as entidades sindicais que os representem.

A proteção dos interesses dos trabalhadores assume maior importância em momentos de crise financeira generalizada, em que os cortes de

\footnotetext{
${ }^{132}$ BLACK, Bernard e KRAKMAN, Reinier. A Self-Enforcing Model..., pág. 54, propõem que sejam verificados os seguintes parâmetros que, embora sejam vagos, estabelecem um ponto de partida para verificar a validade da operação e a existência de prejuízos aos credores e acionistas: "Although dividends and stock repurchases by a company that is in or near insolvency are particularly suspect as asset distributions, any corporate transaction can be a vehicle for extracting assets from the company, to the detriment of creditors and often shareholders as well. The challenge is how to block bogus transactions without impeding ordinary business dealings. Here we can do no better than the vague standard, familiar from fraudulent conveyance law, that a transaction is improper if (i) the company does not receive equivalent value, and (ii) the company fails an asset-based or liquidity-based solvency test after the transaction. We again use both book and market value tests for asset solvency."
} 
empregados são um dos primeiros instrumentos utilizados para redução dos $\operatorname{custos}^{133}$. Nesse sentido, a atuação estatal, através da disponibização de recursos para empresas em dificuldades ou em condições mais favoráveis que as praticadas pelo mercado, possibilita estabelecer condições para que essas empresas mantenham seus empregados e, portanto, preservem o interesse social envolvido na geração de empregos.

Os meios para obter a reparação dos danos causados, pela sociedade controladora à sua controlada, com infração ao disposto nos arts. 116 e 117, estão previstos no artigo 246 da Lei 6.404. No entanto, como comentado anteriormente, o parágrafo único do artigo 116 determina que o controlador tem deveres e responsabilidades para com os demais acionistas da companhia, os que nela trabalham e para com a comunidade em que atua, cujos direitos e interesses deve lealmente respeitar e atender. No entanto, o $\S 1^{\circ}$ do artigo 246 determina que a ação para haver reparação, do controlador, pelos prejuízos causados à companhia cabe, aos acionistas que representem $5 \%$ ou mais do capital social ou a qualquer acionista, desde que preste caução pels custas e honorários advocatícios devidos no caso da ação vir a ser julgada improcedente. Esse dispositivo não confere legitimidade, portanto, às demais pessoas indicadas no parágrafo único do artigo 116, cujos direitos e interesses são de observância obrigatória pelo controlador.

Sob este fundamento, a Ministra Nancy Andrighi, em VotoVista (vencido) proferido nos autos do REspecial $\mathrm{n}^{\mathrm{o}}$ 633.338-DF ${ }^{134}$ defendeu entendimento “...que, não obstante o art. 246 faça referência aos arts. 116 e 117, ele

\footnotetext{
${ }^{133}$ Muitas das empresas afetadas pela crise desencadeada em setembro de 2008 recorreram a recursos públicos, principalmente do Banco Nacional de Desenvolvimento Econômico e Social - BNDES, para equilibrar suas contas e permitir a continuidade de suas atividades. Um dos objetivos institucionais desse órgão é fomentar investimentos nas empresas brasileiras e aumentar a oferta de empregos. Conforme noticiado pelo jornal Folha de São Paulo, em 22 de janeiro de 2009 (disponível em http://www1.folha.uol.com.br/fsp/dinheiro/fi2201200914.htm), acesso em 22.01.2009, a liberação desses recursos estava condicionada à manutenção dos empregos, devendo o BNDES aprovar os programas de demissões que fossem aplicados, apesar desse jornal informar que os setores que mais demitiram no período de janeiro a novembro de 2008 foram justamente os que receberam mais recursos do BNDES. Também conforme noticiado pela impresa, no dia 22 de janeiro de 2009 (disponível em http://www.valoronline.com.br/ValorImpresso/MateriaImpresso.aspx?\&tit=Com+BNDES,+VCP+assume $+\mathrm{a}+$ Aracruz\&dtmateria $=21 / 01 / 2009 \&$ codmateria $=5375482 \&$ codcate goria $=95 \& t \mathrm{p}=437337937$ ), $\quad$ acesso em 22.01.2009, o aporte de capitais, pelo BNDES, na operação de aquisição do controle da Aracruz pelo grupo Votorantim foi justificado pelo BNDES pela necessidade de viabilizar o desenvolvimento de uma empresa brasileira competitiva no mercado internacional, no setor de celulose e, ao mesmo tempo, considerando as perdas financeiras verificadas pela Aracruz no final de 2009, garantir a manutenção de empregos.

${ }^{134}$ Julgado em 05.09.2006, DJ 04.12.2006.
} 
não esgota as hipóteses em que esses dispositivos têm aplicação. As demandas da sociedade, representada pelos minoritários (como bem observado pelo i. Relator), exercem-se da forma disposta no art. 246. As demais pretensões que nascem do descumprimento dos princípios estabelecidos nos arts. 116 e 117, a serem propostas por terceiros prejudicados, não se regulam por essa norma."

Desta forma, os terceiros afetados pelos atos praticados pelo acionista controlador, na forma dos arts. 116 e 117 poderiam ajuizar ação para ressarcimento dos prejuízos causados, com base nos arts. 592, II e $596^{135}$ do Código de Processo Civil.

135 “Art. 592. Ficam sujeitos à execução os bens: (...) II - do sócio, nos termos da lei;” “Art. 596. Os bens particulares dos sócios não respondem pelas dívidas da sociedade senão nos casos previstos em lei; o sócio, demandado pelo pagamento da dívida, tem direito a exigir que sejam primeiro excutidos os bens da sociedade." 


\section{III.3. - INTERESSES SOCIAIS}

A constituição de uma companhia, como ente jurídico autônomo, com personalidade jurídica e patrimônio próprios é realizada com a harmonização dos interesses de seus sócios e a determinação das regras de convivência desses interesses, permitindo a gestão da sociedade para realização das atividades econômicas delimitadas em seus atos constitutivos, com a obtenção e distribuição dos lucros aos acionistas.

A companhia passa a concentrar e irradiar direitos e deveres, decorrentes da realização de seu objeto social e, com isso, torna-se um centro de interesses autônomo em relação a seus sócios, necessário para manutenção de sua autonomia patrimonial e administrativa. Com essa estrutura, se procura evitar que os interesses pessoais dos sócios, que estiverem em desacordo com aquelas normas de convivência e objetivos comuns que possibilitaram a constituição da companhia, coloquem em perigo sua sobrevivência.

A constatação de que os próprios sócios, controladores ou minoritários, poderão agir em prejuízo da companhia, levou o legislador a criar mecanismos de proteção aos interesses da sociedade, determinando que estes prevaleçam, ainda que em face dos interesses pessoais dos sócios, quando conflitantes.

As teorias contratualista e institucionalista são as teorias clássicas que analisaram e procuraram explicar o fenômeno da constituição das sociedades sob diferentes enfoques e cada uma delas reflete os valores sociais e econômicos da época em que foram desenvolvidas. Na teoria contratualista clássica ${ }^{136}$, as sociedades são instrumentos da vontade de seus sócios, os quais se unem para colaborar mutuamente na realização da finalidade social. De acordo com essa teoria, a

\footnotetext{
${ }^{136}$ Que teve se desenvolveu no contexto individualista e liberal, dos séculos XVIII e XIX que privilegiam a liberdade dos indivíduos, em regular e livremente associar-se, determinando as regras aplicáveis às suas relações pessoais.
} 
vontade dos sócios em realizar a finalidade para a qual a sociedade foi constituída confunde-se com a vontade da sociedade e é determinante da estrutura interna da sociedade, merecendo proteção legal específica.

Sob o enfoque da teoria institucionalista ${ }^{137}$, a sociedades são analisadas de acordo com sua função econômica e o interesse público envolvidos nas suas atividades ${ }^{138}$. Elementos de direito público são aplicados para análise das companhias, a qual é considerada uma comunidade de trabalho, unificando um grupo de pessoas voltadas para um interesse superior à simples produção e circulação de riquezas, em que o interesse público prevalece sobre os interesses particulares dos sócios, sendo necessário protegê-la e preservá-la para que possa continuar suas atividades, além da obrigação de atender aos interesses públicos e dos trabalhadores envolvidos na realização do objeto social $^{139}$.

Atualmente, diversos elementos de ambas as teorias são aplicados na análise e conceituação das sociedades, especialmente as por ações. Não obstante constituir-se através de um contrato plurilateral, a Lei das S.A. consagra diversos elementos institucionais, principalmente em decorrência da necessidade de proteção a interesses externos à companhia ${ }^{140}$.

\footnotetext{
${ }^{137}$ Conforme Calixto Salomão Filho, O NovoDireito Societário. São Paulo: Malheiros, 2002, pág. 31 essa teoria se desenvolveu na inicialmente na Alemanha, por W. Rathenau, após a Primeira Guerra Mundial, o qual, influenciado pelas dificuldades enfrentadas por seu país à época, identificava, nas grandes sociedades, um instrumento valioso para o renascimento econômico nacional, voltado para a realização dos interesses sociais e econômicos alemães, e não para a realização dos interesses pessoais dos sócios.

${ }^{138}$ As companhias de economia mista, atendem a princípios diversos, voltados ao interesse público de realização de uma determinada atividade, que levou à autorização legislativa para criação daquela sociedade, se sobrepõe aos interesses particulares dos demais sócios e ainda ao objetivo final de maximização dos resultados dos investimentos realizados. $\mathrm{O}$ art. 238 da Lei das S.A. prevê que o acionista controlador da companhia de economia mista tem os mesmos deveres e responsabilidades do acionista controlador de uma S.A., mas deve orientar as atividades sociais para a realização dos interesses públicos que justificaram sua criação, ainda que isso acarrete uma redução nos lucros da companhia. No entanto, a sociedade de economia mista somente poderá explorar os empreendimentos ou exercer as atividades previstas na lei que autorizou sua constituição.

${ }^{139}$ REQUIÃO, Rubens. Curso de Direito Comercial. 23 ${ }^{a}$ Edição. São Paulo: Saraiva, 2003, vol. 2, pág. 275.

${ }^{140}$ REQUIÃO, Curso..., sustenta, com base na "Exposição de Motivos" da Lei das S/A, que as sociedades por ações, embora constituídas através de contrato plurilateral, podem configurar, em algumas situações, quando em funcionamento, uma instituição, pág. 15: "O mal, entretanto, do projeto de reforma, que se refletiu no sistema da lei hoje em vigor, foi precisamente o de não ter percebido que, quando se pode admitir que a sociedade anônima configure, após sua formação, uma instituição, não deixa ela de ser formada pelo contrato, e este da espécie plurilateral. Como instituição está ela voltada para a consecução do "bem comum", visando primacialmente aos altos interesses coletivos, desvanecendo um tanto o interesse privado, perseguido pelos acionistas. Como contrato regula os interesses pessoais de seus membros."
} 
O reconhecimento da existência de interesses da sociedade, autônomos em relação aos de seus sócios, não confere caráter institucional às S.A. na medida em que os interesses sociais não estão acima dos interesses dos sócios e nem estão deles totalmente desvinculados. Como observa Rodrigo Ferraz Pimenta da Cunha $^{141}$ : “Apesar de partirem as teorias (contratualista e institucionalista) de fundamentos diversos, da interpretação das relações internas da companhia como um contrato ou como uma instituição, chegam, ao final, a produzir o mesmo efeito: a constatação de que são distintos os interesses dos sócios coletivamente considerados e os da sociedade. Para os contratualistas, o interesse do sócio enquanto sócio (uti socii); para os institucionalistas, um interesse autônomo da companhia, que também é alcançado pela expressão dos acionistas por meio dos órgãos sociais." ${ }^{142}$

A dificuldade de conceituação do interesse da companhia em relação aos interesses particulares dos sócios e de terceiros que a lei reconhece devem ser observados, também foi enfrentada por Alfredo Lamy Filho e José Luiz Bulhões Pedreira ${ }^{143}$, filiando-se à teoria contratualista: “O 'interesse da companhia' não é um 'interesse superior', estranho e acima da vontade comum dos sócios, ou um 'interesse da empresa em si', a ser descoberto para o juiz, e capaz de anular a deliberação social, mesmo unânime. A discussão sobre a matéria prosperou em sistemas legislativos que não tinham feito opção expressa por um comando legal na matéria, como fez a lei brasileira, a exemplo do que já haviam feito a legislação italiana (Cód. Civil, art. 2.373, caput, 'o direito de voto não poderá ser exercido pelo sócio nas deliberações em que tenha, por conta própria ou de terceiros, um interesse em conflito com o da sociedade');

${ }^{141}$ Estrutura de Interesses..., pág. 116.

${ }^{142}$ Também neste sentido, MUNHOZ, Eduardo Secchi, Empresa Contemporânea..., pág. 48: "É interessante notar que essa visão do interesse social, aliando interesses internos e externos, encontra origem ainda nas teorias contratualista e institucionalista. Uma vertente da teoria contratualista inclui na categoria de sócios não apenas os atuais, mas também os futuros, em enfoque de longo prazo que realça a importância da preservação da empresa, como elemento do interesse social. Por outro lado, a teoria institucionalista tem uma vertente 'integracionista', que se afasta do tom publicístico exagerado de Rathenau, para conceber o interesse social como o interesse harmônico e comum dos vários tipos de sócios e trabalhadores, que se traduz no interesse pela preservação da empresa. Essas duas vertentes da teoria contratualista e institucionalista acabam por aproximá-las, de modo a reconhecer como interesses a serem necessariamente protegidos, de um lado, a produção de lucro e, de outro, os interesses dos trabalhadores e da comunidade na preservação da empresa." Verifique-se também o entendimento de SIMIONATO, Frederico Augusto Monte. Estrutura de Interesses..., pág. 174: “A empresa não está somente nos sócios, nos trabalhadores, nos consumidores ou nela própria. A empresa é a junção de todos esses fatores. O desequilíbrio de um, apenas, já causa o desequilíbrio do sistema. O interesse individual deve dar lugar ao interesse social, que não é a 'somatória' dos demais, ms é a sua complementariedade."

${ }^{143}$ A Lei das S.A...., vol. 2, pág. 238. 
a alemã (Lei de S.A., de 1965, art. 243: 1 - as deliberações da assembléia são impugnáveis por violação da lei ou do ato constitutivo; 2 - a impugnação pode também ser fundada no fato de ter o acionista visado com o exercício do voto obter vantagem particular para si ou para terceiro, em prejuízo da sociedade ou dos outros acionistas, e a deliberação seja capaz de servir à realização desse escopo); ou a espanhola (art. 67 da Lei das S.A., de 1951: 'poderão ser impugnados, segundo as normas e dentro dos prazos estabelecidos nos artigos seguintes, as deliberações sociais que sejam contrárias à lei, se oponham aos estatutos ou lesem, em benefício de um ou de vários acionistas, os interesses da sociedade'); e outras mais. O voto deve, pois, ser exercido 'no interesse da companhia' identificado como o 'interesse comum dos sócios'”.

Frederico Augusto Monte Simionato ${ }^{144}$ enfoca a importância da consideração do indivíduo como ponto central da existência da sociedade, considerada como organização dos meios de produção e para análise das situações envolvendo a empresa e a coletividade, em razão da necessidade de cumprir sua função social o que ressalta os aspectos institucionais que interferem na administração das sociedades por ações.

Como meio de proteger os interesses sociais, em face dos interesses de seus sócios e garantir a utilização da estrutura societária de forma legítima, sem acarretar prejuízos aos interesses externos à companhia e que com ela interagem e que o sistema jurídico procura proteger, a própria Lei das S.A. trata de estabelecer os limites que os interesses dos sócios encontram, dentro da sociedade, na participação nas Assembléias Gerais, além de determinar os princípios e limites externos que a vontade social encontra na realização de seus interesses.

\footnotetext{
${ }^{144}$ Sociedades Anônimas..., pág. 174 e 175: “A empesa como organização deve levar em consideração o aspecto externo da atividade, e para isto o aspecto das relações intra-societárias pode realmente ser mitigado. Acontece que a relação empresa-coletividade deverá ser feita colocando o homem no centro de sua existência (como destinatário único), e para ele a empresa deve existir, cumprindo a função que lhe foi entregue pelo próprio capitalismo. Entre suas obrigações está o respeito ao consumidor, ao meio ambiente, a qualidade dos produtos etc. A perpesctiva do indivíduo quanto à empresa não pode ser confundida com a do sócio para com a sociedade. É neste passo que a administração se institucionaliza, e a sociedade que foi fundada torna-se organização. O contrato originário da vontade inicial dissipa-se diante da atividade organizada."
} 
Conforme lição de Fábio Konder Comparato ${ }^{145}$, o interesse da sociedade identifica-se com o "interesse comum" a todos os sócios: a participação nos lucros e no patrimônio social e que todos os sócios devem observar e perseguir, independentemente de seus interesses particulares ${ }^{146}$ : "Quando a lei usa da expressão 'interesse da companhia', está referindo-se ao interesse do acionista 'enquanto tal', ao modelo jurídico de acionista, abstratamente considerado; e não a determinado indivíduo que figura concretamente como acionista de determinada companhia. Assim, enquanto os acionistas Caio, Túlio ou Semprônio podem apresentar interesses individuais os mais variados, dentro e fora da sociedade anônima, o interesse geral de todo acionista, no mecanismo jurídico societário, é um só e sempre igual a si mesmo: a participação nos lucros e no acervo da companhia, refletida no valor de suas ações. 9. Os termos do eventual conflito tornam-se, dessa forma, mais compreensíveis, dissipada a confusão terminológica. Ao falar em 'interesse da companhia', a lei se refere ao 'interesse comum' dos acionistas, igual para todos, pois que corresponde ao modelo jurídico sobre o qual se elaborou o instituto."

A consecução da atividade econômica, pela companhia, através da correta administração da empresa e cumprimento das obrigações de seus administradores com resultados positivos e distribuição de lucros aos sócios, permite atender aos interesses dos sócios (internos) e de seus credores (externos), atingindo, assim, o interesse final da sociedade. ${ }^{147}$

\footnotetext{
145 Direito Empresarial: Estudos e Pareceres. São Paulo: Saraiva. 1990, pág. 88.

${ }^{146}$ No mesmo sentido, HALPERIN, Isaac e OTAEGUI, Julio C. Sociedades Anônimas..., pág. 216: "El interés social radica em la realización de cuanto es idóneo para satisfacer el objeto social y que se resuelve em uma satisfacción proporcional del interés individual de cada socio. La noción de interés es objetiva (no psicológica), y se lo apreciará en concreto.” Os autores reproduzem trechos de alguns julgados da Câmara Nacional de Comércio Argentina, em que adota-se o conceito de interesse social como o resultante dos "limites impostos pelo objeto social concreto ou que resultem dos fins perseguidos e da atividade a ser realizada, segundo a natureza da empresa, o desenvolvimento, a produtividade e a conservação da organização."

${ }^{147}$ VITRÒ, Vincenzo, em Controllo Giudiziário, apud QUATRARO, Bartolomeo e TOSI, Emilio. Il Controllo Giudiziario...., pág. 176, assim se manifesta: "E se si vuole porre l'accento sugli interessi, questi, per definizione, atteso che la società per azioni è um ente privato, che sta nel mercato, per realizzare esclusivamente profitti (nessuno finora è riuscito a dimostrare il contrario in relazione al diritto positivo), sono gli interessi dei soci e dei creditori sociali ad uma ordinata gestione dell'impresa sociale ed al rispetto delle regole poste dall'organizzazione."
} 
O artigo 2247 do Código Civil Italiano ${ }^{148}$ estabelece que o escopo do contrato de sociedade é a divisão de lucros entre os sócios, através da realização, em comum, de uma atividade econômica. Partindo dessa definição, Cinzia Gamba identifica o interesse social como o "interesse típico, objetivo e imutável" de produzir lucros através do exercício, em comum, pelos sócios, da atividade prevista no contrato de sociedade ${ }^{149}$.

Com base nessas premissas, nas situações em que haja fundada suspeita de ocorrência de lesão ou desvio do interesse social na forma de uma decisão ou realização de uma operação, o juiz deverá analisar a situação fática apresentada e os interesses pessoais dos acionistas e administradores envolvidos, para somente então determinar qual medida ou decisão seria benéfica aos interesses da companhia e se, naquela situação, ocorreu abuso do direito, conflito de interesses ou abuso do poder de controle, por parte dos acionistas que aprovaram a deliberação e se esta, por estar viciada, é anulável.

Para isso, diversos fatores deverão ser analisados pelo juiz na análise da situação envolvendo a decisão impugnada: o objeto social da sociedade, sua composição societária, o Estatuto Social, os atos impugnados, os interesses e posições de cada um dos acionistas, especialmente os titulares do poder de controle, dentre outros, para somente então, decidir quanto à ocorrência de violação aos interesses da sociedade e anulação da deliberação tomada e eventual pagamento de indenização à sociedade.

Desta forma, o elemento principal de que deve partir a análise do juiz, nas análises das situações em que se pleiteia uma medida judicial que interfira nas atividades de uma companhia ou que envolva a análise de atos praticados pelos administradores ou votos proferidos por acionistas, é a verificação se as decisões tomadas ou atos praticados que estão sob análise buscaram atender aos interesses da companhia e não interesses particulares dos sócios ou administradores, ainda que o

\footnotetext{
148 “Art. 2247. Con il contratto di società due o più persone conferiscono beni o servizi per l'esercizio in comune di un'attività economica allo scopo di dividerne gli utili."

${ }^{149}$ Dirito Societario..., pág. 122: "L'interesse sociale è stato identificato com l'interesse típico, oggettivo ed immutabile alla produzione degli utili e all'esercizio in comune di tale attività, derivante dalla causa del contratto di società."
} 
resultado financeiro ou estratégico da deliberação, para a companhia, não tenha sido positivo.

A persecução dos interesses da sociedade, na tomada das decisões que envolvem suas atividades e nas deliberações sociais, respeitados os interesses externos envolvidos na realização dessas atividades (parágrafo único do art. 116) é que garante a legitimidade dessas decisões, ainda que terceiros ou os próprios acionistas possam sofrer prejuízos ${ }^{150}$.

A manifestação da vontade social ocorre através das deliberações tomadas em Assembléia Geral, obedecidas as prescrições legais de convocação e instalação. A execução das determinações dos acionistas, tomadas nas Assembléias Gerais e a representação da sociedade ocorrem através de seus órgãos, a quem são normalmente destinadas as deliberações tomadas ${ }^{151}$. Assim, se a deliberação que autorizou um determinado ato foi anulada, sob o fundamento de que sua aprovação não buscou alcançar o interesse social, também o ato praticado em cumprimento a essa deliberação deve ser anulado, observados os direitos de terceiros de boa-fé.

A motivação que leva à aprovação de determinadas deliberações, no interesse da companhia, é fundamental para preservação da integridade dos princípios patrimoniais que caracterizam esse tipo societário. O sistema jurídico italiano prevê, em casos extremos, o afastamento dos administradores de seus cargos e nomeação de um administrador judicial, na forma do art. 2409 do Código Civil Italiano $^{152}$, que será comentado adiante, com o objetivo de corrigir e evitar situações de

\footnotetext{
${ }^{150}$ REsp nº 602.229, j. 26.10.2004, $3^{\mathrm{a}}$ Turma do STJ, Relator Ministro Carlos Alberto Menezes Direito, v.u.: "Sociedade anônima. Negociação com as próprias ações. Permuta com bem imóvel da companhia. Art. 30 da Lei $n^{\circ}$ 6.404/76. 1. A companhia não pode negociar com suas próprias ações sem que tenham sido preenchidos os pressupostos do art. 30 e seu $\S 1^{\circ}$ da Lei $n^{\circ} 6.404 / 76$. No caso, não demonstrado que a negociação considerou o interesse da sociedade, e que feita até o valor do saldo de lucros ou reservas, exceto a legal, e sem diminuição do capital social (letra b), é inviável deferir-se o cumprimento do contrato de permuta envolvendo ações de emissão da própria companhia. 2. Recurso especial conhecido e provido." (Grifo nosso)

${ }^{151}$ Erasmo Valladão Azevedo e Novaes França. Invalidade das Deliberações de Assembléia das S.A., pág. 61: "As deliberações da assembléia geral têm como destinatários, normalmente, os administradores. Através deles - especificamente dos diretores, a quem compete a representação da companhia, nos termos do art. 144 da Lei n. 6.404/76 -, é que a sociedade (e não a assembléia) entrará em contato com terceiros." 152 “Art. 2409 Denunzia al tribunale Se vi è fondato sospetto di gravi irregolarità nell'adempimento dei doveri degli amministratori e dei sindaci, i soci che rappresentano il decimo del capitale sociale possono denunziare i fatti al tribunale. Il tribunale, sentiti in camera di consiglio gli amministratori e i sindaci, può ordinare (att. 103) l'ispezione dell'amministrazione della società a spese dei soci richiedenti,
} 
"grave irregularidade", "...pelo descumprimento das obrigações dos administradores, na condução dos negócios sociais, que possam prejudicar o prosseguimento da atividade econômica da sociedade e realmente ameaçar a existência da própria sociedade... "153.

A legislação brasileira não possui regra semelhante. A constatação de que um administrador praticou atos contrários aos interesses da sociedade e descumpriu algum dos deveres a ele impostos por lei, possibilita a destituição, inclusive judicial, de seu cargo e pagamento de indenização à sociedade. No caso dos acionistas não conseguirem chegar a um acordo quanto à nomeação de novos administradores ou em caso de grave desentendimento que impossibilite aprovar alguma deliberação, levando à paralisia da empresa, o juiz poderá intervir de forma pontual para aprovar uma determinada deliberação, mediante desempate, como permite o parágrafo $2^{\circ}$ do art. 129 da Lei 6.404/76, se o Estatuto não estabelecer procedimento de arbitragem e não contiver norma diversa, e, permanecendo o empate, os acionistas não concordarem em cometer a decisão a um terceiro..

A paralisia continuada dos órgãos sociais, quando ameace a existência da empresa, poderá, em casos extremos, nos termos do art. 206 da Lei das S.A., levar à sua dissolução total ou parcial, quando requerida por acionistas representando, no mínimo, $5 \%$ de seu capital social, quando comprovado que ela não pode mais preencher seus fins.

A fim de amenizar essa conseqüência, tão drástica para a sociedade, a jurisprudência desenvolveu o instituto da dissolução parcial de sociedades por ações, para permitir mante-la funcionando, quando economicamente viável, a estrutura societária ou parte dela, com a retirada, de seus quadros societários, dos

subordinandola, se del caso, alla prestazione di una cauzione (Cod. Proc. Civ. 119). Se le irregolarità denunziate sussistono, il tribunale può disporre gli opportuni provvedimenti cautelari e convocare l'assemblea per le conseguenti deliberazioni. Nei casi più gravi può revocare gli amministratori ed i sindaci e nominare un amministratore giudiziario, determinandone i poteri e la durata (2636). L'amministratore giudiziario può proporre l'azione di responsabilità contro gli amministratori e i sindaci. Prima della scadenza del suo incarico l'amministratore giudiziario convoca e presiede l'assemblea per la nomina dei nuovi amministratori e sindaci o per proporre, se del caso, la messa in liquidazione della società (2636). I provvedimenti previsti da questo articolo possono essere adottati anche su richiesta del pubblico ministero, e in questo caso le spese per l'ispezione sono a carico della società (2488; att. 103, 209)."

${ }^{153}$ VITRÒ, Vincenzo. Controllo Giudiziario..., apud QUATRARO, Bartolomeo e TOSI, Emilio, Il Controllo Giudiziario....., pág. 177. 
acionistas que não tiverem interesse em dela participar, pretenderem sua dissolução ou ainda colocarem em risco sua existência, preservando-se assim os interesses da sociedade na realização de suas atividades e atendimento de sua função.

Ainda que a dissolução de uma sociedade não seja requerida em razão da desinteligência grave entre os sócios, mas para atendimento de interesses externos à companhia, muitas vezes em benefício de uma outra empresa, pertencente ou não ao mesmo grupo econômico, os interesses externos à companhia e os dela própria, quando verificada a viabilidade de sua manutenção produtiva, possibilitam a interferência na decisão, para resguardar interesses maiores, inclusive econômicos nacionais. $^{154}$

${ }^{154}$ SIMIONATO, Frederico Augusto Monte. Sociedades Anônimas..., pág. 66, pondera que a criação e aumento do poder conferido às macroempresas, aumenta o poder gerencial, alienando os acionistas das motivações quanto à tomada da maioria das decisões, importanto apenas o lucro, o que diminui a influência dos interesses sociais na condução dos negócios: "No controle gerencial a diretoria comanda a empresa. Essa tecnocracia altamente treinada possibilita a realização de grandes negócios para a empresa, tornando-a rentável e deixando os acionistas tranqüilos e completamente alheios à política social. Por isso do controle sobre a administração das companhias quando manipulam o mercado, ou impõem política contrária à empresa do próprio grupo, como o fechamento de companhia próspera. Está cada vez mais corriqueira a aquisição de empresas brasileiras por conglomerados internacionais, com o encerramento ou reorganização das atividades produtivas." 


\section{IV - A INTERVENÇÃO JUDICIAL NA ADMINISTRAÇÃO DAS S.A.}

Aurélio Wander Bastos ${ }^{155}$, analisando a jurisprudência societária brasileira como instrumento crítico da sociedade e seu papel no processo de adaptação legislativa às transformações sociais e empresariais que vêm ocorrendo em todo o mundo, conclui que o Poder Judiciário, no Brasil, pelo menos no que se refere ao direito empresarial, restringe sua atuação aos limites das próprias normas jurídicas, não exercendo o papel que lhe cabe de "instrumento crítico da sociedade": "As linhas conclusivas desta pesquisa nos permitiram consolidar a nossa hipótese teórica inicial de que a Jurisprudência só é um instrumento crítico da sociedade nos limites permissíveis pela própria ordem jurídica, e não pela sociedade. Portanto, interpretar juridicamente a realidade social com a metodologia da própria norma circunscreve, como os resultados da pesquisa demonstram, o ato de interpretar aos limites da própria ordem jurídica. Daí, como constatamos, as limitações adaptativas da Jurisprudência ao processo de mudança social são, particularmente, dificultadas pelo acanhamento estrutural do Poder Judiciário. Estas dificuldades críticas dos atores judiciários inibem a produção jurisprudencial e, mais que isto, denunciam uma jurisprudência vinculada, própria dos modelos centralizados de criação jurídica. O juiz, mais do que aos "casos", à experiência socialmente vivida, está sujeito aos parâmetros normativos, o que reduz e circunscreve a dinamicidade da ordem jurídica e dá à interpretação judicial este caráter vinculante, ou acentuadamente dependente da lei."

Os resultados da pesquisa realizada por Aurélio Wander Bastos e Nelson Laks Eizirik, apresentados no livro O Poder Judiciário e a Jurisprudência sobre Sociedades Anônimas e Instituições Financeiras, 6 anos após a promulgação da atual Lei das S.A., demonstram que a atuação do Poder Judiciário como intérprete dos conceitos legais e instrumento de adaptação de novos fatos e de uma nova realidade

${ }^{155}$ O Poder Judiciário e a Jusrisprudência sobre Sociedades Anônimas e Instituições Financeiras. Rio de Janeiro: IBMEC, 1980, pág. 8. 
social às normas jurídicas positivadas, tem sido muito tímida e pouco tem acrescentado para a formação de uma jurisprudência que ofereça linhas de interpretação das normas positivas de forma coerente com os princípios que regem as sociedades por ações e o direito empresarial, o que também impede que sejam identificados novos elementos e práticas da atividade empresarial que sirvam de base para as mudanças legislativas que novas situações econômicas e sociais requerem.

Passados quase 33 anos da promulgação da Lei 6.404, verificase que a situação pouco mudou. A necessidade de, através da interpretação das normas positivas, atribuir significado e identificar situações recorrentes que possam constituir exemplos concretos de comportamentos e atitudes vedadas pela lei, em seus princípios gerais, constantes das normas abertas incluídas pelo legislador justamente com essa finalidade, ainda não foi suprida, o que aumenta a insegurança dos acionistas minoritários e dificulta o fortalecimento e desenvolvimento do mercado de capitais.

A jurisprudência em matéria de direito empresarial é escassa e, como concluíram os autores à época, ainda não se formaram linhas de jurisprudência capazes de definir posições claras quanto à interpretação dos conceitos e princípios gerais que regem as sociedades por ações. De fato, podemos concluir que a inexistência de linhas de jurisprudência consolidadas, a falta de especialização dos juízes nessa área do direito e a grande demora na solução das ações contribui para criar um círculo vicioso que afasta da prestação jurisdicional aqueles que deveriam dela se valer para garantia de seus direitos, contribuindo para manter essa situação.

Além disso, várias das decisões encontradas, muitas vezes sob a justificativa de que o Judiciário não pode interferir nas relações internas das companhias, acabam por permitir que situações injustas se perpetuem e que acionistas minoritários oprimidos e terceiros sejam prejudicados e não consigam uma solução eficaz para reparação de seus direitos o que também desacredita o papel do Judiciário na solução dos problemas envolvendo as sociedades por ações e o mercado de capitais. 
Osmar Brina Corrêa-Lima, em seu livro Sociedade Anônima ${ }^{156}$ relata um caso por ele patrocinado e que exemplifica os prejuízos que essa atuação tímida pode causar, até mesmo por desconhecimento dos princípios gerais que regem o direito empresarial e cada um dos tipos societários existentes, concluindo: "Como se vê, a decisão proferida neste caso comezinho e numa relação estritamente de Direito Privado colocou o seu prolator muito distante daquelas novas e relevantes funções que o Estado Moderno reserva aos magistrados."

A defesa de uma atuação eficaz e coerente do Judiciário na administração das sociedades por ações, não significa, de forma alguma, defender a irrestrita interferência judicial no mérito das decisões empresariais ou nas relações dos sócios ou ainda nas disposições por eles adotadas para regrar a administração, gestão e representação da sociedade desde que, obviamente, estejam em consonância com a legislação aplicável. A interferência judicial é válida e saudável para corrigir os desvios e a má utilização do instrumento em que se constituem as pessoas jurídicas, quando utilizadas para atingir interesses pessoais contrários aos da sociedade, para fraudar terceiros estranhos a ela ou ainda para oprimir os minoritários. Ao contrário, a segurança dos sócios de que os objetivos da sociedade não serão desviados para atender interesses pessoais e a existência de mecanismos eficazes que impeçam a ocorrência

156 Op. Cit., Pág. 482. "Também já tive oportunidade de apresentar uma dessas críticas construtivas. Tratava-se, no caso, de uma sociedade por cotas, de responsabilidade limitada: a sociedade compunha-se de três sócios, cada um detendo, exatamente, 1/3 do capital social. O objeto social era o tratamento dentário de deficientes mentais, com anestesia geral. Os cotistas A e B eram cirurgiões-dentistas. O C era o médico-anestesista responsável. O bem social mais valioso consistia num Convênio com o INSS. O contrato social não previa a sua alteração por maioria. Rezava, expressamente, que todos os atos de gerência deveriam ser assinados, sempre, por dois sócios em conjunto. O cotista A, sem respeitar o direito de preferência de C, vendeu todas as suas cotas (e o controle da sociedade) a B. A alteração contratual, sem a assinatura de $\mathrm{C}$, veio a ser arquivada na Junta Comercial. Consequentemente, B passou a assinar sozinho atos de gestão, embora persistisse a cláusula contratual exigindo a prática de atos de gerência sempre por dois sócios, em conjunto. Como preparativo para a ação anulatória da alteração contratual, C ajuizou medida cautelar inominada, na qual requereu liminar, com o objetivo de impedir que o cotista B continuasse a praticar atos de gerência isoladamente. O Juiz de Direito da $19^{\mathrm{a}}$ Vara Cível de Belo Horizonte não apenas indeferiu a liminar, como também a própria petição inicial da medida cautelar, que considerou inepta. O raciocínio do magistrado, implícito na decisão e verbalizado para um dos advogados da causa, baseava-se no tabu contra a intervenção do Poder Judiciário na intimidade das empresas. Consta de seu despacho a seguinte frase textual, intrigante e significativa: "Ademais, busca-se obrigar os Requeridos a cumprirem o contrato social, o que não depende de providência judicial, mas decorre de lei [...]". Encorajado pela timidez e titubeação judicial, o réu B acabou por fazer "justiça" com as próprias mãos. Despojou a sociedade de todos os seus bens materiais, transferindo-os para uma outra sede. Nesta, reativou antiga sociedade, com o mesmo nome da primeira, mas com contrato social arquivado no Cartório de Registro Civil das Pessoas Jurídicas, e que achava-se dissolvida de fato e com baixa no CGC, no Ministério da Fazenda. Com influência política, B conseguiu transferir para esta outra sociedade a titularidade do Convênio com o INSS. Além disso, alterou novamente, e unilateralmente, sem a assinatura de $\mathrm{C}$, o contrato de sua sociedade com este. Em suma, promoveu verdadeira dissolução, liquidação e extinção de fato. (Proc. n. 02491771520-3, 19ª Vara Cível de Belo Horizonte)." 
desses desvios, com a punição efetiva daqueles que se utilizarem da sociedade para atingir objetivos pessoais, contrários aos da sociedade, oferece garantia àqueles que pretendem investir no mercado acionário ou iniciar um novo empreendimento, fortalecendo a confiança nas instituições e revigorando a economia e o mercado de capitais.

Um exemplo de instituto criado pela jurisprudência que hoje se encontra positivado e que contribui para a segurança dos sócios e de terceiros, na correta utilização das sociedades para realização de seus fins, é o da desconsideração da personalidade jurídica ${ }^{157}$. A possibilidade de constituição de um ente com personalidade jurídica própria e prazo de existência indeterminado, capaz de assumir direitos e obrigações autônomos em relação a seus sócios os quais, ao mesmo tempo, tinham sua responsabilidade limitada aos valores aportados na sociedade, foi um dos principais fatores que contribuíram para o desenvolvimento e utilização das sociedades por ações para captação de recursos a um custo menor, realização de empreendimentos comerciais, especialmente de grande porte, e geração de riquezas.

O abuso dessas garantias legais, o desvio de finalidade e a intenção de prejudicar terceiros, escondendo-se atrás da pessoa jurídica, ressaltou a necessidade de se criarem exceções à regra da separação patrimonial e limitação de responsabilidades.

$\mathrm{O}$ acerto das medidas tomadas pelos tribunais, ao desconsiderar a personalidade jurídica das sociedades e responsabilizar diretamente o sócio que dela se utilizou de maneira fraudulenta e contrária aos objetivos para os quais foi constituída, e que motivam a proteção de sua personalidade autônoma, orientou o legislador a criar regra geral para desconsideração da personalidade jurídica de aplicação a todas as pessoas jurídicas, que tem por objetivo justamente proteger e fortalecer o instituto das

\footnotetext{
${ }^{157}$ A desconsideração da personalidade jurídica é um instrumento eficiente para coibir desvios e abusos dos acionistas através da sociedade. No entanto, a utilização desse instituto deve obedecer aos parâmetros de conduta estabelecidos na legislação especial (o Código de Defesa do Consumidor e no Código Tributário Nacional, por exemplo, possuem regras específicas que tratam da desconsideração da personalidade jurídica em determinadas situações) e no art. 50 do Código Civil, garantindo-se ainda que sejam observados os princípios de ampla defesa e do contraditório e não de forma automática (como vem ocorrendo na esfera da Justiça do Trabalho), como instrumento de pressão para agilizar o recebimento de valores executados, sob pena de se contrariar princípios básicos de Direito Societário e a segurança das relações jurídicas de qualquer operação praticada por seus sócios.
} 
pessoas jurídicas e sua adequada utilização, nos termos do artigo 50 do atual Código Civil.

Outros países reconheceram a necessidade de utilização de institutos semelhantes e desenvolveram mecanismos que permitem a intervenção judicial no âmbito interno das sociedades, em situações extremas, com o mesmo objetivo de preservar os interesses dos sócios, da sociedade e, indiretamente, os interesses externos a ela, tais como dos trabalhadores, fornecedores e consumidores que com ela atuam ou dependem e que são prejudicados pela má gestão ou desvios de finalidades dos controladores e/ou administradores.

O Código Civil Italiano prevê, no artigo 2409, a intervenção judicial nas sociedades, no caso de existência de grave irregularidade na atuação dos administradores, podendo o juiz, até mesmo, destituir os administradores e nomear um administrador judicial. A necessidade de intervenção na administração da sociedade tem fundamento não apenas na tutela dos interesses dos demais sócios, mas também dos interesses gerais “...conexos à correta administração da sociedade”, conforme trecho da decisão proferida pelo Tribunal de Milão, de 11.07.1995, reproduzido por Bartolomeo Quatraro e Emilio Tosi ${ }^{158}$ : "O controle judiciário objetiva diretamente a tutela não apenas da minoria societária (que pode também não existir, como no caso de sociedade pertencente substancialmente a um único sócio) mas do interesse geral conexo à correta administração da sociedade. Esta tutela não pode, por esta razão, ser negada, tanto no caso em que os sócios não têm conhecimento da irregularidade cometida pelos órgãos por eles nomeados, quanto, com maior razão, quando dela têm perfeito conhecimento, tornando-se participantes, porque também neste caso o interesse geral deve evidentemente prevalecer sobre aqueles dos sócios singularmente considerados. $\mathrm{O}$ Ministério Público é, na realidade, legitimado (mesmo no caso da sociedade pertencente

${ }^{158}$ Il Controllo Giudiziario ..., pág. 165: "Il controllo giudiziario è diretto a tutela non solo delle minoranze sociali (che possono anche non esservi, como nel caso di società sostanzialmente appartenente ad un unico socio) ma dell'interesse generale connesso alla corretta amministrazione della società. Questa tutela non può quindi essere esclusa tanto nel caso in cui i soci non si accorgano delle irregularità commesse dagli organi da loro nominati, quanto, a maggior ragione, allorché ne siano perfettamente consapevoli, divenendone partecipi, perché anche in questi casi l'interesse generale deve evidentemente prevalere su quello dei singoli soci. Il Pubblico Ministero è, infatti, legittimato (anche nel caso di società appartenente sostanzialmente ad unico socio) a proporre la denunzia ex art. 2409 c.c., non solo a tutela dell'interesse dei soci di minoranza dei creditori, ma anche a tutela dell'interesse generale a una ordinata e regolare amministrazione delle società di capitali." 
substancialmente a um único sócio) a propor a denúncia prevista no art. 2409 do Código Civil, não apenas para tutela do interesse dos sócios minoritários e dos credores, mas também para tutela do interesse geral a uma correta e regular administração das sociedades de capital."

Prosseguem os autores ainda, reproduzindo a posição de Vincenzo Vitrò, que defende a irrelevância da individualização dos interesses tutelados para intervenção judicial nas sociedades e que entende que “...a posição mais correta e conforme ao espírito e à estrutura do procedimento em discussão é aquela que nega (...) a funcionalização dos deveres dos órgãos de gestão à consecução dos interesses externos à sociedade. Não originam, portanto, os deveres dos administradores e dos fiscais correlatos aos interesses públicos: interesses de financiamento público, da economia pública, dos consumidores, dos trabalhadores, da tutela do meio ambiente, etc. Os procedimentos previstos no art. 2409 não têm por finalidade a tutela de um interesse público ${ }^{159, "}$. E concluem, resumindo o posicionamento de Vitrò: “...parece correto afirmar que aquilo que releva aos fins do procedimento de controle judiciário nos termos do art. 2409 do Código Civil, não é tanto a noção, a classificação e a individualização dos interesses tutelados pelo ordenamento jurídico do que a violação dos deveres por parte dos órgãos administrativos da sociedade, materializada em "grave irregularidade" 160 .

Também na Argentina existe instituto semelhante de intervenção judicial de sociedades, regulado nos artigos 1683 e 1684 do Código Civil, através do qual os sócios de uma sociedade podem revogar judicialmente o mandato do administrador quando este se nega a aceitar as causas de sua remoção, podendo o juiz, inclusive, em caso de perigo, nomear administrador judicial provisório, que pode ser

\footnotetext{
${ }^{159}$ VITRÒ, Vincenzo, Controllo Giudiziario e Provedimenti Cautelari nelle Società di Capitali, apud, QUATRARO, Bartolomeo e TOSI, Emilio. Il Controllo Giudiziario..., pág. 176: “...la posizione più corretta e conforme allo spirito e alla struttura del procedimento in discussione è quella che nega (...) la funzionalizzazione dei doveri degli organi gestori al perseguimento di interessi esterni alla società. Non sussistono pertanto doveri degli amministratori e dei sindaci correlati ad interessi publici: interessi delle finanzie pubbliche, dell'economia pubblica, dei consumatori, dei lavoratori, della tutela dell'ambiente, ecc. I provvedimenti ex art. 2409 non sono finalizzati alla tutela di un interesse pubblico."

${ }^{160}$ Il Controllo Giudiziario..., pág. 177: “...sebrerebbe corretto doversi affermare che ciò che rileva ai fini del procedimento di controllo giudiziario ex art. 2409 c.c. sia non tanto la nozione, la classificazione e l'individuazione degli interessi tutelati dall'ordinamento giuridico quanto la violazione di doveri da parte degli organi amministrativi della società concretantesi nelle 'gravi irregolarità’”.
} 
sócio ou não ${ }^{161}$. Segundo Osvaldo Walter Coll ${ }^{51}$, “... o fundamento intrínseco da possibilidade de intromissão do Estado na vida da sociedade fica reduzido à negativa do administrador de retirar-se da mesma uma vez operada sua remoção e à existência de perigo que justifique a medida."

Esse instituto tem origem pretoriana como relata o autor ${ }^{162}$ : "Resulta evidente que no espírito do legislador existia uma certa reserva a intrometer-se na vida da sociedade, regulando este instituto de modo residual sem outorgar-lhe autonomia operativa, como logo o fez a Lei 19.550, vários Códigos Processuais provinciais e o Código Processual Civil e Comercial da Nação. Rompendo esse esquema restritivo, em 1948 a Câmara de Comércio da Capital Federal autorizou a intervenção judicial de uma sociedade a fim de organizar a vida interna da mesma e conseguir um pronunciamento da assembléia que solicitavam os reclamantes. Posteriormente, em 1958, a Corte Suprema de Justiça da Nação profere novo julgamento que avança sobre os pressupostos do caso 'Uman', já que admite a intervenção judicial de uma sociedade, diante das irregularidades manifestas na constituição da assembléia, e que põe em julgamento o funcionamento da mesma."

O objetivo do legislador com a aplicação do instituto da intervenção judicial na Argentina é proteger os interesses da sociedade e dos sócios de

${ }^{161}$ Intervención Judicial de Sociedades. Buenos Aires: Lexis Nexis, 2005, pág. 9: "La regulación del instituto de la intervención judicial, se encuentra em los arts. 1683 y 1684, CCiv., que reconocen a los sócios de la sociedad civil la posibilidad de revocar al mandatario por vía judicial su mandato, cuando este se negar a aceptar las causas de revocación. Asimismo, en caso de peligro, se permite que el juez decrete la remoción y nombre um administrador provisório, que puede ser socio ou no. Como se advertirá, el fundamento intrínseco de la posibilidad de la intromisión del Estado em la vida de la sociedad queda reducido a la negativa del administrador a retirarse de la misma una vez operada su remoción, y la existência de peligro que justifique la medida."

${ }^{162}$ Intervención..., pág. 9 e 10: "Resulta evidente que em el espíritu del legislador existia una cierta reserva a entrometerse en la vida de la sociedad, regulando este instituto de modo residual sin otorgarle autonomía operativa, como luego lo hicieron la ley 19.550, varios Códigos Procesales provinciales e incluso el Código Procesal Civil y Comercial de la Nación. Rompiendo este esquema restrictivo, en 1948 la Cámara de Comércio de la Capital Federal autorizó la intervención judicial de uma sociedad a fin de ordenar la vida interna de la misma y conseguir um pronunciamiento de la asamblea que solicitaban los reclamantes. Posteriormente, en 1958, la Corte Suprema de Justicia de la Nación dicta um nuevo fallo que avanza sobre los supuestos del caso 'Uman', ya que admite la intervención judicial de una sociedad ante las irregularidades manifiestas en la constitución de la asamblea, y que ponde em tela de juicio el funcionamiento de la misma." Notas do autor: os casos por ele citados são, respectivamente, os julgados pela Cámara de Comércio da Capital Federal, em 26.11.1948, "Uman, Simón v. Seglin, Gregório, LL 53194 e pela Corte Suprema de Justicia de la Nación em 25.04.1958, 'Feune de Colombi, Diego y otros v. La Esmeralda Capitalización S.A.', LL 90-392." 
forma conjunta e simultânea ${ }^{163}$ como conclui o autor: "A doutrina, por seu lado, reconheceu que esta figura deve estar dirigida a proteger tanto o interesse dos sócios como o interesse da sociedade. Dos três elementos que mencionamos como possíveis objetos da tutela judicial, este é talvez o mais claro e contundente, já que vem a justificar de modo integral a alteração que, no regime da administração, provoca a intervenção judicial. Evidentemente, deve se proteger não apenas o interesse da sociedade mas também dos sócios, e ainda que colocado deste modo pareça óbvio, quando se começa a analisar o caso concreto aparecem zonas cinzentas. Assim, então, a jurisprudência tem reconhecido, por exemplo, a possibilidade de designar um inspetor administrador se por aplicação das maiorias se reduziu o número de integrantes de uma diretoria a fim de evitar o exercício do voto cumulativo que prevê o art. 263 da lei de sociedades, com o qual se alterava o regime de administração existente anteriormente. Nem sempre é tão simples delimitar onde termina o interesse dos sócios e começa o da sociedade. Resta claro que ao proteger a sociedade estão se protegendo os interesses dos sócios. Este parágrafo supõe que ao se falar em interesse da sociedade e dos sócios se percorre um caminho no qual alguns sócios se beneficiam em detrimento de outros, como ocorre no caso jurisprudencial citado. No nosso entendimento, o tema se ordena a partir da aplicação da noção de 'bem comum'. De fato, a função da intervenção judicial ou qualquer outra medida cautelar prevista por lei, se verá justificada quando existirem sócios que permaneçam marginalizados dos direitos que lhes correspondem, por ações exercidas por outros sócios, valendo-se da estrutura societária. Isso não apenas prejudica o sócio, como a sociedade mesma que não cumpre o fim para o qual foi criada e que é de todos os sócios participarem dos ganhos e suportarem as perdas. Repare-se que, em conseqüência, a proteção do interesse do sócio e da sociedade deve significar necessariamente uma eqüitativa e sadia participação de todos em função das participações obtidas e, sobretudo, a inexistência de abuso daqueles que ostentam maiorias societárias sobre as minorias. Este tem sido, em geral, o espírito da jurisprudência que tem protegido a concepção de proteção do sócio e da sociedade. $\mathrm{O}$ 'bem comum' não é a soma de todos os bens individuais, senão um interesse superior que engloba os indivíduos e todo seu conjunto de modo harmonioso e participativo."

${ }^{163}$ COLL, Osvaldo Walter. Intervención..., págs. 23 e 24. 
O único dispositivo da Lei das S.A. que prevê de forma expressa a substituição do Judiciário na tomada de decisões da companhia, consta do parágrafo $2^{\circ}$ do artigo 129, prevista especificamente para os casos em que ocorrer empate nas deliberações tomadas em duas Assembléias Gerais, a segunda realizada, no mínimo, 60 dias após a primeira Assembléia, se o Estatuto Social não contiver procedimento de arbitragem ou norma diversa e se os acionistas não concordarem em submeter o impasse para solução de terceiro ${ }^{164}$.

Paulo Salvador Frontini, em artigo analisando acórdão proferido pela $3^{\text {a }}$ Câmara de Direito Privado do Tribunal de Justiça do Estado de São Paulo ${ }^{165}$, comentou a aplicação dessa regra, concluindo que “...No caso de empate em deliberação societária, a peculiariedade da intervenção do Poder Judiciário está na circunstância de que a autoridade judicial não vai decidir sobre legalidade ou ilegalidade da questão posta. Esse aspecto obviamente será apreciado num primeiro momento, mas o cerne da intervenção judicial dirá respeito à conveniência e oportunidade da matéria a ser objeto da deliberação, no interesse da companhia, como literalmente diz a lei."

No entanto, aprofundando a análise quanto à natureza do procedimento judicial e a estranheza causada a doutrinadores pela solução legal, principalmente em razão dos prejuízos que poderiam ser causados à companhia, no caso de não ser possível alterar posteriormente a decisão judicial transitada em julgado, caso revele necessário para atender alterações nas condições de mercado ou caso a decisão se revele não ser a economica ou estrategicamente mais adequada, conclui o autor a ação a ser ajuizada terá natureza de jurisdição voluntária ${ }^{166}$, em que o Judiciário, ao invés de ser chamado a decidir "...o mérito de questões que não se cingem à legalidade ou

${ }^{164} \mathrm{O}$ Código Civil prevê no art. 1.010, que no caso de empate nas deliberações tomadas pelos sócios de uma sociedade simples, e nas sociedades limitadas, por remissão expressa do art. 1072, alterar-se-á o critério para apuração dos votos, aprovando-se a decisão sufragada por maior número de sócios. Se o impasse continuar, a decisão caberá ao Judiciário. "Art. 1.010. Quando, por lei ou pelo contrato social, competir aos sócios decidir sobre os negócios da sociedade, as deliberações serão tomadas por maioria de votos, contados segundo o valor das quotas de cada um. \$ 10 Para formação da maioria absoluta são necessários votos correspondentes a mais de metade do capital. \$ $2^{\mathbf{0}}$ Prevalece a decisão sufragada por maior número de sócios no caso de empate, e, se este persistir, decidirá o juiz." (Grifo nosso).

${ }^{165}$ Sociedade por Quotas. Revista de Direito Mercantil, Industrial, Econômico e Financeiro, vol. 114. São Paulo: Revista dos Tribunais, abril-junho 1999, pág. 165 e seguintes. Não obstante o acórdão versar sobre controvérsia envolvendo uma sociedade por quotas de responsabilidade limitada, o Professor Paulo Salvador Frontini comentou o $\S 2^{\circ}$ do art. 129, à época aplicável às limitadas, por determinação do art. 18, do Decreto $\mathrm{n}^{\mathrm{o}}$ 3.708, de 1919, hoje revogado pelo atual Código Civil. Atualmente, na ocorrência de empate das deliberações das limitadas, será aplicado o art. 1.010 do Código Civil.

${ }^{166} \mathrm{Na}$ forma dos arts. 1.103 e seguintes do Código de Processo Civil. 
ilegalidade”, promove verdadeira “...administração pública de direitos privados, matéria que nem é contenciosa nem caracteriza a jurisdição em sua plenitude...”, a exemplo do que ocorre nas ações para suprimento de outorga uxória, em que o juiz poderá suprir, ou não, o consentimento negado, para realização de um negócio jurídico privado ${ }^{167}$ analisando as motivações das partes envolvidas.

Desta forma, conforme prevê o artigo 1.111 do Código de Processo Civil, a decisão judicial não acarretará um "engessamento" da sociedade, na medida em que não produz os efeitos da coisa julgada, podendo ser modificada, sem prejuízo dos efeitos já produzidos, se ocorrerem circunstâncias supervenientes. Caberá aos administradores da companhia ajuizar a ação, requerendo o provimento judicial para por fim ao impasse e permitir que a sociedade continue suas atividades.

O Código Civil prevê, no art. $49^{168}$, de aplicação a todas as pessoas jurídicas, a administração da pessoa jurídica pelo Judiciário, se os administradores vierem a faltar, podendo qualquer interessado requerer essa providência. No caso das sociedades por ações, podemos vislumbrar as seguintes hipóteses em que todos os administradores da companhia fiquem concomitantemente impedidos de exercer suas funções:

a) - se os administradores impedidos de exercer suas funções, não forem os únicos acionistas (isto é, se os acionistas ainda puderem exercer direito de voto), qualquer acionista remanescente, em caráter excepcional e desde que comprovado o impedimento dos administradores, deverá convocar Assembléia Geral Extraordinária urgente para eleição dos novos administradores da companhia, não se aplicando esse artigo, a menos que haja demora na convocação da Assembléia; ou

b) - se os administradores impedidos forem os únicos acionistas da companhia e também estiverem impedidos de exercer suas funções como sócios, não podendo eleger novos administradores, qualquer interessado poderá requerer judicialmente

\footnotetext{
${ }^{167}$ FRONTINI, Paulo Salvador. Sociedade..., pág. 167.

168 “Art. 49. Se a administração da pessoa jurídica vier a faltar, o juiz, a requerimento de qualquer interessado, nomear-lhe-á administrador provisório."
} 
a nomeação de um administrador provisório, até que seja possível realizar nova Assembléia Geral, composta pelos acionistas, se cessar o impedimento, seus herdeiros, sucessores ou curadores, que elegerão os novos administradores da companhia $^{169}$.

Nesta última hipótese, se o Estatuto Social contiver regra que impeça a transmissão das ações aos herdeiros ou sucessores do acionista, e não restar mais um único acionista que possa adquirir as ações dos demais, para posteriormente recompor o quadro social ${ }^{170}$, o Judiciário também deverá enfrentar o problema da validade das cláusulas que impedem a transmissão das ações a herdeiros ou sucessores dos acionistas. Em um primeiro momento, essa regra confere um caráter altamente personalista à companhia, que está intrinsicamente vinculada à figura de seus sócios. No entanto, considerando que todos os sócios que impuseram essa condição faleceram, desaparece o caráter personalista da companhia e o interesse dos sócios tutelados por essa disposição, que poderiam se opor a alterá-la. Assim, havendo interesse de pelo menos parte dos herdeiros e sucessores dos acionistas em manter a sociedade funcionando, entendemos possível que o Judiciário permita a realização de Assembléia Geral dos herdeiros e sucessores dos acionistas falecidos, para que estes reformem o Estatuto Social e nomeiem novos administradores.

Pelos argumentos apresentados anteriormente, com base nos comentários de Paulo Salvador Frontini, entendemos que a aplicação dos artigos 49 e 1.010 do Código Civil, em consonância com o $§ 2^{\circ}$ do artigo 129 da Lei das S.A., também dar-se-á por procedimento de jurisdição voluntária, na forma dos artigos 1.103 e seguintes do Código de Processo Civil.

No Brasil, a jurisprudência não tem enfrentado os problemas decorrentes da aplicação prática e construção de linhas de interpretação dos princípios gerais que regem as sociedades por ações, principalmente em face da nova realidade de formação dos Grupos econômicos, de fato e de direito, e levando em consideração os

${ }^{169}$ Esse risco é real nos casos de companhias fechadas constituída por apenas 2 sócios, que são também os 2 únicos Diretores da companhia, se estes ficarem impedidos ou vierem a falecer ao mesmo tempo.

${ }^{170}$ Sob pena de dissolução da sociedade, de pleno direito, nos termos do item "d" do art. 206 da Lei 6.404 . 
fatos novos decorrentes do desenvolvimento do mercado de capitais e da globalização da economia. ${ }^{171}$

Exemplo desse avanço do Poder Executivo sobre o papel que deveria ser exercido pelo Judiciário pode ser verificado pelo exame da Lei 6.385/76, que criou a Comissão de Valores Mobiliários e definiu suas competências, dentre as quais, a de impor aos administradores e acionistas das sociedades por ações de capital aberto, penalidades pela infração das disposições contidas na Lei das S.A., conforme dispõe o artigo 11 dessa Lei, incluindo a suspensão do exercício do cargo de administrador ou de conselheiro fiscal, inabilitação temporária, advertência ou multa.

Como consequiência, verifica-se hoje que a jurisprudência administrativa da CVM, que exerce função fiscalizadora e reguladora das S.A. que atuam no mercado de valores mobiliários é muito mais ampla e capaz de definir os entendimentos desse órgão, com relação a diversos assuntos relacionados a esses temas, produzindo material de análise e pesquisa superior à jurisprudência de nossos tribunais. Conforme exposto anteriormente, a criação de instituições administrativas com função investigativa e punitiva, é uma das formas de que o Estado dispõe para conferir eficácia e fortalecer o sistema jurídico, mediante a fiscalização e aplicação da lei e interpretação dos termos incompletos que estão nela contidos.

Essa situação pode ser justificada pelo fato de a própria CVM, no exercício de sua função fiscalizadora, estão legitimidos a iniciar procedimento administrativo para apurar uma situação potencialmente prejudicial aos minoritários de uma companhia ou ao mercado, independentemente de provocação de uma das

\footnotetext{
${ }^{171}$ Como observa BASTOS, Aurélio Wander Bastos, em $O$ Poder Judiciário...., pág. 30: analisando a jurisprudência produzida a partir da promulgação da atual Lei das S.A.: "Este é o grande drama do Judiciário moderno: a sua capacidade adaptativa e as suas condições de modernização estão contidas e sufocadas pelas características liberais de sua estrutura burocrática, principalmente, representada pela complexidade processual, pela centralização estrutural, pela dependência organizacional e pelas tradições vinculares de sua Jurisprudência. Basicamente ele é impedido de atender a estes condicionantes devido aos seguintes fatores: baixa flexibilidade para acompanhar a mudança social e restrita autonomia decisória para interferir em conflitos complexos. Desta forma, como podemos observar, o Poder Judiciário no Brasil está sofrendo uma compressão historicamente dilacerante: se de um lado ele não consegue se firmar como um poder autenticamente legítimo, com a elasticidade e a flexibilidade necessárias para resolver interesses de uma sociedade em intenso processo de modernização, de outro lado, está circunscrito na sua capacidade adaptativa pelo avanço judicial das competências executivas."
} 
partes $^{172}$, o que se apresenta como uma vantgem na complementação e interpretação das normas incompletas, em relação ao Judiciário, que atua somente mediante provocação e após ocorrência de prejuízos para as partes envolvidas.

A conclusão que a análise desses fatos leva é que, no que se refere ao desenvolvimento e aplicação do Direito Societário, especialmente nas questões envolvendo as sociedades por ações, o Judiciário não vem desempenhando o papel que lhe cabe e que é fundamental para interpretação de seus princípios legais e adaptação da legislação aos fatos sociais e econômicos e às práticas de mercado, para as adaptações legislativas necessárias para acompanhar essa evolução. Nelson Laks Eizirik ${ }^{173}$ chamou a atenção para este fato, ao analisar a atual Lei das S.A. em comparação com a anterior e assim concluiu: "No caso brasileiro, por outro lado, já notamos inicialmente que as principais inovações da Lei de Sociedades Anônimas e da Lei que criou a Comissão de Valores Mobiliários (Lei $\mathrm{n}^{\mathrm{0}}$ 6.385, de 7/12/76) - relacionadas mais diretamente com a regulação das companhias abertas e intermediários financeiros e com a proteção aos acionistas pouco têm a ver com a Jurisprudência. Com efeito, praticamente não há dispositivos em tais leis que se tenham originado de decisões dos tribunais. Isto se deve a duas razões: em primeiro lugar, pela ausência, conforme antes assinalamos, de decisões judiciais efetivamente inovadoras, e em segundo lugar, pela natureza prospectiva de muitas das normas das Leis $n^{\circ}$ s 6.404 e $n^{0} 6.385$, com inspiração mais direta no Direito Comparado. É tipicamente o caso das normas referentes ao disclosure a ser prestado pelas companhias abertas, das normas de repressão ao insider trading e das normas sobre grupos de sociedades e sobre oferta pública para aquisição de controle

${ }^{172}$ PRADO, Viviane Muller. Reflexões sobre Enforcement ..., reportando-se à pesquisa realizada pela Escola de Direito da Fundação Getúlio Vargas, das decisões da CVM tomadas no período de janeiro de 2000 a junho de 2006, conclui à pág.126: "Em matéria de societário, foram encontrados uma infinidade de temas, que o trabalho classificou em cinco itens, quais sejam: transparência e dever de informar; estrutura de propriedade (controle societário) e suas modificações; irregularidades no exercício da atividade, isto é, em relação ao poder de decisão dos acionistas controladores e à atuação dos administradores; direito dos acionistas minoritários; e insider trading envolvendo agentes internos à sociedade. (...) Constata-se que a irregularidade no exercício da atividade, no qual estão os temas de abuso do poder de controle e deveres societários dos administradores, apareceu de maneira mais elevada, se comparada com os resultados das pesquisas de jurisprudência do Poder Judiciário. Uma das possíveis razões para isso está na legitimidade para iniciar o procedimento administrativo. Na pesquisa da CVM, constatou-se que a irregularidade investigada foi detectada a partir da atividade fiscalizadora de algumas das superintendências da CVM ou se a autarquia teve conhecimento da infração em decorrência de atos de terceiros. Em 61 dos casos analisados (57,5\% do total), a CVM teve conhecimento da irregularidade objeto do processo administrativo a partir de iniciativas próprias. Na comparação com o Poder Judiciário, outra diferença que chama a nossa atenção quanto aos padrões da decisão é a análise mais apurada dos fatos na CVM e o maior cuidado na fundamentação das razões de decidir."

${ }^{173}$ O Poder Judiciário...., pág. 51. 
de companhia aberta, apenas para citarmos alguns exemplos. Assim, há pouca possibilidade de comparações entre a Jurisprudência e a nova Lei das Sociedades Anônimas, na medida em que esta Lei regula, de certa forma, para o futuro. A análise que cabe, então, é a do papel que deverá ser desempenhado pelos tribunais na regulação do mercado de capitais, em face de algumas peculiaridades da Lei."

Em linhas gerais, a análise do Judiciário de algum ato praticado ou decisão tomada por administrador da companhia ou por seus acionistas, deve partir dos princípios que regem o direito empresarial em geral e esse tipo de sociedade em particular. Como já mencionado, a evolução desse tipo societário atribuiu poderes aos acionistas titulares da maioria do capital social para determinar os rumos da companhia e dirigir seus negócios sociais, ao mesmo tempo em que propiciou a separação de responsabilidades e do patrimônio dos acionistas e administradores em relação à companhia. Assim, os controladores e administradores de uma companhia são detentores dos poderes para decidir sobre a utilização dos recursos e prática de atos pela companhia, a qual assumirá as consequiências e responsabilidades desses atos, desde que estes tenham sido praticados e/ou tomados de acordo com as determinações legais e estatutárias e no interesse da companhia.

Os acionistas, em Assembléia Geral que é a instância final, na companhia, para decidir o mérito das questões que envolvem sua administração, e os administradores detém o poder de tomar decisões baseadas em critérios de conveniência e oportunidade. Ainda que essas decisões causem prejuízos, elas devem ser observadas se tomadas de boa-fé e tiverem sido tomadas as precauções que o dever de diligência determina. O Judiciário, nesses casos, somente pode examinar a legalidade das decisões em relação a esses aspectos, mas não quanto ao mérito. É desta forma que a lei protege os acionistas e administradores em relação às conseqüências dos atos por eles praticados, decorrentes do exercício do poder discricionário de administração, semelhante ao conferido aos agentes da administração pública para a prática de determinados atos. 
Eros $\mathrm{Grau}^{174}$, ao analisar a prática de atos discricionários por agentes públicos, conclui: “A discricionariedade, vimos, expressa-se na formulação de juízos de oportunidade, importando eleição entre indiferentes jurídicos, à margem, pois, da legalidade. Logo, no Estado de Direito, qualquer agente público somente deterá competência para a prática de atos discricionários - isto é, exercitando as margens de liberdade de atuação fora dos quadrantes da legalidade - quando norma jurídica válida a ele atribuir a formulação de juízos de oportunidade. Fora dessa hipótese, qualquer agente público estará jungido, subordinado à legalidade."

A discricionariedade no exercício de um poder, conferida por lei a um agente do poder público ou ao acionista controlador, é justamente a liberdade conferida a essa pessoa, de eleger, “...dentre alternativas igualmente justas ou entre indiferentes jurídicos - porque a decisão se fundamenta em critérios extrajurídicos (de oportunidade, econômicos, etc.) não incluídos na lei e remetidos ao juízo subjetivo da Administração..."

Hely Lopes Meirelles ${ }^{176}$ define poder discricionário como o poder conferido por lei à Administração, de forma explícita ou implícita, “...para a prática de atos administrativos com liberdade de escolha de sua conveniência, oportunidade e conteúdo." Esse poder discricionário conferido ao agente público caracteriza-se pela maior liberdade de ação para prática de um determinado ato. Por outro lado, a lei impõe, ao administrador, limites quanto à competência, à forma e à finalidade do ato. Assim, para que o ato praticado seja considerado em conformidade com a lei e, portanto lícito, o administrador deverá: (a) ter competência legal para praticar aquele ato; (b) obedecer à forma legal para a sua realização; e (c) o ato deverá ser praticado com o objetivo de atender a finalidade legal de todo ato administrativo, que é o interesse público ${ }^{177}$.

Os mesmos limites aplicados no campo do Direito Administrativo se impõem na análise da legitimidade dos atos praticados pelos

\footnotetext{
${ }^{174}$ O Direito Posto..., pág. 206.

${ }^{175}$ GRAU, Eros. O Direito Posto..., pág. 202.

176 Direito Administrativo Brasileiro. $18^{\mathrm{a}}$ edição, atualizada por Eurico de Andrade Azevedo, Délcio Balestero Aleixo e José Emmanuel Burle Filho. São Paulo: Malheiros, 1990, pág. 102.

${ }^{177}$ MEIRELLES, Hely Lopes. Direito Administrativo..., pág. 103.
} 
administradores e as decisões dos controladores de uma companhia. A ambos a lei atribui poder para tomar decisões, de acordo com seus conhecimentos técnicos, garantindo que atuem com discricionariedade na tomada de decisões. Nas sociedades por ações, o princípio majoritário determina que o controle da companhia seja exercido pelos acionistas detentores da maioria do capital social. A escolha, pelos acionistas, dos administradores encarregados de conduzir os negócios da sociedade, confere a essas pessoas o poder de determinar os rumos da sociedade, desde que: (a) observada a competência conferida por lei e pelo Estatuto aos órgãos societários; e (b) o ato praticado ou decisão tomada observem a forma legal ou estatutária para sua realização e tal ato ou decisão tenha sido tomada no interesse da companhia.

Além disso, os poderes discricionários atribuídos aos indivíduos que detém o poder de controle da companhia, não obstante expressarem interesses próprios do titular do poder, estão limitados por lei a interesses de terceiros que merecem proteção. Esses interesses de terceiros devem ser considerados e limitam o exercício do poder discricionário, ainda que privado, o qual pode ser analisado sob dois aspectos: (a) o interesse substancial que se reflete em um bem que depende dos efeitos do exercício do poder de controle; e (b) o interesse instrumental a que o poder seja exercido de acordo com determinado procedimento, com base em princípios que impõem ao sujeito titular do poder considerar esses interesses relevantes ${ }^{178}$.

\footnotetext{
${ }^{178}$ GAMBA, Cinzia. Diritto Societario..., pág. 98: "Mentre nel contesto amministrativistico il riferimento è all'azione preordinata alla realizzazione di un fine di carattere pubblico, nell'ambito dei rapporti privati ciò che rileva nel concetto di funzione e che caratterizza la discrezionalità del potere è il fatto che esso sia esercitato dal suo titolare per un interesse proprio dell'agente, o comunque non solo próprio, ma per un interesse oggettivo o di altri soggetti. (...) In questa prospettiva, lidea di funzione permette di definire come 'poteri privati' gli atti e i comportamenti che costituiscono l'esercizio di um potere discrezionale da parte di soggetti e che possono essere espressione di un interesse proprio del titolare del potere ma che sono pur sempre teleologicamente correlati ad interessi altrui, sui quali sono idonei ad incidere permettendone legittimamente la realizzazione o il sacrifício. L'emergere di un interesse altrui (l'interesse legittimo) nel raggio di azione del soggetto agente, dotato di potere discrezionale, viene a ridurre il margine di scelta a questi consentito. Gli impone infatti di tenere conto direttamente ed immediatamente anche di tale interesse, il quale funziona come vincolo intrínseco alla discrezionalità. I limiti al potere discrezionale permettono di riscostruire il contenuto della posizione soggettiva che si contrappone al potere privato, nella quale convivono due aspetti strettamente correlati ma pur sempre distinti: l'interesse sostanziale che tende verso um bene della vita, che è quello che dipende dagli effetti dell'esercizio del potere, e un interesse strumentale a che il potere stesso sia esercitato secondo certe modalità, ossia in base a principi di correttezza che impongano al soggetto titolare del potere di prendere doverosamente in considerazione l'interessi altrui."
} 
A análise quanto à validade dos de administração no âmbito das sociedades por ações, deve, então, se restringir a dois aspectos ${ }^{179}$ : o primeiro, com relação à validade da Assembléia Geral ou Reunião dos órgãos administrativos em que foi tomada a deliberação. Sob este aspecto, o juiz deverá verificar a existência de eventuais vícios de convocação, instalação, a regularidade dos quoruns de instalação e de aprovação das deliberações tomadas e o objeto das deliberações. A inobservância dos requisitos formais previstos na legislação ou no Estatuto Social poderá levar à ineficácia e anulação das deliberações, que não surtirão quaisquer efeitos perante terceiros ou à própria companhia e seus acionistas.

O outro ascecto que deverá ser analisado refere-se aos vícios de vontade que poderão determinar a anulação ou nulidade das deliberações, caso o voto viciado tenha sido determinante para a aprovação da deliberação. Nessas hipóteses estão abrangidas, além do erro, dolo, coação ou simulação ${ }^{180}$ que tenham ocorrido ou influenciado um acionista, a ocorrência de conflito de interesses, abuso do direito ou abuso do poder de controle por parte do acionista que proferiu voto determinante para a formação da maioria.

Tendo sido eles observados ambos os aspectos referidos acima, a companhia e seus acionistas estão sujeitos aos riscos da atividade empresarial. Os

${ }^{179}$ PENTEADO, Mauro Rodrigues. Aumentos..., pág 280.

180 ASCARELLI, Tullio. Vícios das Deliberações...., em Problemas..., pág. 551, notas 1178 a 1180 , pondera, com relação às hipóteses de existência de erro, dolo, fraude ou simulação que podem viciar as deliberações: "A rigor, o erro e o dolo podem, parece-me, tão-somente erespeitar ao 'voto', embora, em alguns casos, possam concernir a 'todos' os votos da deliberação. Cf. Donati, op. cit, p. 252. Quando, entretanto, pela sua própria natureza, o erro ou o dolo viciem todos os votos (como, por exemplo, quando decorram de falsas declarações dos diretores acerca das causas das perdas da sociedade, sendo, por isso, viciados todos os votos que aprovaram a exoneração dos diretores da responsabilidade que lhes incumbia, à vista da efetiva causa das perdas; cf. art. 101 [atual $\S 3^{\circ}$ do art. 134], poderá já a sociedade impugnar a deliberação; poderá impugná-la qualquer acionista, sendo, então, inútil examinar qual a importância dos votos do acionista-autor na formação da maioria, pois que todos os votos foram viciados." "Quanto à hipótese de 'fraude', cumpre distinguir entre a fraude à lei e a fraude contra terceiros. A hipótese de 'fraude' à lei cabe já no caso geral, de 'violação da lei' (...) o caso de fraude contra terceiros é, por seu turno, bem diversos dos de erro e dolo. (...) A rigor, portanto, esta hipótese cabe no âmbito do direito comum e não na disciplina dos vícios da formação da vontade social encarada no art. 286 da Lei no 6.404 , de 15 de dezembro de 1976 (art. 156 no direito anterior); entretanto, à vista da redação do art. 286, mister é, talvez, concluir, caber, ela, no art. 286." “O caso da 'simulação' pode, talvez, dar lugar a um exame particular. Com efeito, é preciso lembrar que a deliberação assemblear constitui um ato decorrente, sim, de pluralidade de manifestações de vontade, mas de uma pluralidade de manifestações de vontade que se fundem naquela que, juridicamente, constitui 'a' manifestação de vontade de 'uma só parte'; por seu turno também o voto constitui um negócio unilateral. Parece, por isso, difícil encarar a hipótese de simulação (...) Mais próximo da 'simulação' é o caso de uma deliberação assemblear que determine, por exemplo, o objeto social, comprometendo-se porém, os sócios, para que a sociedade, na realidade, desenvolva uma atividade diferente da determinada no seu objeto." 
resultados da decisão, ainda que bem fundamentada, e que se acredite conveniente e oportuna à companhia no momento em que foi tomada, dependerão de diversos fatores externos, sob os quais os acionistas e administradores não têm controle e não poderão ser responsabilizados se tiverem empregado. O emprego de cuidado e diligência que todo homem ativo e probo costuma empregar na administração de seus próprios negócios é o padrão de conduta exigido pela lei para

A disciplina que trata dos atos empresariais privilegia a segurança jurídica dos terceiros que contratam com a sociedade e a estabilidade dos atos por ela praticados, restringindo as hipóteses de nulidade absoluta das deliberações assembleares apenas nas hipóteses de impossibilidade ou ilicitude do objeto do ato praticado; nas demais hipóteses de inobservância de alguma determinação legal relativa à regularidade do procedimento para a deliberação, competência ou ilegitimidade de voto de algum dos acionistas (por conflito de interesses, abuso do direito de voto ou abuso do poder de controle), a lei possibilita a anulação da deliberação, em prazo inferior ao vigente para anulação dos demais tipos de negócios jurídicos ${ }^{181}$.

Os atos societários estão sujeitos a um regime especial de anulabilidades, em razão da necessidade de preservação dos interesses dos terceiros envolvidos na existência da sociedade e do grande número de pessoas afetadas pelos atos por ela praticados. Esse regime especial, no entanto, não afasta totalmente o regime de nulidade dos atos jurídicos, na forma dos artigos 166 e 184 do Código Civil, conforme conclusão de Erasmo Valladão Azevedo e Novaes França ${ }^{182}$ : "Vários outros dispositivos da Lei ${ }^{\circ}$ 6.404/76, porém, como se disse, levam à mesma conclusão, não havendo como afastar, portanto, a aplicação do regime comum relativo à nulidade dos atos jurídicos, previsto nos arts. 145 e 146 do Código Civil [atuais 166 e 167], às deliberações que estabeleçam disciplina contraveniente àquela determinada nos mencionados dispositivos. Vale dizer, a nulidade de tais deliberações, se não detectada oportunamente pelo Registro do Comércio (arts. 97 e 135, § 2º da Lei $n^{\circ}$ 6.404), poderá ser alegada por qualquer interessado, ou pelo Ministério Público, quando lhe convier

\footnotetext{
${ }^{181}$ FRANÇA, Erasmo Valladão Azevedo e Novaes. Invalidade das Deliberações de Assembléias das S/A. São Paulo: Malheiros Editores, 1999, pág.74.

${ }^{182}$ Invalidade..., pág. 74.
} 
intervir, devendo ser pronunciada de ofício, pelo juiz, vedada, outrossim, sua ratificação."

Mauro Rodrigues Penteado ${ }^{183}$, analisando a posição da doutrina e jurisprudência a respeito do regime especial de anulabilidades que rege os atos e negócios jurídicos realizados no âmbito das sociedades por ações, destaca as críticas feitas por Pontes de Miranda, Tullio Ascarelli e Fábio Konder Comparato, àqueles doutrinadores, dentre eles Trajano de Miranda Valverde e Waldírio Bulgarelli, que defendiam não existir hipóteses de inexistência e nulidade absoluta na legislação que regula as sociedades por ações, mas apenas de nulidades relativas, conclui que a posição defendida pelos primeiros está em conformidade com o regime estabelecido pela Lei 6.404 e os princípios que regem o Direito Societário: "É este entendimento [que admite as hipóteses de nulidade absoluta e inexistência de atos e deliberações das sociedades por ações], sem dúvida o mais acertado, que tem prevalecido no Judiciário, sendo igualmente adotado pela Comissão de Valores Mobiliários. Nesse sentido o Tribunal de Justiça de São Paulo, ao julgar litígio envolvendo acionistas das Indústrias Matarazzo, decidiu que 'sem dúvida, há deliberações nulas e outras apenas anuláveis. A distinção influi sobre a maior ou menor amplitude do círculo de legitimidade de agir. Nas deliberações nulas, a demanda se abre a todo o interessado; nas anuláveis a ação é exercível exclusivamente por área restrita de legitimados. É o que vem destacando a doutrina (cf. Vaselli, Frè, Graziani etc). Candian foi quem melhor efetuou análise classificatória dos defeitos verificáveis nas deliberações de assembléias das companhias. Partiu da observação de existir um núcleo de elementos a caracterizar o ato volitivo colegial. Assim: a) a reunião de sócios; b) o 'quorum' majoritário na deliberação; e c) o objeto possível, jurídica e fisicamente. A falta de um dos referidos elementos implicaria a nulidade 'pleno jure'. Presente esse núcleo fundamental, a falta de qualquer outro elemento importaria em anulabilidade. Essa idéia a presidir o ‘discrime’ entre os vícios vem sendo seguida.” (Grifo nosso).

Negar-se a possibilidade de declarar nulos ou inexistentes determinados atos ou deliberações de uma sociedade por ações teria por consequiência

${ }^{183}$ Aumentos..., págs 279 a 282. 
permitir a ocorrência de situações por vezes absurdas e contrárias à ordem pública ${ }^{184}$, outorgando carta branca aos administradores e controladores de uma companhia a praticar atos, inclusive ilícitos, protegidos pelo sistema legal que rege o Direito Societário e que estabelece prazos curtos de prescrição e restrição quanto às pessoas legitimadas para pleitear a nulidade desses atos, o que permitiria que esses atos nulos convalescesssem ao final do prazo para ajuizamento da ação própria.

A defesa de que os atos societários somente seriam sujeitos ao regime de nulidade relativa, certamente não poderia ser a mais correta, ainda que sob alegação da necessidade de proteção a outros aspectos do Direito Empresarial, como a segurança das operações comerciais e a velocidade em que são realizadas exige para estabilidade das decisões, e proteção de terceiros que contratem diretamente com a sociedade. Essas exigências são válidas e o sistema oferece mecanismos de proteção, mas a impossibilidade de se atacar um ato ou decisão que flagrantemente contrarie o sistema jurídico certamente oferece prejuíos maiores à comunidade e à ordem jurídica.

Assim, o prazo de dois anos previsto no artigo 286, para ajuizar ação visando “...anular as deliberações tomadas em assembléia-geral ou especial, irregularmente convocada ou instalada, violadoras da lei ou do estatuto, ou eivadas de erro, dolo, fraude ou simulação, prescreve em 2 (dois) anos, contados da deliberação"

${ }^{184}$ Conforme MIRANDA, Tratado de Direito Privado. 2a edição. Rio de Janeiro: Borsoi. Tomo 50, 1965., pág. 288: “... a interpretação que se pretende dar ao art. 156 do Decreto-lei n. 2.627 no sentido de abranger o nulo por impossibilidade ou ilicitude é de primarismo revoltante. Como poderia ser apenas anulável a deliberação que consiste em exploração de lenocínio, ou de contrabando, ou de negócios contra a segurança nacional? Como poderia ser apenas anulável a mudança do objeto para caça em Marte? Se o caso é de inexistência, ou de nulidade, pode propor a ação declaração de inexistência, ou a de nulidade, qualquer interessado, e não só o acionista. Não há prazo de prescrição: quod ab initio vitiosum est non potest convalescere; quer se trate de deliberação inexistente, quer de deliberação nula. É absurdo interpretar-se o art. 156 do Decreto-lei n. 2.627 corno se houvesse prescrição de ações de inexistência ou de nulidade da deliberação (cf. GIUSEPPE STOLFI, Teoria del Negozio juridico, 67; AURELIO CANDIAN, Nullità e Annullabilità di delibere di assemblee de la società per azioni, 149: 'Sul fatto che a proposito della delibera nulla non esistono termini di prescrizione o di decadenza dell'azione, che non sia possibile convalida ma, se mai, solo rinnovazione dell'atto, che chiunque abbia diritto di considerarla como inesistente, e, ad es., che amministratore abbia il potere e il dovere di rifiutarne 1'esecuzione, che concordanza')." No mesmo sentido, FRANÇA, Erasmo Valladão Azevedo e Novaes, Invalidade..., pág. 73, analisando os argumentos utilizados para sustentar a inexistência previsão, na Lei das S.A., de atos nulos (nulidade absoluta), mas somente de atos anuláveis (nulidade relativa), exemplifica: "Isso significaria, para dar apenas alguns exemplos mais gritantes, que aos acionistas seria dado, em violação ao disposto no art. 222 da Constituição Federal, eleger um estrangeiro para administrar e orientar intelectualmente uma empresa jornalística, ou modificar os estatutos desta para admitir um acionista pessoa jurídica de capital estrangeiro com mais de trinta por cento do capital social; ou, para ficar na própria Lei n. 6.404, aos acionistas seria permitido modificar os estatutos de uma sociedade de economia mista para excluir a obrigatoriedade de conselho de administração, em infringência ao estabelecido no art. 239; ou, ainda, dispor de direitos de terceiros, que mantivessem relações com a companhia." 
ou o prazo de três anos para as ações movidas contra “...os fundadores, acionistas, administradores, liquidantes, fiscais ou sociedade de comando, para deles haver reparação civil por atos culposos ou dolosos, no caso de violação da lei, do estatuto ou da convenção de grupo", aplicam-se apenas aos casos de nulidade relativa da deliberação. Em ambas as hipóteses, estão legimitados a ajuizar a ação, os acionistas da companhia, administradores, fiscais, controladores ou liquidantes. De qualquer forma, as partes da ação deverão requerer expressamente a anulação da deliberação ou ato e o juiz deverá decidir dentro do pedido formulado pelos autores, restringindo-se sua atuação àqueles atos sobre os quais versar a controvérsia.

Além disso, por se tratar de ato anulável, da mesma forma prevista no artigo 172 do Código Civil, o parágrafo único do art. 285 da Lei das S.A., prevê a possibilidade de retificação da deliberação atacada, afastando o vício que sobre ela incidia, mesmo após o ajuizamento da ação para sua anulação.

No caso dos atos nulos ou inexistentes, a declaração de nulidade ou inexistência poderá ser feita de ofício, no curso do processo, ainda que as partes da ação não requeiram expressamente a verificação da validade do ato ${ }^{185}$. Caso a Junta Comercial competente não detecte o vício do ato e permita seu registro, a ação visando a declaração de nulidade poderá ser ajuizada por qualquer interessado, inclusive terceiros à companhia e o Ministério Público.

De forma semelhante ao sistema adotado no Brasil, o Código Civil Italiano determina no artigo $2379^{186}$, alterado na reforma de $2003^{187}$, a anulação de

\footnotetext{
${ }^{185}$ Código Civil: "Art. 168. As nulidades dos artigos antecedentes podem ser alegadas por qualquer interessado, ou pelo Ministério Público, quando lhe couber intervir. Parágrafo único. As nulidades devem ser pronunciadas pelo juiz, quando conhecer do negócio jurídico ou dos seus efeitos e as encontrar provadas, não lhe sendo permitido supri-las, ainda que a requerimento das partes.

186 "Art. 2379 Nullità delle deliberazioni. Nei casi di mancata convocazione dell'assemblea, di mancanza del verbale e di impossibilità o illecietà dell'oggetto, la deliberazione può essere impugnata da chiunque vi abbia interesse entro tre anni dalla sua iscrizione o deposito nel registro delle imprese, se la deliberazione vi è soggetta, o dalla trascrizione nel libro delle adunanze dell'assemblea se la deliberazione non è soggetta nè a iscrizione nè a deposito. Possono essere impugnati senza limiti di tempo le deliberazioni che modificano l'oggetto sociale prevedendo attività illeciti o impossibili. Nei casi e nei termini previsti dal precedente comma la convocazione non si considera mancante, nel caso di irregolarità dell'avviso se, questo proviene da un comportamento dell'organo di amminstrazione e di controllo della società ed è idoneo a consentire a coloro che hanno diritto ad intervenire, di essere preventivamente avvertiti della convocazione e della data dell'assemblea. Il verbale non si considera mancante se contiene la data della deliberazione e il suo oggetto ed è sottoscritto dal presidente dell'assemblea $\mathrm{o}$, dal presidente
} 
uma deliberação em caso de ausência de convocação da assembléia, falta da ata das deliberações tomadas, impossibilidade ou ilicitude do objeto deliberado.

$$
\text { O parágrafo primeiro do artigo } 2379^{188} \text { também prevê a }
$$

possibilidade de sanar a nulidade que vicia a deliberação, nos casos de ausência de convocação da assembléia ou falta da ata das deliberações tomadas, tratando-se, portanto, de casos de nulidade relativa. As demais hipóteses de nulidade previstas no caput do artigo 2379 são hipóteses de nulidade absoluta que, portanto, poderão ser declaradas a qualquer tempo, por qualquer interessado e "ex officio" pelo juiz, e não apenas pelos acionistas da companhia como medida de proteção do interesse geral dos terceiros afetados pela decisão e para impedir a deturpação do escopo econômico vinculado à utilização das sociedades ${ }^{189}$.

Anulada uma deliberação, os atos praticados em cumprimento a essa deliberação também deverão ser anulados, caso contrário a decisão não seria eficaz e não corrigiria a situação prejudicial à companhia, tendo em vista que a grande maioria das deliberações tomadas pelas Assembléias Gerais tem por objetivo determinar a prática de um ato a ser realizado pelos administradores. Assim, se a decisão que autoriza os administradores a praticar um determinado ato, é invalidada, a única forma eficaz de se determinar que a companhia retorne ao estado anterior ao da deliberação, é através da anulação também do ato praticado em cumprimento à deliberação.

del consiglio di amministrazione o del consiglio di sorveglianza e dal segretario o, dal notaio. Si applicano, in quanto compatibili, il settimo ed ottavo comma dell articolo 2377."

${ }^{187}$ A redação revogada do artigo 2379 previa: "Art. 2379 Deliberazioni nulle per impossibilità o illiceità dell'oggetto. Alle deliberazioni nulle per impossibilità o illiceità dell'oggetto si applicano le disposizioni degli artt. 1421, 1422 e 1423 (2486; att. 209)."

188 "Art.2379 bis Sanatoria della nullità. L'impugnazione della deliberazione invalidata per mancata convocazione, non può essere esercitata da chi anche successivamente abbia dichiarato il suo assenso allo svolgimento dell'assemblea. L'invalidità della deliberazione per mancanza del verbale, può essere sanata mediante verbalizzazione eseguita prima dell'assemblea successiva. La deliberazione ha effetto dalla data in cui è stata presa, salvi i diritti dei terzi che in buona fede ignoravano la deliberazione."

${ }^{189}$ TERRUSI, Francesco. L'Invaliditá..., pág. 134: "Il vizio della deliberazione assembleare relativo ao contenuto dell'atto è contemplato espressamente dal legislatore nel contesto della fattispecie di nullità (art. 2379 c.c.) (...) sotto gli specifici profili dell'impossibilità e dell'illiceità dell'oggetto. (...) Nella disciplina dell'invalidità delle deliberazioni dell'assemblea della società per azioni (...) l'illiceità dell'oggetto, ai sensi dell' art. 2379 c.c., ricorre solo quando il contenuto della deliberazione contrasta com norme dettate a tutela di interessi generali, che trascendono l'interesse del singolo socio o di gruppi di soci e dirette ad impedire deviazioni dallo scopo economico-pratico del rapporto di società (Cass. 9.4.1999, n. 3457, MGC 1999, 791; FI 1999, I, 2248. Conf. Cass. 22.7.1994, n. 6824, RFI 1994, voce Società n. 547548)". 
No entanto, visando a proteção dos interesses dos terceiros de boa-fé que contratam com a companhia e do meio empresarial que necessita de agilidade para conclusão de negócios, é necessário verificar se, na situação apresentada, o terceiro que contratou com a companhia, em decorrência de uma deliberação posteriormente anulada, agiu ou não de boa-fé. Se o terceiro atuou conjuntamente com os acionistas que aprovaram a medida impugnada, com o objetivo de causar um dano à companhia ou possuía informações que lhe permitiam saber que o ato aprovado somente traria benefícios pessoais a alguns acionistas da empresa e que as condições contratadas eram prejudiciais à companhia, o ato não poderá subsistir à anulação da deliberação e o terceiro responderá, solidariamente com os administradores ou acionistas que aprovaram a deliberação, pelos prejuízos causados, nos termos do $\S 5^{\circ}$ do artigo 158 da Lei 6.404. Por outro lado, estando o terceiro de boa-fé, seus direitos devem ser preservados, também em obediência aos mesmos princípios que determinam a segurança dos negócios empresariais.

A doutrina e jurisprudência italianas reconheciam, antes mesmo da reforma legislativa de 2003 , a necessidade de proteção dos direitos de terceiros de boa-fé originados de atos realizados em cumprimento de uma deliberação impugnada, a fim de conferir certeza e estabilidade àqueles que contratam com a companhiam. Tal orientação foi positivada no Código Civil Italiano, após a reforma de 2003, com a nova redação dos artigos 2377 e $2379^{190}$.

Muitas vezes, quando se inicia um conflito entre os acionistas e os administradores da companhia, uma das primeiras medidas que os acionistas minoritários requerem é a apresentação de informações e documentos da companhia. Os acionistas têm garantido, pelo inciso III do art. 109, como direito fundamental, inafastável pela Assembléia Geral ou o Estatuto, a fiscalização da gestão dos negócios sociais, na forma da Lei. Nestes termos, os administradores estão obrigados a prestar as informações e documentos que forem requeridos pelos acionistas, que demonstrem o

190 TERRUSI, Francesco. L'Invaliditá..., pág. 221: “A livello d'insieme giova infine sottolineare l'importanza del richiamo, anchora contenuto nell'art. 2379, ult. Co., c.c., alle previsioni di cui all'art. $2377,7^{\circ}$ co., c.c., dal quale sebbene nei limiti della compatibilità, emerge nitidamente il recepimento - in un contesto di diritto positivo - della tesi prevalente nel vigore delle vecchie norme, intesa a estendere alla declaratória di nullità della deliberazione assembleare il principio di salvezza dei diritti acquistati in buona dai terzi in base ad atti compiuti in esecuzione della deliberazione (cfr. Cass. 10.3.1983, n. 1794, BBTC 1986, II, 403. In dottrina, conf. Graziani 1962, 364; Ragusa 1992, 259 e seg.; contra, invece Campobasso 2002, 361)." 
andamento dos negócios sociais, a composição do quadro societário e os resultados da sociedade. Isto não significa, no entanto, que os acionistas que não participem da administração social têm acesso irrestrito tanto às dependências da companhia quanto aos documentos societários e contábeis da companhia. Esse acesso se dá na forma prevista na Lei 6.404, que estabelece limites e procedimentos para fornecimento dessas informações, justamente para que não ocorram abusos por parte dos minoritários que afetem as atividades da empresa.

Desta forma, os livros societários, onde são registradas as transferências de ações, atas de reuniões da Diretoria e do Conselho de Administração e das Assembléias Gerais e os pareceres do Conselho Fiscal permanecem na sede da sociedade sob os cuidados dos administradores e os acionistas ${ }^{191}$ terão acesso ao seu conteúdo, desde que requeiram aos administradores da empresa, que poderá cobrar o custo de emissão das certidões. Havendo suspeita de irregularidades na escrituração dos livros, os acionistas que representem, pelo menos, $5 \%$ do capital social poderão, nos termos do art. 105, requerer judicialmente a exibição integral dos livros da companhia, se forem apontados atos violadores da lei ou do Estatuto ou haja fundada suspeita de graves irregularidades praticadas por qualquer dos órgãos da companhia.

A medida prevista no art. 105, é excepcional, justificável apenas nos casos de existirem fortes evidências de graves desvios e irregularidades na administração da companhia. O sistema da Lei 6.404 determina que os acionistas terão acesso às informações do andamento dos negócios sociais e aos resultados do exercício, anualmente, antes da realização da Assembléia Geral Ordinária, quando da publicação dos anúncios referidos no art. 133, podendo ainda, os acionistas que assim o desejarem, requerer o envio de cópia desses documentos para exame ( $\S 2^{\circ}$ do art. 133), para possibilitar que todos os acionistas possam analisar, anteriormente à Assembléia, os resultados da empresa e deliberar sobre sua aprovação.

191 Terceiros interessados também têm acesso ao conteúdo dos livros de Registro e Transferência de Ações Nominativas e de Registro e Transferência de Partes Beneficiárias, na forma do $\S 1^{\circ}$ do art. 100 da Lei das S.A.: "\$ $\mathbf{1}^{\mathbf{0}}$ A qualquer pessoa, desde que se destinem a defesa de direitos e esclarecimento de situações de interesse pessoal ou dos acionistas ou do mercado de valores mobiliários, serão dadas certidões dos assentamentos constantes dos livros mencionados nos incisos I a III, e por elas a companhia poderá cobrar o custo do serviço, cabendo, do indeferimento do pedido por parte da companhia, recurso à Comissão de Valores Mobiliários.". 
Nos comentários de Paulo Salvador Frontini, sobre o acórdão da apelação cível 14.402-4-SP, do Tribunal de Justiça de São Paulo ${ }^{192}$, o autor tece considerações sobre a determinação desse Tribunal, de possibilitar à acionista, detentora de $50 \%$ do capital social, acesso às dependências da sociedade, para “...nela exercer atos de posse sobre bens comuns.”. Não obstante o caso versar sobre uma sociedade limitada, os comentários são aplicáveis às sociedades por ações, tendo em vista que, independentemente de se tratar de sócios majoritários ou não, que ocupem ou não cargos na administração da sociedade, somente a sociedade, seja ela uma limitada ou anônima, pode exercer direitos de posse sobre os bens que lhe pertencem pois a existência de patrimônio jurídico autônomo e de personalidade jurídica próprias, determinam limites ${ }^{193}$ para a utilização e exercício de direitos, pelos sócios, sobre os bens da sociedade ${ }^{194}$.

Além disso, o acesso de um acionista, não administrador, também às dependências da companhia, não pode ser irrestrito, sob o risco de causar obstáculos à sua administração. $\mathrm{O}$ acionista tem direito de ingressar no recinto da companhia, nos limites e com os objetivos que a lei determina para que ele possa exercer seus direitos de sócio, tais como, requerer a apresentação de livros e de certidões e examinar os documentos disponibilizados pela administração pertinentes a uma deliberação assemblear ${ }^{195}$. Esses limites se impõem justamente em obediência ao princípio majoritário que determina os rumos das sociedades por ações: na medida em que um acionista, ao ingressar na sociedade, concorda com as regras do Estatuto em

${ }^{192}$ Sociedades..., pág. 163.

${ }^{193}$ A confusão patrimonial dos bens da sociedade com os bens dos sócios, é um dos fundamentos para a desconsideração da personalidade jurídica de uma pessoa jurídica. Não respeitados os limites entre os bens da sociedade e dos sócios, desviam-se as finalidades da constituição da pessoa jurídica, abrindo espaço para ocorrência de abusos.

${ }^{194}$ Por esse motivo, o autor conclui, à pág. 163 (em Sociedades...): “...o que a apelante poderia postular, em termos societários, era o direito de ingresso no recinto da empresa para o fim de poder fiscalizar os negócios sociais; para exercer, pelo exame de documentos e livros, o direito de formalizar objeções e de fazer indagações a respeito do desempenho empresarial da sociedade. Tudo devidamente requerido (art. 290 do CCom), e para o fim último de cobrar resultados, exigir e conferir prestação de contas etc. Esses são direitos do sócio não gerente, a que se acresce, como o de maior relevância, ao ensejo da apreciação das contas anuais, o direito de votar a respeito de sua aprovação ou rejeição."

${ }^{195}$ FRONTINI, Paulo Salvador. Sociedades..., pág. 164: "Esse direito de ingressar nas dependências da empresa não é entretanto irrestrito. Deve, com efeito, ser ressaltado que o sócio não gerente, embora tenha o direito de acesso ao interior do recinto onde a sociedade opera, não tem direito irrestrito de livre circulação nas dependências da sociedade. O direito de acesso existe, sim, em função e nos limites do exercício de seus direitos de sócio. A razão de ser dessa limitação decorre do resguardo que se há de conferir ao sócio-gerente para comandar o empreendimento, pelo qual é responsável. A presença pessoal sem limites de um sócio simples, com o risco de intrometer-se em assuntos gerenciais, é inconveniente em termos de convívio interno: a sociedade comercial poderá tornar-se ingovernável." 
vigor, está, de certa forma forma, delegando à maioria, se ele não a integrar, o poder de decidir sobre a orientação dos negócios da sociedade, desde que no interesse desta última. Da mesma forma, com a eleição dos administradores, o poder de praticar atos de gestão patrimônio social e de representar a companhia, é investido a esses indivíduos. Os acionistas se submetem então às regras legais e estatutárias que estabelecem os procedimentos para fiscalização dessas atividades e do exercício do poder.

Quanto aos prazos de prescrição, para ajuizar ações versando sobre irregularidades nas deliberações, nas Assembléias Gerais ou para reparação dos danos causados na administração das companhias, a Lei das S.A. estabelece:

a) - prazo de 2 anos, contados da deliberação, para o acionista ajuizar ação contra a companhia, para anular as deliberações tomadas em Assembléia Geral ou Especial, irregularmente convocada ou instalada, violadoras da Lei ou do Estatuto, ou eivadas de erro, dolo, fraude ou simulação (art. 286);

b) - prazo de 3 anos, para ajuizar ação contra os acionistas, administradores, fiscais ou sociedade de comando, para deles haver reparação civil por atos culposos ou dolosos, no caso de violação da Lei, do Estatuto ou da Convenção de Grupo, contado o prazo da data da publicação da ata que aprovar o balanço referente ao exercício em que a violação tenha ocorrido (art. 287, "b" "196).

Estão legitimados a ajuizar a ação para reparação de danos causados por controladores à companhia, apenas os acionistas ausentes à Assembléia Geral na qual se deliberou o ato impugnado ou que a ela compareceram e não concorreram com o seu voto para aprovação da deliberação ${ }^{197}$. Os acionistas que contribuíram para formação da maioria e aprovação da deliberação, não poderão, a princípio, impugnar a deliberação por eles próprios aprovada a menos que comprovem que tomaram conhecimento, posteriormente à aprovação da deliberação, de fatos e

${ }^{196}$ O item "g" do art. 287 estabelece ainda o prazo de 3 anos para um acionista ajuizar ação contra a companhia, qualquer que seja o seu fundamento. Entendemos que as ações a que se refere esse artigo, não têm por fundamento as ações que discutam atos de gestão da companhia, as quais estão previstas expressamente no art. 286 e no item "b" do art. 287. Dentre as ações fundamentadas no item "g" do art. 287 estão as que têm por objeto dirimir as dúvidas e fiscalizar os registros realizados nos livros da companhia, nos termos do parágrafo único do art. 103 ou requerer indenização por danos decorrentes de omissão de declarações nos certificados de ações ( $\$ 1^{\circ}$ do art. 24).

${ }^{197}$ FERREIRA, Waldemar. O Direito Insurrecional..., pág. 53. 
informações antes não disponíveis, que comprovem que as informações a que tiveram acesso antes da Assembléia Geral e que contribuíram para a formação de sua convicção eram inverídicas ou incompletas e, portanto, ocorreu erro, dolo, fraude ou simulação, nos termos do artigo 286 da Lei das S.A. ${ }^{198}$ Nesse sentido, o parágrafo $3^{\circ}$ do artigo $134^{199}$ prevê expressamente a possibilidade de responsabilização dos administradores e fiscais, mesmo após aprovação das demonstrações financeiras e das contas, sem reservas, quando, a princípio, estes estariam exonerados de responsabilidade pelo conteúdo desses documentos e pelas operações e resultados deles constantes, quando verificada a ocorrência de erro, dolo, fraude ou simulação.

Ao ajuizar uma ação, ainda que em nome próprio, visando a anulação de uma deliberação contrária à lei ou aos Estatutos, o acionista atua como verdadeiro "órgão de defesa social”, nas palavras de Waldemar Ferreira porque as conseqüências mediatas e diretas da ação repercutem na sociedade e, apenas de forma indireta, tem o acionista seus interesses individuais restabelecidos ${ }^{200}$.

A adoção, pelos tribunais, de uma solução eficaz e em conformidade com os princípios das sociedades por ações, resolvendo a controvérsia de forma eficiente, inclusive do ponto de vista econômico, e pondo fim às questões que afetam o funcionamento da companhia, reparando os prejuízos a ela causados, aumenta a segurança no sistema e em suas instituições e aumentando a eficiência de seus institutos. No entanto, o princípio fundamental de onde deve partir a análise das

198 Sobre esse assunto, bastante controverso na doutrina, confira-se o entendimento de Tullio Ascarelli, Vícios das Deliberações Assembleares. Direitos Individuais dos Acionistas. Prescrição, em Problemas..., nota 1131, pág. 532: "O problema da natureza da ação respeita na prática, antes de mais nada, à possibilidade de o acionista impugnar uma deliberação, embora tenha votado a favor dela. Na Itália a doutrina dominante sustentava a resposta afirmativa, ao passo que a jurisprudência adotava a resposta negativa. No direito brasileiro distinguiam-se, a respeito, várias hipóteses, durante a vigência do Decreto $\mathrm{n}^{\circ}$ 434, de 14 de julho de 1891 (cf. Cf. Carvalho de Mendonça, Tratado, $\mathrm{n}^{\circ} 1.163$ ); no direito alemão do Código de 1897 o problema é legislativamente disciplinado, distinguindo-se os casos em que a ação cabe a qualquer acionista, os em que cabe apenas ao acionista dissidente e os em que cabe apenas a uma minoria; no direito francês (cf. Houpin et. Bosvieux, Traité des Sociétés, $\mathrm{n}^{\circ} 1.192,7^{\mathrm{a}}$ ed.) o acionista que votou a favor da deliberação não pode impugná-la, a não ser quando se trate de uma nulidade de ordem pública; não pode impugnar a deliberação nem sequer o acionista que adquiriu as suas ações depois da assembléia ou - o que é entretanto óbvio - o que tenha deixado de ser acionista."

199 "§ 30. A aprovação, sem reserva, das demonstrações financeiras e das contas, exonera de responsabilidade os administradores e fiscais, salvo erro, dolo, fraude ou simulação."

${ }^{200}$ O Direito Insurrecional..., págs 52 e 53: "Promovendo a anulação das deliberações ilegais ou antiestatutárias, apenas indiretamente defende os seus interesses individuais, porque, mediata e diretamente, de caráter essencialmente social são as conseqüências de sua atuação. A anulação das deliberações, em última análise, determina o restabelecimento das condições anteriores para a sociedade e não propriamente para o acionista, que só por via de conseqüência satisfaz os seus interesses individuais." 
controvérsias envolvendo a gestão das S.A. decorre da liberdade conferida aos acionistas e administradores de determinarem os rumos dos negócios sociais, atendendo a seus critérios de conveniência e oportunidade, desde que suas decisões sejam tomadas de boa-fé e visando o interesse da companhia, ainda que os resultados para a companhia e seus acionistas não sejam os que se esperava alcançar. O mérito da decisão, atrelado ao risco do empreendimento desenvolvido, não pode ser reformado ou substituído pelo Judiciário que se limitará à análise da legalidade das decisões tomadas, de acordo com os preceitos legais e estatutários. 


\section{IV.1. - CONFLITO DE INTERESSES}

A existência de conflitos de interesses é natural para a coletividade, servindo o Direito, para regular o comportamento dos indivíduos e determinar o tratamento a ser utilizado na solução de conflitos de interesses relevantes $^{201}$. Nas sociedades por ações, esse conflito deixa de existir pelo menos por um momento, quando os sócios concluem a negociação das condições para constituição da companhia.

A partir deste momento inicial, diversos fatores que não poderiam ser previstos no momento da constituição da sociedade, especialmente o comportamento das partes envolvidas, influirão decisivamente sobre a regularidade da condução de suas atividades e afetarão, positiva ou negativamente, os interesses, não apenas dos sócios, mas também de terceiros.

A determinação do interesse da sociedade como o "interesse comum a todos os sócios", de remuneração do patrimônio e dos esforços investidos na sociedade, através da realização de suas atividades, com a partilha de lucros e participação no acervo social, é fundamental para orientar a análise das hipóteses de conflito de interesses, previstas no artigo 115 da Lei das S.A.

O princípio básico e geral é que o direito de voto dos acionistas deverá, sempre, ser exercido no interesse da companhia; o voto proferido por acionista em conflito com o interesse da companhia, para obtenção de vantagem particular, é anulável. Se esse voto foi determinante pr obtenção da maioria que aprovou a deliberação, também a deliberação será anulada.

201 SIMIONATO, Frederico Augusto Monte. Sociedades Anônimas..., pág. 87, assim sintetiza o pensamento de Recasens Siches: "Recasens Siches coloca o problema do interesse com precisão. Para o referido professor, os desejos de cada um, isto é, o interesse de cada um, são frequentemente vencidos pelos interesses em conflito e pelos desejos dos outros. Assim, entende-se por interesse o desejo que os seres humanos tratam de satisfazer, individualmente ou em grupos e associações, em suas relações com os demais seres. Como a satisfação de todos os interesses não é possível nascem os conflitos na coletividade." (Grifo no original). 
A parte inicial do parágrafo $1^{\circ}$ do artigo 115 prevê hipóteses taxativas de proibição do exercício do direito de voto, determinando a abstenção do acionista em questão, nas deliberações que versam sobre: (a) laudo de avaliação dos bens conferidos por aquele sócio à sociedade, para integralização do capital por ele subscrito; e (b) aprovação de suas contas como administrador ${ }^{202}$.

A redação do artigo não deixa dúvidas de que, ainda que o acionista possa participar da Assembléia, estará proibido de votar, sendo de fácil verificação a ocorrência de uma dessas hipóteses ${ }^{203}$.

O problema encontra-se na interpretação da parte final do $\S 1^{\circ}$ do artigo 115, que determina a abstenção do acionista nas deliberações “...que puderem beneficiá-lo de modo particular, ou em que tiver interesse conflitante com o da companhia.”. Trata-se de situações que, muitas vezes, apenas após a declaração de voto será possível verificar a existência e a extensão do conflito de interesses entre o sócio e a sociedade, e se o voto proferido visou alcançar um interesse pessoal em deterimento do interesse da sociedade, o que impossibilita vedar o exercício do direito de voto a um acionista, antes deste proferir seu voto ${ }^{204}$.

\footnotetext{
${ }^{202}$ BLACK, Bernard e KRAAKMAN, Reinier. A Self-Enforcing Model..., pág. 43, comparando a eficácia dos sistemas norte-americano e russo, este último implantado após o final do regime comunista, com a colaboração dos autores, entendem que a proibição legal, pura e simples, da realização de um operação somente deveria ser empregada em um sistema jurídico quando a experiência demonstrar que existe pouca justificativa empresarial para realização de uma operação daquela natureza ou se a realização daquela operação provoca um grande risco de abuso, por parte de acionistas e/ou administradores e identificam ainda as seguintes operações que no entendimento dos autores, estariam englobadas nessas situações: empréstimos da companhia para administradores e/ou seus acionistas e realização de pagamentos por uma terceira pessoa para um administrador ou acionista da companhia, relacionados a uma operação entre a companhia e essa terceira pessoal. E sugerem, como procedimentos para proteção dos interesses dos demais acionistas, na realização dessas operações que (a) as operações sejam aprovadas por administradores que não tenham interesse financeiro envolvido nessas operações, e (b) as operações envolvendo valores superiores a um determinado limite ( $2 \%$ do patrimônio da companhia ou de suas receitas, por exemplo), sejam aprovadas por acionistas que não tenham interesse nas operações."

${ }^{203}$ Podem existir situações em que a verificação da nulidade do voto, proferido em conflito de interesses, em alguma dessas hipóteses, demandará maiores investigações, como, por exemplo, nos casos em que uma terceira pessoa, física ou jurídica, relacionada ao sócio, aprova as contas de sua administração ou o laudo de avaliação de bens conferidos ao capital, a seu mando.

${ }^{204}$ Neste sentido, SILVA, Alexandre Couto. A Regra do Julgamento do Negócio: Business Judgment Rule. Belo Horizonte: Faculdade de Direito da UFMG, 2005. Tese apresentada ao Curso de Doutorado da Faculdade de Direito da Universidade Federal de Minas Gerais, ainda não publicada, pág. 55: "A discussão que se coloca em sede doutrinária e jurisprudencial é se tais hipóteses são também de vedação do exercício de direito de voto, tendo o legislador vedado ex ante factum o exercício de tal direito, ou se, na verdade, quando da ocorrência de tais hipóteses, deve permitir que o acionista vote, aplicando-se,
} 
Francesco Terrusi ${ }^{205}$, analisando as alterações introduzidas na redação do artigo $2373^{206}$ do Código Civil Italiano, que trata do conflito de interesses, ressalta que, de acordo com a nova redação desse artigo, o acionista não está mais proibido de participar da deliberação em que tenha um interesse conflitante, como previsto na redação anterior, o qual determinava expressamente que o direito de voto não poderia ser exercido pelo sócio nas deliberações em que tivesse, por si ou por terceiros, um interesse em conflito com o da sociedade" ${ }^{207}$. A atual redação do artigo 2373, introduzida na reforma do Código Civil de 2003, permite que o acionista vote, ainda que ele tenha interesse conflitante ao da sociedade, desde que seu voto seja favorável aos interesses da sociedade.

Desta forma, continua o autor, o sócio não apenas não fica privado do direito de votar e nem tem o direito de voto suspenso, como também não tem a obrigação de se abster de votar na deliberação, a qual somente será anulada se ficar comprovado que o acionista votou em benefício próprio ou de terceiros, contra o interesse da sociedade e, portanto, em seu prejuízo, e o seu voto foi determinante para obtenção da maioria necessária para o resultado da deliberação. Essa modificação no tratamento do direito de voto do acionista com interesse em conflito com o da companhia reflete a evolução do entendimento da doutrina e dos tribunais italianos, segundo o autor ${ }^{208}{ }^{209}$.

posteriormente, um exame casuístico sobre a possibilidade de nulidade do voto proferido. Neste último caso, tais hipóteses somente poderiam ser verificadas ex post factum."

${ }^{205}$ L'Tnvalidità...., pág. 121.

206 “Art. 2373. Conflitto d'interessi. Le deliberazioni approvata con il voto determinante di soci che abbiano per conto proprio o do terzi, un interesse in conflitto con quello della società è impugnabile a norma dellarticolo 2377 qualora possa recarle danno. Gli amministratori non possono votare nelle deliberazioni riguardanti la loro responsabilità.I componenti del consiglio di gestione non possono votare nelle deliberazioni riguardantila nomina, la revoca o la responsabilita dei consiglieri di sorveglianza."

207 "Art. 2373. Conflitto d'interessi. Il diritto di voto non può essere esercitato dal socio nelle deliberazioni in cui egli ha, per conto proprio o di terzi, un interesse in conflitto con quello della società In caso d'inosservanza della disposizione del comma precedente, la deliberazione, qualora possa recare danno alla società, è impugnabile a norma dell'art. 2377 se, senza il voto dei soci che avrebbero dovuto astenersi dalla votazione, non si sarebbe raggiunta la necessaria maggioranza. Gli amministratori non possono votare nelle deliberazioni riguardanti la loro responsabilità (2393). Le azioni per le quali, a norma di questo articolo, non può essere esercitato il diritto di voto sono computate ai fini della regolare costituzione dell'assemblea (2368 e seguente, 2486; att. 209)." (Grifo nosso).

${ }^{208}$ L'Invalidità..., pág. 121: "In particolare, la disposizione di cui all'art. 2373 c.c. non consente di privare il sócio del direitto di votare, né rileva quale causa di sospensione del diritto stesso. Donde, il sócio di conflito di interessi, le cui azioni devono essere computate ai fini della regolare costituizone dell'assemblea, non há l'obbligo di astenersi dalla deliberazione, salvo l'eventuale annulamento della 
Erasmo Valladão Azevedo e Novaes França ${ }^{210}$, analisando a extensão do benefício particular almejado pelo acionista, que caracteriza o conflito de interesses, assim se manifesta: "Percebe-se, assim, tal como no art. 142 do Decreto 434 de 1891 (que reproduziu a redação do art. 15, §10, da Lei 3.150 de 1882, e de idêntico dispositivo do Decreto 164, de 1890), ao fazer referência a 'benefício particular', o legislador não tinha em mente qualquer vantagem ilegal ou abusiva que o acionista perseguisse, mas simplesmente procurou obstar que o acionista votasse um benefício em seu próprio favor, mesmo que legítimo."

Assim, o reconhecimento da existência de interesses internos, externos e da sociedade, que podem ser, em determinadas situações, opostos entre si, levou o legislador a construir regras que determinam os limites e os pesos desses interesses, de forma a permitir a realização das atividades da companhia e, assim, proteger os interesses dos demais acionistas e de terceiros, contra decisões e votos

delibera ove al risultato della votazione abbia concorso in misura determinante il suo voto (App. Milano 5.3.1996, 1553). Su consimile principio si registra generale consenso anche in dotrina (cfr. Rordorf 2005, 2393; Preite 1993, 116 e seg.; Rovelli 1992, 1212 e seg.; Grippo 1985, 389 e seg.; Gambino 1969, 371 e seg.; Sena 1961, 388 e seg. Per una diversa valutazione, Cassottana 1991, 62 e seg.)."

${ }^{209}$ No mesmo sentido, LAURINI, Giancarlo. Poteri e Responsabilità..., pág. 54, ainda analisando a redação anterior do artigo 2373, ressalta que a obrigação do sócio com interesse contrário ao da sociedade é se abster de votar e que a nova redação do artigo 2373 superou a discussão doutrinária que existia acerca do poder conferido ao presidente da Assembléia para excluir o voto do acionista que considerasse ter exercido o direito de voto visando privilegiar um interesse pessoal: "Il legislatore del 1942 si limitò a sancire l'obligo di astensione in quelle deliberazioni in cui sócio avesse un interesse in conflitto con quello della società. Un obbligo, tuttavia, privo di sanzioni e com l'unica consequenza, in caso di violazione, della possibilità per i soci dissenzienti, per gli amministratori e per i sindaci di impugnar ela delibera se il voto fosse stato determinante e la delibera idônea a recare danno alla società (Art. 2373, co.2). (...) La tesi, sicuramente condivisibile, secondo la quale il legislatore del 1942 ha inteso sanzionare lo scorretto esercizio del diritto di voto in assemblea da parte del socio in conflitto di interessi non prevenendolo con un discutibile provvedimento presidenziale di esclusione, ma più semplicemente com l'annullabilità delle delibere assunte con quel voto determinante e dannoso per la società, há trovato piena conferma nel nuovo texto dell'art. $23731^{\circ}$ comma, che si limita a stabilire 'La deliberazione approvata con il voto determinante di soci che abbiano, per conto proprio o di terzi, un interesse in conflitto con quello delle società è impugnabile a norma dell'art. 2377 qualora possa arrecarle danno'. La formula trovata è tale da eliminare ogni dubbio sul travagliato coordinamento trai 1 primo e il secondo comma del vecchio art. 2373, con il conseguente definitivo superamento della tesi del potere/dovere del presidente di escludere della votazione il socio in conflito. Si raggiunge cosi (com'è peraltro nello spirito dell'intera riforma) una notevole semplificazione anche in questo segmento del diritto societário, sganciando la problematica del conflitto di interesse del socio da una regolamentazione basata innanzitutto sull'affermazione di un principio astratto di legalità (art. 2373, comma primo) e collegandola invece strettamente da una parte al senso di responsabilità, correttezza e auto-limitazionje del socio e, dall'altra, alla esistenza di un danno concreto per la società, causato dal voto determinante dal socio in conflitto. Il tutto per valutarsi esclusivamente, ai fini dell'impugnazione, daí soggetti legittimati dall'art. 2377 c.c."

${ }^{210}$ Conflito de Interesses nas Assembléias de S.A. São Paulo: Malheiros, 1993, pág. 73. 
proferidos com a intenção de obter vantagens particulares em prejuízo aos interesses da companhia $^{211}$.

\section{O interesse contrário ao interesse social e que impede a} manifestação de voto pelo acionista ou a atuação do administrador com interesse conflitante deve ser atual e previsível, ainda que referente a um bem futuro ${ }^{212}$ com a obtenção de uma vantagem particular em prejuízo da sociedade ou dos outros sócios.

O interesse da companhia é prejudicado, por esta ter sofrido uma perda, atual ou futura, de valores financeiros ou de direitos, ou ainda por deixar de receber algo ou receber montante inferior ao que poderia, caso a deliberação tivesse sido outra que não a aprovada ${ }^{213}$.

A determinação, pelo juiz, da existência ou não de conflito de interesses entre a sociedade e o acionista ou o administrador, exige que a análise do caso não fique restrita aos aspectos formais envolvidos na aprovação da deliberação ou prática daquele ato ${ }^{214}$. Como sustentamos anteriormente, é neste momento que a exposição da situação completa, em que os acionistas envolvidos e a sociedade se encontram, e não apenas dos fatos envolvendo a deliberação ou ato impugnado, mostrase essencial para auxiliar o juiz na compreensão e determinação da solução mais eficaz para o caso e a extensão do conflito de interesses e do prejuízo causado à companhia.

Somente assim será possível determinar se o acionista colocou seus interesses pessoais à frente dos interesses da companhia e, infringindo o dever de lealdade e boa-fé com os demais acionistas, utilizou a estrutura da companhia para privilegiar um interesse pessoal em sacrifício do interesse social ${ }^{215}$.

${ }^{211}$ SILVA, Alexandre Couto. A Regra..., pág. 59: "Conclui-se que, no tocante ao conflito de interesses, deve-se entender que, além de tal conflito ser substancial, o interesse particular do acionista não só tem natureza extra-social, como também, deve ser contrário e antagônico ao interesse da companhia para que seja caracterizado o conflito. Não basta haver somente um duplo interesse."

${ }^{212}$ HALPERIN, Isaac e OTAEGUI, Julio C. Sociedades Anônimas..., pág. 216.

${ }^{213}$ HALPERIN, Isaac e OTAEGUI, Julio C. Sociedades Anônimas..., pág. 216.

${ }^{214}$ HALPERIN, Isaac e OTAEGUI, Julio C. Sociedades Anônimas..., pág. 216.

${ }^{215}$ HALPERIN, Isaac e OTAEGUI, Julio C. Sociedades Anônimas..., pág. 221. 
O interesse conflitante pode ser do próprio acionista ou administrador ou de terceiro a ele relacionado (cônjuge, parente ou outra empresa da qual seja sócio ou administrador).

Neste sentido, para determinar se uma deliberação poderá ser anulada sob a alegação de que um acionista votou visando um interesse próprio e contrário ao interesse da companhia, deve ser verificado: (a) se o voto proferido pelo acionista beneficiado, com interesse conflitante ao da companhia, foi determinante para aprovação da deliberação; e (b) se a deliberação acarreta um prejuízo à companhia ${ }^{216}$.

Desta forma, ainda que um sócio tenha alcançado um objetivo pessoal, com o resultado da deliberação, deve restar comprovado que o resultado da deliberação causou prejuízo para a companhia. Em conseqüência, podemos concluir que é legítima uma deliberação, ainda que a maioria necessária para aprovação dessa deliberação tenha sido obtida com voto proferido por sócio que obteve benefícios pessoais com a aprovação dessa deliberação, se esta não acarretou prejuízos aos interesses da companhia ${ }^{217}$.

Bernard Black e Reinier Kraakman ${ }^{218}$, analisando as orientações consagradas pela doutrina e jurisprudência norte-americana, que orientam a atuação dos administradores, para os casos envolvendo operações em que um administrador ou acionista possui interesse conflitante com o da companhia, constatam que a análise dessas operações envolve a utilização de um componente cultural quanto à honestidade e equidade envolvidos na operação realizada que, em última análise, leva à verificação dos valores envolvidos na operação são justos.

\footnotetext{
${ }^{216}$ TERRUSI, Francesco. L'Invalidità..., pág. 124. No mesmo sentido, LAURINI, Giancarlo. conforme nota 209 acima.

${ }^{217}$ Nesse sentido, TERRUSI, Francesco. L'Invalidità..., pág. 124: "In questa prospettiva giova altersì precisare che, ai fini dell'annullamento di uma delibera assembleare di uma società di capitali per conflitto di interessi ex art. 2373 c.c., deve ritenersi del tutto irrilevante la circostanza che la delibere stessa consenta al sócio il conseguimento (anche) di um suo personale interesse se, nel contempo, non risulti pregiudicato l'interesse sociale. Il socio, pertanto, può legittimamente avvalersi del próprio diritto di voto per realizzare (anche) un fine personale, qualora, atraverso il voto stesso, egli non sacrifichi, a proprio favore, l'interesse sociale (cfr. Cass. 21.3.2000, n. 3312, NGCC 2001, I, 428)."

${ }^{218}$ A Self-Enforcing Model..., pág. 22: “(ii) a transaction between the company and a director or top manager must be approved by noninterested directors, who should grant approval only if the transaction is fair to the company. (...) In the United States this best practice rests on a cultural understanding that 'fairness' turns largely on price, relative to market price. But in an emerging company, directors and judges may not know what it means for a transaction to be 'fair.'."
} 
Para aferição se os valores da operação questionada são eqüitativos, refletem os valores praticados pelo mercado, e, portanto, se a operação é válida e atende aos interesses da companhia, ainda que a decisão que a aprovou tenha contado com a participação de um acionista ou administrador com interesse conflitante com o da companhia, os autores, propõem a utilização dos seguintes parâmetros iniciais $^{219}$ :

a) - determinação do valor de mercado de um determinado bem deverá considerar o preço pelo qual o vendedor que está suficientemente informado do valor de seu bem e não está obrigado a vender o bem, estaria disposto a vendê-lo;

b) - determinação do valor pelo qual um comprador, que está suficientemente informado sobre o valor do bem e não está obrigado a adquirir o bem, estaria disposto a comprá-lo;

c) - se o bem a ser avaliado for um valor mobiliário negociado no mercado de valores, a pessoa que realizar a avaliação deverá considerar o preço de mercado do valor mobiliário, praticado no mercado por período de, no mínimo, as duas semanas anteriores à avaliação;

d) - se o bem a ser avaliado for a própria ação da companhia, seu valor deverá ser apurado considerando o valor patrimonial da ação, apurado pro rata ao valor patrimonial da companhia, na data de sua avaliação e na forma como estiver organizada e administrada. Para determinação do valor da ação, o avaliador deverá considerar o valor total do capital, o preço que um comprador bem informado estaria disposto a pagar pelas ações daquele tipo, além de outros fatores que possam influenciar a avaliação naquele caso específico ${ }^{220}$.

A partir desses parâmetros, os administradores e/ou acionistas da companhia poderão aprovar uma determinada operação, que envolva um

${ }^{219}$ A Self-Enforcing Model..., pág. 43.

${ }^{220}$ Os autores adotam esses parâmetros, para início da análise do caso e da equidade da operação, não sendo exaustivos e definitivos, pág. 43: "We adopt the following definition, which is still vague but better than nothing." 
administrador e/ou acionista da companhia com interesse conflitante ao dela, apenas se concluírem que a companhia irá receber valores, em bens ou serviços, no mínimo iguais aos praticados pelo mercado ${ }^{221}$. Desta forma, se comprovado que a companhia não sofreu prejuízos com a realização daquela operação porque as condições de sua realização seriam, no mínimo, iguais aos praticados pelo mercado, a participação do acionista interessado em sua aprovação, não afetará a validade da deliberação.

${ }^{221}$ A Self-Enforcing Model..., pág. 45. 


\section{IV.2. - ABUSO DO DIREITO DE VOTO}

Para preservação dos interesses e direitos dos acionistas, especialmente daqueles afastados do poder decisório, e da própria sociedade, o artigo 115 da Lei das S.A. estabelece os parâmetros a serem observados pelo Poder Judiciário, na análise dos casos em que houver suspeita de ocorrência de abuso do direito de voto. $\mathrm{O}$ abuso do direito de voto encontra fundamento ainda no instituto do abuso do direito, positivado nos artigos 187 e 188 do Código Civil de 2002.

O abuso do direito ocorre quando o seu titular o exerce imoderadamente, de forma "anti-social",222, excluídas as situações definidas no artigo 188 do Código Civil, onde a necessidade do titular do direito, de agir em legítima defesa ou a fim de evitar perigo eminente, evitando a deterioração ou destruição da coisa alheia, ou a lesão a pesso - nesses últimos casos, desde que também não sejam excedidos os limites indispensáveis para a remoção do perigo -, excluem a hipótese de abuso.

Anteriormente à positivação do instituto no Código Civil de 2002, a doutrina e a jurisprudência reconheciam a necessidade de regular e determinar os limites para exercício de um direito, para que seu titular não o utilizasse de forma prejudicial a terceiros, extrapolando os objetivos legais, econômicos, sociais, de boa-fé ou pelos bons costumes atribuídos àquele direito e utilizavam os critérios do artigo 160 do Código Civil revogado ${ }^{223}$ para estabelecer os limites que possibilitavam caracterizar ocorrência de abuso do direito.

As duas principais linhas de análise das situações envolvendo abuso do direito, desenvolvidas a partir da jurisprudência francesa do início do século

\footnotetext{
${ }^{222}$ WALD, Arnoldo. Direito Civil..., pág. 278.

${ }^{223}$ De redação semelhante ao atual artigo 188 o qual incluiu, no inciso II, a hipótese de atos praticados para evitar lesão a pessoa.
} 
$\mathrm{XX}^{224}$, enfatizam, de um lado, o caráter subjetivo do ato praticado, com a verificação da intenção do agente como elemento essencial para caracterização do abuso ${ }^{225} \mathrm{e}$, por outro lado, o caráter objetivo, para identificar o abuso do direito e proteger terceiros das consequiências danosas do ato, ainda que o titular do direito não tenha agido intencionalmente.

Desta forma, no âmbito do Código Civil, um ato abusivo, praticado no exercício de um direito, que cause resultados que extrapolam os objetivos sociais, econômicos e de boa-fé que sustentam o exercício daquele direito, gera a obrigação do agente reparar os danos causados, ainda que não venha a ser comprovada a intenção do agente em produzir aquele resultado.

Como ressaltado por Alfredo Lamy Filho e José Luiz Bulhões Pedreira, a definição dos parâmetros contidos no artigo 115, sem procurar exaurir as hipóteses, é intencional e oferece a flexibilidade necessária para que os juízes possam analisar cada caso e oferecer a melhor solução para a situação apresentada 226 : “Ao tentar definir o que se deveria entender por abuso do direito de voto, bem como o comportamento do administrador ou do fiscal, o Projeto adotou 'standards' geralmente aceitos na doutrina (art. 115) - mas com a prudência de deixar campo suficientemente largo para que as práticas comerciais, e a jurisprudência, ao longo do tempo, e em contato com as hipóteses, possam construir a solução definitiva."

\footnotetext{
${ }^{224}$ RODRIGUES, Silvio. Direito Civil: Responsabilidade Civil. São Paulo: Saraiva, 2002. págs. 45 e 49. ${ }^{225}$ RIBEIRO. José Horácio Halfeld Rezende. Abuso do Direito. Contornos de Direito Material e Processual. São Paulo: Revista do Advogado, AASP, Julho de 2008, nº 98, pág. 196: "Podemos imaginar, por outro lado, hipótese na qual o abuso do direito está sendo cometido sem intenção. A prova da intenção do agente é, sem dúvida, daquelas mais diabólicas. Basta considerarmos que o agente não dividiu sua intenção com um terceiro que poderia testemunhar, assim, somente ele poderia confessar, o que, na prática, dificilmente ocorrerá." Entendemos, no entanto, que a apuração da intenção do agente poderá se dar outras formas além da confissão. A análise da situação envolvendo a prática do ato, o conhecimento do indivíduo quanto às consequiências negativas da realização daquele ato e a existência de alternativas menos danosas, disponíveis ao indivíduo e da qual ele fora informado indicam se houve ou não intenção do agente no resultado do ato abusivo.

${ }^{226}$ A Lei das S.A.,..., pág. 213. E prosseguem os autores, à página 237: "O artigo 115 cuida dos problemas do abuso do direito de voto e do conflito de interesses entre o acionista e a companhia. Trata-se de matéria delicada em que a lei deverá deter-se em alguns padrões necessariamente genéricos, deixando à prática e à jurisprudência margem para a defesa do minoritário sem inibir o legítimo exercício do poder de maioria, no interesse da companhia e da empresa."
} 
Silvio Rodrigues ${ }^{227}$, comentando as críticas feitas por parte da doutrina à ampla discricionariedade atribuída ao Judiciário para determinar se a finalidade obtida com o exercício de um determinado direito está em conformidade com a finalidade econômica ou social daquele direito, o que poderia levar a julgamentos baseados em convicções políticas ou ideológicas, rebate essas alegações, fundamentando sua opinião na existência de mais de um grau de jurisdição que permite aos tribunais corrigir as sentenças de primeiro grau que estejam em desacordo com os princípios legais.

A ocorrência de abuso do direito de voto não pode ser declarada anteriormente à manifestação do voto; somente pode ser verificada após análise da situação concreta e de todos os aspectos que envolvem o ato ou fato relacionado ao acionista e que teriam interferido na manifestação do seu voto. Desta forma, o acionista, ainda que dentro dos direitos ou deveres de que é titular, excede os limites e as finalidades vinculadas ao exercício de seus direitos. $\mathrm{O}$ ato praticado está em conformidade com a lei, no entanto, o seu exercício, interfere de modo mais do que necessário na esfera jurídica alheia ${ }^{228}$ e extrapola os limites impostos pelo fim econômico, social, a boa-fé ou os bons costumes conexos à criação desse direito.

Modesto Carvalhosa ${ }^{229}$ assim configura as situações de abuso do direito de voto: "O abuso do exercício do direito de voto configura-se quando o acionista não o exerce com moderação, isto é, contrariamente ao interesse da companhia e dos demais acionistas e com o objetivo de causar-lhes danos, seja cerceando-lhes direitos patrimoniais ou políticos, seja tentando alcançar enriquecimento ou obter vantagem sem justa causa. Com base na teoria do 'abuso do direito de voto', atribui-se ao acionista a prerrogativa de paridade de tratamento. Entende-se esse direito como a

${ }^{227}$ Direito Civil..., pág. 52: "Tal censura não me parece procedente. Em rigor, quando a lei confere um maior âmbito de ação ao juiz, dando-lhe arbítrio para agir, não está transferindo para um homem - o julgador do caso sub judice - a integral possibilidade de decidir como lhe aprouver. Essa delegação de poderes para decidir fora de estreitos limites legais é feita a todo o Poder Judiciário, pois o juiz de primeira instância está sob a fiscalização das instâncias superiores. Assim, por exemplo, se o juiz singular entende que um comportamento foi abusivo e fixa uma indenização, e se a Corte de Apelação unanimemente se pronuncia em igual sentido, é extremamente provável que tal decisão atenda aos ditames da justiça, pois decorreu do pronunciamento de, pelo menos, quatro profissionais versados no mister de julgar, imparciais e de boa-fé. E, a despeito disso, em muitos casos, ainda haverá recursos. De modo que não vejo inconveniente em conferir-se ao julgador aquela margem de liberdade para decidir, acima aludida."

${ }_{228}$ COMPARATO, Fábio Konder. O Poder de Controle...., pág. 364.

${ }^{229}$ Comentários à Lei de Sociedades Anônimas. $2^{a}$ edição. São Paulo: Saraiva, 1998, volume 2, pág. 404. 
coibição do uso do voto por um ou mais sócios para favorecer arbitrariamente alguns acionistas em detrimento de outros. O objetivo de causar dano é inerente à figura do voto abusivo. Configurar-se-á, portanto, o abuso do direito de voto, se este for exercido com a intenção de lesar a companhia ou um acionista, ou um grupo dentre eles."

O artigo 115 deixa claro que o voto proferido será considerado abusivo, se comprovado que o acionista em questão não exerceu seu direito no interesse da companhia e teve a intenção de: (a) causar dano, à companhia ou a outros acionistas, ou (b) obter, para si ou para outrem (pessoa física ou jurídica a ele relacionada), vantagem a que não tenha direito.

Independentemente do objetivo pretendido pelo acionista que proferiu um voto abusivo - causar dano à companhia ou a acionista ou obter vantagem pessoal em prejuízo da companhia ou de outro acionista -, para configuração da hipótese de abuso do direito de voto, deve ficar comprovado que o resultado por ele pretendido acarretaria um prejuízo, atual ou futuro, para a companhia ou para outros acionistas. Nos termos do $\S 3^{\circ}$ do artigo 115 , o acionista responderá pelos danos causados, à companhia ou ao acionista que teve intenção de prejudicar, ainda que seu voto não haja prevalecido.

$\mathrm{Na}$ hipótese de o voto abusivo ter sido determinante para o resultado da deliberação, o vício que macula o voto acarreta a possibilidade de anulação da deliberação e das operações que tenham sido praticadas em seu cumprimento, ressalvados os direitos de terceiros de boa-fé, a serem apurados no caso concreto. A ação para requerer a anulação da deliberação prescreve em 2 anos contados da deliberação (art. 286) e para requerer reparação dos prejuízos causados, em 3 anos, contados da data da publicação da ata que aprovou o balanço do exercício em que a violação ocorreu (art. 287).

As disposições do artigo 115 evidenciam dois princípios fundamentais que regem não apenas as sociedades por ações, mas também as sociedades em geral: a necessidade de o acionista buscar, sempre, atender os interesses da sociedade e o dever de agir lealmente e de boa-fé, não apenas com a companhia, mas também com os demais acionistas. 
Os deveres de lealdade e boa-fé que são de observância obrigatória a todos os acionistas, e especialmente, aos acionistas controladores, pelo poder neles concentrado de determinar os rumos da sociedade e, portanto, causar maiores prejuízos, à companhia e seus acionistas, está ainda de acordo com os princípios que regem os negócios jurídicos nos termos do 422 do Código Civil que estabele os princípios da probidade e da boa-fé na conclusão e execução dos contratos em geral.

No caso específico das sociedades por ações, independentemente do número de sócios ou da companhia ser de capital aberto ou fechado, que demonstra maior ou menor grau de affectio societatis entre os sócios, a observância desses princípios na condução dos negócios sociais é fundamental para permitir a realização dos objetivos da empresa e a convivência harmônica entre os sócios.

Desta forma, caso a companhia venha a sofrer prejuízo pela declaração do voto abusivo, esse prejuízo atingirá também os acionistas, ainda que não diretamente, pela desvalorização do patrimônio da empresa ou perda de oportunidades comerciais. São diversas as situações verificadas no dia-a-dia das companhias, em que acionistas utilizam indevidamente seu direito de voto, desviando-se do objetivo principal para o qual a lei lhes assegura esse direito fundamental. Quando não se corrige esse desvio e o acionista continua atuando de forma abusiva, quebra-se o affectio societatis existente entre os sócios, instaurando disputas internas que podem levar à paralisia da empresa.

No entanto, nem sempre a companhia é diretamente prejudicada pelo exercício abusivo do voto de um acionista. Uma situação bastante comum, comentada por Mauro Rodrigues Penteado ${ }^{230}$, de exercício de voto abusivo com o

${ }^{230}$ Aumentos..., pág. 263: “A solução acolhida pela Lei n. 6404, no entanto, é mais ampla (o Autor se refere à posição defendida por Mengoni com base na legislação italiana, de que não existiria hipótese em que os acionistas seriam diretamente afetados pelo voto proferido em abuso do direito): com isto, a alternativa expressamente prevista tende a pôr cobro às discussões a que acima nos referimos, acerca da suposta neutralidade do aumento de capital; ainda que se pretenda sustentar, entre nós, que determinada operação de aumento de capital não causa 'danno per la società, allaquale non può nuocere il fatto di avere in cassa del danaro in più (Cf. Trimarchi), mesmo assim o fato de causar ela dano ao acionista 
objetivo de prejudicar exclusivamente outros sócios, mas que não necessariamente acarreta prejuízos à companhia, ocorre quando acionistas propõem aumento de capital para a companhia, com o objetivo de prejudicar outros acionistas que não possam acompanhar esse aumento naquele momento e, portanto, terão suas participações diluídas. Ainda que a companhia não sofra prejuízos com o aumento de valores em caixa, se não existe justificativa, fundamentada no interesse da companhia, para realização do aumento de capital naquele momento, os acionistas que tiveram redução em suas participações sofrerão prejuízos e poderão, com fundamento no artigo 115 da Lei das S.A. e comprovando a inexistência de interesse da companhia e a abusividade dos votos proferidos, requerer a anulação da deliberação, se os votos abusivos tiverem sido decisivos para sua aprovação e reparação dos danos sofridos.

A determinação da existência de voto abusivo, portanto, decorre da análise do objetivo do acionista que o proferiu, de causar dano a outros sócios ou à companhia e sua verificação somente poderá ocorrer após a declaração de voto e análise dos fatos envolvendo a companhia e o sócio que proferiu o voto, para, somente então, anular-se o voto abusivo e responsabilizar-se o acionista pelos danos e prejuízos causados, ainda que seu voto não haja prevalecido.

Por este motivo, entendemos que não se pode impedir previamente um acionista de votar ou a realização de uma assembléia geral apenas pela suspeita de que acionistas poderão proferir voto abusivo com o intuito de prejudicar os demais sócios ou a companhia.

impugnante, associado à falta de justificativa de sua necessidade para o interesse da companhia, caracterizará os votos que a aprovaram como abusivos, ao teor do art. 115." 


\section{IV.3. - ABUSO DO PODER DE CONTROLE}

A consagração do princípio majoritário para tomada das decisões e administração das companhias, impôs a necessidade de regulação e limitação dos poderes e deveres dos acionistas majoritários, para procurar impedir a opressão dos minoritários e o desvio desse poder de controle, em detrimento dos demais acionistas, da própria companhia ou dos demais interesses afetados pelo exercício do poder de controle.

O princípio majoritário retira dos demais acionistas minoritários, a livre disposição dos bens que investiram na sociedade e confere ao controlador o poder de dispor desses bens e do patrimônio da companhia, através da decisões que determinarão os rumos de suas atividades.

O acionista, ao ingressar em uma companhia e a ela conferir parte de seus bens, concordando com a legislação que rege esse tipo societário e as regras contidas no Estatuto Social, está, de certa forma, renunciando à sua vontade pessoal na gestão dos bens que integram o patrimônio da sociedade e submetendo-se, por antecipação, à vontade da maioria ${ }^{231}$.

No entanto, essa abdicação do acionista à perseguição de seus próprios interesses está diretamente vinculada ao fato de que aqueles que irão administrar o patrimônio social deverão, sempre, buscar atingir o interesse da companhia e não seus interesses pessoais ${ }^{232}$. O acionista controlador passa a ter o dever

${ }^{231}$ FERREIRA, Waldemar. O Direito Insurrecional..., pág. 12.

${ }^{232}$ Cooper Royer, Pere \& Fils, Traité des Sociétés, apud Waldemar Ferreira. O Direito Insurrecional..., pág. 12, o consentimento dos acionistas a que a maioria administre o patrimônio social “... não é dado senão sob a condição implícita e necessária de repousar aquela vontade soberana sobre vontades emitidas no interesse social. Este interesse social pode ter maior ou menor compreensão. Possível é engano da parte da maioria. Mas sua vontade deve promanar do interesse social. Se ela procede, manifestamente, de interesse egoísta, ou de maneira geral, antisocial, o consentimento dado por antecipação pelo subscritor que fez o abandono de sua vontade não pode ser prejudicado." 
de agir no interesse da companhia, conduta que é inerente ao poder hierárquico que lhe é conferido para controle e gestão do patrimônio alheio. Enquanto aos demais acionistas é assegurado o direito de votar, visando os interesses sociais, o acionista controlador tem o dever de votar e dirigir os negócios da companhia para realizar os interesses desta.

Podemos traçar um paralelo entre o sistema de controle majoritário das S.A. e o princípio democrático de direito que tem por fundamento a teoria da separação de poderes sistematizada por Montesquieu. Em ambos os casos, o poder deve ser exercido de acordo com princípios estabelecidos em uma lei maior (Constituição Federal, a legislação societária ou Estatuto Social) que, em um primeiro momento, é determinada por todos os aqueles que irão a ela se submeter (o povo ou os acionistas). A separação dos poderes e dos órgãos societários, com competências e poderes próprios e observância de um interesse maior e comum, garante o funcionamento do sistema e fornece subsídios para verificar a ocorrência de abusos.

O exercício do poder deve ser conduzido sempre em conformidade com esses princípios e ambos os sistemas, político-democrático e majoritário, estabelecem a forma de determinação das pessoas encarregadas de exercer o poder, que, necessariamente utilizarão, no exercício desse poder uma parcela de discricionariedade.

Ao analisarmos os atos praticados pelos agentes de poder público, verificamos que a estrutura de repartição dos poderes não sobrepõe um poder sobre outro mas cria mecanismos que possibilitam o controle recíproco sobre os atos praticados dentro da competência de cada um dos poderes, estabelecendo limites ao exercício dos poderes conferidos aos agentes internos.

Da mesma forma, as sociedades por ações possuem órgãos internos aos quais são atribuídos poderes e competência específicos, complementares entre si e que possibilitam o funcionamento da sociedade e formam uma hierarquia organizada que permite, tanto aos acionistas da companhia como aos observadores externos, verificar a legalidade de uma decisão ou de um ato. 
As regras que conferem poder discricionário, tanto no Direito Administrativo como no Societário, para tomada de decisões, contém termos abertos, que deverão ser interpretados pelo Judiciário, a quem caberá verificar se o poder conferido àquela pessoa foi exercido dentro dos limites e objetivos pretendidos pela lei e visando o interesse público, no caso de atos administrativos, ou da sociedade, no caso de atos societários.

O poder de controle será exercido de forma discricionária desde que observados os limites e pressupostos estabelecidos nas regras, legais ou estatutárias, que justamente conferem legitimidade aos atos praticados pelos titulares desse poder. No entanto, considerando a abertura e generalidade dos conceitos contidos nessas regras que, como vimos, não exaurem as hipóteses nelas contidas e, para evitar a ocorrência de abusos no exercício do poder caberá ao Poder Judiciário, em última instância, analisar os casos envolvendo abusos no poder de controle.

A evolução que levou à consagração do princípio majoritário para administração e controle das companhias ressaltou, por outro lado, a necessidade de se proteger os interesses dos minoritários nas situações em que o controlador age de forma abusiva e prejudicial a seus interesses e da companhia. Os mecanismos que oferecem essa proteção, constam, em maior ou menor número e com grandes variações quanto à força das sanções impostas e, maior ou menor grau de flexibilidade em sua imposição pelos tribunais, em todos os sistemas legais ${ }^{233}$.

O fato de caber ao Judiciário determinar, em última instância, se houve ou não abuso no poder de controle por parte de um agente, tanto do poder público quanto de uma companhia, não confere a ele o poder de substituir as decisões que, de acordo com as regras de organização dos poderes, caberiam àquele agente.

233 CONAC, Pierre-Henri, ENRIQUES, Luca e GELTER, Martin. Constraining Dominant Shareholders'..., pág. 04: "All jurisdictions supply corporations and their stakeholders with a number of legal tools to prevent or punish asset diversion by those, whether managers or dominant shareholders, who are in control. Fiduciary duties, disclosure provisions, shareholder approval requirements, liability suits, actions to have self-dealing transactions declared void, criminal sanctions and administrative intervention are available, often jointly, to protect the interests of minority shareholders and other stakeholders against insiders' opportunism." 
A análise feita pelo Poder Judiciário definirá, no caso concreto, se o ato praticado ou a decisão tomada, observou os procedimentos estabelecidos por lei para legitimá-lo e se o agente que o praticou objetivou a consecução do bem comum: o interesse social.

Para isso, a atual Lei das S.A., em sintonia com a doutrina e jurisprudência da época em que foi promulgada, inovou, reconhecendo, na redação do artigo 116 a existência não apenas desse poder de controle, como também dos interesses conexos ao seu exercício, e estabeleceu limites ao exercício efetivo desse poder, exemplificando, no artigo 117, modalidades do exercício abusivo do poder de controle.

\section{Alfredo Lamy Filho e José Luiz Bulhões Pedreira ${ }^{234}$,} comentando a discussão pública que se seguiu à apresentação do anteprojeto da Lei das S.A., com relação aos princípios adotados no artigo 117 que regulam os limites para exercício do poder de controle, assim se manifestaram: "Esse dispositivo - que atinge por igual a controladores nacionais e estrangeiros - é certamente norma pioneira na busca de uma disciplina necessária para o relacionamento eqüitativo entre a empresa e a comunidade em que trabalha, independentemente da origem do capital, ao mesmo passo em que procura dar proteção à empresa como um todo, o que compreende os interesses da maioria, e dos que nela ou para ela trabalham. Os casos que a este se seguem, na enumeração do Art. 131 (117 da lei) citado, visam a fixar normas de procedimento ético do administrador de fato, que é o acionista controlador - a que se vão justapor às que balizam os deveres e responsabilidades dos administradores de direito (arts. 168 a 175 do Anteprojeto e 153 a 160 da lei)."

O titular do poder de controle exerce esse poder dentro dos limites legais e estatutários, visando, sempre, realizar os objetivos da sociedade e proteger seus interesses, devendo ainda respeitar os interesses externos vinculados ou dependentes da existência da sociedade e que merecem proteção legal pela relevância da atividade econômica da companhia na realização das políticas econômicas do Estado.

${ }^{234}$ A Lei das S.A...., pág. 154. 
Procura assim, a lei, estabelecer o equilíbrio entre os interesses internos e externos existentes nas S.A. e que devem ser respeitados pelos acionistas controladores. Para isso, o artigo 117 exemplifica, de forma não taxativa ${ }^{235}$, quais são esses interesses, determinando ainda que os interesses dos sócios não poderão se sobrepor aos interesses externos, como afirma Fábio Konder Comparato ${ }^{236}$ : "Isto posto, a harmonização dos interesses internos e externos à empresa faz-se naturalmente, no sentido da supremacia dos segundos sobre os primeiros na hipótese de conflito. O direito ao lucro ou à expansão da empresa não é garantido contra os interesses da comunidade local, regional e nacional em que ela se insere; interesses esses não só de ordem econômica (independência tecnológica ou economia cambial, por exemplo), como também de ordem social em sentido amplo (proteção do meio ambiente, dos interesses dos consumidores, ou do patrimônio cultural)."

O Colegiado da CVM, dentro de suas atribuições, aprovou a Instrução 323, de 19.01.2000, indicando, de forma exemplificativa ${ }^{237}$, as hipóteses de

${ }^{235}$ Neste sentido: REsp 798.262, j. 06.02.2007, $3^{\text {a }}$ Turma, Relatora Ministra Nancy Andrighi, maioria: “A Lei das Sociedades Anônimas adotou padrões amplos no que tange aos atos caracterizadores de exercício abusivo de poder pelos acionistas controladores, porquanto esse critério normativo permite ao juiz e às autoridades administrativas, como a Comissão de Valores Mobiliários (CVM), incluir outros atos lesivos efetivamente praticados pelos controladores."

${ }^{236}$ O Poder de Controle ..., pág. 365.

237 “Art. 1 ' São modalidades de exercício abusivo do poder de controle de companhia aberta, sem prejuízo de outras previsões legais ou regulamentares, ou de outras condutas assim entendidas pela CVM: I - a denegação, sob qualquer forma, do direito de voto atribuído, com exclusividade, por lei, pelo estatuto ou por edital de privatização, aos titulares de ações preferenciais ou aos acionistas minoritários, por parte de acionista controlador que detenha ações da mesma espécie e classe das votantes; II - a realização de qualquer ato de reestruturação societária, no interesse exclusivo do acionista controlador; III - a alienação de bens do ativo, a constituição de ônus reais, a prestação de garantias, bem como a cessação, a transferência ou a alienação, total ou parcial, de atividades empresariais, lucrativas ou potencialmente lucrativas, no interesse preponderante do acionista controlador; IV - a obtenção de recursos através de endividamento ou por meio de aumento de capital, com o posterior empréstimo desses recursos, no todo ou em parte, para sociedades sem qualquer vínculo societário com a companhia, ou que sejam coligadas ao acionista controlador ou por ele controladas, direta ou indiretamente, em condições de juros ou prazos desfavoráveis relativamente às prevalecentes no mercado, ou em condições incompatíveis com a rentabilidade média dos ativos da companhia; V - a celebração de contratos de prestação de serviços, inclusive de gerência e de assistência técnica, com sociedades coligadas ao acionista controlador ou por ele controladas, em condições desvantajosas ou incompatíveis às de mercado; VI - a utilização gratuita, ou em condições privilegiadas, de forma direta ou indireta, pelo acionista controlador ou por pessoa por ele autorizada, de quaisquer recursos, serviços ou bens de propriedade da companhia ou de sociedades por ela controladas, direta ou indiretamente; VII - a utilização de sociedades coligadas ao acionista controlador ou por ele controladas, direta ou indiretamente, como intermediárias na compra e venda de produtos ou serviços prestados junto aos fornecedores e clientes da companhia, em condições desvantajosas ou incompatíveis às de mercado; VIII - a promoção de diluição injustificada dos acionistas não controladores, por meio de aumento de capital em proporções quantitativamente desarrazoadas, inclusive mediante a incorporação, sob qualquer modalidade, de sociedades coligadas ao acionista controlador ou por ele controladas, ou da fixação do preço de emissão das ações em valores substancialmente elevados em relação à cotação de bolsa ou de mercado de balcão organizado; IX - a 
exercício abusivo do poder de controle e de infrações graves, aplicáveis às sociedades por ações de capital aberto complementando, assim, a regra do artigo 117. A ocorrência das condutas indicadas no artigo $1^{\circ}$ desta Instrução, ou de outras condutas identificadas pela CVM, caracteriza infração grave, para os efeitos do art. $11, \S 3^{\circ}$, da Lei $n^{\circ}$ 6.385/76, sujeitando o acionista controlador, os administradores da companhia, os integrantes de seus órgãos técnicos ou consultivos, bem como quaisquer outras pessoas naturais ou jurídicas que tenham concorrido para a prática das condutas a que se refere $o$ caput deste artigo, às penalidades previstas no artigo $1^{\circ}$ da Lei ${ }^{\circ} 6.385$.

O desvio de finalidade na utilização do poder de controle caracteriza o abuso, entendendo-se por desvio, na lição de Fábio Konder Comparato, "uma via direta que deixou de ser seguida, para se atingir um alvo ou se chegar a um resultado. Supõe-se, pois, antes de tudo, a falha de um objetivo ou finalidade, impostos pelo direito, ou aberratio finis legis, como já foi dito, em paráfrase à consagrada expressão do direito penal. Mas desvio de finalidade esse compatível com a observância das regras de procedimento formal, que disciplina o exercício do poder, o que torna o ato particularmente perigoso, pela dificuldade em que se encontram os prejudicados de comprovar a ilicitude; o desvio de poder consiste, assim, num afastamento não da forma mas do espírito da lei, representando ato típico de fraus legis, e não contra legem..."

promoção de alteração do estatuto da companhia, para a inclusão do valor econômico como critério de determinação do valor de reembolso das ações dos acionistas dissidentes de deliberação da assembléia geral, e a adoção, nos doze meses posteriores à dita alteração estatutária, de decisão assemblear que enseje o direito de retirada, sendo o valor do reembolso menor ao que teriam direito os acionistas dissidentes se considerado o critério anterior; X - a obstaculização, por qualquer modo, direta ou indiretamente, à realização da assembléia geral convocada por iniciativa do conselho fiscal ou de acionistas não controladores; XI - a promoção de grupamento de ações que resulte em eliminação de acionistas, sem que lhes seja assegurada, pelo acionista controlador, a faculdade de permanecerem integrando o quadro acionário com, pelo menos, uma unidade nova de capital, caso esses acionistas tenham manifestado tal intenção no prazo estabelecido na assembléia geral que deliberou o grupamento;XII - a instituição de plano de opção de compra de ações, para administradores ou empregados da companhia, inclusive com a utilização de ações adquiridas para manutenção em tesouraria, deixando a exclusivo critério dos participantes do plano o momento do exercício da opção e sua venda, sem o efetivo comprometimento com a obtenção de resultados, em detrimento da companhia e dos acionistas minoritários; XIII - a compra ou a venda de valores mobiliários de emissão da própria companhia, de forma a beneficiar um único acionista ou grupo de acionistas; XIV - a compra ou a venda de valores mobiliários em mercado, ou privadamente, pelo acionista controlador ou pessoas a ele ligadas, direta ou indiretamente, sob qualquer forma, com vistas à promoção, pelo acionista controlador, do cancelamento do registro de companhia aberta; XV - a aprovação, por parte do acionista controlador, da constituição de reserva de lucros que não atenda aos pressupostos para essa constituição, assim como a retenção de lucros sem que haja um orçamento que, circunstanciadamente, justifique essa retenção." 
A determinação dos parâmetros que devem ser observados pelos controladores na administração das companhias e os limites de intervenção do Poder Judiciário nas decisões por eles tomadas, acompanha a construção doutrinária e jurisprudencial que trata do controle judicial dos atos administrativos discricionários, conforme discutido no Capítulo IV acima.

À semelhança do que ocorre nas sociedades por ações, o juiz, ao analisar um caso envolvendo eventual abuso do poder discricionário no âmbito da administração pública deverá, em primeiro lugar, aferir o significado concreto do conceito aplicável àquele ato, para, somente então, verificar se, no caso em análise, a decisão tomada foi razoável e justificável para o caso.

Ainda que conclua ter ocorrido abuso de poder, o juiz não poderá substituir a decisão tomada pelo agente. Nas palavras de Paulo Magalhães da Costa Coelho $^{238}$, "...o Poder Judiciário exercerá um controle sobre a concretização do conceito, aferindo se naquela hipótese seria ela [a decisão] a única solução justa, preconizada pela lei que criou o conceito jurídico indeterminado."

O legislador impõe, ao acionista controlador, a obrigação de sanar as perdas e danos sofridos pela companhia em razão do ato por ele praticado com abuso de poder, com o pagamento de prêmio ao acionista que ajuizou a ação. Entendemos que na hipótese de prejuízos causado aos terceiros (cujos interesses estão englobados no conceito de função social da empresa e no parágrafo único do art. 116), também o controlador deve pessoalmente se responsabilizar pelos prejuízos causados pelo uso abusivo do poder. Não poderia a lei adotar solução diferente pois a responsabilização da sociedade nessas situações, acarretaria uma sanção indireta também aos acionistas minoritários que não são responsáveis pela prática do ato.

Nos autos do REspecial n ${ }^{\circ}$ 633.338-DF, julgado em 05.09.2006, DJ 04.12.2006, discutiu-se a possibilidade de se redirecionar a execução proposta inicialmente em face de uma companhia para sua controladora, sob o argumento de que

${ }^{238}$ Controle Jurisdicional da Administração Pública. São Paulo: Saraiva, 2002, pág. 111. E conclui: “Em arremate, o processo de aplicação de um conceito jurídico indeterminado é menos volitivo que interpretativo. Cuida-se, em última análise, da interpretação da lei que criou o conceito jurídico indeterminado." 
a controladora "...estaria promovendo o esvaziamento do patrimônio da companhia." A Ministra Nancy Andrighi, no Voto-Vista (vencido) proferido nesses autos, concluiu que “...todos os atos do controlador, relacionados pelo arresto, ou são ilícitos, ou foram praticados por abuso de direito, com o intuito de prejudicar terceiros (intuito esse expressamente reconhecido no acórdão, que pondera que 'tudo foi feito com um único e claro objetivo: prejudicar os acionistas minoritários, os ora apelados, de forma a impedir que recebessem os direitos que lhe foram reconhecidos na sentença executada'). A aptidão de atos dessa natureza para autorizar a desconsideração da personalidade jurídica da empresa resta pacífica neste Tribunal (REsps. $n^{\circ}$ 86.502/SP, Relator Min. Ruy Rosado de Aguiar, DJ de 26/08/1996; REsp. n 158.051/RJ, Rel. Min. Barros Monteiro, DJ de 12/04/1999). Ora, interpretando hipóteses de desconsideração de personalidade jurídica, esta Terceira Turma tem sempre se posicionado no sentido de admitir que ela seja promovida incidentemente no processo, mesmo de execução, sem enxergar, nisso, qualquer cerceamento ao direito de defesa." ${ }^{, 239}$

$\mathrm{O}$ ato abusivo é praticado pelo acionista controlador e o desvio de sua finalidade retira a legitimidade do ato, ainda que todas as formalidades legais tenham sido observadas e, portanto, somente ele deve suportar as conseqüências que a prática daquele ato ocasionar, devendo indenizar a sociedade pelos prejuízos por ela sofridos e arcar com o pagamento dos valores devidos ao minoritário autor da ação.

Uma das formas de abuso de poder mais freqüentes, considerada por parte da doutrina a hipótese "paradigmática" de opressão dos acionistas minoritários, é através da aprovação de um aumento de capital desnecessário para a sociedade, com o intuito de diluir a participação dos minoritários que não puderem acompanhar tal aumento para manter suas participações ${ }^{240}$. Para que tal deliberação seja

\footnotetext{
${ }^{239}$ Entendemos que, no caso julgado no REsp 633.338,-DF, a responsabilidade do controlador não se daria através de desconsideração da personalidade jurídica e sim por responsabilidade direta do acionsita controlador, contra quem a ação deveria ter sido ajuizada. No entanto, verificando que a ação em questão tramitou por 12 anos, até julgamento pelo STJ, concluímos que a interpretação do caso e a aplicação do instituto da desconsideração da personalidade jurídica serviu como meio de se evitar a ineficácia de todos os atos praticados até aquele momento e atingir as finalidades pretendidas pelo Autor.

240 PENTEADO, Mauro Rodrigues. Aumentos de Capital..., págs. 137 e 138: "Com base nesses ensinamentos, parece-nos lícito asseverar que o procedimento de aumento de capital mediante subscrição de ações pode ser qualificado como vinculado ou formal, no sentido de que pressupõe a estrita observância dos requisitos e formalidades previstos em lei. Essa vinculação, todavia, não significa negar a margem de discricionariedade com que contam os acionistas, reunidos em assembléia geral extraordinária, ou o conselho de administração, nos limites da autorização contida no estatuto, de ajuizar
} 
anulada, no entanto, é necessário, além da comprovação do prejuízo causado aos minoritários - no caso, a diluição de suas participações - a comprovação da intenção do controlador de prejudicar os minoritários. Para isso, é necessário verificar se a companhia tem ou não necessidade de receber os aportes de capital decorrentes do aumento e a veracidade da justificativa do aumento de capital apresentada pelos administradores e acionistas que propuseram o aumento.

$\mathrm{Na}$ verificação da legitimidade de um aumento de capital aprovado, os acionistas e eventualmente os tribunais que venham a analisar o caso devem partir da análise quanto à veracidade da justificativa apresentada pelos controladores e administradores da companhia e de sua situação financeira e patrimonial, se está de acordo com os objetivos pretendidos para o aumento de capital aprovado, especialmente em relação ao disposto no $\S 1^{\circ}$ do artigo 170 , que dispõe sobre os critérios para fixação do preço de emissão de ações, sem diluição injustificada da participação dos antigos acionistas e o inciso III e o $\S 3^{\circ}$ do artigo 163 que estabelece competência do Conselho Fiscal para participar das reuniões dos órgãos administrativos e opinar sobre as propostas que serão submetidas à Assembléia Geral ${ }^{241}$.

Ocorrendo impugnação da deliberação que aprova o aumento de capital da sociedade, por acionista que alegue haver incorrido em prejuízos em razão dessa operação e que esta não visava atender aos interesses sociais, caberá ao acionista controlador o ônus de comprovar a necessidade de realização do aumento de capital no

a oportunidade e a conveniência da operação, bem assim de suas condições, que, em linha de princípio, tal como frisamos nos itens 10 e 18, acima, é facultativa e deve ser decidida pelos órgãos competentes da companhia. Qualificar o procedimento em estudo como vinculado importa, sob o aspecto extrínseco, em realçar os requisitos de validade a que está subordinado, circunscrevendo devidamente a latitude discricionária dos acionistas controladores e dos administradores na matéria, na medida em que um dos requisitos essenciais impostos pela lei é a proposta justificativa do aumento de capital, que deve explicitar os seus fundamentos. Tendo presente que, não raro, os aumentos de capital são realizados com fins não econômicos, razão por que alguns autores chegam a reputá-lo como hipótese 'paradigmática' de opressão aos acionistas não controladores, a ênfase emprestada ao aspecto formal da operação tem a inegável vantagem de situar adequadamente o terreno da discussão, quando da verificação de tais situações."

${ }^{241}$ Conforme PENTEADO, Mauro Rodrigues. Aumentos de Capital..., pág. 170: "A obrigatoriedade de justificação pormenorizada de toda a operação deflui, ainda, da análise sistemática de dois dispositivos da Lei n. 6.404. O primeiro deles é o que trata do preço de emissão das novas ações (art. $170, \S 1^{\circ}$ ), com a previsão do cômputo de critérios determinados, que serão examinados no item subseqüente. O segundo é o que trata da participação do conselho fiscal nos aumentos de capital (art. 163, inc. III e $\S 3^{\circ}$ ); com efeito, os conselheiros fiscais deverão não apenas dar parecer sobre a proposta relativa ao aumento de capital, como, também, assistir às reuniões dos órgãos de administração em que foi aprovado esse documento, a fim de que disponham de informações pormenorizadas para respaldar o seu parecer, que poderá inclusive ser desfavorável, caso a justificação seja incompleta." 
interesse da companhia, assim entendido como o “...interesse comum dos sócios, ou, então, se for o caso, que a mesma foi ditada por interesses comunitários ou nacionais." 242

A jurisprudência italiana também segue os mesmos princípios, estabelecendo os limites dentro dos quais o poder de controle deve ser exercido e em que o Judiciário pode intervir nas deliberações tomadas, caso fique comprovado o abuso ou excesso de poder: “...enquanto a deliberação, ainda que adotada na forma legal e com a maioria prescrita, resulte arbitrariamente e fraudulentamente dirigida à realização, pelo sócio majoritário, de interesses divergentes dos da sociedade ou ainda voluntariamente lesivos aos interesses dos outros sócios, concluindo-se, portanto que a tutela em exame é aplicável apenas nos casos em que a deliberação não tenha uma própria e autônoma justificação baseada nos interesses legítimos dos sócios majoritários e a finalidade fraudulenta de dano da minoria constitua a única razão da deliberação, restando vedada, fora de tais hipóteses, qualquer possibilidade de intervenção em sede judiciária sobre os motivos que tenham induzido os majoritários a adotar a deliberação, constituindo, evidentemente, ônus de quem impugna a deliberação, de demonstrar a efetiva ocorrência do abuso ou do excesso (Cass. 19.4.2003, n.6361, FI, I, 1219. Conf. Cass. 5.5.1995, n.4923, Soc. 1995, 1548; Cass. 4.5.1994, n. 4323, FI 1995, I, 2219; Cass. 11.3.1993, n.2958, RFI 1993, voce Società, n. 498)."243

Verificado o abuso no exercício do poder de controle, é necessário, ainda, demonstrar os prejuízos causados pelo controlador, à sociedade e aos demais acionistas o que nem sempre é possível ou de fácil determinação ${ }^{244}$.

A determinação de quais são os interesses externos merecedores dessa proteção foi deixada, como se viu acima, para definição da doutrina e

\footnotetext{
${ }^{242}$ PENTEADO, Mauro Rodrigues. Aumentos de Capital..., pág. 271.

${ }^{243}$ TERRUSI, Francesco L'Invalidità..., pág. 145.

${ }^{244}$ REsp 798.262, j. 06.02.2007, $3^{\mathrm{a}}$ Turma, Relatora Ministra Nancy Andrighi, maioria: "Recurso Especial. Direito Processual Civil e Direito Societário. Art. 117, § 1. ${ }^{\circ}$, da lei n. ${ }^{\circ}$ 6.404/76 (lei das sociedades). Modalidades de abuso de poder de acionista controlador. Forma exemplificativa. Caracterização do abuso de poder. Prova do dano. Precedente. Montante do dano causado pelo abuso de poder do acionista controlador. Fixação em liquidação de sentença. Possibilidade.(...) Para a caracterizacão do abuso de poder de que trata o art. 117 da Lei das Sociedades por acões, ainda que desnecessária a prova da intenção subjetiva do acionista controlador em prejudicar a companhia ou os minoritários, é indispensável a prova do dano. Precedente." (Grifo nosso).
} 
jurisprudência, como forma de flexibilizar a determinação de quais são esses interesses protegidos, no caso concreto.

A falta de previsão legal expressa definindo os titulares dos interesses externos protegidos e ainda o tipo de ação a ser ajuizada é, para muitos doutrinadores, um dos motivos pelos quais essa proteção não possui eficácia e impede a construção de jurisprudência a respeito no Brasil. ${ }^{245}$

O controlador tem deveres para com os acionistas minoritários e o principal deles é que, no exercício do poder de controle, ele deve agir com boa-fé e lealdade para os demais acionistas. Por esse motivo, ocorrendo abuso do controlador, ainda que o interesse social não seja afetado, sendo indiferente, para a companhia, o resultado da decisão tomada, se comprovado que a objetivo da medida tomada foi prejudicar os acionistas minoritários, a decisão poderá ser anulada ${ }^{246}$.

É justamente esse conflito que a lei reconhece e regula mas a definição do interesse social, protegido pelas regras de conflito de interesses e de abuso de direito de voto ou de controle, não se encontra e não poderia se encontrar na lei e depende da análise do caso concreto.

$\mathrm{Na}$ análise da situação concreta, a determinação da solução aplicável aos casos de abuso de poder ou de direito de voto, deve ser considerada não

245 Nesse sentido, COMPARATO, Fábio Konder, O Poder de Controle..., pág 371: "Ora, essa clara afirmação da supremacia dos interesses comunitários e nacionais, quando em conflito com o escopo lucrativo da companhia, aparece em nosso direito despida do necessário aparelhamento de aplicação e eficácia. Cedemos aí, mais uma vez, à tradição jusnaturalista, de puras afirmações de princípio, sem o necessário complemento dos remédios jurídicos sancionatórios. Pois, se o titular desses interesses comunitários e nacionais transborda largamente o círculo empresarial, quem tomará a iniciativa de defendê-los e com que tipo de ação? Certamente não os acionistas, mesmo minoritários ou nãocontroladores. Na formulação legal do mecanismo da responsabilidade civil, houve a definição de novos interesses protegidos e de novo responsável (o controlador), ao lado dos administradores. Mas não houve a indispensável designação do agente legimitado a agir em prol do bem público."

${ }^{246}$ HALPERIN, Isaac e OTAEGUI, Julio C. Sociedades Anónimas..., pág. 224: "La noción de que el interés social es el interés común de todos los sócios - y que los derechos para hacerlo valer deben ser ejercidos com lealtad y entendidos de buena fé - torna ilícita la decisión de la mayoría, que si no perjudica a la sociedad, no beneficia a todos los sócios (siempre habrá uma uma lesón al interés social). (...) El interés social exige que la decisión se adopte para fines sociales y em interés general de la sociedad, que no se respetarán cuando decisiones acordes com el interés social se realizan em fraude de la minoria (...) y em violación de la lealtad y de la buena fé, que son los presupuestos de los remédios técnicos que inspiran el régimen mayoritario. La solución abusiva se anula, com responsabilidad de los accionistas (art. 254).” (Grifos no original). 
apenas a situação da sociedade isoladamente, mas a sua participação, se for o caso, em um grupo de sociedades, o que acarreta uma alteração na disciplina e fiscalização do abuso de poder de controle, conforme determinado nos artigos 245, 246, 266 e 276 da Lei das S.A.

Por princípio, a existência de personalidade jurídica própria e de patrimônio independente de uma sociedade acarreta a seus controladores e administradores a obrigação de perseguir e proteger os interesses desse novo ente. $\mathrm{O}$ reconhecimento da personalidade jurídica e interesses distintos de cada sociedade, ainda que sob o mesmo controle, exige que nos negócios realizados com sociedades controladas ou coligadas, quando existem minoritários nessas companhias, sejam observadas as regras de mercado para preservação dos interesses das sociedades contratantes de forma a não acarretar prejuízo para uma parte, em favorecimento de outra.

Nos grupos de direito, assim compreendidos os grupos de sociedades que tenham formalizado uma Convenção de Grupo, com o estabelecimento de regras de divisão de receitas, despesas e responsabilidades e a estrutura administrativa, poderá ser determinada a subordinação de interesses entre as sociedades participantes do Grupo e essas regras passam a oponíveis a terceiros e aos acionistas minoritários das sociedades integrantes do Grupo. Como na criação de um Grupo de sociedades, os interesses de uma ou mais companhias poderão ser sacrificados ou subordinados aos interesses de outra(s), alterando assim, substancialmente, a natureza da sociedade que terá seus interesses subordinados, a participação de uma companhia em um Grupo de sociedades formalmente constituído, consta do rol dos atos que geram direito de retirada a acionistas minoritários (art. 136, V).

Nos grupos de fato, isto é, nas sociedades que estão sob controle comum ou nas sociedades coligadas nas quais não houve formalização de uma Convenção de Grupo (e que são a maioria das situações em nosso país), não há esse regramento explícito e, portanto, os atos praticados pelos administradores, se beneficiarem uma sociedade, em prejuízo da companhia em que atuam, não estão respaldados e justificados expressamente na Convenção do Grupo, aceitas pelos acionistas da companhia prejudicada e podem acarretar a responsabilidade pessoal do 
administrador e o dever de reparar os danos e prejuízos causados, nos termos do art. 245 .

Os prejuízos causados a uma sociedade ou a seus acionistas minoritários, em razão da realização de operação que beneficie empresa controladora ou coligada, se não estiverem de acordo com as disposições da Convenção de Grupo aprovada, devem ser ressarcidos pelo acionista controlador. Para isso, os artigos 246 e 276 legitimam os sócios minoritários, detentores de, pelo menos 5\% do capital social, ou qualquer acionista, independemente de sua participação, desde que preste caução das custas e sucumbência da ação, a ajuizar ação contra os administradores e a sociedade controladora do Grupo e garante ao autor da ação, em caso de sucesso, prêmio no montante de $5 \%$ do valor da ação.

O art. 2409 do Código Civil Italiano, anteriormente comentado, prevê expressamente a intervenção judicial na administração e funcionamento das sociedades por ações, no caso de fundamentada suspeita de graves irregularidades que possam afetar o correto funcionamento da sociedade ou dos grupos de sociedades.

Inicialmente, o art. 2409 não previa expressamente a possibilidade de intervenção judicial nos casos envolvendo Grupos de sociedades. Em 2003, com a reforma da legislação societária na Itália, esse dispositivo foi modificado, com base na experiência dos tribunais italianos e passou a prever a utilização desse instituto, no caso de suspeita de grave irregularidade que prejudique sociedade controlada.

Ainda em relação à tutela dos interesses externos à companhia, se verifica, em muitos casos, a existência de Grupos de sociedades, de fato ou de direito, formados para facilitar a transferência de patrimônio entre as empresas e destas ao seu controlador final, prejudicando credores.

Os tribunais brasileiros, antes mesmo da entrada em vigor do atual Código Civil em 2003, já aplicavam de forma pacífica, em caso de utilização fraudulenta de uma ou mais sociedades, com o intuito de prejudicar terceiros, a desconsideração da personalidade jurídica das sociedades envolvidas, para 
determinação do beneficiário último das operações realizadas pelas empresas e ressarcimento dos terceiros prejudicados, como se pode verificar no Acórdão proferido pela $3^{\mathrm{a}}$ Turma do STJ, no julgamento do Recurso Especial no 332.763, em 30.04.2002 ${ }^{247}$ : "Processual Civil. Recurso especial. Ação de embargos do devedor à execução. Acórdão. Revelia. Efeitos. Grupo de sociedades. Estrutura meramente formal. Administração sob unidade gerencial laboral e patrimonial. Gestão fraudulenta. Desconsideração da personalidade jurídica da pessoa jurídica devedora. Extensão dos efeitos ao sócio majoritário e às demais sociedades do grupo. Possibilidade. (...) Havendo gestão fraudulenta e pertencendo a pessoa jurídica devedora a grupo de sociedades sob o mesmo controle e com estrutura meramente formal, o que ocorre quando as diversas pessoas jurídicas do grupo exercem suas atividades sob unidade gerencial, laboral e patrimonial é legitima a desconsideração da personalidade jurídica da devedora para que os efeitos da execução alcancem as demais sociedades do grupo e os bens do sócio majoritário. - Impedir a desconsideração da personalidade jurídica nesta hipótese implicaria prestigiar a fraude à lei ou contra credores. - A aplicação da teoria da desconsideração da personalidade jurídica dispensa a propositura de ação autônoma para tal. Verificados os pressupostos de sua incidência, poderá o Juiz, incidentemente no próprio processo de execução (singular ou coletivo), levantar o véu da personalidade jurídica para que o ato de expropriação atinja os bens particulares de seus sócios, de forma a impedir a concretização de fraude à lei ou contra terceiros." 248

A eficácia da medida, com a responsabilização do controlador que agiu de forma abusiva, depende da identificação do efetivo controlador daquela sociedade e, nos casos de Grupos de sociedades, em que é criada uma estrutura complexa para exercício do poder de controle, com utilização de várias pessoas jurídicas, o responsável pelo exercício do controle normalmente não é a sociedade que diretamente proferiu o voto mas outra que a controla e que determinou os rumos que os negócios das sociedades integrantes do grupo devem tomar.

\footnotetext{
${ }^{247}$ Relatora Ministra Nancy Andrighi, v.u.

${ }^{248}$ Também nesta linha, COMPARATO, Fábio Konder. $O$ Poder de Controle..., pág. 450: “A confusão patrimonial entre controlador e sociedade controlada é, portanto, o critério fundamental para a desconsideração da personalidade jurídica externa corporis. E compreende-se, facilmente, que assim seja, pois, em matéria empresarial, a pessoa jurídica nada mais é do que uma técnica de separação patrimonial. Se o controlador, que é o maior interessado na manutenção desse princípio, descumpre-o na prática, não se vê bem porque os juízes deveriam respeitá-lo, transformando-o, destarte, numa regra puramente unilateral."
} 
Tem-se assim, a figura do controlador indireto, que exerce o controle através de diversas sociedades, coligadas e controladas, que figuram nos livros societários como titulares do capital suficiente para a tomada das principais decisões da sociedade, mas que, no entanto, exercem esse controle sob determinação da sociedade ou do sócio titular do controle através dessa rede de sociedades.

\section{Alfredo Lamy Filho e José Luiz Bulhões Pedreira ${ }^{249}$ assim} conceituaram esse tipo de controle típico dos grupos societários: "Controle indireto é modalidade de poder própria de um grupo ou estrutura de sociedades. A relação de poder não é parte da organização interna de uma das sociedades, mas do grupo, pois vincula o papel de acionista controlador de uma sociedade aos órgãos sociais de outra. A fonte do poder são as relações societárias entre as sociedades, e o poder é exercido indiretamente - através dos órgãos sociais de outra sociedade"250.

\footnotetext{
${ }^{249}$ A Lei das S.A.... vol. 2, pág. 625.

250 A legislação alemã determina expressamente que, nos grupos de fato, a sociedade controladora somente será diretamente responsável pelos danos individualmente causados a um acionista minoritário, se esses danos não refletirem apenas na diminuição do valor de suas ações, em razão dos prejuízos causados à companhia, conforme pesquisa de CONAC, Pierre-Henri, ENRIQUES, Luca e GELTER, Martin. Constraining Dominant..., pág. 23: "Finally, in the context of corporate law, the German law on de facto groups explicitly stipulates that the controlling entity is directly liable to minority shareholders if these incurred an individual damage that does not just reflect a lower share value because of a damage to the company."
} 


\section{IV.4 - INOBSERVÂNCIA DOS DEVERES DOS ADMINISTRADORES}

Os artigos 153 a 157 da Lei das S.A. estabelecem os deveres a que estão subordinados os administradores de companhias (incluindo membros do Conselho de Administração, do Conselho Fiscal e da Diretoria) e seus controladores, no exercício de suas atribuições e que são fundamentalmente divididos entre: (a) dever de diligência, (b) dever de lealdade e (c) dever de informar.

O legislador brasileiro optou por estabelecer estes princípios gerais que regulam a atuação dos administradores, determinando ainda algumas das hipóteses concretas em que estes estarão impedidos de atuar ou deverão ser responsabilizados por agir em desacordo com os deveres impostos pela lei, conforme previsto nos arts. 154, 156, 245 e 276 da Lei das S.A., que estabelecem hipóteses de ocorrência de conflitos de interesses ou abuso de poder que acarretarão aos administradores responsabilidade pessoal pelos atos por eles praticados em prejuízo da companhia.

Os padrões de conduta estabelecidos nesses artigos, acompanhando o sistema utilizado pelos autores da Lei das S.A., são amplos e conferem aos tribunais a obrigação de interpretá-los, em cada caso específico, de acordo com os princípios que regem as sociedades por ações e as especificidades do caso concreto ${ }^{251}$.

${ }^{251}$ ZANINI, Carlos Klein. A Doutrina dos “Fiduciary Duties”..., pág. 139, comentando a dificuldade encontrada na jurisprudência norte-americana para definir a abrangência dos deveres de lealdade e diligência impostos aos administradores, constata: "No Direito Brasileiro, por sua vez, tais dificuldades se repetem, sendo ainda agravadas em função da escassa elaboração doutrinária e, principalmente, jurisprudencial, sobre tais conceitos empregados na legislação. Desnecessário referir, neste sentido, que sabe-se muito pouco sobre a extensão e alcance do standard empregado por nossa lei de sociedades por ações ao regrar o dever de diligência, quando impõe ao administrador 'no exercício de suas funções, o cuidado e diligência que todo homem ativo e probo costuma empregar na administração dos seus próprios negócios." " 
Regra geral, o administrador não é pessoalmente responsável pelas obrigações que contrair em nome da sociedade e em virtude de ato regular de gestão, dentro de suas atribuições ou poderes ${ }^{252}$. A responsabilização pessoal do administrador depende da comprovação de violação aos deveres de lealdade, de informação ou de diligência a que estão obrigados para a companhia e seus acionistas.

O objeto social da companhia estabelece os limites dentro dos quais os administradores possuem autonomia para agir, dentro dos interesses da sociedade $^{253}$, conforme artigo 154 da Lei das S.A. Na sua atuação, devem ainda atender aos princípios de lealdade e boa-fé que são princípios gerais ao Direito Privado, que regem os negócios jurídicos em geral.

A eleição dos primeiros administradores da companhia já lhes atribui a responsabilidade pela realização dos procedimentos de arquivamento e publicação dos atos constitutivos, no prazo de 30 dias contados da realização da Assembléia Geral ou da assinatura da escritura pública de constituição, conforme artigo 99 da Lei das S.A., necessários para que a companhia adquira personalidade jurídica e patrimônio próprios. O atraso no arquivamento e publicação dos atos constitutivos, torna os administradores solidariamente responsáveis com a companhia, pelos atos por eles praticados, a menos que a Assembléia Geral de sócios decida em sentido contrário.

Não se pode criticar a penalidade determinada pela legislação brasileira para descumprimento da obrigação de arquivamento e publicação dos atos constitutivos da companhia, considerando que, enquanto não finalizados os procedimentos para sua constituição, esta não adquire personalidade jurídica própria e, portanto, não se forma o patrimônio autônomo da sociedade que responderá pelas obrigações por ela contraídas permanecendo os acionistas solidariamente responsáveis

${ }^{252}$ Conforme art. 49 do Código Civil e arts. 153 e 158 da Lei das S.A.

${ }^{253}$ ZANINI, Carlos Klein. A Doutrina dos "Fiduciary Duties" ..., pág. 138: "Sendo o objeto social uma previsão das atividades que a companhia deve desenvolver, resta claro que os administradores desta sociedade têm o dever legal de orientar sua atuação à frente da administração de modo a conduzir a companhia para atingimento das finalidades estatutariamente previstas. A obediência ao objeto social exigida dos administradores tutela, em última análise, os interesses dos acionistas, cuja inversão de capital pessoal na sociedade deu-se para a consecução das atividades sociais no estatuto descritas, não dispondo o administrador de autonomia suficiente para, sponte sua, eleger os caminhos que serão trilhados pela empresa por ele gerenciada." 
pelas obrigações contraídas pela sociedade e pelos atos praticados em seu nome, até a regularização da sociedade.

O objetivo dos sócios, ao constituir uma companhia é justamente desenvolver as atividades empresariais e obter os lucros daí decorrentes, limitando suas responsabilidades aos montantes por eles aportados na companhia e sem o risco de terem seus patrimônios atingidos pelas obrigações sociais, desde que atuem dentro dos parâmetros legais e estatutários.

A Itália possui dispositivo semelhante (art. 2.332) e a doutrina também defende essa solução, ainda que de forma não unânime, como se pode verificar na colocação feita por Vincenzo Vitró ${ }^{254}$ : "Se a estrutura societária é o instrumento, escolhido pelos sócios para realizar a livre iniciativa econômica (art. 41 da Constituição), e este reconhecimento tutela os direitos dos sócios, os quais decidem correr o risco da empresa, na forma societária, para limitar, aos valores conferidos, sua responsabilidade patrimonial, a previsão da responsabilidade dos administradores pela falta do depósito do ato constitutivo tutela os sócios sob o aspecto da assunção de responsabilidade ilimitada pela falta de reconhecimento da personalidade jurídica; e portanto tal norma não é uma "norma estranhíssima" como ao contrário opina Cipriani, objetivando advertir os administradores para o adimplemento de seus deveres derivados do contrato de sociedade."

A recente reforma do Código Civil Italiano, levada a termo pelo Decreto Legislativo $\mathrm{n}^{\circ}$ 06, de 22 de janeiro de 2003 introduziu várias modificações na estrutura da administração das sociedades por ações, algumas delas acompanhando as diretivas para modificação da legislação societária da Comunidade Econômica Européia, inclusive quanto às responsabilidades dos administradores e possibilidade de intervenção judicial nas sociedades.

${ }^{254}$ Procedimento Camerali, Omologa e Nullitá delle Societá per Azioni, pág. 374: "Se la struttura sociale è lo strumento, scelto dai soci per realizzare la libera iniziativa economica (art. 41 Cost.), e il riconoscimento tutela i diritti dei soci, i quali decidono di correr il rischio d'impresa in forma societária, per limitare ai conferimenti la responsabilitá patrimoniale, la previsione della responsabilitá degli amministratori per mancato deposito dell'atto costitutivo tutela i soci sotto il profilo dell'assunzione della responsabilitá illimitata per mancato riconoscimento della personalitá giuridica; e pertanto tale norma non é "norma stranissima"como invece opina Cipriani, atteso che essa richiama gli ammnistratori all'ademimento di doveri che devirano dal contratto di societá." 
Por grave irregularidade cometida pela administração, que justifique a intervenção judicial em uma sociedade por ações, nos termos do art. 2409 do Código Civil, os tribunais italianos concluíram ${ }^{255}$ : "De modo esquemático e sintético, se pode dizer que a grave irregularidade que justifica a instauração do procedimento nos termos do art. 2409 do Código Civil são os atos ou as omissões graves que desacreditam a sociedade externamente e vulneram, internamente, a relação de confiança que une os administradores e os fiscais aos sócios (Corte de Cassação, 15.05.1972)."

Conforme estudo de Carlos Klein Zanini ${ }^{256}$, inicialmente apenas os administradores das companhias estavam obrigados a observar os deveres de lealdade, diligência e de obrigatoriedade de atuação dentro do objeto social, denominados, no direito norte-americano de fiduciary duties. Com o desenvolvimento do entendimento dos tribunais, a jurisprudência estendeu a aplicação desses princípios também aos controladores das companhias de capital fechado, aplicando as especificidades desses deveres aos controladores das close corporations e concluindo atualmente que a violação dos deveres de lealdade dos controladores, ocasiona uma situação de opressão para os minoritários.

Comentando o artigo 156 da Lei das S.A., que trata da interferência de administrador com interesse conflitante com o da companhia, Frederico Augusto Monte Simionato ${ }^{257}$ conclui que o interesse do administrador deve ser analisado de acordo com sua natureza e sua extensão, sendo a natureza "...entendida como a razão maior do conflito, ou seja, aquilo que está determinando o impedimento. (...) a causa que origina a incompatibilidade de interesses, ao passo que a extensão do interesse é certamente indefinível. Um interesse não é mais ou menos extensível para

${ }^{255}$ QUATRARO, Bartolomeo e TOSI, Emilio. Il Controllo Giudiziario..., pág. 309: "In modo schematico e sintético, si può dire che le gravi irregolarità che giustificano l'instaurazione del procedimento ex art. 2409 c.c. sono gli atti o le omissioni gravi che screditano la società all'esterno o vulnerano, all'interno, il rapporto di fiducia che lega gli amministratori ed i sindaci ai soci (cosi Cass., 15 maggi 1972, n. 1530)."

${ }^{256}$ A Doutrina dos "Fiduciary Duties"..., pág. 142: “Assim, passa-se a exigir, principalmente nas sociedades anônimas de capital fechado (close corporations), que os fiduciary duties sejam observados não apenas no sentido de não causar prejuízo à companhia, mas, também, aos acionistas minoritários. Exemplo característico disto tem-se com o desenvolvimento da teoria da oppression of the minorities shareholders by the majority, a qual reconhece, servindo-se de outro conceito de excepcional importância na common law - o de reasonable expectations -, a existência de expectativas rasoáveis por parte dos acionistas minoritários de uma sociedade anônima fechada que merecem ser atendidas."

${ }^{257}$ Sociedades Anônimas ..., pág. 101. 
impedir uma negociação, nem comporta quantificação. Nesse caso, o antagonismo do conflito de interesses está na precisa determinação daquilo que impede a negociação, ou seja, a prática contrária aos deveres dos administradores (principalmente os deveres de diligência e lealdade)."

Pierre-Henri Conac, Luca Enriques e Martin Gelter ${ }^{258}$, analisando a legislação e jurisprudência da França, Alemanha e Itália, concluem que nos três países existem princípios que restringem a liberdade dos administradores em administrar a empresa no interesse apenas dos controladores, em atendimento ao dever de lealdade com a companhia e os demais acionistas que exige que eles revelem e até mesmo se oponham ao acionista controlador em suas tentativas de abusar do poder de controle em benefício próprio.

Esses autores ressaltam ainda que, de acordo com a legislação Italiana e Francesa, as ações que versam sobre a responsabilidade dos administradores podem ser ajuizadas não apenas contra os administradores formalmente eleitos, mas também contra qualquer um que possa ser considerado como administrador "de fato" da companhia, que influencie as decisões dos administradores, como é o caso dos acionistas controladores ${ }^{259}$.

Outro aspecto da responsabilidade dos administradores, relacionado aos deveres de lealdade com a companhia e com todos os acionistas, se traduz na obrigação de impugnar eventuais deliberações tomadas pelos demais administradores ou acionistas que sejam contrárias ao interesse da sociedade e causem prejuízo a esta última. Tal responsabilidade assume maior relevância quando se trata da aprovação das demonstrações financeiras e do balanço da empresa. Os administradores não apenas têm acesso a informações, mas têm a obrigação de acompanhar o andamento

\footnotetext{
${ }^{258}$ Constraining Dominant..., pág. 12: "In all three jurisdictions, standards are in place that restrict directors' ability to manage the company in the interest of dominant shareholders alone and the ability of dominant shareholders themselves to exercise control powers to the detriment of other shareholders. First, legal scholars and courts hold that directors in all countries owe their company a duty of loyalty that require them to disregard or even oppose dominant shareholders' attempts to self-deal."

${ }^{259}$ Constraining Dominant..., pág. 21: "However, under Italian and French laws, liability suits can be brought not only against directors formally elected, but also toward anyone de facto managing the company by exercising powers that are typical of a director, like presiding over board meetings, individually making the main company's decisions, and so on. Typically, this can be the case of a dominant shareholder."
} 
dos negócios da sociedade e sua real situação econômica e contábil e têm o dever e a responsabilidade de manter os controles legais para que a real situação da companhia e de seus negócios seja conhecida pelos acionistas.

As consequiências negativas que a aprovação de demonstrações financeiras e do balanço da companhia em desacordo com a realidade ou que uma deliberação ilegítima baseada em documentos e informações que estão em desacordo com a realidade, podem se projetar por vários exercícios e afetar vários atos praticados pela companhia. Desta forma, ainda que o administrador ou conselheiro fiscal tenha sido eleito posteriormente à aprovação de tais documentos, ao tomar conhecimento dessas irregularidades, o administrador deve avaliar o fato e os prejuízos causados à companhia, a terceiros e aos acionistas minoritários e denunciá-lo à Assembléia, tomando a iniciativa para anular o ato ilegítimo, sob pena de responder solidariamente pelos prejuízos causados, como determina os parágrafos $1^{\circ}, 2^{\circ}$ e $4^{\circ}$ do artigo $158^{260}$.

A legitimidade da representação e inexistência de conflito de interesse entre representante e a pessoa jurídica por ele representada é essencial para preservação dos interesses desta última. Como a pessoa jurídica somente pode praticar atos através de uma pessoa física, a representação desta somente pode ser exercida no interesse exclusivo da sociedade. Como ressaltou Waldemar Ferreira ${ }^{261}$, "A vontade do representado é aí a própria vontade do representante, a qual, necessária e obrigatoriamente, tal qual a lei a concebe, deve orientar-se sempre e indeclinavelmente no interesse do representado."

\footnotetext{
${ }^{260}$ A doutrina e jurisprudência italiana, é pacífica nesse sentido, conforme apontado por TERRUSI, Francesco. L'Invalidità..., pág. 182: "Nel senso che l'obbligatorietà dell'impugnativa esclusivamente si appunta sul (e si commisura al) dovere di intervento finalizzato a impedire atti pregiudizievoli per la società (cfr. Calandra Buonaura 1985, 209 e seg; Colombo 1965, 408 e seg.; Scorza 1963, 510 e seg.). In questa direzione rimane ancora oggi persuasiva l'affermazione, sulla quale si registrano i maggiori consensi (cfr. Spunti Cass. 29.8.2003, n. 12696, FI 2004, I, 3176), che l'impugnazione degli organi ammnistrativi e di controllo rientra nel mantenuto dovere di perseguire, in siffatti termini, l'interesse sociale (Oppo 1957, 228; Galgano 1988-a, 68), finanche quale fondamento unitário della responsabilità di cui agli artt. 2392 e seg. e 2403 c.c., non avendo, ammnistratori, sindaci e consiglieri di sorveglianza, a questo riguardo, propri interessi disponibili da tutelare a mezzo dell'azione (cfr. Anche Jaeger 1963, 171, che, peraltro, sembra legar la legittimazione di ammnistratori e sindaci alla necessità di tutela delle minoranze). Va quindi precisato che l'obbligatorietà costituice corollario dei doveri dei ridetti organi rispetto alle sole deliberazioni dannose per la società (così giustamente Zanarone 1993, 266), con consequenziale esclusione, in concreto, dell'obbligo di esercizio dell'azione nel caso di vizio di uma deliberazione che non sai atale da rappresentare, in sè, l'insorgenza di um pregiudizio."

${ }^{261}$ O Direito Insurrecional..., pág. 96.
} 
A prática de um ato, no qual o representante de uma companhia sacrifica interesses desta última em benefício próprio configura um verdadeiro "autocontrato", que é vedado pela nossa legislação, na medida em que elimina o consenso na construção do vínculo obrigacional, sobrepondo-se o interesse do representante ao da companhia, que é, também, o mesmo interesse daquele com quem a companhia contrata. Com o sacrifício do interesse da companhia na prática desse ato, tem-se, na verdade, um único interesse de ambos os lados, o do representante, o que é vedado pelos artigos 117 e 119 do Código Civil por configurar hipótese de contrato consigo mesmo.

A ação de responsabilidade civil contra o administrador, pelos prejuízos por ele causados ao patrimônio da companhia está prevista no art. 159 da Lei das S.A. Essa ação compete, inicialmente, à companhia, mediante prévia deliberação da Assembléia Geral (ação "ut universi”, que versa sobre um dano causado diretamente à companhia). Se a Assembléia Geral aprovar o ajuizamento da ação, mas não a companhia não tomar a iniciativa de promovê-la em até 3 meses da Assembléia, qualquer acionista poderá ajuizar a ação; da mesma forma, se a Assembléia Geral deliberar não promover a ação, os acionistas representando, no mínimo, 5\% do capital social poderão ajuíza-la. Em ambos os casos trata-se de ação social "ut singuli" em que o acionista minoritário ingressa em juízo na defesa do patrimônio social, constituindo verdadeiro órgão social ${ }^{262}$. Nos casos em que a ação for movida por um acionista, tenha ou não a Assembléia aprovado essa decisão, os resultados da ação reverterão para a companhia, que será ressarcida dos prejuízos causados pelo administrador, ressarcindo o acionista autor da ação das despesas por ele incorridas.

A Assembléia Geral é o órgão soberano para determinação dos rumos da sociedade e também fiscaliza o cumprimento dos deveres e a atuação dos administradores. Anualmente, na Assembléia Geral Ordinária, os resultados do exercício o relatório das atividades da companhia demonstram a regularidade dos atos de gestão e servem para avaliar o desempenho dos administradores. Em caso de ocorrência de irregularidades ou em se verificando que um administrador não está

${ }^{262}$ CARVALHOSA, Modesto. Comentários..., vol. 3, págs. 335 e 336. 
preparado para o cargo que ocupa ou não atende às expectativas dos acionistas, estes podem destituí-lo, a qualquer tempo.

Independentemente da possibilidade de ajuizamento de ação, pela companhia, diretamente, se aprovado pela Assembléia Geral, ou através de acionista, agindo individualmente, para preservação de interesse próprio e não da sociedade, como no caso das ações "ut singuli", o $§ 7^{\circ}$ do art. 159 prevê a possibilidade de acionistas acionarem diretamente o administrador de uma companhia, se tiverem sido diretamente prejudicados pelos atos do administrador como, por exemplo, nos casos em que o administrador não divulga ao mercado informações relevantes que seriam decisivas para a decisão do acionista adquirir ou não ações ou valores mobiliários daquela companhia ${ }^{263}$. Por danos diretamente causados ao acionista, por um ato praticado pelo administrador, não estão incluídos os prejuízos decorrentes da desvalorização das ações daquele acionista, por diminuição do patrimônio da companhia, pois esse é um dano que todos os acionistas sofrem em caso de ilegalidade de atos dos administradores e a ação, nesse caso, cabe à companhia, diretamente prejudicada, ainda que venha a ser ajuizada pelos acionistas minoritários (ação "ut singuli").

Em qualquer um dos casos em questão, o administrador somente será responsável pelos atos que praticar em desobediência aos deveres impostos no art. 153 e seguintes. Ainda que a administração da companhia, como um todo, ou o resultado de um ato isolado praticado pelo administrador, produza efeitos negativos para a companhia ou seus acionistas, o juiz poderá, nos termos do $\S 6^{\circ}$ do art. 159 , excluir a responsabilidade pessoal do administrador, se convencido que este agiu de boa-fé e visando ao interesse da companhia.

\footnotetext{
${ }^{263}$ Modesto Carvalho, em Comentários..., vol. 3, págs. 338 e 339 ressalta a dificuldade de se distinguir entre a ação social e a ação individual, antevendo as hipóteses em que o acionista é prejudicado pelo uso de informações confidenciais da companhia que manipulem as cotações do mercado, em detrimento dos direitos de negociação em igualdade de condições com os demais acionistas; no caso do administrador se recusar a prestar as certidões requeridas nos termos do art. 100; quando o administrador crie dificuldades e formalidades abusivas para o pagamento de dividendos declarados; se existir uma relação direta entre o acionista e o administrador (que, por exemplo, é seu procurador para uma Assembléia) ou ainda se o administrador agiu de má-fé e superavaliou os patrimônios líquidos das companhias envolvidas em incorporação, fusão ou cisão.
} 


\title{
IV.5 - A REGRA DE JULGAMENTO DO NEGÓCIO ("BUSINESS JUDGMENT RULE")
}

\begin{abstract}
Reconhecida a importância da proteção de certos interesses internos e externos à companhia, para realização de suas atividades, como limitadores ao exercício do poder de controle e o potencial conflito que pode surgir da condução dos negócios sociais, pelos controladores, foram desenvolvidos mecanismos de defesa e proteção aos interesses internos e externos, contra atos abusivos ou realizados em conflito de interesses pelos administradores e controladores da companhia.
\end{abstract}

Assim, considerando que o objetivo dos acionistas, na constituição da companhia, é juntar esforços para possibilitar a realização de uma ou mais atividades, previamente estabelecidas no Estatuto Social, com a limitação de suas responsabilidades patrimoniais e que, a forma mais eficiente de se conduzir os negócios sociais, após a constituição da sociedade, é através de deliberações tomadas pela maioria, é de fundamental importância para preservação dos princípios que regem as sociedades por ações, que se estabeleçam regras dentro das quais o poder de controle não sirva de instrumento para prejudicar a própria companhia ou os acionistas minoritários, ou ainda para obter benefícios pessoais.

Por outro lado, esse controle ao poder de controle não pode impedir ou criar limitações de tal espécie que estabeleçam obstáculos ao controlador e administradores da companhia, para tomar as decisões que entendam mais convenientes e interessantes à sociedade, com receio de que, caso tais decisões se revelem, no futuro, incorretas ou acarretem prejuízos à sociedade, sejam pessoalmente responsabilizados pelos prejuízos causados.

Isto significa dizer que, a administração dos negócios sociais da companhia deve sempre buscar o interesse desta e, em última instância, de seus sócios, 
tendo como limites os interesses públicos externos à sociedade. Para isso a realização dos negócios sociais, os controladores e administradores da companhia diariamente tomam decisões que influenciam, direta ou indiretamente, os resultados da companhia. Diversos fatores determinam os resultados dessas decisões, fatores internos (como a capacidade de produção da companhia, desenvolvimento de tecnologias para atender à demanda de novos produtos ou serviços, realização de investimentos) e fatores externos (crises financeiras, ocorrência de greves, interrupção de fornecimento de matéria-prima ou diminuição da demanda pelos produtos ou serviços oferecidos, disponibilidade e custo do crédito no mercado).

No momento em que uma decisão é tomada pelo administrador ou controlador, ele pode ter acesso a informações que indiquem qual será o resultado de sua decisão, em razão da conjunção de todos esses fatores, internos e externos.

Muitas vezes, no entanto, não é possível prever todas essas situações, e uma decisão que dentro do cenário em que foi tomada traria resultados positivos à companhia, pode se revelar desastrosa e trazer graves danos à companhia e seus acionistas.

Atualmente, em razão da globalização da economia, o resultado das empresas no mundo inteiro é afetado por crises econômicas, escassez ou abundância de materiais, aumento ou diminuição da demanda, ainda que os fatores que levaram a essas crises e alterações no mercado, não tenham ocorrido diretamente nos países em que as empresas estão sediadas ou não ocorram diretamente no mercado em que atuam.

Por esses motivos, nos dias de hoje, o processo decisório de uma companhia, exige muito mais informações e é muito mais complexo do que há 30, 40 anos atrás em razão da abundância de informações disponíveis e da necessidade de avaliar seu conteúdo, os impactos que causarão à empresa e os diversos cenários econômicos que poderão afetar o resultado da companhia. Para se prevenir de responsabilidades e aproveitar as melhores oportunidades para a companhia, os controladores e administradores precisam não apenas obter o máximo de informações possíveis, mas também saber interpretá-las e, para isso, muitas vezes é necessário o auxílio de analistas de mercado e consultores independentes. 
A necessidade de contratação de mais profissionais, pela companhia, e de profissionais externos, encarregados de realizar essa análise de mercado e de prestar assessoria à administração na tomada de decisões aumenta os custos da empresa. E esses custos são repassados, ainda que indiretamente, a todos os acionistas, na medida em que as despesas da companhia aumentam e, consequentemente, seus resultados diminuem. Por esse motivo, os próprios acionistas podem restringir a contratação de profissionais que poderiam aumentar a segurança na tomada de decisões e permitiriam uma análise mais aprofundada da decisão a ser tomada e suas conseqüências.

No entanto, por mais informados e bem intencionados que os controladores e administradores de uma companhia estejam, nem sempre são alcançados os objetivos pretendidos com uma decisão. O risco do empreendimento é inerente à atividade empresarial e considerando que, muitas vezes, os resultados são proporcionais aos riscos corridos, os empresários estão dispostos a correr maiores riscos para garantir maiores lucros, muitas vezes, por pressão dos próprios acionistas.

Assim, para que a companhia exerça suas atividades de forma competitiva e consiga acompanhar o mercado em que atua, é fundamental a celeridade na tomada de decisões e que as informações disponíveis sejam avaliadas rapidamente, mas ainda que essa avaliação seja feita, é impossível eliminar completamente os riscos de uma decisão.

Responsabilizar direta e pessoalmente os administradores e controladores pelo resultado negativo decorrente de uma decisão empresarial, traria reflexos extremamente prejudiciais para a economia e o ambiente empresarial, na medida em que desestimularia a realização de novos empreendimentos, diminuindo a capacidade do empresário de correr riscos o que afeta diretamente a produtividade das empresas, em um primeiro momento e, em maior escala, a economia em geral $^{264}$.

\footnotetext{
${ }^{264}$ No Brasil, está sendo ampliado o uso de seguros para cobrir os danos causados por atos praticados por administradores. Esses seguros são amplamente utilizados nos Estados Unidos e, atualmente, os administradores, ao aceitar assumir cargo em companhias, normalmente exigem que seja contratado esse seguro para evitar que venham a ser responsabilizados pessoalmente por eventuais prejuízos decorrentes de decisões por eles tomadas na condução dos negócios sociais.
} 
Para que isso não aconteça e, ao mesmo tempo, estejam protegidos os direitos e interesses dos acionistas minoritários e da empresa, contra a utilização desta última, pelo controlador ou administrador, para obtenção de privilégios e vantagens pessoais, um dos maiores desafios do direito empresarial é encontrar o equilíbrio entre esses direitos, deveres e poderes, observados os princípios que regem o direito empresarial e as sociedades por ações.

O grau de proteção conferido por um determinado sistema jurídico, aos direitos dos acionistas minoritários, aos interesses externos à companhia ou à liberdade dos administradores e controladores das empresas vai influenciar a maior ou menor atratividade daquele mercado aos investidores. No entanto, é necessário que o sistema jurídico contemple as situações e problemas que podem ocorrer quando esses direitos e interesses entram em conflito e que as regras para solução dessas situações sejam claras e eficazes, trazendo segurança de sua correta aplicação pelos órgãos de controle administrativo do mercado e pelo Judiciário.

O sistema jurídico norte-americano que tradicionalmente privilegiou os interesses dos empresários, cujos esforços e investimentos foram fundamentais para o desenvolvimento da economia e dos mercados, não apenas desse país, mas também de praticamente todos os demais países que adotam o sistema capitalista e que são afetados pelo andamento da economia norte-americana.

Uma análise superficial da história da economia norte-americana revela essa característica e o papel fundamental que os incentivos à livre iniciativa e à liberdade dos empresários em definir as condições em que exerceriam suas atividades, sem praticamente nenhuma intervenção estatal, tiveram no crescimento da economia norte-americana e na construção das grandes corporações privadas, cujo faturamento pode superar o PIB de alguns países.

Grande parte desse desenvolvimento se deve à facilidade de captar recursos no mercado de capitais, que têm custo inferior aos dos recursos oferecidos pelos bancos, possibilitando a capitalização de empresas para realização de empreendimentos estratégicos e de grande porte. 
A ocorrência de situações em que essa liberdade gerou abusos e causou grandes prejuízos à sociedade em geral, em alguns casos abalando as estruturas do sistema financeiro, aumentou a preocupação Estado e levou à criação de convenções e leis, que permitiram a intervenção no mercado ou aumentaram a vigilância sobre os atos e operações empresariais, a fim de evitar ou diminuir as consequiências dos abusos praticados pelos empresários e os prejuízos causados à economia.

Assim, à medida em que os empresários encontravam oportunidades de mercado e brechas na legislação, que permitam aumentar seus lucros, ainda que em detrimento de seus investidores, o Estado e os tribunais criavam regras para evitar que tais abusos se repetissem e diminuíssem a confiança dos investidores no mercado de capitais.

Os tribunais, dentre eles os de Delaware, considerados o mais especializados em direito empresarial dos Estados Unidos, observando esse cenário, contribuíram para a construção de um sistema de controle dos atos empresariais, através da análise das situações trazidas à sua apreciação que levaram à criação dos princípios e limites aplicáveis à atividade empresarial.

Não obstante a criação de tais regras e princípios limitadores da liberdade empresarial, como medidas de proteção de acionistas minoritários e investidores em geral, a liberdade do empresário conduzir seus negócios, com lealdade e de boa-fé, para obter o máximo de rendimento de seus investimentos, manteve-se como o princípio norteador da atividade empresarial e para análise judicial dos atos empresariais.

A experiência dos tribunais norte-americanos, envolvendo a análise do mérito de decisões tomadas por administradores ${ }^{265}$ e a verificação da inobservância de algum dos deveres impostos a eles para desempenho de suas funções,

\footnotetext{
${ }^{265}$ Ressaltamos que, na legislação norte-americana, ao contrário do que ocorre no Brasil, as decisões principais quanto à condução dos negócios sociais e até mesmo a possibilidade de alteração do Estatuto Social (dentro de certos limites), cabem aos administradores e não à Assembléia Geral de Acionistas, motivo pelo qual a disciplina da Regra do Julgamento do Negócio tem por base principalmente a análise dos atos praticados por administradores, que podem ou não ser acionistas da companhia.
} 
estabeleceu os limites de atuação do Judiciário no âmbito interno das companhias, envolvendo a tomada de decisões empresariais, através da Regra do Julgamento do Negócio ("Business Judgment Rule").

Os parâmetros utilizados pelos tribunais para avaliar se um administrador agiu dentro dos limites de seus poderes legais e estatutários e visando o interesse da companhia, ainda que a decisão não tenha gerado os resultados pretendidos pelos acionistas ou até mesmo tenha causado prejuízos para a companhia, incluem a verificação: (a) se o administrador tomou a decisão devidamente informado e agiu com precaução para obter informações suficientes para avaliar a situação e decidir (ainda que a informação necessária para a tomada da decisão tenha sido fornecida por terceiro contratado pela companhia ou pelo administrador); (b) da boa-fé do administrador; (c) se não houve conflito de interesses na tomada da decisão; (d) se a decisão tomada visou o interesse da companhia; e (e) se não houve abuso de discricionariedade, isto é, arbitrariedade, por parte do administrador. ${ }^{266}$

Lynn A. Stout pondera que a Suprema Corte de Delaware, utilizando os critérios acima referidos, reconheceu que um tribunal não possui a capacidade de determinar o acerto da decisão tomada pelo administrador, porque tem conhecimento das complexidades e incertezas do mundo empresarial e que, sob esta perspectiva, restringe sua análise à verificação da qualidade das informações obtidas e o cuidado no processo de tomada de decisões. ${ }^{267}$

O estabelecimento de limites para a intervenção do Judiciário na impugnação e eventual anulação de decisões tomadas pela administração de uma sociedade é de extrema importância para permitir que a administração de uma sociedade e seus controladores possam tomar as decisões necessárias para a condução dos

\footnotetext{
${ }^{266}$ Nesse sentido, SILVA, Alexandre Couto. A Regra do Julgamento..., pág. 261, consolidando diversas decisões do Estado de Delaware: "São cinco os elementos da regra do julgamento do negócio: a) decisão ou julgamento; b) desinteresse e independência; c) dever de diligência; d) boa-fé; e e) inexistência de abuso de discricionariedade. A regra do julgamento do negócio pressupõe que cada elemento esteja presente e proteja os administradores e suas decisões de uma segunda análise pelo Judiciário."

${ }^{267}$ In Praise of Procedure..., pág. 29: "Acknowledging the complexities and uncertainties of the business world, the Delaware Supreme Court had the wisdom to concede that it was unqualified to sit in judgment on the substantive wisdom of most corporate directors' business decisions. Instead, it focused on what it could judge - the quality and thoroughness of the directors' decision making process."
} 
negócios sociais dentro do ambiente altamente competitivo do mundo empresarial, mas de forma informada e responsável.

Na Itália é aplicado igual princípio, e a doutrina italiana também reconhece que a intervenção judicial na administração das sociedades por ações deve se limitar à verificação da legitimidade das deliberações assembleares, compreendendo a determinação de eventual desvio de finalidade, excesso ou abuso de poder, mas sem avaliar o mérito da deliberação ou controlar os poderes discricionários que a assembléia exerce enquanto órgão soberano da vontade dos sócios ${ }^{268}$.

Os tribunais italianos aplicam expressamente esse princípio, estabelecendo como regra que o juiz não poderá controlar a oportunidade ou a conveniência da solução adotada pela deliberação impugnada, mas deverá verificar que a decisão seja ao menos resultado do legítimo exercício do poder discricionário do órgão deliberante ${ }^{269}$.

A Corte de Cassação Italiana já decidiu que não poderia intervir e anular uma decisão tomada em assembléia, sob a alegação dos acionistas minoritários de que tal decisão seria "irracional", mas não sendo comprovado o excesso de poder e má-fé do acionista majoritário, sob o fundamento que o Judiciário não pode determinar o melhor modo de perseguir o interesse social, o qual é determinado exclusivamente pelos órgãos sociais competentes para tomar as decisões que entenderem convenientes e necessárias para atingir o interesse social ${ }^{270}$.

\footnotetext{
${ }^{268}$ TERRUSI, Francesco. L'Invalidità..., pág. 142: "E difatti, nel suo aspetto pratico, la rilevanza del vizio di (o di ecceso) abuso di potere è strettamente correlata all'estensione del sindacato di legittimità suscettibilie di essere esercitato sul contenuto della deliberazione. Questo perchè, in base a principi assolutamente consolidati, il sindacato dell'autorità giudiziaria sulle delibere di assemblee di soci non può estendersi alla valutazione del mérito e al controllo sovrano della volontà dei soci, ma deve limitarsi a um riscontro di legittimità. Ancorchè questo riscontro, oltre ad avere riguardo alle norme di legge o statutarie, debba poi comprendere, in presenza di decisione assembleare deviata dal suo modo de essere, anche l'eccesso o l'abuso di potere."

269 TERRUSI, Francesco. L'Invalidità..., pág. 142: “...il giudice non controlla l'opportunità o la convenienza della soluzione adottata dalla delibera impugnata, ma deve stabilire solo che essa sia o meno il risultato del legittimo esercizio del potere discrezionale dell'organo deliberante (Cass. 19.4.2003, n.6361, FI 2004, I, 1219, in motivazione. Conf. Cass. 20.4.2001, n. 5889, RFI 2002, voce Comunione e condomínio, n. 133)."

${ }^{270}$ TERRUSI, Francesco. L'Invalidità..., pág. 150: "L'individuazione del modo migliore per perseguire l'interesse sociale è rimesso, infatti, all'insindacabile apprezzamento degli organi sociali a ciò deputati. (Cass. 11.6.2003, n. 9353, FI 2004, I, 1219).”.
} 
O parágrafo $6^{\circ}$ do artigo 159 da Lei das S.A. transpôs para o direito Brasileiro norma baseada nesses mesmos princípios, estabelecendo, ao tratar da ação de responsabilidade contra administrador: "\$ $6^{\circ} \mathrm{O}$ juiz poderá reconhecer a exclusão da responsabilidade do administrador, se convencido de que este agiu de boafé e visando ao interesse da companhia."

Assim, além dos poderes outorgados pelo Estatuto Social e pela lei aos administradores, este dispositivo estabelece o que Osmar Brina Corrêa-Lima ${ }^{271}$ denomina "poderes implícitos" dos administradores. Traçando um paralelo com a doutrina que trata dos poderes discricionários no direito administrativo, esse artigo reconhece a necessidade de existência de uma margem de discricionariedade, por parte dos administradores, para que possam tomar a decisão que entendam ser a melhor para a companhia naquele momento.

Osmar Brina Corrêa-Lima, reproduz definição de Hely Lopes Meirelles, adaptando-a para o direito societário: "Poder discricionário é o que o direito concede aos administradores de um modo explícito ou implícito, para a prática de atos em nome da companhia, com liberdade na escolha de sua conveniência, oportunidade e conteúdo." 272

E o poder discricionário reconhecido ao administrador das sociedades por ações, para agir no interesse da companhia, encontra limitação justamente na arbitrariedade, exatamente como ocorre no direito administrativo, conforme discorre Hely Lopes Meirelles ${ }^{273}$ : "Convém esclarecer que poder discricionário não se confunde com poder arbitrário. Discricionariedade e arbítrio são atitudes inteiramente diversas. Discricionariedade é liberdade de ação administrativa, dentro dos limites permitidos em lei; arbítrio é ação contrária ou excedente da lei. Ato discricionário, quando autorizado pelo Direito, é legal e válido: ato arbitrário é sempre ilegítimo e inválido."

${ }^{271}$ Sociedade Anônima...., pág. 261.

${ }^{272}$ Sociedade Anônima...., pág. 261.

${ }^{273}$ Direito Administrativo Brasileiro, pág. 103. 
Desta forma, ainda que uma decisão tomada pela administração de uma companhia gere prejuízos para esta ou se revele não ter sido a melhor orientação empresarial para os negócios da companhia, a decisão deverá ser mantida e os administradores isentos de responsabilidade se comprovado que agiram de boa-fé e tomaram as cautelas necessárias e usuais para buscar os interesses da sociedade e preservá-la dos resultados negativos.

A proteção dos administradores de boa-fé nas situações em que uma orientação empresarial gere prejuízos para a companhia ou se revele não ter sido a melhor para os seus negócios é essencial para proteção patrimonial e pessoal dos empresários e dos executivos no exercício dos poderes que os seus cargos the conferem, e para atuação discricionária, dentro dos limites legais e estatutários, procurando sempre aproveitar as oportunidades que surjam, no melhor interesse da companhia. Além disso, os juízes não possuem a expertise necessária para determinar os rumos de uma sociedade e avaliar o mercado em que ela atua, ao contrário dos administradores que foram nomeados pelos acionistas, justamente por possuírem o preparo necessário.

Outro aspecto importante que deve ser considerado, na avaliação e pretensão de revisão judicial de decisões empresariais e que oferece limites a essa pretensão, é o fato de que, ao se julgar os resultados de uma decisão de negócio tomada, já se conhecem os resultados gerados por ela e vários outros fatores que influenciam os resultados dessa decisão ocorreram o que torna mais fácil determinar qual teria sido a melhor decisão para a companhia em um determinado momento. O administrador não possui esses dados e deve trabalhar com informações e projeções. O que se espera dele é que tome as cautelas necessárias para informar-se quanto aos riscos envolvidos, agir de boa-fé e buscar sempre alcançar os melhores resultados para a companhia.

Alexandre Couto Silva ${ }^{274}$ distingue ainda, com base na experiência norte-americana, cinco fatores considerados pelos tribunais para proteção dos administradores no exame e questionamentos envolvendo a administração de sociedades:

${ }^{274}$ A Regra do Julgamento...., pág. 256. 
"a) - no primeiro fator, os tribunais reconhecem que, mesmo desinteressados, bemintencionados e informados, os administradores poderão tomar decisões, que se apresentarão, em longo prazo, como decisões em cuidado ou planejamento, fazendo com que a companhia perca grandes somas de dinheiro. Por essa razão, a regra do julgamento do negócio encoraja pessoas competentes a se tornarem administradores que sem a regra declinariam por receio de serem pessoalmente responsabilizados.

b) - no segundo fator, a regra do julgamento do negócio reconhece que os atos dos administradores, por si sós, representam um risco e incerteza, por isso encoraja os administradores a engajar em atividades que têm potencial para ótimos retornos, mas com alguns riscos. Os administradores têm que ter discricionariedade para entrar em novos mercados, desenvolver novos produtos, inovar e assumir outros riscos. Comumente citado, os fundadores da McDonald's Corporation que investiram US\$ 3 milhões na patente de uma nova técnica de fabricar hambúrguer, nunca teriam tomado essa decisão lucrativa.

c) - no terceiro fator, a regra do julgamento do negócio evita que os tribunais se envolvam em complicados casos de tomada de decisão, tarefa que os tribunais não estão devidamente equipados para executa-la. Os administradores são, na maioria dos casos, mais qualificados para tomada de decisão que os juízes. Entretanto, para um juiz é relativamente fácil verificar se o administrador tomou a decisão de boa-fé, devidamente informado e com cautela, no interesse da companhia.

d) - no quarto, a regra do julgamento do negócio garante aos diretores mais do que os acionistas. Se aos acionistas é concedido o direito de demandar revisão de decisões dos administradores, o resultado pode ser a transferência de autoridade do conselho de administradores para qualquer acionista que deseje reclamar. Em resumo, a regra do julgamento do negócio protege a sociedade e seus acionistas de outros acionistas.

e) - no quinto, os tribunais entendem que acionistas descontentes podem sempre destituir administradores." 
No Brasil, assim como na Itália, a organização interna das sociedades por ações é diferente da estrutura das empresas norte-americanas. A Assembléia Geral de acionistas é o órgão máximo para decisões da empresa e manifestação dos acionistas, ao contrário do que ocorre nos Estados Unidos, onde os administradores detém maior poder para determinação dos negócios da sociedade. Os administradores são os destinatários e executores das decisões assembleares ${ }^{275}$. Por esse motivo, no Brasil, o controle do mérito das decisões tomadas pelos administradores cabe à Assembléia Geral.

Essa característica da estrutura das companhias brasileiras de forma alguma exclui a responsabilidade dos administradores na prática de atos de administração, que tenham sido determinados em Assembléia. Os administradores devem observar seus deveres para com a companhia e seus acionistas e reportar aos demais acionistas ou deixar consignada sua discordância com relação à legitimidade de alguma diretriz ou orientação que lhe foi passada, ainda que aprovada em Assembléia Geral, sob pena de serem responsabilizados pelos prejuízos causados (art. 158).

Assim, de acordo com os princípios que estruturam a legislação Brasileira, podemos concluir que a Regra de Julgamento do Negócio também pode ser aplicada, com as devidas adaptações ao sistema da Lei 6.404, na análise da legalidade de atos societários. O Judiciário deve se ater a verificar se as deliberações e atos impugnados contém vícios que afetem sua legalidade e se a conduta dos administradores e controladores está de acordo com o padrão determinado pelo art. 153 da Lei das S.A. Desta forma, ainda que o resultado da companhia ou de determinadas operações, se revelem negativas para a companhia, os acionistas, especialmente os controladores e os administradores, estão resguardados de responsabilidade pessoal, se comprovado que agiram de boa-fé. Alterando-se esses princípios de responsabilidade, que estão interligados aos princípios da livre iniciativa, os riscos inerentes à realização de um empreendimento seriam transferidos aos administradores, o que não se pode admitir.

${ }^{275}$ ASCARELLI, Túlio. Vícios ..., em Problemas..., pág. 533. 


\section{IV.6 - INOBSERVÂNCIA DOS REQUISITOS FORMAIS DE CONVOCAÇÃO, REALIZAÇÃO E PUBLICIDADE DAS ASSEMBLÉIAS GERAIS}

O princípio da publicidade dos atos societários, exige que, para validade das deliberações societárias, os acionistas: (a) deverão ser informados do dia, horário e local da realização da Assembléia; (b) ser informados com clareza de todos os assuntos que serão nela deliberados, com antecedência para que possam se preparar para as deliberações; (c) terão direito de acesso à Assembléia, ainda que tenham seu direito de voto limitado; (d) terão acesso a cópia da ata das Assembléias, lavradas em livro próprio e que serão também publicadas. O resultado das deliberações constará de ata lavrada em livro da sociedade, arquivada no órgão competente do Registro do Comércio e publicada em jornal da impressa oficial e outro jornal que circule na sede da companhia (arts. 121 e seguintes). Anualmente, as companhias deverão realizar um Assembléia Geral Ordinária para deliberar sobre as contas apresentadas pelos administradores, relativas ao exercício encerrado e votar as demonstrações financeiras, deliberar sobre a destinação do lucro líquido do exercício e a distribuição de dividendos e eleger os administradores e membros do Conselho Fiscal, se for o caso (art. 132).

Todas essas providências visam não apenas resguardar os

direitos dos acionistas, para que tomem conhecimento dos assuntos envolvendo a empresa, os rumos de seus negócios e alterações no Estatuto Social, como também terceiros relacionados à companhia que também poderão acompanhar os resultados da companhia e as principais deliberações tomadas, que definem os rumos e os resultados de seus negócios. Cabe ao órgão competente do Registro do Comércio verificar o cumprimento dessas providências e, em se tratando de deliberações que alteram o Estatuto Social, o art. 97 e o $\S 1^{\circ}$ do art. 135 conferem a esse órgão poder para negar o arquivamento do ato societário, se constatar a existência de cláusulas contrárias à lei, à ordem pública e aos bons costumes. Nas demais hipóteses de deliberações 
assembleares, o Registro do Comércio não possui poderes tão amplos e somente poderá se opor se o vício que afeta a validade da deliberação for flagrante.

Em atendimento a esse princípio e para estabelecer os procedimentos que deverão ser adotados pelos administradores e acionistas, para convocação, instalação, condução dos trabalhos, registro e publicação das atas, a Lei 6.404 estabelece os prazos para publicação de avisos, convocações e informações sobre documentos da companhia (arts. 123 a 126), quoruns de instalação, em primeira e segunda convocação (arts. 125 e 135) e de deliberação, os quais, de acordo com a matéria a ser deliberada, dependerá de aprovação por maioria simples ou qualificada, ou da aprovação de uma classe determinada de acionistas (arts. 129 e 136), a forma de condução dos trabalhos e lavratura da ata (arts. 127 a 130) e os procedimentos e prazos de registro e publicação dos atos societários (art. 130, $\S 5^{\circ}$ do art. 134 e $\S 1^{\circ}$ do art. $135)$.

O legislador procurou assim estabelecer procedimentos que permitam aos acionistas e terceiros tomar conhecimento dos resultados das deliberações, das manifestações dos acionistas, inclusive dissidentes, e verificar o atendimento aos prazos e procedimentos que conferem legitimidade e validade às deliberações.

Desta forma, os vícios que atingem as deliberações assembleares, podem ser de duas naturezas: os que afetam a validade da deliberação e aqueles que afetam a validade do voto ${ }^{276}$.

O art. 286 da Lei das S.A. prevê o prazo de 2 anos, contado da deliberação, para ajuizamento de ação para “...anular as deliberações tomadas em assembléia-geral ou especial, irregularmente convocada ou instalada, violadoras da lei ou do estatuto, ou eivadas de erro, dolo, fraude ou simulação."

Esse prazo reduzido, em relação ao prazo para anulação de atos do direito civil, é necessário e característico da rapidez com que se os negócios

${ }^{276}$ ASCARELLI, Tulio. Vícios..., em Problemas..., pág. 533. 
empresariais se concluem, como aponta Erasmo Valladão Azevedo e Novaes França ${ }^{277}$ : "Não há qualquer dúvida de que a adoção de um regime de anulabilidades, diverso do regime comum, e prescritível em prazo mais abreviado, visa atender a uma necessidade prática de estabilidade das deliberações assembleares, a fim de não ficarem estas expostas, durante longo tempo, aos azares decorrentes da eventual propositura de uma ação anulatória. Em prazo mais curto ficam os interessados, ou advertidos da possibilidade de ser invalidade a deliberação - se proposta a demanda no prazo legal -, ou, na hipótese contrária -, seguros da plena eficácia do ato. O interesse na estabilidade das deliberações, de resto, não se deve apenas à circunstância de tais atos poderem atingir um círculo muito vasto de pessoas e, sobretudo nas companhias abertas, a todo tempo mutável, mas, especialmente, aos danos que poderiam advir à própria gestão da empresa social, se sujeitos à impugnação em prazo muito dilatado."

Analisando os motivos pelos quais há necessidade de se estabelecer regras especiais para o sistema de validade das deliberações assembleares em relação ao sistema aplicável aos demais atos jurídicos, Francesco Terrusi ${ }^{278}$ conclui que a exigência de estabilidade, certeza e rapidez dos atos societários decorre do contexto peculiar no qual tais atos são destinados a se inserir, que pressupõe uma série indefinida de relações com terceiros. Tais objetivos são alcançados através da limitação das causas de nulidade e possibilidade de anulação dos demais casos de irregularidade das deliberações, a fixação de prazos inferiores de decadência e prescrição, além de limitação dos sujeitos legitimados a ajuizar ação para requerer a anulação de atos societários e a preservação dos direitos adquiridos de boa-fé por terceiros com base nos atos realizados em decorrência das deliberações tomadas, ainda que venham a ser anuladas ou declaradas nulas.

277 Invalidade...., pág. 69.

${ }^{278}$ L'Invalidità..., pág. 66: "Il senso può essere individuato nella seguente espressione di sintesi: $i$ ) ai fini della ratio del sistema delineato dagli artt. 2377-2379 c.c. vengono in rilievo esigenze di stabilità, di certezza e di rapidità; $i$ ) queste esigenze si impongono in relazione al peculiare contesto organizzativo nel quale le deliberazioni sono destinate a inserirsi, um contesto che suppone l'instaurarsi di uma serie indefinita di rapporti com soggetti terzi; iii) l'obiettivo è raggiunto attraverso $a$ ) la limitazione delle cause di nullità e la degradazione di ogni diversa, ipotizzabile, patologia della deliberazione a causa di annullamento; $b$ ) la consequenziale riconduzione a quest'ultima fattispecie (art. 2377 c.c.) di ogni difetto concernente l'iter formativo della deliberazione (il vizio cd. procedimentale); $c$ ) la previsione di limitazioni circa la proponibilità dell'azione di annullamento, sotto i profili temporale (com fissazione di um termine di decadenza di soli tre mesi) e di legittimazione (con selezione dei soggetti abilitati all'esercizio dell'azione); $d$ ) la salvezza dei diritti acquistati in buona fede dai terzi in base ad atti compiuti in esecuzione della deliberazione annullabile (cfr. Art. 2377, $3^{\circ}$ co., c.c. versione originaria, ed ora art. $2377,7^{\circ}$ co., c.c.), diritti che, invece, in caso di generalizzata estensione della fattispecie di nullità, verrebbero irrimediabilmente travolti. (Profilo, quest'ultimo, da sempre estremamente controverso...)." 
O artigo 2379 do Código Civil Italiano, de forma semelhante ao sistema brasileiro, prevê que apenas nos casos de ilicitude ou impossibilidade do objeto da deliberação esta será nula e, nas demais hipóteses (falta de convocação da assembléia, falta da ata da assembléia, ilegitimidade do voto determinante da deliberação), a deliberação poderá ser anulada e o Código prevê procedimentos para regularizar essas irregularidades. Nos casos de uma deliberação anulável, os acionistas e administradores da companhia poderão, mesmo após ajuizamento de ação para anular a deliberação, retificar e revalidar o ato.

Enquanto a deliberação não for anulada por sentença transitada em julgado, ela produzirá efeitos, perante a companhia, os acionistas e terceiros a menos que tenha sido deferida medida judicial suspendendo seus efeitos até julgamento definitivo da questão. Tullio Ascarelli ${ }^{279}$ ressalta que os princípios de publicidade dos atos societários devem ser observados, quanto à eficácia retroativa da anulação e da declaração de nulidade, em razão dos direitos que terceiros possam ter adquirido em razão da deliberação declarada nula ou anulada. Conclui o autor que, "a nulidade ou a anulação de uma modificação estatutária (devidamente arquivada e publicada) não pode ter eficácia retroativa quanto aos terceiros; estes, com efeito, agindo com a sociedade, tinham o direito de confiar na legalidade das suas deliberações, visto que estas foram, justamente quanto à legalidade, verificadas pelo órgão competente."

A doutrina e jurisprudência italianas também prevêm hipóteses muito restritas em que uma deliberação é considerada inexistente, não produzindo quaisquer efeitos, perante a companhia, seus acionistas ou terceiros. A Corte de Cassação Italiana consolidou entendimento de que nos casos em que se declara a inexistência da deliberação, o ato analisado não possui os requisitos procedimentais mínimos indispensáveis para a formação de uma deliberação imputável à sociedade, por faltar estrutura funcional ou estrutural adequadas ao modelo normativo ${ }^{280}$. Por esses

\footnotetext{
${ }^{279}$ Vícios..., em Problemas..., págs. 558 e 559.

${ }^{280}$ Conforme decisão transcrita por TERRUSI, Francesco. L'Invalidità..., pág. 72 (Cass. 11.6.2003, n. 9364, FI 2004, I. 176): "Secondo la giurisprudenzia di questa Corte, l'ipotesi di inesistenza della delibera assembleare di una società di capitali recorre quando manchi alcuno dei requisiti procedimentali indispensabili per la formazione di uma delibera imputabile alla società, con il risultato di determinare una fattispecie apparente, non sussumibile nella categoria giuridica delle deliberazione assembleari per
} 
motivos, ele não pode produzir qualquer efeito, é um "nada jurídico", nas palavras de Tullio Ascarelli ${ }^{281}$.

Nas palavras deste autor, "É difícil, por certo, distinguir os requisitos, cuja falta dá lugar à inexistência da deliberação e aqueles, cujo inadimplemento, ao contrário, dá lugar a um dos vícios enunciados no item 'f' [violação das regras que regulam a assembléia e o procedimento de suas deliberações]. Não parece, no entanto, negável, ser necessária uma ‘deliberação', para que se possa, depois, examinar se válida ou viciada: na falta de uma deliberação, não se pode falar em deliberação viciada e em prescrição da correspondente ação de anulação, mas somente em um nada jurídico, que 'nulum producit effectum'."

Os autores italianos, enfrentando esse problema, procuraram especificar as hipóteses em que as irregularidades de realização da assembléia (assim incluídos os procedimentos que determinam sua convocação, instalação e realização dos trabalhos), não teriam uma consequiência tão drástica quanto a declaração de inexistência da Assembléia e das deliberações nela tomadas. Para isso, estabeleceram os requisitos que permitem depreender que, no mínimo, foi possível a todos os acionistas tomar conhecimento de que a reunião seria realizada, sua pauta e o local de sua realização.

Assim, ainda que não tenha havido convocação da assembléia, se a totalidade dos acionistas compareceu ao local combinado e pôde deliberar, não se pode considerar que a assembléia não ocorreu e que a decisão inexiste ${ }^{282}$. São as hipóteses em que a convocação é enviada por apenas um administrador, quando deveria ser enviada por dois ou mais administradores ou ainda quando não tenha sido observado o prazo mínimo previsto para envio da convocação; nesses casos, as deliberações tomadas nas reuniões realizadas em decorrência dessas convocações irregulares são anuláveis.

inadeguatezza strutturale o funzionale rispetto al modello normativo (Cass. 835-1995, nonché Cass. 11186-2001, in motivaz., e le più risalenti Cass. 11601-1990, 1768-1986 e 6340-1981).”

${ }^{281}$ Problemas..., pág. 549.

${ }^{282} \mathrm{O}$ parágrafo $4^{\circ}$ do artigo 124 determina a regularidade da assembléia geral a que comparecerem todos os acionistas, ainda que não tenham sido observadas as formalidades da convocação previstas neste artigo. 
Por outro lado, as decisões tomadas em uma reunião a que compareceram alguns acionistas de uma companhia, sem que os demais ausentes tenham sido convocados para participar, não pode produzir efeitos, perante os acionistas ou a própria companhia, ainda que o quorum representado pelos acionistas presentes seja suficiente para aprovação das deliberações tomadas.

Da mesma forma, se a reunião de sócios ocorre em local diverso do previsto no aviso de convocação, sem que todos os acionistas tenham tido conhecimento, de forma inequívoca, da alteração do local da reunião ou ainda, não existindo convocação e não tendo os sócios se reunido para discutir as matérias e deliberar, também não se pode entender que houve Assembléia e, portanto, as decisões tomadas não podem vincular a companhia, seus acionistas e terceiros ${ }^{283}$.

As normas de convocação e realização da assembléia geral, previstas em lei e no Estatuto, são determinadas justamente para garantia dos acionistas de que terão conhecimento prévio das matérias a serem discutidas e do local da reunião, permitindo que compareçam ou possam enviar representante com poderes para participar da Assembléia e nela votar e, ainda que sejam derrotados na votação, possam participar dos debates envolvendo a matéria em discussão.

283 TERRUSI, Francesco. L'Invalidità..., pág. 72 (Cass. 11.6.2003, n. 9364, FI 2004, I. 176): "Nell'applicazione, poi, di tale principio, questa corte há affermato (l'indagine è ovviamente, limitata alle anomalie procedimentali riguardanti la convocazione, le sole qui rilevanti) che la situazione sopra descritta si verifica - qualora non si tratti di assemblea totalitária - nei casi di omessa convocazione dei soci (Cass. 11186-2001, 1768-1986 e 6340-1981, citt.), o di omessa convocazione e mancata adunanza dei soci (Cass. 835-1995, cit.) o di svolgimento dell'assemblea in luogo diverso da quello indicato nell'avviso di convocazione, di modo che non vi sia certezza che tutti i soci siano stati messi in grado di parteciparvi (Cass. 403-1993)." 
Giancarlo Laurini ${ }^{284}$ ressalta a importância do papel e as responsabilidades do presidente eleito, na condução dos trabalhos da Assembléia para que esta transcorra regularmente e não ocorram problemas procedimentais que prejudiquem a participação de qualquer acionista e possam acarretar a anulação das deliberações tomadas. Segundo este autor, caso o Estatuto ou outro regulamento interno da companhia não prevejam expressamente o sistema de votação, caberá ao presidente da Assembléia determinar o sistema de apuração de votos que entenda mais oportuno (através de aclamação ou contagem individual dos votos, voto secreto ou aberto, etc.), estando essa prerrogativa dentro do âmbito dos poderes técnicos diretivos da Assembléia que lhe são atribuídos quando de sua escolha para ocupar a presidência da mesa. No entanto, caso o Estatuto ou outro regulamento interno contemplem forma específica para votação, o Presidente não poderá impedir que o sistema de votação prédeterminado seja aplicado, ainda que ilegítimo ${ }^{285}$, mas tem o dever de informar a todos os presentes, acerca da ilegalidade do sistema adotado pelo Estatuto ou regulamento e a possibilidade de anulação das deliberações tomadas.

Enfatizando ainda a responsabilidade do Presidente eleito na condução dos trabalhos da Assembléia, Giancarlo Laurini ${ }^{286}$ sustenta que, em caso de

\footnotetext{
${ }^{284}$ Poteri i Responsabilità..., pág. 61: "Pertanto nel rispetto dello statuto e della legge, il presidente può scegliere, nel regolare la votazione, la forma espressiva che ritenga più opportuna, dall'azata di mano com successiva identificazione o contraprova, alla chiamata per singolo sócio, dall'acclamazione alla compilazione di schede prestampate, e cosi via. È però illegittimo che il presidente individui criteri che non garantiscano una libera, chiara e regolare espressione del voto, che non consentano um preciso accertamento di uma volontà collegiale maggioritaria o che comunque violino principi generali dell'ordinamento. Di contro, laddvove lo statuto contempli espressamente um sistema di voto illegitimo, il presidente non può vietare che la votazione avvenga con quel sistema, ma deve rendere edotti i soci del vizio e del fatto che conseguentemente la deliberazione assunta potrebbe essere invalidata. Il vizio nato da un sistema di voto illecito, infatti, va sicuramente ricondotto alla categoria dell'annullabilità, trattandosi di vizio che riguarda il procedimento di formazione della delibera e pertanto non va fatta distinzione tra l'ipotesi in cui la votazione è assunta sulla base di uma clausola statutaria, da quella in cui sia determinata dall'assemblea o dal presidente. Anche nel secondo caso, infatti, la tipizzazione delle cause di nullità impedisce di utilizzare la relativa azione fuori dall'ambito normativamente previsto. Diversa è invece l'ipotesi in cui insieme alla delibera viziata venga impugnata la clausola statutaria illecita".

${ }^{285}$ Caso, por exemplo, contenha alguma disposição que impeça os acionistas de se manifestar durante as discussões relativas às matérias debatidas ou que impeça um determinado acionista ou categoria de acionistas de participar da própria Assembléia.

${ }^{286}$ Poteri e Responsabilità..., pág. 132: "L'area delle possibilita risarcitorie a favore del socio viene ulteriormente ristretta laddove si affermi l'insussistenza in concreto del danno, come nel caso in cui il socio al quale illegittimamente non sai stato consentito di partecipare alla assemblea abbia ottenuto l'annullamento della delibera ovvero abbia fatto spirare il termine per l'impugnativa, sanando il vizio della deliberazione. In tal caso si ravvisa, al limite, uma responsabilità presidenziale nei confronti della società, ritenendosi che la delibera viene annullata a causa di un comportamento doloso del presidente, e gli eventuali danni che la società dovesse subire in conseguenza di questo evento non possono di certo gravare sul patrimonio sociale, ma devono essere risarciti dall'autore del danno provocato contravvenendo ai doveri del suo ufficio."
} 
anulação de uma deliberação à qual um acionista foi impedido de participar, por decisão do Presidente, ou em que este agiu, durante a Assembléia, com dolo, os danos causados ao acionista e à companhia deverão ser suportados pelo Presidente daquela Assembléia, que os deverá ressarcir à companhia, para que esta não tenha seu patrimônio prejudicado pelo desvio de conduta do Presidente que não agiu em conformidade com a Lei, os Estatutos ou Acordos de Acionistas existentes.

A ata da Assembléia Geral deverá reproduzir fielmente os acontecimentos ocorridos durante seus trabalhos, desde sua instalação, local e horário de realização, os assuntos integrantes da pauta do dia, constantes da convocação, os integrantes da mesa diretora, eventuais propostas, declarações de votos dissidentes ou protestos, sendo, ao final, assinada pelos integrantes da mesa e, no mínimo, pelos acionistas que representem o quorum necessário para aprovação das matérias deliberadas, nos termos do artigo 130 da Lei das S.A. A ata, elaborada e assinada na forma da lei, faz prova das deliberações tomadas e fatos ocorridos durante a Assembléia. De fato, considerando que a lei estabelece um procedimento detalhado de convocação, instalação e realização das Assembléias Gerais e exige a transcrição dos acontecimentos ocorridos, lavratura da ata em livro próprio, arquivamento da ata no Registro competente e posterior publicação, a fim de proteger os interesses dos acionistas e terceiros envolvidos e dar publicidade das deliberações tomadas, se não existe ata da Assembléia que se alega ter sido realizada, não há como comprovar a regular instalação da Assembléia e das deliberações tomadas e a aprovação pelos sócios representantes do quorum exigido, não sendo possível comprovar a legitimidade das deliberações tomadas ${ }^{287}$.

Giancarlo Laurini ressalta a importância do conteúdo da ata da Assembléia, para proteção dos interesses dos acionistas, servindo como meio de prova

287 Como acima exposto, a ausência de ata da Assembléia é uma das três causas de nulidade de deliberações societárias, estabelecidas pela nova redação do artigo 2379 do Código Civil Italiano. LAURINI, Giancarlo. Poteri e Responsabilità..., pág. 95, analisando o primeiro parágrafo do artigo 2375 do Código Civil Italiano, observa: "Le deliberazioni dell'assemblea devono constare da verbale sottoscritto dal presidente e da segretario o dal notaio. Nel verbale devono essere riassunte, su richiesta dei soci, le loro declarazioni." E conclui que a ata tem função constitutiva da deliberação nela constante: "Per quanto attiene alla natura meramente 'certificativa' del verbale, cui il sopra richiamato texto del 2375 aveva fatto legittimamente pensare, essa è stata totalmente vanificata dalla riforma che, aggiungendo la mancanza del verbale alle altre tre causa di nullità della delibera tassativamente indicate nel texto novellato dell'art. 2379 c.c., ha fatto assurgere il verbale stesso a elemento costitutivo della delibera, dal quale non è possibile prescindere nel suo processo formativo." 
dos fatos ocorridos durante a Assembléia e possibilitando o controle sobre as deliberações tomadas pela maioria ${ }^{288}$.

O papel do Presidente e do Secretário da Assembléia assume especial importância ao se analisar as conseqüências que a incorreta instalação da Assembléia, condução dos trabalhos ou da redação da ata acarretam para legitimidade das deliberações tomadas. Cabe ao Presidente verificar a legitimidade dos acionistas presentes e quais são, dentre os sócios presentes, os impedidos de votar (quando, por exemplo, tratar-se de um dos casos expressamente previstos nos artigos 115$)^{289}$, conduzir os trabalhos dentro das matérias constantes da ordem do dia $^{290}$, assegurar que os acionistas presentes possam se manifestar sobre os assuntos debatidos, interromper os trabalhos quando necessário, confirmar se o quorum de instalação foi alcançado, seja em primeira ou segunda convocação e se houve aprovação ou não da deliberação, em função dos votos atribuídos aos acionistas. Os parágrafos $8^{\circ}$ e $9^{\circ}$ do artigo 118 , com a redação da Lei $10.303 / 01^{291}$, atribuem, ao Presidente da Assembléia, a função de

${ }^{288}$ Poteri e Responsabilità..., pág. 96: "Quanto al contenuto, va considerato che la redazione dei verbali delle assemblee è imposta dalla legge non solo al fine di creare uma documentazione di un'attività o di determinate deliberazioni, ma anche come mezzo di constatazione di eventi nell'interesse del singolo azionista. La funzione del verbale, cioè, non è solo quella di un pro-memoria in ordine all'attività assembleare ad uso della società e dei terzi, ma anche quella di rendere possibile un controllo da parte dei soci sull'attività dell'assemblea e sulla legalità del suo procedere, come necessário 'contrapeso' al principio della maggioranza."

${ }^{289}$ É importante ressaltar que não cabe ao Presidente da Assembléia ou aos membros da mesa diretora, impedir um acionista de votar em caso de suspeita de conflito de interesses, quando não se tratar das deliberações relativas ao laudo de avaliação de bens com que o acionista concorrer para a formação do capital social ou à aprovação de suas contas como administrador, que são os casos expressamente previstos na primeira parte do art. 115, conforme entendimento de FRANÇA, Erasmo Valladão Azevedo e Novaes. Invalidade..., pág. 93, nota 60: "Mantemos, todavia, a opinião, expressada anteriormente (...), de que a mesa diretora do conclave não tem o poder de impedir o voto que entenda conflitante com o interesse da companhia (última hipótese prevista no $\S 1^{\circ}$ do art. 115), por não consistir, propriamente, naquela hipótese, em um caso de proibição de voto (que é, porém, o caso das outras três hipótesesprevistas no mencionado $\S 1^{\circ}$ do art. 134, e $2^{\circ}$ do art. 228)."

${ }^{290}$ É importante que a convocação especifique com clareza todos os assuntos que serão debatidos na Assembléia. A menção a "assuntos de interesse da companhia" é insuficiente tendo em vista que na Assembléia Geral somente poderão ser discutidos assuntos que interessem à companhia. A deliberação de assuntos que não estavam previstos na ordem do dia afeta a validade das deliberações tomadas que poderão ser impugnadas se os acionistas não tiveram conhecimento de que essas matérias seriam objeto de discussão naquela Assembléia e não forem consequiência direta das outras deliberações constantes da ordem do dia (como por exemplo, no caso de deliberação, em Assembléia Geral Ordinária, sobre ajuizamento de ação de responsabilidade contra administrador da companhia, $\S 1^{\circ}$ do art. 159).

291 “ $\$ \mathbf{8}^{\mathbf{0}}$ O presidente da assembléia ou do órgão colegiado de deliberação da companhia não computará o voto proferido com infração de acordo de acionistas devidamente arquivado. $\$ \mathbf{9}^{\mathbf{0}} \mathrm{O}$ não comparecimento à assembléia ou às reuniões dos órgãos de administração da companhia, bem como as abstenções de voto de qualquer parte de acordo de acionistas ou de membros do conselho de administração eleitos nos termos de acordo de acionistas, assegura à parte prejudicada o direito de votar com as ações pertencentes ao acionista ausente ou omisso e, no caso de membro do conselho de administração, pelo conselheiro eleito com os votos da parte prejudicada." 
assegurar o cumprimento dos acordos de voto constantes de Acordo de Acionistas arquivados na sede da companhia, não computando o voto proferido com infração ao estabelecido no Acordo de Acionistas ou ainda permitindo que outro acionista vote no lugar do acionista participante do Acordo que faltou à Assembléia ou se absteve de $\operatorname{votar}^{292}$.

Após encerramento dos trabalhos da Assembléia e lavratura da ata, os administradores deverão providenciar seu arquivamento na Junta Comercial competente, e publicação nos jornais onde costumeiramente se publicam os atos da sociedade e, por fim, arquivar uma via das publicações na Junta Comercial.

A falta de arquivamento da ata na Junta Comercial ou de publicação nos jornais, na forma e prazos previstos em lei, interferem na eficácia das deliberações tomada na Assembléia, aplicando-se o disposto nos artigos 135, § $1^{\circ}$ e 289 da Lei 6.404, além de atribuir responsabilidade pessoal dos administradores pelo descumprimento de seus deveres de diligência.

Outro ponto de fundamental importância para a eficácia das deliberações tomadas é a publicação da ata nos jornais competentes, tendo em vista, inclusive, que a data da publicação da ata que aprova o balanço do exercício estabelece o início do prazo de prescrição para ajuizamento da ação prevista no item "b", II do art. 287. Em se tratando de deliberações que alteram o Estatuto, a falta de arquivamento e publicação da ata da Assembléia não poderá ser oposta pela companhia ou seus acionistas, a terceiros de boa, na forma do $\S 1^{\circ}$ do art. 135. A única forma de sanar essa irregularidade é através do arquivamento e publicação da ata em questão, mas os efeitos decorrentes do arquivamento e publicação dos atos, não terão efeito retroativo ${ }^{293}$.

\footnotetext{
${ }^{292}$ Caso o Presidente da Assembléia não desconsidere o voto declarado em desacordo com o Acordo de Acionistas arquivado na sede da companhia, os acionistas prejudicados poderão requerer que o Judiciário declare o voto em conformidade com o ajustado entre as partes do Acordo, suprindo a declaração de vontade manifestada contrariamente ao acordado, tendo em vista que as regras previstas nos Acordos de Acionistas comportam execução específica, nos termos do parágrafo $3^{\circ}$ do artigo 118 e dos artigos 466-A, 466-B e 585, inc. VII, do Código de Processo Civil.

${ }^{293}$ Conforme ASCARELLI, Tullio. Vícios..., em Problemas..., pág. 517.
} 


\section{IV.7 - ARBITRAGEM}

Um dos limites impostos por lei, para atuação do Judiciário no âmbito das companhias, encontra-se na possibilidade de os sócios estabelecerem cláusula arbitral no Estatuto Social, ficando submetidas, em razão da existência dessa disposição, a solução das divergências que vierem a ocorrer, entre acionistas e a companhia ou entre acionistas controladores e minoritários à solução por arbitragem, conforme parágrafo $3^{\circ}$ do artigo 109, incluído pela Lei $n^{\circ} 10.303 / 01$ : "§ $3^{\circ}$ O estatuto da sociedade pode estabelecer que as divergências entre os acionistas e a companhia, ou entre os acionistas controladores e os acionistas minoritários, poderão ser solucionadas mediante arbitragem, nos termos em que especificar."294

Esta tem se me mostrado uma boa alternativa empresarial para solução dos problemas oriundos das relações entre os sócios e a sociedade $^{295}$, considerando a possibilidade de escolha de profissionais técnicos conhecedores dos problemas apresentados, além da celeridade e sigilo que envolvem o processo arbitral e que protegem a companhia dos problemas advindos da divulgação da existência de discórdia entre os sócios, contestação de decisões tomadas ou atribuição de ocorrência de irregularidades na condução dos negócios sociais.

A Bovespa exige que os Estatutos Sociais das companhias participantes do Novo Mercado e do Nível 2 de Governança Corporativa, incluam a cláusula compromissória em seus Estatutos Sociais, elegendo a Câmara de Arbitragem do Mercado da Bovespa, para dirimir as dúvidas e controvérsias envolvendo essas companhias.

Essa exigência da Bovespa, reflete a insegurança que a atuação do Judiciário no Brasil traz àqueles que atuam no meio empresarial, em especial no

\footnotetext{
${ }^{294}$ O parágrafo $2^{\circ}$ do artigo 129 também prevê a possibilidade de os sócios socorrerem-se da arbitragem para desempate nas deliberações tomadas em assembléia geral.

295 Nos Estados Unidos, a arbitragem vem sendo utilizada com bastante frequiência para solucionar problemas societários, evitando-se os problemas enfrentados, especialmente com a demora e publicidade do Judiciário, conforme O'NEAL, F. Hodge e THOMPSON, Robert B. O'Neal's..., vol. 2, Capítulo 9, pág. 32: "Arbitration offers hope. In controversies between institutions, whenever traditional methods of settling disputes have broken down or have failed to meet changing commercial needs, the arbitral process has usually proved sufficiently flexible to do the job. Perhaps arbitration can be equally effective in settling intra-institutional disputes in closely held corporations."
} 
mercado acionário, tendo em vista que as práticas determinadas pela Bovespa a serem observadas pelas companhias que pretendem se adaptar a esses níveis diferenciados de Governança Corporativa, visam aumentar o grau de segurança dos investidores dessas companhias $^{296}$.

Em relação às demais companhias, sejam elas de capital aberto ou fechado, é conveniente que a cláusula arbitral contida no Estatuto estabeleça detalhadamente, dentre outros aspectos considerados importantes pelas partes, as regras principais aplicáveis ao procedimento arbitral, nos termos dos $\operatorname{artigos} 2^{\circ}, 4^{\circ}$ e $5^{\circ}$ da Lei 9.307/96, para se evitar que tais condições sejam detalhadas após instauração de litígio. Assim, recomenda-se que a cláusula arbitral preveja a câmara arbitral competente para instituir o processo de arbitragem, as regras a serem aplicadas para processamento da arbitragem, podendo as partes, inclusive, alterar, conforme sua conveniência, as regras estabelecidas pela câmara arbitral escolhida, os critérios, forma de escolha e impedimentos, além dos legais, dos árbitros escolhidos pelas partes, se a arbitragem será decidida por direito ou por eqüidade e ainda se os árbitros poderão utilizar-se dos princípios gerais de direito, usos e costumes para analisar as questões apresentadas e decidir o problema.

Instaurando-se uma divergência entre os sócios e esgotadas as possibilidades de se alcançar, internamente, uma solução para o problema, os sócios devem celebrar o compromisso arbitral, que é a convenção através da qual as partes submetem o litígio à arbitragem ${ }^{297}$. O compromisso arbitral pode ser judicial ou extrajudicial, conforme uma das partes resista à instauração do processo arbitral e deve conter os requisitos previstos nos artigos 10 e 11 da Lei de Arbitragem, respeitadas as regras já previstas pelos sócios na cláusula arbitral.

\footnotetext{
${ }^{296}$ A Bovespa criou níveis diferenciados de Governança Corporativa, para oferecer aos investidores das companhias que aderirem a essas categorias, "...melhorias nas práticas de governança corporativa que ampliam os direitos societários dos acionistas minoritários e aumentam a transparência das companhias, com divulgação de maior volume de informações e de melhor qualidade, facilitando o acompanhamento de sua performance. A premissa básica é que a adoção de boas práticas de governança corporativa pelas companhias confere maior credibilidade ao mercado acionário e, como conseqüência, aumenta a confiança e a disposição dos investidores em adquirirem as suas ações, pagarem um preço melhor por elas, reduzindo seu custo de captação. ", como consta no site da Bovespa, para apresentação das diferenças entre os diferentes níveis de Governança Corporativa, <http://www.bovespa.com.br/Principal.asp >. Acesso em 09.12.2008.

${ }^{297}$ Art. $9^{\circ}$ da Lei 9.307/96. CARMONA, Carlos Alberto. A Arbitragem no Processo Civil Brasileiro. São Paulo: Malheiros, 1993, pág. 82, conceitua compromisso arbitral da seguinte forma: "Em conclusão, o compromisso é o negócio jurídico processual através do qual os interessados em resolver um litígio, que verse sobre direitos disponíveis, deferem a sua solução a terceiros, com caráter vinculativo, afastando a jurisdição estatal, organizando o modo através do qual deverá se processar o juízo arbitral.”
} 


\section{V - CONSIDERAÇÕES FINAIS}

O presente trabalho propõe a análise dos princípios gerais que regem o funcionamento das sociedades por ações, e sua interpretação, sob a perspectiva dos limites de atuação do Poder Judiciário na administração das S.A. Restando demonstrado que a livre iniciativa privada é um princípio fundamental do sistema econômico e político brasileiro, não pode ser afastado, na análise dos atos de administração das S.A., o risco inerente à atuação empresarial, e que é de conhecimento de todos aqueles que procuram essa forma de investimento, com vistas no retorno do capital.

A atuação dos acionistas e controladores, na condução dos negócios da empresa, desde que de boa-fé e observados os deveres impostos pela lei, restringe as hipóteses em que o Judiciário pode intervir no funcionamento de uma companhia, apenas aos casos de comprovadas ilegalidades cometidas na tomada de decisões, não podendo interferir no mérito dessas decisões.

O interesse principal que a lei procura proteger, é o da companhia. Sua existência e a realização de suas atividades, tendo como limites a atenção aos interesses externos e atendimento à sua função social, coloca em segundo plano os interesses dos acionistas, ainda que estes não possam ser simplesmente ignorados ou omitidos, para benefício dos primeiros.

A necessidade de manutenção da existência produtiva da empresa é essencial para que se mantenha a produtividade e competitividade da economia, refletindo, assim, em benefícios para o Estado, os trabalhadores e a sociedade em geral, mas o exercício dessas atividades envolvem riscos do negócio, proporcionais ao retorno e ao tamanho do investimento. A produtividade e existência de uma companhia está diretamente relacionada às decisões de oportunidade e conveniência na realização de negócios, o que somente pode ser feito pelos acionistas e 
administradores eleitos, em observância à estrutura hierárquica administrativa das sociedades por ações.

A Lei das S.A. reconhece a necessidade de condução dos negócios pelo grupo ou acionista majoritário mas estabelece os princípios gerais que limitam o exercício do poder de controle de forma abusiva. A determinação de quais são esses interesses no caso concreto e a verificação se ocorreu ou não abuso na tomada de uma decisão exige uma investigação minuciosa do caso concreto e das características da sociedade envolvida.

Nesse sentido, passam a ser exigidos conhecimentos de outras áreas essenciais para compreensão dos problemas empresariais, tais como contabilidade, economia e administração de empresas. Ainda que a análise do caso, sob esses aspectos que extrapolam o Direito, deva ser feita por especialistas de cada área, a criação de varas especializadas em direito empresarial facilitará a compreensão dos casos pelos juízes encarregados de sua análise, que lidarão diariamente com os princípios de Direito Societário.

Essa familiaridade e especialização dos juízes com a área certamente será benéfica para o desenvolvimento de uma jurisprudência coerente, que ofereça segurança aos agentes do mercado e estimule aqueles que se julguem prejudicados por atos praticados as S.A, a procurar a reparação dessas situações.

A criação de uma jurisprudência coerente com os princípios de Direito Societário servirá também para estabelecer os limites e desestimular a má-fé e falta de lealdade de empresários oportunistas, o que também aumentará a confiança dos investidores no mercado e nas instituições que o regulam e fiscalizam.

Esse deve ser o papel do Judiciário ao tratar dos casos envolvendo Direito Societário: assegurar a liberdade dos empresários na condução de seus negócios, fortalecendo os princípios de ética e lealdade que são fundamentais para o desenvolvimento das empresas e do mercado de capitais, procurando, em cada caso equilibrar esse princípio com os demais princípios gerais contidos na Lei ${ }^{\circ}$ 6.404/76, para preservação dos demais interesses envolvidos. 
Por fim, é importante comentar que à época da finalização desse trabalho, as conseqüências e reflexos legais motivados pela crise financeira desencadeada a partir de setembro de 2008 começavam a ser discutidas, abrindo um campo fértil para desenvolvimento de mecanismos de proteção aos investidores e acionistas e para avaliação das condutas dos administradores e controladores de companhias.

Os veículos de comunicação transmitem as opiniões de economias e juristas renomados quanto aos motivos e extensão da crise e existe quase unanimidade na constatação de que se trata de uma crise estrutural do sistema capitalista que irá exigir a revisão de princípios, inclusive do Direito Societário e, até mesmo, a revisão do papel do Estado na intervenção e regulamentação dos mercados.

O crescimento dos mercados consumidores em todo o mundo, aumentou a demanda por produtos industrializados, aumentando, em decorrência, o volume de valores acumulados e o patrimônio de muitas empresas, que passaram a ter atuação globalizada para expansão de seus negócios e aumento de resultados. Esses resultados foram possíveis em razão do desenvolvimento de sistemas tecnológicos que permitem a troca de informações com grande rapidez e aumentam a velocidade das operações comerciais.

O aumento desenfreado do consumo e da oferta de crédito, em algumas economias, criou um cenário econômico que não condizia com a realidade e que começou a desmoronar em meados de 2008. Grandes corporações, instituições financeiras e fundos de investimento que antes acumulavam lucros recordes e ofereciam grandes retornos a seus acionistas e investidores, tiveram seus patrimônios reduzidos drasticamente e até mesmo faliram, exigindo a intervenção estatal para que as conseqüências não contaminassem outras empresas e afetassem, ainda mais, os indivíduos que poderiam perder suas economias e empregos, agravando ainda mais o que hoje se apresenta como a maior recessão mundial desde a Grande Depressão da década de 1930. 
Os mecanismos de controle e instituições que regulam e fiscalizam esse mercado, falharam e não foram suficientes para antever a crise e exigir mudanças no comportamento dos agentes. No entanto, para se evitar um agravamento da crise e evitar maiores prejuízos aos cidadãos comuns, pacotes de ajuda econômica a empresas têm sido aprovados por todo o mundo, em valores astronômicos, que, em um segundo momento, se revelam insuficientes, o que demonstra que ainda não foi possível estimar a totalidade dos prejuízos e de empresas, pessoas e mercados afetados.

Todo esse cenário começa a ser analisado neste momento e as conseqüências e responsabilidades das companhias, seus acionistas e administradores, assim como as perspectivas para análise do comportamento desses últimos, na assunção de riscos e especialmente no cumprimento de seus deveres de diligência, informação e lealdade, destes últimos, para as companhias e seus acionistas ganham a frente dos debates.

Um dos principais focos de análise trata da retomada de padrões éticos de conduta, não apenas na relação dos administradores e acionistas em suas companhias, mas também para com a sociedade em geral, a economia dos países em que atuam, a utilização de recursos naturais, respeito ao meio-ambiente, assumindo assim, um compromisso com as futuras gerações.

Essa situação também irá acarretar, pelo menos no primeiro momento, em uma intervenção maior do Estado na economia, para que sejam apuradas as situações financeiras reais de empresas estratégicas para a segurança do sistema econômico nacional de alguns países. Alguns economistas, inclusive, defendem a nacionalização ou aquisição do controle, de algumas empresas, especialmente bancos, para conferir, neste momento, segurança ao sistema financeiro.

No Brasil, os reflexos da crise já estão sendo sentidos. A CVM editou norma determinando a reapresentação de balanços de algumas empresas, em razão dos enormes prejuízos causados pela utilização de instrumentos financeiros de alto risco, para que os acionistas tenham acesso às informações com relação ao grau de risco e potenciais perdas que as empresas poderão sofrer. 
Da mesma forma, estão sendo noticiadas situações envolvendo acionistas, companhias e administradores, para verificar a responsabilidade pelos grandes prejuízos causados a empresas que antes eram consideradas economicamente saudáveis e que distribuíam grandes valores de dividendos a seus acionistas, agora precisam da ajuda financeira do governo e de bancos, ou da realização de reestruturações societárias para sobreviver.

Em razão disso, poderemos verificar alterações no comportamento de acionistas e investidores brasileiros, tradicionalmente passivos e avessos a recorrer ao Judiciário para intervir nos problemas internos das companhias e também dos administradores, o que irá contribuir para o desenvolvimento da análise e interpretação jurídica dos deveres dos administradores e da administração de companhias e os limites da intervenção judicial na administração das sociedades por ações, tema da presente pesquisa.

No entanto, nessa análise, os princípios gerais que regem o Direito Societário devem prevalecer. Não se pode perder de vista o risco inerente às atividades empresariais, que está diretamente relacionado ao seu retorno. O Judiciário deve se ater a verificar a legalidade das decisões tomadas, que causaram esses prejuízos, observadas as características e riscos que essa atividade impõem e os direitos de acionistas e administradores, que devem ser resguardados, se comprovado que agiram de boa-fé e em cumprimento seus deveres legais. 


\section{RESUMO}

A legislação aplicável às sociedades por ações utiliza conceitos e normas abertas que devem ser interpretadas com base nos princípios que regem as sociedades por ações, considerando, nessa análise, as características específicas da companhia na qual surgiu a controvérsia e as situações que integram e esclarecem a situação controversa levada a conhecimento do Judiciário.

A liberdade dos empresários, na condução de suas atividades, tem fundamento no sistema econômico Brasileiro, conforme princípios da Constituição Federal. No entanto, os interesses sociais protegidos pela Constituição Federal exigem que as empresas, especialmente as sociedades por ações, que agregam características institucionais, estabeleçam limites para a condução das atividades das companhias.

Da mesma forma, a criação de um ente autônomo e dotado de patrimônio próprio, cria uma separação entre o poder de controle e administração dos bens, direitos e obrigações que integram esse patrimônio e os acionistas que contribuíram inicialmente para sua constituição, motivo pelo qual a condução dos negócios empresariais deve sempre buscar atingir os interesses da companhia e os agentes necessários para realização dessas atividades têm deveres e responsabilidades com os demais acionistas e terceiros afetados pela existência da companhia.

Nesse contexto, a atuação do Judiciário se restringe a verificar a ocorrência de atos ilegais de gestão. O Judiciário, no sistema jurídico brasileiro, não podendo interferir no mérito das deliberações, sob pena de infringir o princípio da livre iniciativa e do exercício do poder de controle, que estruturam o sistema legal que regula as sociedades por ações. A responsabilidade dos administradores e controladores que agem de boa-fé nos atos regulares de gestão deve ser preservada em face dos resultados da companhia e os interesses dos demais sócios. 


\begin{abstract}
The applicable legislation pertaining to corporations make use of broad rules and concepts which must be interpreted with basis on the prevailing principles ruling corporations and taking into consideration, in such analysis, the specific characteristics of the company in which the controversy has emerged and also taking into consideration the whole scenario of which the litigious point is an integral part and which may clarify the controversy brought before the Judiciary.
\end{abstract}

The shareholders freedom, while performing their activities, is grounded upon the Brazilian economic system, in accordance with the principles set forth by the Federal Constitution. Notwithstanding, the corporate rights protected by the Constitution require that corporations, accumulating institutional characteristics, set forth limitations for conducting their business activities.

In this sense, the creation of an autonomous body endowed with its own assets, generates a separation by and between the power of control and asset management, rights and obligations which are an integral part of such a property and the shareholders who initially contributed for its constitution; therefore business should be conducted so as to meet the interests of the corporation; and the agents deemed necessary for the fulfillment of such activities have duties and responsibilities before the existing company's remaining shareholders and affected third parties.

In this context, the actions of the Judiciary is restricted to verify the occurrence of illegal acts of management. Under Brazilian legal system, the Judiciary may not interfere on the merit of the proceedings, under penalty of infringing the principle of free initiative and the exercise of power to control, which structure the legal system that governs the corporations. The responsibility of managers and controllers that act in good-faith in the acts regular management must be maintained in view of the results of the company and the interests of other members. 


\section{SINTESI}

La corrente legislazione pertinente a una società per azioni fa uso di norme ampi e aperte, le cui dovranno essere interpretati su i principi prevalenti che disciplinano le società e cosiderando in tale analisi delle caratteristiche specifiche delle società per azioni e anche le situazioni che constituiscono e sono capabilli di chiarire i punti litigiosi proposto dinanzi alla magistratura.

La libertà degli azionisti nel svilupo di le loro attività è bassata su is sistema brasiliano di economia, secondo i principi stabiliti dalla Costituzione Federale. Per quanto, il i diritti tutelati dalla costituzione richieste che le società che possedono qualità istituzionale, principalmente le societa di azioni, hanno limitazioni per dare continuità alle sue attività imprenditoriali.

In questo senso, la creazione di un'entità autonoma dotato dei propri beni, genera una separazione fra il potere di controllo e gestione struttura/attività, i diritti e obblighi che sono parte integrante di questa proprieta e le azzionisti qui hanno creato la società per azioni; questo è il motivo per cui l'impresa dovrebbe essere condotto da soddisfare le desideri della società per azioni e come tale il agenti ritenuti necessari per il titolo di tali attività hanno diritti e responsabilità di fronte al altri azionisti e altri terzi coinvolti a motivo della propria esistenza della società.

In questo contesto, le azioni del potere giudiziario è limitata a verificare la presenza di atti illegali di gestione. Il sistema giudiziario, brasiliano sistema giuridico, e non può interferire sul merito della controversia, sotto pena di violare il principio della libera iniziativa e l'esercizio del potere di controllo, cui la struttura del sistema giuridico che disciplina le società per azioni. La responsabilità dei direttori e controllori che agiscono in buona fede negli atti regolari di gestione deve essere mantenuta in base ai risultati dell'impresa e gli interessi degli altri membri. 


\section{BIBLIOGRAFIA}

As obras incluídas nesta Bibliografia foram citadas ao longo do texto, conforme previsto nas Normas da Associação Brasileira de Normas Técnicas e também serviram de valiosa consulta para a pesquisadora, no desenvolvimento deste trabalho.

- ABRÃO, Nelson. Sociedade por Quotas de Responsabilidade Ltda. $8^{\text {a }}$ edição. São Paulo: Saraiva, 2000.

- ADIERS, Leandro Bittencourt. Demanda Reparatória ajuizada por Acionista em Virtude de Adimplemento Imperfeito. Função e Natureza Jurídica das Demonstrações Financeiras. Caráter Constitutivo das Decisões Assembleares tomadas por Órgãos das Sociedades Anônimas. A Ação Reguladora e Princípios Essenciais Vinculadores de Companhias Abertas com Valores Mobiliários no Mercado de Capitais. Imposições da Ordem Constitucional Econômica. Prazos de Prescrição na Lei das Sociedades Anônimas. Revista de Direito Mercantil, Industrial, Econômico e Financeiro, vol. 129. São Paulo: Malheiros Editores, janeiro-março, 2003.

- ALLEN, William T. Modern Corporate Governance and the Erosion of the Business Judgment Ruel in Delaware Corporate Law. Toronto: Law Research Paper Series, Osgood Hall Law School, York University. Disponível em: <http://ssrn.com/abstractid=1105591 >. Acesso em 01.dez.2008.

- ALVIM, Arruda. Direito privado. São Paulo: Revista dos Tribunais, 2002, vol. 2.

- ANDRADE JR., Attila de Souza Leão. Comentários ao Novo Código Civil. Rio de Janeiro: Forense, 2002, vol. 4.

- ARAUJO, José Francelino (coordenador). Direito Empresarial. Porto Alegre: Sagra Luzzatto Editores, 1998.

- ART, Robert C. Shareholder Rights and Remedies in Close Corporations: Oppression, Fiduciary Duties, and Reasonable Expectations. Iowa City: Journal of Corporation Law, Primavera de 2003, Vol. 28, p. 371 Disponível em: $<$ http://proquest.umi.com/pqdweb?did=358286931\&Fmt=2\&clientId=61611\&RQT $=309 \&$ Vname $=$ PQD $>$. Acesso em 20.out.2008.

- ASCARELLI, Tullio. Panorama de direito comercial. São Paulo: Saraiva, 1947. São Paulo: Saraiva, 1945. . Problemas das Sociedades Anônimas e Direito Comparado.

\section{2.} . Studi in Tema di Contratti. Milano: Dott. A. Giuffrè Editore. 
- BAINBRIDGE, Stephen M. Smith v. Van Gorkom. Los Angeles: UCLA School of Law. Law \& Economics Research Paper Series. Research Paper No. 08-13. Disponível em <http://ssrn.com/abstractid=1130972〉, acesso em 18.nov.2008.

- BARBI, Celso Agrícola. Comentários ao Código de Processo Civil. São Paulo: Forense, 1975.

- BAtAlHA, Wilson de Souza Campos. Direito Processual Societário. $2^{\text {a }}$ edição. Rio de Janeiro: Forense, 1989.

- BERLE, Adolfo A. e MEANS, Gardiner C. A Moderna Sociedade Anônima e a Propriedade Privada. São Paulo: Abril Cultural. 1984.

- BEDAQUE, José Roberto dos Santos. Direito e Processo. Influência do Direito Material sobre o Processo. São Paulo: Malheiros, 1995.

- BIANCHI, Giorgio. Amministrazione e controllo delle nuove società di captali. Metodi alternativi di gestione dopo la riforma del diritto societário. Itália: IPSOA, 2006.

- BILDER, Mary Sarah. The Corporate Origins of the Judicial Review. Boston: Boston College Law School. Legal Studies Research Paper Series. Disponível em: <http://ssrn.com/abstract_id=893894>. Acesso em 01.dez.2008.

- BLACK, Bernard e KRAAKMAN, Reinier. A Self-Enforcing Model of Corporate Law. Cambridge: Harvard Law Review, 1996. Disponível em: <http://ssrn.com/abstract_id=10037>. Acesso em 27.dez.2008.

- _. Strenghtening Brazil's Securities Markets. Stanford Law School, Out.2000. Working Paper No. 205. Disponível em: <http://ssrn.com/abstract_id=247673>. Acesso em 27.dez.2008.

- BOITEUX, Fernando Netto. Responsabilidade Civil do Acionista Controlador e da Sociedade Controladora. Rio de Janeiro: Forense, 1988.

- BONTÁ, Silvana Dalla. Le Impugnazioni delle Delibere del C.D.A. Premesse Storico-Comparatistiche. Trento: Università degli Studi di Trento, 2006.

- BOWERS, Helen M. Fairness Opinions and the Business Judgment Rule. An empirical investigation of target firms' use of fairness opinions. Delaware: Center for Corporate Governance, College of Business and Economics, University of Delaware, Maio, 2001. Disponível em <http://ssrn.com/abstractid=306141>, acesso em 28.nov.2008

- BUlgARELli, Waldírio. Estudos e Pareceres de Direito Empresarial (O Direito das Empresas). São Paulo: Revista dos Tribunais, 1980.

Tribunais, 1983. Questões de Direito Societário. São Paulo: Revista dos 
Revista dos Tribunais, 1989.

Problemas de Direito Empresarial Moderno. São Paulo:

. Regime Jurídico da Proteção às Minorias nas S/A.(De acordo com a reforma da Lei $n^{\circ}$ 6.404/76). Rio de Janeiro: Renovar, 1998.

Atlas, 2000.

. Tratado de Direito Empresarial, $4^{\mathrm{a}}$ edição. São Paulo:

Questão Referente a Livros Societários e Documentos

Relativos à Presença e às Deliberações das Assembléias Gerais - Irregularidades de Menor Monta que não se confundem com a Falsidade nem Justificam a sua Anulação. Revista de Direito Mercantil, Industrial, Econômico e Financeiro, vol. 114. São Paulo: Malheiros Editores, abril-junho, 1999.

- CANTIDIANO, Luiz Leonardo. Direito Societário e Mercado de Capitais. Rio de Janeiro: Renovar, 1996.

- CARMONA, Carlos Alberto. A Arbitragem no Processo Civil Brasileiro. São Paulo: Malheiros Editores, 1993.

- CARNEY, William J. e SHEPHERD, George B. The Mystery of Delaware Law's Continuing Success. Emory School of Law. Law \& Economics Research Paper Series. Research Paper No. 07-17. Disponível em http://papers.ssrn.com/abstract=999477, acesso em 28.nov.2008

- CARVAlHOSA, Modesto. Comentários à Lei de Sociedades Anônimas, $2^{\mathrm{a}}$ edição. São Paulo: Saraiva, 1998, volumes 1 a 4-II.

- Comentários ao Código Civil - Parte Especial, do Direito de Empresa. São Paulo: Saraiva, 2003, vol. 13.

- CENTONZE, Michele. L“Inesistenza" delle Delibere Assembleari di S.P.A. Torino: G. Giappichelli Editore. 2008.

- CHANDER, Anupam. Minorities, Shareholders and Otherwise. New Haven: The Yale Law Journal, out. 2003, vol. 113, p. 119-178. Disponível em $<\mathrm{http} /$ proquest.umi.com/pqdweb?did=463827161\&Fmt=4\&clientId=61611\&RQT = 309\&VName=PQD $>$ Acessado em 20.dez.2004.

- COELHO, Paulo Magalhães da Costa. Controle Jurisdicional da Administração Pública. São Paulo: Saraiva, 2002.

- COLL, Osvaldo Walter. Intervención Judicial de Sociedades. Buenos Aires: Lexis Nexis, 2005.

- COMPARATO, Fábio Konder. Novos ensaios e pareceres de direito empresarial. Rio de Janeiro: Forense. 1981. 
Revista dos Tribunais, 1970.

Aspectos Jurídicos da Macro-Emprêsa. São Paulo:

Paulo: Saraiva. 1990.

- Direito Empresarial: Estudos e Pareceres. São e SALOMÃO FILHO, Calixto. O poder de controle na sociedade anônima. $4^{\text {a }}$ edição. São Paulo: Forense, 2005.

- CONAC, Pierre-Henri, ENRIQUES, Luca e GELTER, Martin. Constraining Dominant Shareholders' Self Dealing: The Legal Framework in France, Germany and Italy. Cambridge: Harvard Law School. John M. Olin Center for Law, Economics and Business. Fellows' Discussion Paper Series No. 18, Julho de 2008. <Disponível em http://www.law.harvard.edu/programs/olin_center>, acesso em 18.nov.2008.

- CORRÊA-LIMA, Osmar Brina, Sociedade Anônima. 2a Edição. Belo Horizonte: Del Rey, 2003.

- COZIAN, Maurice, VIANDIER, Alain. Droit des Sociétés. 9a Edição. Paris: Libraire de la Cour de Cassation, 1996.

- CRISTIANO, Romano. O Direito de Empresa à Luz do Novo Código Civil. $2^{\text {a }}$ Edição. São Paulo: Editora Renovar, 2003.

- CUNHA, Rodrigo Ferraz Pimenta da. Estrutura de Interesses nas Sociedades Anônimas - Hierarquia e Conflitos. São Paulo: Quartier Latin, 2007.

- CUNHA, Luciana Gross, CUNHA, Alexandre Santos, SCABIN, Flávia, MACÁRIO, Mariana, ISSA, Marcelo Issa. O Sistema de Justiça Brasileiro, a Produção de Informações e sua Utilização (Relatório de pesquisa). São Paulo: Cadernos Direito GV, $\mathrm{n}^{0}$ 4, março de 2005. Disponível em <http://www.direitogv.com.br/interna.aspx?PagId=HTKCNKWI\&IDCategory=4\&I DSubCategory=29>, acesso em 25.jan.2008.

- DALlARI, Dalmo de Abreu. O Poder dos Juízes. $3{ }^{\text {a }}$ Edição. São Paulo: Saraiva, 2007.

- DI SARNO NETO, Andrea, DAUD, Felipe Taufik, ANDRADE, CURY, Maria Fernanda Calado de Aguiar Ribeiro, PAIVA, Mariana Monte Alegre de, CUNHA, Luciana Gross, PRADO, Viviane Muller. Poder Judiciário e Desenvolvimento do Mercado de Valores Mobiliários Brasileiro. São Paulo: Saraiva, 2008.

- EIZIRIK, Nelson. Aspectos Modernos do Direito Societário. Rio de Janeiro: Renovar, 1992.

BASTOS, Aurélio Wander. $O$ Poder Judiciário $e$ a Jusrisprudência sobre Sociedades Anônimas e Instituições Financeiras. Rio de Janeiro: IBMEC, 1980. 
- ENRIQUES, Luca. Off the Books, But on the Record: Evidence from Italy on the Relevance of Judges to the Quality of Corporate Law. Bolonha. Disponível em $\langle$ http://ssrn.com/abstractid=300573 $>$, acesso em 27.nov.2008.

. Do Corporate Law Judges Matter? Some Evidence from Milan. European Business Organization Law Review 3: 765-821. Disponível em <http://ssrn.com/abstractid=442320>, acesso em 27.nov.2008.

. Scelte pubbliche e interessi particolari nella riforma delle società di capitali. Em fase depublicação no Mercato Concorrenza Regole, 2005, n. 1. Disponível em <http://ssrn.com/abstractid=701141>, acesso em 27.nov.2008.

- FERRAZ JR., Tercio Sampaio. Introdução ao Estudo do Direito: Técnica, Decisão, Dominação. São Paulo: Atlas, 1990.

- FERREIRA, Waldemar. O Direito Insurreicional do Acionista. São Paulo: Revista dos Tribunais, 1939. Tratado de Direito Comercial - O Estatuto da Sociedade de Pessoas. São Paulo: Saraiva, 1961, vol. 3.

Tratado de Direito Comercial - O Estatuto da Sociedade por Ações. São Paulo: Saraiva, 1961, vol. 4.

- FRANÇA, Erasmo Valladão e Novaes. Invalidade das Deliberações de Assembléias das S/A. São Paulo: Malheiros Editores, 1999.

- Anulação de Assembléia de Transformação

de Sociedade Anônima. Revista de Direito Mercantil, Industrial, Econômico e Financeiro, vol. 119. São Paulo: Malheiros Editores, julho-setembro, 2000.

- Legitimação do Sócio da Sociedade

Controladora para Pleitear a Anulação da Assembléia da Controlada Subsidiária Integral. Revista de Direito Mercantil, Industrial, Econômico e Financeiro, vol. 129. São Paulo: Malheiros Editores, janeiro-março, 2003.

S.A, São Paulo: Malheiros, 1993 . Conflito de Interesses nas Assembléias de

e PEREIRA NETO, Edmur A. Nunes. Sociedade Anônima - Fraude à Lei - Alteração dos Estatutos com o Intuito de Evitar que os Acionistas Preferencialistas adquiram o Direito de Voto às Vésperas de Completar o Terceiro Exercício Social sem o Pagamento de Dividendos - Abuso do Poder de Controle. Revista de Direito Mercantil, Industrial, Econômico e Financeiro, vol. 133. São Paulo: Malheiros Editores, janeiro-março, 2004.

- FRONTINI, Paulo Salvador. Sociedade por Quotas. Revista de Direito Mercantil, Industrial, Econômico e Financeiro, vol. 114. São Paulo: Revista dos Tribunais, abril-junho 1999. 
A Atividade Negocial e seus Pressupostos Econômicos

e Políticos, Revista de Direito Mercantil, Industrial, Econômico e Financeiro, vol. 18. São Paulo: Revista dos Tribunais, Ano XIV, Nova Série, 1975.

- GAlgANO, Francesco. Diritto Commerciale, Le Società. $3^{\mathrm{a}}$ edição. Bologna: Zanichelli, s/d.

- GAMBA, Cinzia. Diritto Societário e Ruolo del Giudice. Padova: CEDAM, 2008.

- GILSON, Ronald J. e GORDON, Jeffey N. Controlling Controlling Shareholders. Nova Iorque: Columbia Law School. The Center for Law and Economic Studies. Working Paper No. 228, Junho de 2003. Disponível em http://ssrn.com/abstract_id=417181. Acesso em 01.dez.2008.

- GOMES, Orlando. Contratos. 18 a edição. Rio de Janeiro: Editora Forense, 1999.

- GRAU, Eros. O Direito Posto e o Direito Pressuposto. $5^{\text {a }}$ edição. São Paulo: Malheiros Editores, 2003.

- HALPERIN, Isaac e OTAEGUI, Julio C. Sociedades Anônimas. $2^{a}$ edição. Buenos Aires: Ediciones Depalma, 1998.

- _ _ Sociedades Anónimas, Examen Crítico del Decreto-Ley 19.550. $2^{a}$ edição. Buenos Aires: Ediciones Depalma, 1978.

- KELSEN, Hans. Teoria Pura do Direito. 2a edição. São Paulo: Livraria Martins Fontes Editora, 1987.

- $\quad$ LAMY FILHO, Alfredo e PEREIRA, José Luiz Bulhões. A lei das S.A.. $3^{a}$ edição. Rio de Janeiro: Renovar, 1997, vol. 1.

Rio de Janeiro: Renovar, 1996, vol. 2. A lei das S.A.. $2^{a}$ edição. . A Reforma da Lei de Sociedades Anônimas. Revista de Direito Mercantil, Industrial, Econômico e Financeiro, $n^{\circ}$ 07. São Paulo: Revista dos Tribunais, Ano XI, Nova Série, 1972.

- LANFRANCHI, Lucio e CARRATTA, Antonio. Davanti al giudice. Studi sul processo societário. Torino: G. Giappichelli Editore, 2005.

- LAURINI, Giancarlo. Poteri e Responsabilità nella Formazione delle Delibere Assembleari. Napoli: Edizioni Scientifiche Italiane, 2003.

- LEÃES, Luiz Gastão Paes de Barros. Do Direito do Acionista ao Dividendo. São Paulo: Oficinas da Editora Obelisco, 1969.

- $\quad$ LOBO, Jorge Joaquim. Sociedades Limitadas. Rio de Janeiro: Forense, 2004, vol. 1. 
- LUCCA, Newton. O Direito de Recesso no Direito Brasileiro e na Legislação Comparada, Revista de Direito Mercantil, Industrial, Econômico e Financeiro, vol. 114. São Paulo: Revista dos Tribunais, abril/junho 1994.

- LUCENA, José Waldecy. Das sociedades por quotas de responsabilidade limitada. Rio de Janeiro: Renovar, 1996.

- MARTINS, Fran. Curso de Direito Comercial. $8^{\text {a }}$ edição, Rio de Janeiro: Forense, 1994.

\section{tomo 2.}

. Comentários à lei das S.A. Rio de Janeiro: Forense, 1978, vol. 2, . Novos estudos de direito societário. São Paulo: Saraiva, 1988.

- MARTINS, Ives Gandra da Silva e VIDIGAL, Geraldo de Camargo. Comentários à Lei das Sociedades por Ações. $1^{\mathrm{a}}$ edição. Rio de Janeiro: Forense Universitária, 1999.

- MEIRELlES, Hely Lopes. Direito Administrativo Brasileiro. $18^{\text {a }}$ edição, atualizada por Eurico de Andrade Azevedo, Délcio Balestero Aleixo e José Emmanuel Burle Filho. São Paulo: Malheiros, 1990.

- MENDONÇA, José Xavier Carvalho de. Tratado de Direito Comercial Brasileiro, volumes II, III, IV e V. Revista por Achilles Bevilaqua e Roberto Carvalho de Mendonça. $2^{a}$ edição. Rio de Janeiro: Livraria Editora Freitas Bastos, 1933.

- MESSINA, Paulo de Lorenzo e FORGIONI, Paula A. Sociedades por Ações. Jurisprudência, Casos e Comentários. São Paulo: Revista dos Tribunais, 1999.

- MILLER, Sandra K.How Should U.K. and U.S. Minority Shareholder remedies for unfairly prejudicial or oppressive conduct be reformed? Austin: American Business Law Journal, Summer, 1999. Vol. 36. Disponível em http://proquest.umi.com/pqdweb?did=45397456\&Fmt=2\&clientId=61611\&RQT=3 09\&VName=PQD. Acesso em 20.out.2008.

- MIRANDA, Pontes de, Tratado de Direito Privado. $2^{\text {a }}$ edição. Rio de Janeiro: Borsoi. Tomo 50, 1965.

- MOLL, Douglas K. Shareholder Oppression \& Dividend Policy in the Close Corporation. Washington: Washington \& Lee Law Review, 2003. Disponível em: <http: //ssrn.com/abstract=437162>. Acesso em 20.out.2008.

- NICHOLSON, Brent. The Fiduciary Duty of Close Corporation Shareholders: a call for legislation. American Business Law Journal, nov. 1992, vol. 30, p. 513-536. Disponível em: <http:http://proquest.umi.com/> Electronic Collection: A13492250. Acesso em 20.out.2008.

- O'NEAL, F. Hodge, THOMPSON, Robert B. O'Nea's Close Corporations. $3^{\mathrm{a}}$ Edição. Illinois: Callaghan \& Company, 1986 e 1989, Vols. 1 e 2. 
- PAES, P.R. Tavares. Direito Empresarial, Estudo e Pareceres. 2 $2^{\text {a }}$ edição. São Paulo: Atlas, 1995.

- PENTEADO, Mauro Rodrigues. Eleição de administradores em sociedades filiadas a grupos societários. Revista de Direito Mercantil Industrial Econômico e Financeiro, São Paulo, v. 40, 1980.

São Paulo: Saraiva, 1988. Aumentos de Capital das Sociedades Anônimas. Junta Comercial: Deliberação de Assembléia Geral e Atentado. Revista de Direito Mercantil Industrial Econômico e Financeiro, São Paulo, v. 72, 1988.

- Sociedade Anônima. Acionista Controlador. Revista de Direito Mercantil Industrial Econômico e Financeiro, São Paulo, v. 83, 1991. . Dissolução e Liquidação de Sociedades. $2^{\mathrm{a}}$ edição. Distrito Federal: Livraria e Editora Brasília Jurídica, 2000.

- Empresa Contemporânea e Direito Societário. Poder de Controle e Grupos de Sociedade, RDM. Revista de Derecho del MERCOSUR, v. 133, p. 301-302, 2004.

- PISTOR, Katharina e XU, Chenggang. Fiduciary Duty in Transitional Civil Law Jurisdictions Lessons from the Incomplete Law Theory..ECGI - Law Working Paper n 01/2002. Disponível em: http://ssrn.com/abstract id=343480>, acesso em 25.jan.2008.

Law Enforcement under Incomplete Law: Theory and Evidence from Financial Market Regulation. Londres: Suntory and Toyota Internacional Centres for Economics and Related Disciplines - Theoretical Economics Discussion Paper, dezembro de 2002. Disponível em: <http://ssrn.com/abstract_id=396141>, acesso em 12.dez.2008.

. Incomplete Law - A Conceptual and Analytical Framework and its Application to the Evolution of Financial Market Regulation. Journal of International Law and Politics, Vol. 35, No. 4, pp. 931-1013, 2003. <Disponível em: http://ssrn.com/abstract $\mathrm{id}=310588>$, acesso em 25.jan. 2008.

Fiduciary Duty in Transitional Civil Law Jurisdictions: Lessons from the Incomplete Law Theory. European Corporate Governance Institute, Outubro, 2002. <Disponível em: <http://ssrn.com/abstract id=343480>, acesso em 25.jan.2008.

- PORZIO, Mario. L'Estinzione della Società per Azioni. Napoli: Cada Editrice Dott. Eugenio Jovene, 1959. 
- PRADO, Viviane Muller e BURANELLI, Vinícius Correa. Relatório da pesquisa de jurisprudência sobre Direito Societário e mercado de capitais no Tribunal de justiça de São Paulo (Relatórios de Pesquisa). São Paulo: Cadernos Direito GV, $\mathrm{n}^{\mathrm{o}}$ 9, janeiro de 2006. Disponível em <http://www.direitogv.com.br/interna.aspx ?PagId=HTKCNKWI\&IDCategory=4\&I DSubCategory=68>, acesso em 25.jan.2008.

- QUATRARO, Bartolomeo e TOSI, Emilio. Il Controllo Giudiziario delle Società: Rassegna Critica di Dottrina e Giurisprudenza sull'art. 2409 C.C. $2^{\mathrm{a}}$ Edição ampliada. Milão: Giuffrè Editore, 1997.

- RAMSEYER, J. Mark. Not-so-ordinary Judges in Ordinary Courts: Teaching Jordan v. Duff \& Phelps. Cambridge: Harvard Law School. John M. Olin Center for Law, Economics and Business, 08/2006. Disponível em: http://ssrn.com/abstract id=927862, acesso em 01.dez.2008.

- REALE, Miguel, Fontes e Modelos do Direito. Para um novo Paradigma Hermenêutico. $1^{\mathrm{a}}$ Edição, $3^{\mathrm{a}}$ Tiragem. São Paulo: Saraiva, 2002.

Paulo: Saraiva, 2007. Lições Preliminares de Direito. $27^{\mathrm{a}}$ Edição, $7^{\mathrm{a}}$ Tiragem. São

- REQUIÃO, Rubens. Curso de Direito Comercial. 21 ${ }^{\mathrm{a}}$ Edição. São Paulo: Saraiva, 1993, vol. 1.

2003, vol. 2.

. Curso de Direito Comercial. 23 ${ }^{\text {a }}$ Edição. São Paulo: Saraiva, . A Sociedade Anônima como "Instituição". Revista de Direito

Mercantil, Industrial, Econômico e Financeiro, vol. 18. São Paulo: Revista dos Tribunais, Ano XIV, Nova Série, 1975.

- RIBEIRO, José Horácio Halfeld Rezende. Abuso do Direito. Contornos de Direito Material e Processual. São Paulo: Revista do Advogado, AASP, Julho de 2008, ${ }^{\circ}$ 98.

- RODRIGUES, Silvio. Direito Civil: Responsabilidade Civil. São Paulo: Saraiva, 2002.

- SAlOMÃo FILHO, Calixto. O Novo Direito Societário. 2a Edição. São Paulo: Malheiros Editores Ltda., 2002.

Sociedade Anônima: Interesse Público e Privado.

Revista de Direito Mercantil, Industrial, Econômico e Financeiro, vol. 127. São Paulo: Malheiros Editores, julho-setembro, 2002.

- SANTOS, Jurandir dos. Manual das Assembléias Gerais nas Sociedades Anônimas. São Paulo: Editora Saraiva, 1994. 
- SCIUTO, Maurizio. La "Mancanza dell'atto Costitutivo" di Societá per Azioni. Padova: Cedam, 2000.

- SILVA, Alexandre Couto. A Regra do Julgamento do Negócio: Business Judgment Rule. Belo Horizonte: Faculdade de Direito da UFMG, 2005. Tese apresentada ao Curso de Doutorado da Faculdade de Direito da Universidade Federal de Minas Gerais, ainda não publicada.

- SIMIONATO, Frederico Augusto Monte. Sociedades Anônimas \& Interesse Social. Curitiba: Juruá, 2004.

- SLERCA JR., Mário. Controle Judicial dos Atos Empresariais. Atos Relativos à Orientação dos Negócios Sociais e ao Aproveitamento de Oportunidades Comerciais - As Primeiras Decisões da Justiça Brasileira. Revista dos Tribunais, ano 78, volume 640. São Paulo: Revista dos Tribunais, fevereiro, 1989.

- STASSANO, Giuseppe. Atti e Delibere delle Societá di Capitali. Torino: G. Giappichelli Editore, 2006.

- STOU, Lynn A. In Praise of Procedure: an Economic and Behavioral Defense of Smith v. Van Gorkom and the Business Judgment Rule. Los Angeles: University of California School of Law. Research Paper Series. Research Paper No. 01-21. <Disponível em http://papers.ssrn.com/abstract_id=290938>, acesso em 28.nov.2008.

- SZTAJN, Rachel. Contrato de Sociedade e Formas Societárias. São Paulo: Saraiva, 1989.

- O direito de recesso nas sociedades comerciais. Revista de Direito Mercantil, Industrial, Econômico e Financeiro, vol. 71. São Paulo: Revista dos Tribunais, jul/set 1988.

São Paulo: Atlas, 2004. . Teoria Jurídica da Empresa. Atividade Empresária e Mercados.

- TEIXEIRA, Egberto Lacerda. Das sociedades por quotas de responsabilidade limitada. São Paulo: Max Limonad, 1956.

GUERREIRO, José Alexandre Tavares. Sociedades

Anônimas. São Paulo: José Bushastsky, 1979, vol. 2.

- TERRUSI, Francesco. L'Invalidità delle Delibere Assembleari Della SPA. Giuffrè Editore. Milão: 2007.

- THOMPSON, Robert T. Mapping Judicial Review: Sinclair Oil v. Levien. Vanderbilt University Law School Public Law and Legal Theory. Working Paper No. 08-36. Disponível em http://ssrn.com/abstract_id=1161299.

- VALVERDE, Trajano de Miranda. Sociedades por Ações. $3^{\mathrm{a}}$ Edição. Rio de Janeiro: Editora Forense, 1959, vols. 1 e 3. 
- VENOSA, Sílvio de Salvo. Teoria Geral das Obrigações e Teoria Geral dos Contratos. São Paulo: Atlas, 2002.

- VITRÓ, Vincenzo. Procedimento Camerali, Omologa e Nullitá Delle Società per Azioni. Milano: Giuffrè Editore, 1998.

- WALD, Arnoldo. Efeitos da Falta de Arquivamento na Junta Comercial dos Atos de Deliberação de Cisão de Sociedades em Virtude de Decisões Judiciais. Revista de Direito Mercantil, Industrial, Econômico e Financeiro, vol. 121. São Paulo: Malheiros Editores, janeiro-março, 2001.

Saraiva, 2009.

Direito Civil, Introdução e Parte Geral, $11^{a}$ edição. São Paulo:

- ZANINI, Carlos Klein, A Doutrina dos "Fiduciary Duties" no Direito NorteAmericano e a Tutela das Sociedades e Acionistas Minoritários frente aos Administradores das Sociedades Anônimas. Revista de Direito Mercantil, Industrial, Econômico e Financeiro, vol. 109. São Paulo: Revista dos Tribunais, jan/mar 1998. 